$$
\begin{aligned}
& \text { UNIVERSIDADE DE SÃO PAULO } \\
& \text { INSTITUTO DE GEOCIÊNCIAS }
\end{aligned}
$$

\title{
MONOGRAFIA DO AQUIFERO JANDAÍRA DA BACIA POTIGUAR
}

\author{
Volume 1 - Texto
}

Gildo Mistretta

Orientador: Prof. Dr. André Davino

Área de Concentrạãão: Geologia Geral e de Aplicação 
UNIVERSIDADE DE SÃO PAULO

INSTITUTO DE GEOCIÊNCIAS

\section{MONOGRAFIA DO AQUIFERO JANDAİRA DA BACIA POTIGUAR}

Gildo Mistretta

Orientador: Prof. Dr. André Davino

DISSERTAC̣ÃO DE MESTRADO

COMISSÃO EXAMINADORA

nome

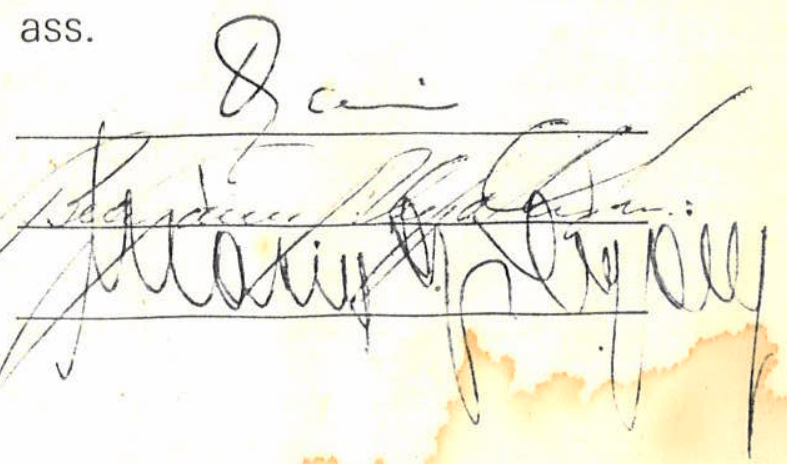

São Paulo 


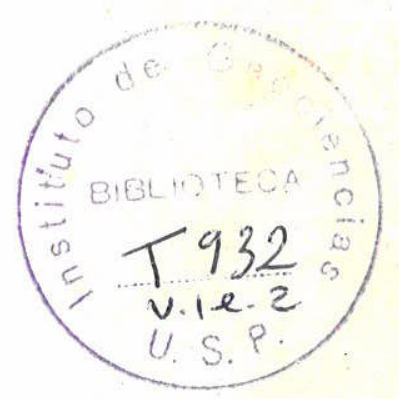

... O Senhor respondeu a Moisés:

"Passa adiante do povo, leva con tigo alguns dos anciãos de Is rael, toma na mão tua vara com que feriste o Nilo, e vai. Eis que estarei ali diante de ti sobre o rochedo do monte Horeb: ferirás o rochedo e a água jor rará dele: assim o povo podera beber".

(Exodo 17: 5 e 6) 
A

Salvador (in memoriam) e Francisca, meus pais; Maria Estela, minha espo sa, e Guilherme e Mônica, meus fi lhos, dedico esta monografia. 
AGRADECIMENTOS

o autor externa pública e reverentemente a sua profunda gratidão às pessoas e instituições cuja colaboração e conjuga ção de esforços tornou possível a elaboração da presente mono grafia.

Ao Professor Doutor André Davino agradeço a orientação du rante o curso de pós-graduação e desenvolvimento das atividades envolvidas na elaboração desta Dissertação.

Ao Professor Doutor Aldo da Cunha Rebouças agradeço as sü gestões apresentadas por ocasião do início das pesquisas.

Ao Professor Doutor Benjamim Bley de Brito Neves agradeço as pro veitosas sugestões apresentadas, na qualidade de relator de pá recer sobre a Dissertação.

Especiais agradecimentos são dirigidos aos. colegas do Agru pamento de Hidrogeologia do IPT, Geólogo José Luiz Albuquerque Filho e Geólogo Sergio Gouveia de Azevedo que, num gesto de ver dadeiro altruísmo, assumiram a título de real colaboração, como se fossem suas as responsabilidades de muitas atividades duran te o desenvolvimento dos trabalhos.

Ao Geólogo Dr. Alcides Frangipani e Geólogo José Pompeu dos Santos sou grato pelas proveitosas discussões tēcnicas so bre os temas desenvolvidos.

Aos colegas também do agrupamento de Hidrogeologia, Geólo go João Alberto Bottura e Geólogo Júlio Cesar Arantes perroni apresento meus agradecimentos pela colaboração prestada.

Ao estudante Sr. Urandi Moreno Pires Correia, assistente aluno de Geologia no Agrupamento de Hidrogeologia sou grato pe lo auxílio diligente ao autor, prestado em muitas atividades bạ sicas de coleta e tratamento de dados.

Aos tēcnicos Maurício Acióly Ribeiro Junior, otávio Mar tins e Vitōrio Celso populin agradeço a colaboração prestada tambēm na coleta e preparação de documentos básicos para o tra tamento de dados.

Aos colegas do Agrupamento de Geomatemática, Engenheiro de Minas Genis Garcia Pereira Junior, Estatísticos Lucia de Fātima Silveira Dozzi e Hermes Chaves Filho e Físico Mārio otávio Costa, e também ao Estatístico José Alberto Quintanilha do Agru 
pamento de Recursos Minerais, agradeço a dedicação no desenvol vimento e aplicação de programas computacionais para tratanento dos dados.

Ao Contabilista Josē Roberto Pissiguelli sou grato pelas considerações feitas no concernente à avaliação de custos de prođução de ägua.

Aos colegas do Agrupamento de Geologia Geral, Geölogo Car los Alberto Bistrichi e Geölogo Dr. Celso Dal Ré Carneiro pelas. inestimáveis sugestões apresentadas.

Ao colega Geólogo Antonio Celso de Oliveira Braga, do Agru pamento de Geofísica, fico agradecido pelas atenções nas dis cussões tēcnicas na ärea de Geofísica.

Especiais agradecimentos manifesto tambëm à srta. Aradi Jecira da Cruz e Sra. Magali Caracciolo Martins que incansāveis e pacientes, com prestimosa datilografia transformaram desapare lhados manuscritos em um texto de modulada e atraente escrita.

Ao Sr. Francisco Carlos Ribeiro, Sr. Waldyr Dantas Cortez, Sr. Jayme Vergilio e ao Sr. Aluízio Souza Frota, agradeço o cui dadoso trabalho de preparação das ilustrações.

Ao Sr. Antonio Beraldo Filho fico agradecido pela disposi ção e presteza na reprodução dos documentos.

Aos bibliotecários Sra. Márcia Regina Migliorato Saad, sra. Maria de Lourdes Assis Santos e Sr. Manoel Roque Galvão agrade ço a presteza na recuperação bibliográfica sobre a qual se refe renciou o autor em suas pesquisas; à Srta. Maria Inez do Prado e Srta. Maria Solange de Oliveira Pereira pela revisão feita na normalização das referências bibliográficas e à sra. Lourdes Mangiollo Mioto, pelo empenho para a estruturação e montagem fi nal da monografia.

A COMPANHIA DE DESENVOLVIMENTO DE RECURSOS MINERAIS DO RIO GRANDE DO NORTE-CDM/RN agradeço o fornecimento de dados e infor mações sobre poços tubulares, ensaios de bombeamento e laudos de análises físico-químicas de ägua de poços.

A SONGEO-Sondagens geológicas Ltda. de Natal, sou grato pe lo fornecimento de dados e informações sobre poços tubulares.

AO INSTITUTO DE PESQUISAS TECNOLOGICAS DO ESTADO DE SÃO PAULO-IPT através da Diretoria da Divisão de Minas e Geologia Aplicada, na pessoa do seu Diretor, Geölogo Ricardo Fernandes 
da silva, sou grato pelo ilimitado apoio institucional recebido.

Aqueles que, no anonimato da infra-estrutura contribuiram para que eu pudesse levar a bom termo o compromisso assumido, expresso ainda meus agradecimentos.

- autor 
SUMÁRIO

VOLUME 1

DEDICATÓRIA

AGRADECIMENTOS

ABSTRACT

RESUMO

ILUSTRAÇÕES

1 INTRODUÇÃO $\ldots \ldots \ldots \ldots \ldots \ldots \ldots \ldots \ldots \ldots \ldots \ldots \ldots \ldots \ldots$

1.1 o contexto hidrogeológico da Bacia Potiguar ...... 2

1.2 Objetivos da Monografia do Aquifero Jandaira .... 3

1.3 Metodologia Geral ..................... 3

2 BREVE HISTORICO DOS ESTUDOS HIDROGEOLOGICOS NA BACIA PO

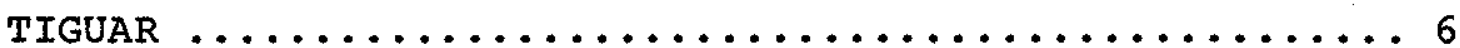

3 FISIOGRAFIA DA BACIA POTIGUAR $\ldots \ldots \ldots \ldots \ldots \ldots \ldots \ldots$

3.1 Geomorfologia $\ldots \ldots \ldots \ldots \ldots \ldots \ldots \ldots \ldots \ldots \ldots \ldots \ldots \ldots$

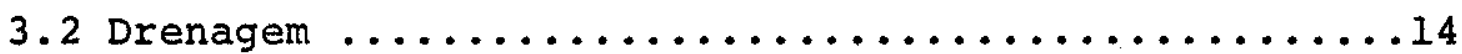

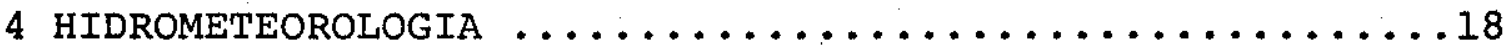

4.1 Introdução $\ldots \ldots \ldots \ldots \ldots \ldots \ldots \ldots \ldots \ldots \ldots \ldots \ldots \ldots \ldots$

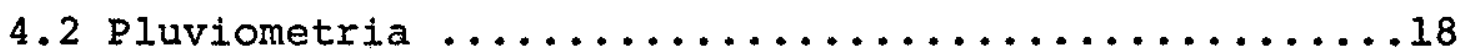

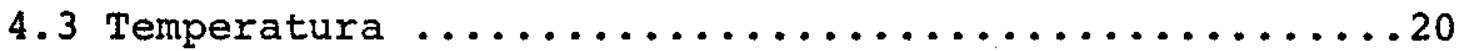

4.4 Insolação .......................... 20

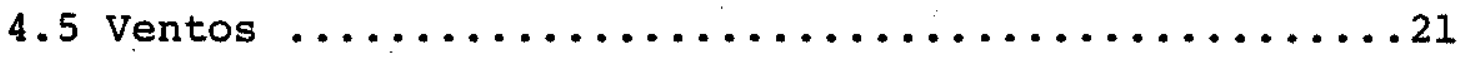

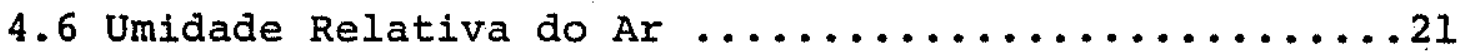

4.7 Evaporação e Evapotranspiração ............... 22

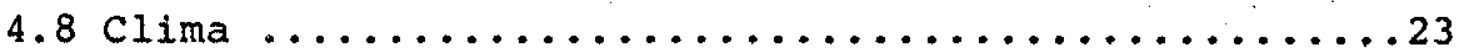


5 SINTESE GEOLOGICA DA BACIA POTIGUAR ............... 27

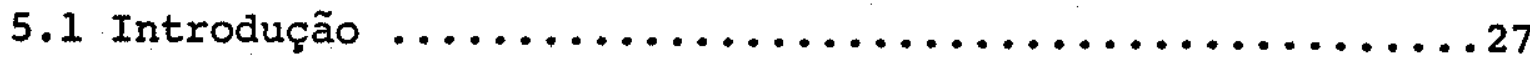

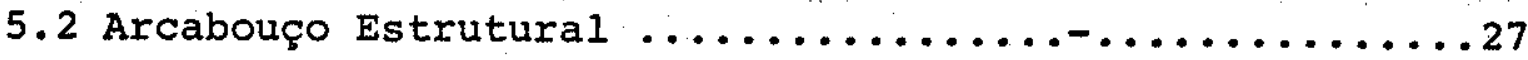

5.3 Litoestratigrafia ...........................

5.3 .1 Formação Pendência ..........................

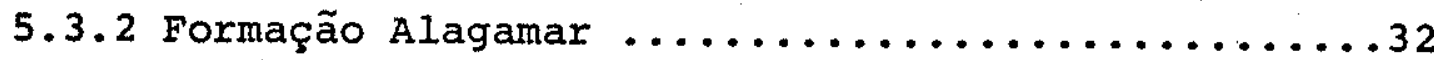

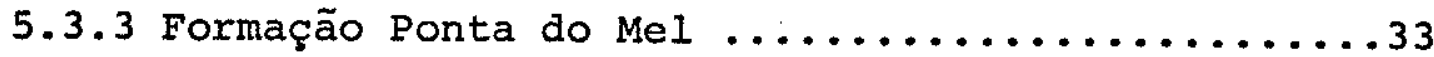

5.3.4 Formações Ubarana, Guamarē e Tibau ...........34

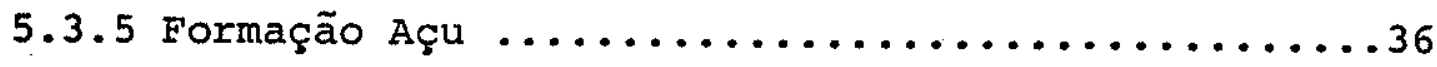

5.3 .6 Formação Jandaira ... . . . . . . . . . . . . . 37

5.3 .7 Formação Macau ......................47

5.3 .8 Grupo Barreiras (Terciärio) ...............48

5.3 .8 .1 Introdução .................48

5.3.8.2 Unidade inferior (Formação Serra do Mar tins $\ldots \ldots \ldots \ldots \ldots \ldots \ldots \ldots \ldots \ldots \ldots \ldots$

5.3.8.3 Unidade média (Formação Guararapes) ... .449

5.3.8.4 Unidade Superior (Formação Macaíba) ...550

5.3.8.5 Ambiente deposicional e idade do grupo Barreiras ...................... 50

5.3.9 Aluviões, Praias e Dunas (Quaternārio) .......5I

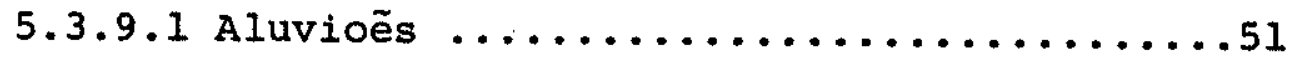

5.3 .9 .2 Praias $e$ dunas ................ 52

6 EXPLORAÇÃo Do AQUIFERO JANDAIRA ... . . . . . . . . . . . 54

6.1 Introdução ............................ 54

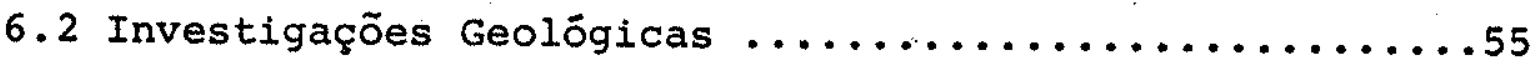

6.3 Investigações Geofísicas ................... . . . . 
6.3 .1 Sondagens Geofisicas ................... 55

6.3 .2 Perfilagens Geofísicas ................64

6.3 .3 Isötopos ambientais ................66

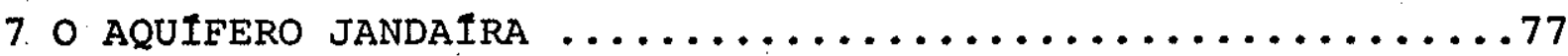

7.1 Caracteristicas Dimensionais .................. 77

7.2 Caracteristicas das camadas semi-confinantes ........79

7.3 Características hidrodinâmicas ...............80

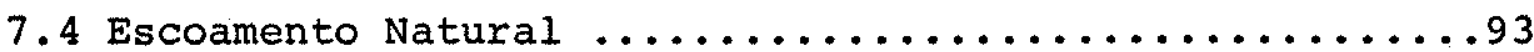

7.5 Interconexões Hidrăulicas do Aquifero Janđaíra .....101

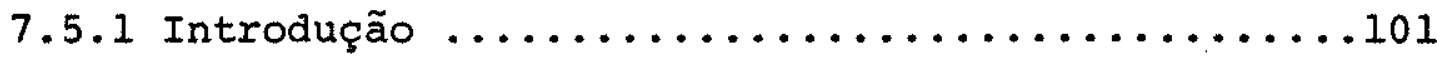

7.5.2 Interconexoẽs hidrăulicas entre os Aquíferos Jan

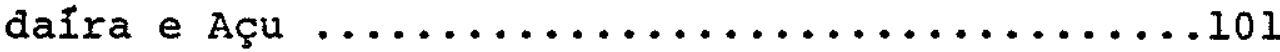

7.5.3 Interconexoẽs hidrăulicas entre os Aquiferos Jandaîra e Dunas-Barreiras .......................

7.6 Posição da Interface Agua doce/salgada ... . . . . . . . 104

7.7 Balanço Hidarıco do Aquifero Jandaịra . . . . . . . . . 107

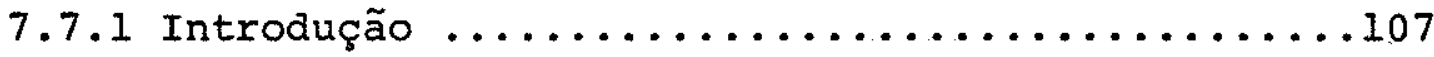

7.7.2 Descarga pelos exutórios naturais do aquífero

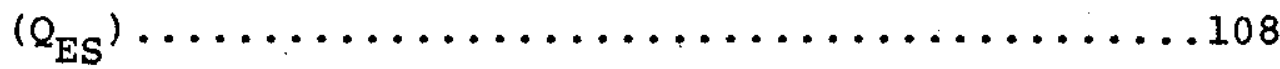

7.7.3 Descarga por drenança para o aquífero Açu

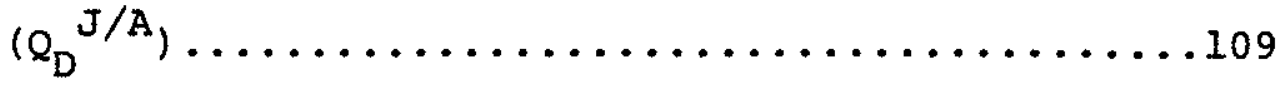

7.7.4 Descarga por explotação atravēs de bombeamento

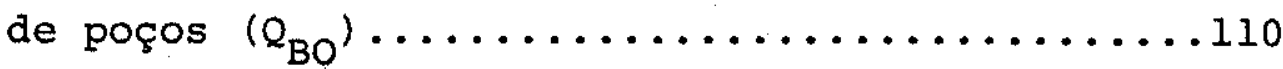

7.7.5 Recarga por drenança do Aquifero Açu para o Aquifero Jandaira $\left(Q_{D}^{A / J}\right) \ldots \ldots \ldots \ldots \ldots \ldots \ldots \ldots \ldots \ldots \ldots \ldots$

7.7.6 Recarga por drenança do sistema aquifero DunasBarreiras para o Aquifero Jandaira $\left(Q_{D}{ }^{B / J}\right) \ldots \ldots 112$ 
7.7.7 Recarga através da infiltração de āguas plü

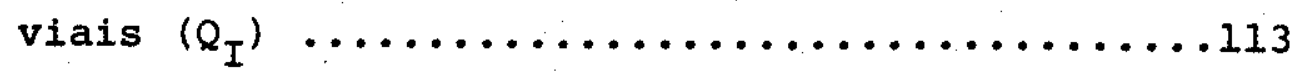

7.8 Avaliação das reservas do Aquífero Jandaíra . . . . . .114 7.8 .1 Introdução ........................ 114

7.8.2 Reservas permanentes e reservas reguladoras....114 7.8.3 Renovação das reservas do Aquífero Jandaíra... 115 7.8.4 Recursos explotāveis do Aquifero Jandaira . . . 116 8. HIDROQUIMICA DO AQUIFERO JANDAIRA . . . . . . . . . . . . 119

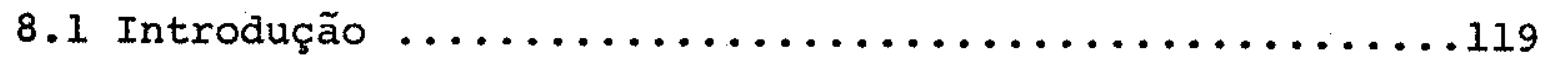

8.2 Caracterização hidroquímica do Aquífero Jandaira ....121 8.3 Classificação das Aguas do Aquífero Jandaira . . . . . 148

8.4 Comportamento espacial das caracteristicas químicas

e físico-químicas das äguas do Aquifero Jandaíra . . .156

8.4.1 Mapa de Total de Sólidos Dissolvidos (TSD) . . . 157

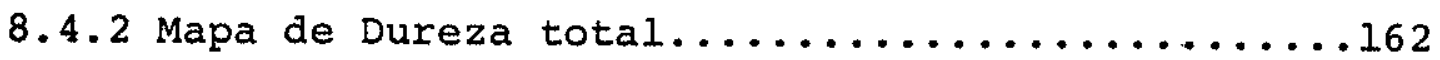

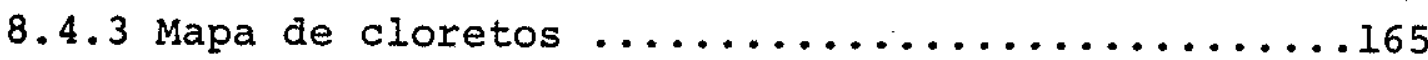

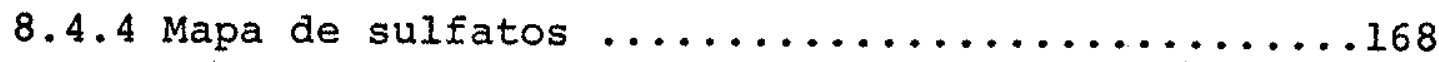

8.4.5 Mapa de Indices de Troca de Bases.(ITB) ....... 169

8.4.6 Mapa de Indices de Estabilidade do carbonato de cálcio (IE) ...........................

8.4.7 Mapa de diagramas de stiff ..............172

8.5 Qualidade das äguas do Aquifero Jandaira ... . . . . . 173

8.5 .1 Introdução ......................173

8.5.2 Adequação para consumo humano ............173

8.5.3 Adequação para consumo agropecuário ... . . . . 179

8.5.3.1 Adequação para consumo agrícola .....179

8.5.3.2 Ạdequação para consumo animal .......183

8.5.4 Adequação para consumo industrial ..........184 
9 SITUAÇÃO ATUAL DA CAPTAÇÃO NO AQUIFERO JANDAIRA ....... 187

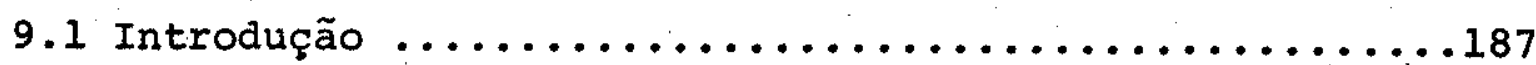

9.2 Evolução das captações no aquífero Jandaíra . . . . . . 187

9.3 Caracteristicas construtivas dos poços tubulares.... 192

9.4 Equipamentos de bombeamento ..................193

9.5 Estado atual dos poços tubulares ................193

9.6 Volume de äguas explotadas . . . . . . . . . . . . . 195

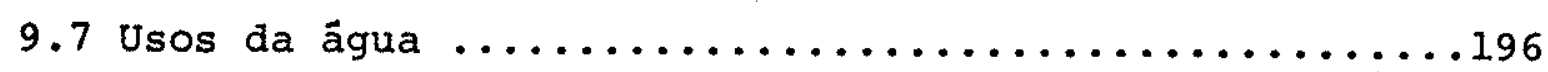

10 CUSTO DE PRODUÇÃO DE AGUA SUBTERRANEA DO AQUIFERO JAN

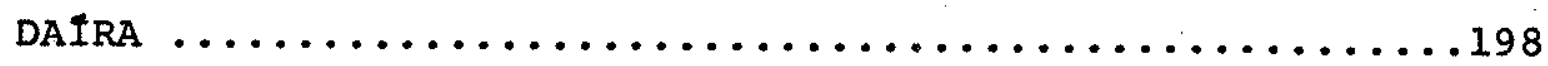

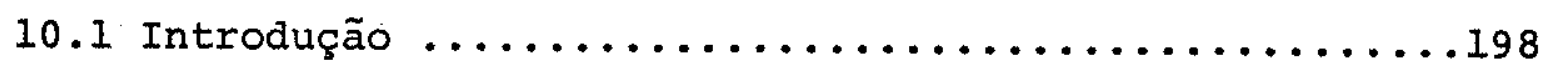

10.2 Metodologia dé avaliação .................... 198

10.3 Estimativas de custos ...........................

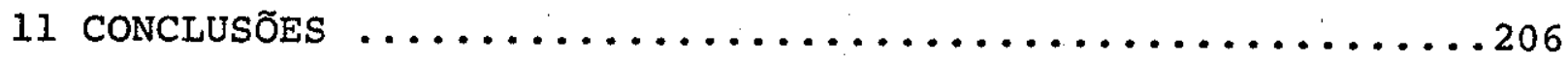

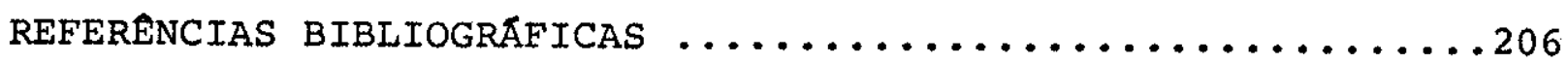

VOLUME 2

ANEXO A - Inventärio complementar de poços tubulares, cacim bas e fontes ........................ 1

ANEXO B - Tabelas ............................... 10

ANEXo C - Ensaios de bombeamento .................117

ANEXO D - Mapas e seções hidrogeológicas ...............142 


\section{ILUSTRAÇÕES}

TABELAS

N8

Tĩtulo

P.

1 Dados de sondagens elétricas verticais na Bacia Poti guax

2 a Dados de isótopos ambientais de äguas pluviais do nor deste brasileiro ......................... I4*

2b Dados de isótopos ambientais de äguas fluviais do nordeste brasileiro ....................... 15*

3a Dados de isōtopos ambientais nas āguas subterrâneas do aquifero Barreiras ..................... 16*

3b Dados de isōtopos ambientais nas ãguas subterrâneas do aquifero Jandaira da Bacia Potiguar ...........

3c Dados de isōtopos ambientais nas águas subterrâneas do aquifero Açu da Bacia Potiguar.............. 18*

4 Frequências de probabilidade de vazões específicas.. 19*

5 Dados de vazão específica e de transmissividade ob tidos atravēs de ensaios de bombeamento ......... 20*

6 Volumes anuais de ägua escoada pelos exutórios natụ rais do aquifero Jandaira .................. 109

7 Volumes anuais de ägua drenada do aquífero Jandaira para o aquífero Açu ...................... 111

8 Volumes anuais de ägua drenada do aquífero Açu para o aquifero Jandaira ..................... 111

9 Volumes anuais de āgua drenada do sistema aquífero

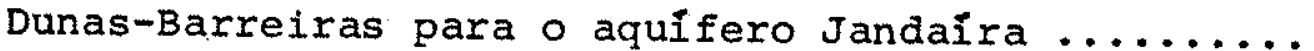

10 Listagem de dados gerais das amostras e parâmetros físico-quimicos das águas .................. 25*

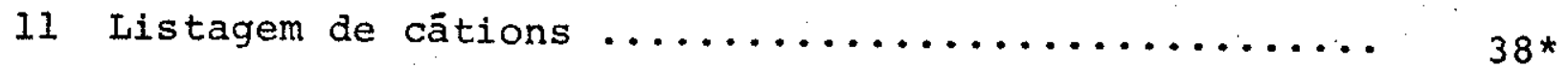

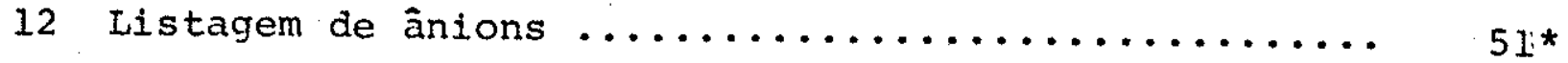

13 Listagem de relações iônicas ................. 64 *

* Tabela constante do ANEXO B, VOlume 2. 
14. Ltstagem de Indices hidrogeoquímicos ............ 77*

15 Iistagem das porcentagens de miliequivalentes ..... 90*

16 Listagem da dominância relativa dos ânions e dos cấ

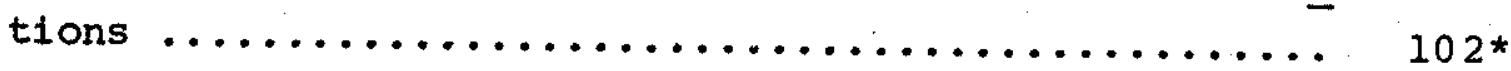

17 Correspondência dos números dos poços nos cadastra mentos das diferentes entidades ................ 114*

18 Composição química mëdia das āguas do aquífero Jan daíra, comparativamente às àguas de chuvas ........ 122

19 Poços anômalos em relação ao intervalo de confiança

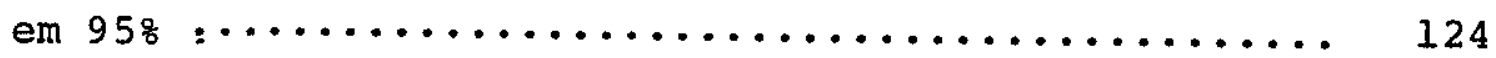

20 Dados de Resíduo seco de ãguas de poços e cacimbas medidos em diferentes datas ................. 115* $\Varangle$

21 Asșociação de amostras de ãgua obtida por anālise de

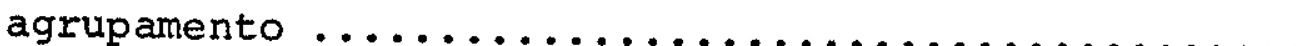

22 Classificação das āguas pelos ions dominantes ..... 151

23 Parâmetros estatisticos dos constituintes quimicos, físico químicos e das relações iônicas para os dife rentes tipos de ăguas .................... 155

24 Padrões para água de uso industrial ............ 117

25 Custo de produção do $\mathrm{m}^{3}$ de ägua pelos poços-padrão . 205

* Tabela constante do ANEXO B, VOLUME 2. 


\section{QUADROS}

N8

Título

1 Pluviometria anual média na Bacia potiguar ......... 18

2 Temperaturas mensais médias na Bacia Potiguar ...... 20

3 Insolação mensal média na Bacia Potiguar .......... 21

4 Velocidade mëdia de ventos na Bacia Potiguar ...... 21

5 Valores mensais médios de umidade relativa do ar na Ba

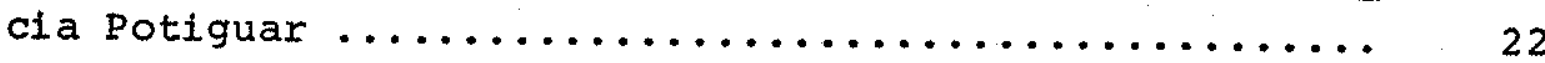

6 Evaporação Potencial mensal mëdia na Bacia Potiguar ..

7 Campanhas de medições geoelëtricas de longo alcance

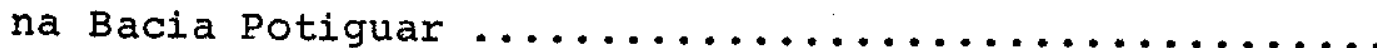

8 Caracteristicas geoelētricas das principais. formações

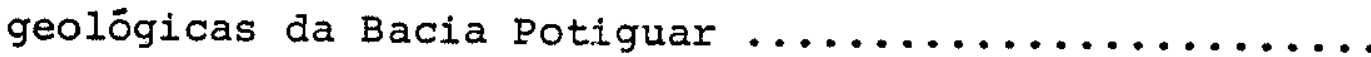

9 Caracteristicas geoelétricas da seqtuência estratigräfi cas do extremo oriente na Bacia Potiguar ...........

10 Parămetros estatísticos de vazão especifica, transmissi

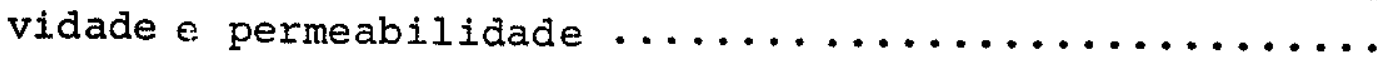

11 Pluviometria anual média na área de exposição dos ç̣

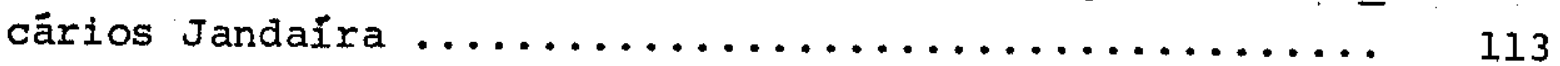

12 Origem das amostras de ägua $\ldots \ldots \ldots \ldots \ldots \ldots \ldots \ldots \ldots \ldots \ldots . \ldots \ldots$

13 Teores médios de constituintes químicos das äguas dos aquíferos Jandairra, Açu, Barreiras e Cristalino no Es

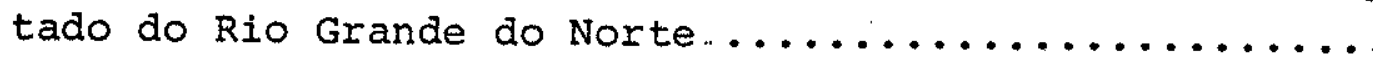

14 Frequência de anomalias dos parâmetros físicos e quí micos nas àguas dos poços.....................

15 Teores máximos dos constituintes químicos para $75 \%$ das

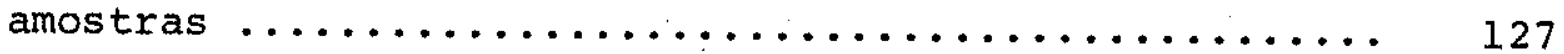

16 Classificação das äguas pelo Resíduo seco ......... 149

17 Classificação das águas pela Dureza Total . . . . . . . 149

18 Dados gerais dos Mapas hidroquímicos ............ 156

19 Frequência das amostras em relação aos padrões de pota bilidade 
20 Frequência das classes de ägua para fins de irrigação 180

21 Freqtência das amostras por categoria de salinidade e de RAS 181

22 Classificação das äguas para consumo animal ....... 183

23 Frequência do carāter das āguas em relação aos valores do Indice de estabilidade do carbonato de cálcio (IE). 185

24 Equipamentos de bombeamento utilizados nos poços do aquífero Jandaíra ........................ 193

25 Frequência dos poços e volumes explotados segundo os usos da ägua ............................ 197

26 Caracteristicas tëcnicas dos poços-padrão do aquífero Jandaira............................... 199 


\section{FIGURAS}

กัด

Titulo

P.

1 Localização da Bacia Potiguar ..................

2 Articulação das folhas topogräficas, escala 1:100 000

3 Mapa de isoietas do Estado do Rio Grande do Norte ...

4 Zoneamento climātico do Nordeste, segundo de Martonne.

5 Zoneamento climätico do nordeste (parcial) segundo koppen .............................. 26

6 Arcabouço estrutural da Bacia Potiguar ........... 28

7 Litoestratigrafia da Bacia Potiguar ............. 31

8 Mapa de dominância litológica aflorante em carbonatos

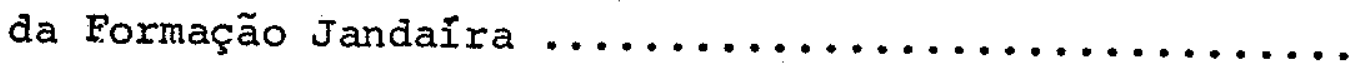

9 Distribuição de CaO-Mgo nas rochas carbonāticas do to po da Formação Açu e da Formação Jandaira............

10 Mapa com as äreas de dominância dos calcārios afloran

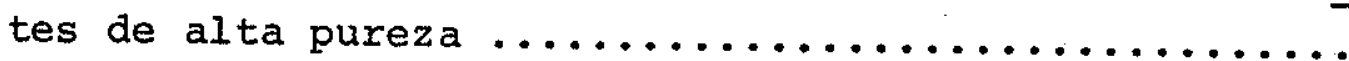

11. Mapa com as āreas de dominância das rochas dolomíti

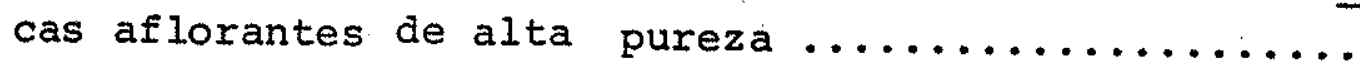

12 Exemplos de sondagens elétricas na porção ocidental

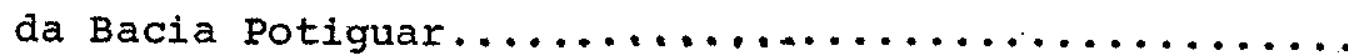

13 Exemplos de sondagens elétricas verticais na porção

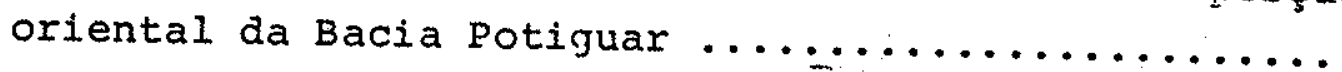

14 Exemplo de perfilagem tērmica em poços do aquífero Jandaira ............................

15 Relação entre $\delta D$ e $\delta 0^{18}$ em águas meteöricas do nordes

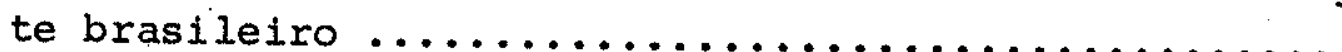

16 Relação entre $\delta D$ e $\delta 0^{18} \mathrm{em}$ ăguas fluviais do Nordeste

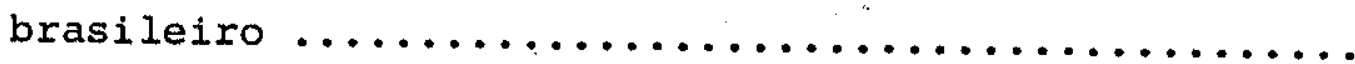

17 Relação entre $\delta D$ e $\delta 0^{18}$ em ãguas subterrâneas dos aquí

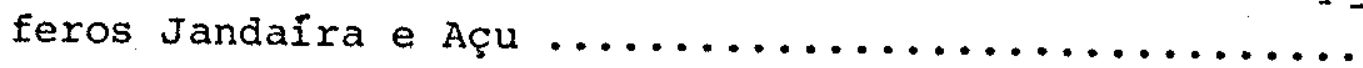

18 Representação da relação $\delta D$ e $\delta 0^{18}$ em āguas meteōricas, superficiais e subterrâneas do nordeste brasileiro e 
meteöricas segundo CRAIG ..................

19 Histograma de frequências dos valores de vazões espe cificas ............................

20 Diagrama de juntas ("boxplot") dos valores de vazão

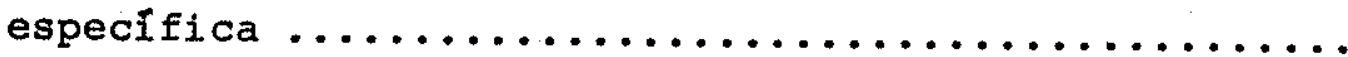

21 Distribuição de probabilidade lognormal dos valores de vazão especifica ........................

22 Distribuição de probabilidade lognormal para 9 classes de valores de vazão específica .............. 85

23 Relação entre vazão específica e profundidade dos poços 86

24 Curva acumulativa das médias das vazões específicas em intervalos de $10 \mathrm{~m}$ de profundidade ............

25. Relação entre vazão específica e profundidade dos ní

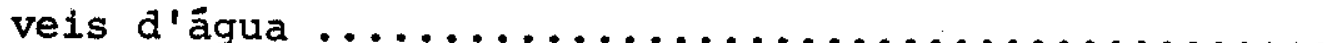

26 Histograma de freqtiencias de valores de transmissivî dade obtidos atravēs de ensaios de bombeamento ......

27 Histograma de frequências de valores de transmissividâ de obtidos através de ensaios e calculados atraves da

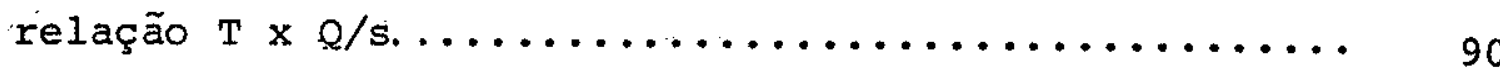

28 Relação entre : transmissividade e vazão especifica .

29 Histograma de frequências de profundidades de níveis d'ăgua estäticos nos poços ................... 98

30 Esquema do funcionamento hidräulico do aquífero Jan daíra

3la Frequência dos teores de Magnësio $\left(\mathrm{mg} / 1 \mathrm{Mg}^{+2}\right) \ldots \ldots$

31 brequẹncia dos teores de cálcio $\left(\mathrm{mg} / 1 \mathrm{Ca}^{+2}\right) \ldots \ldots . \ldots 128$

$31 \mathrm{c}$ Freqtência dos teores de södio (mg/l $\mathrm{Na}^{+1}$ ) .......

31 d Frequência dos teores de potăssio $\left(\mathrm{mg} / 1 \mathrm{k}^{+1}\right) \ldots \ldots$

31 e Frequência dos teores de Ferro (mg/l de $\mathrm{Fe}$ ) ......... 
$31 \mathrm{f}$ Freqtència dos teores de Fluoretos $\left(\mathrm{mg} / 1 \mathrm{~F}^{-1}\right) \ldots$

$3 \mathrm{lg}$ Frequência dos teores de cloretos $\left(\mathrm{mg} / 1 \mathrm{Cl}^{-1}\right) \ldots$

$3 \mathrm{lh}$ Freqtência dos teores de Bicarbonatos (mg/l $\mathrm{HCO}_{3}{ }^{-1}$ )

31 Frequência dos teores de carbonatos (mg/l $\left.\mathrm{CO}_{3}{ }^{-2}\right) \ldots$

$31 j$ Frequência dos teores de sulfatos $\left(\mathrm{mg} / 1 \mathrm{so}_{4}{ }^{-2}\right) \ldots$

$31 \mathrm{k}$ Frequência dos teores de Nitratos $\left(\mathrm{mg} / \mathrm{l} \mathrm{NO}_{3}{ }^{\prime} \mathrm{I}, \ldots .\right.$.

$31 \ell$ Frequência dos valores de $\mathrm{pH} \ldots \ldots \ldots \ldots \ldots \ldots \ldots \ldots$

$3 \mathrm{~lm}$ Frequência dos valores de Dureza total (mg/l $\mathrm{CaCO}_{3}$

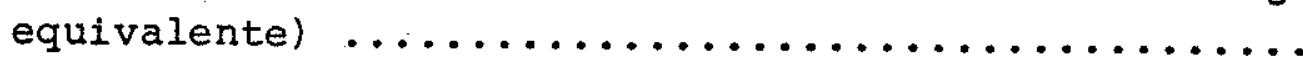

3ln: Frequềncia dos valores de conđutividade elētrica

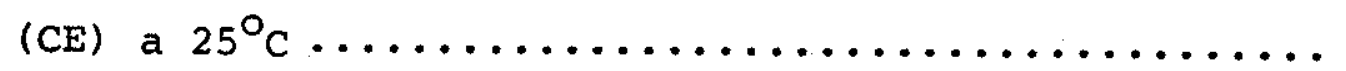

310 Freqtencia dos valores de TSD $(\mathrm{mg} / 1) \ldots \ldots \ldots \ldots$

31 prequência dos valores de Alcalinidade total (mg/1 $\mathrm{CaCO}_{3}$ equivalente) $\ldots \ldots \ldots \ldots \ldots \ldots \ldots \ldots \ldots \ldots \ldots \ldots \ldots \ldots \ldots$

31 Freqtência dos valores de Alcalinidade parcial (mg/l $\mathrm{CaCO}_{3}$ equivalente).

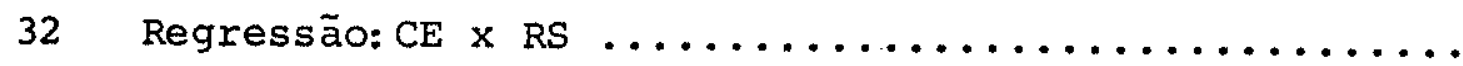

33 Regressão: CE x Soma de ions para o conjunto das 239 amostras

33b Regressão: CE x Soma de íons para āguas com dominān cia de cloretos .......................

$33 \mathrm{C}$ Regressão: $\mathrm{CE} \times$ Soma de íons para ăguas com dominân

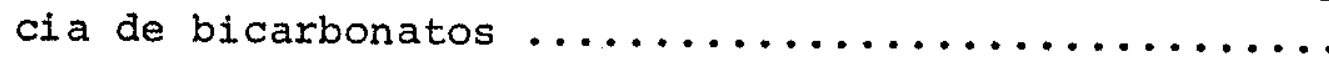

33d Regressão: CE $\times$ Soma de ions para ăguas com dominân cia de sulfatos ........................

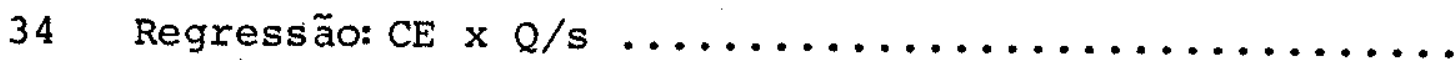

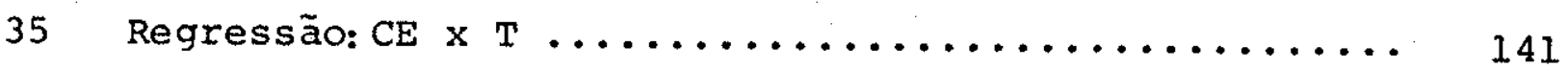

36 Regressão: CE x prof. NE ..................... 141

37 Regressão: $\mathrm{CE} \times$ espessura dos sedimentos de cobertura dos calcärios ......................... 142

38 Regressão: Soma de ions $x$ Cloretos.............. 143 
39 Regressão: soma de ions $x$ błcarbonatos ........... 143

40 Regressão: soma de ions $x$ sulfatos ................ 144

41 Regressão: soma de Ions $x$ sōdio ................ 144

42 Regressão: profundidade dos poços $x$ cloretos ........ 145

43 Correlação entre RS em ãguas de poços e cacimbas e a pluviometria ........................... 146

44 Classificação das äguas do Aquífero Jandairra segundo o

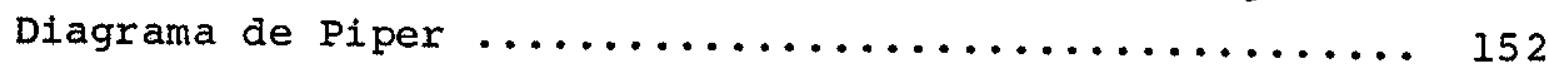

45 Poços construídos no Estado do Rio Grande do Norte no período $1918 / 79$ segundo os aquíferos ............. 188

46. Evolução da construção de poços tubulares no Estado do Rio Grande do Norte, no período $1918 / 79$, segundo os aquí

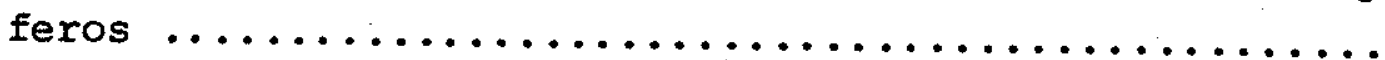

47 Evolução da construção de poços tubulares no Estado do Rio Grande do Norte, no periodo 1918/79, conforme ini ciativas particular ou püblica .................... 190

48 Poços construídos atē 1979 no Estado do Rio Grande do Norte, por aquifero, segundo iniciativas particular ou

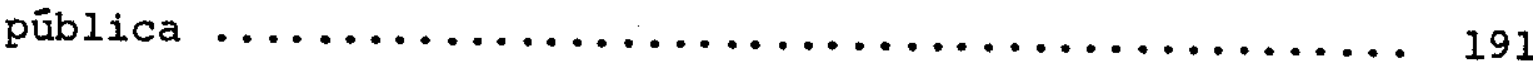

49 Histograma de frequências das profundidades dos poços 192

50 Estado atual dos poços do aquífero Jandaira (a) e mis tos (b) no Estado do Rio Grande do Norte ........... 194

51 Histograma de frequências dos valores de vazão ...... 195 


\section{MAPAS}

N8

Titulo

1 Mapa plani-altimētrico.

2 Mapa de drenagem superfictal.

3 Mapa geolögico.

4 Mapa de contorno estrutural da base da Formação JandaIra.

5 Mapa de isōpacas da Formação Janđaíra.

6 Mapa de freqliencia de direções das descontinuidades .

7 Mapa de direções mẻdias das descontinuidades.

8 Mapa de comprimento relativo das descontinuidades.

9 Mapa de frequência de descontinuidades.

10 Mapa de densidade de descontinuidades.

11 Mapa de contorno estrutural da base da cobertura da For mação Jandaíra.

12 Mapa de isōpacas da cobertura da Formação Jandaira .

13 Mapa de vazão específica.

14 Mapa piezométrico - janeiro 1980 .

15 Mapa de cotas dos níveis d'ägua no sistema Dunas-Barrei ras - março de $1979 / 80$.

16 Mapa de grupos de águas obtidos por anālise de agrupamento: .

17 Mapa de Total de Sólidos Dissolvidos (TSD) ...

18 Mapa de Dureza total.

19 Mapa de Cloretos.

20 Mapa de sulfatos.

21 Mapa de indices de troca de bases (ITB).

22 Mapa de Indice de estabilidade do carbonato de cälcio (IE) .

23 Mapa de diagramas de Stiff.

24 Mapa de classes de ãgua para irrigação. 


\section{ABSTRACT}

Data obtained from reports and publications on Geology, Hidrogeology, Hidrochemistry, Geophysics and Climatology of the Potiguar Basin complemented by new data from tube wells, dug wells and springs have been utilized in making a detailed study of the physical environment of the Jandaira aquifer.

On the basis of this study it has been possible to make an analysis and synthesis of lithological, dimensional and hydrody namical characteristics of the aquifer, its mechanisms of re charge and discharge, circulation pattern, reserves, hydroche mystry and quality of stored waters, water exploitation tech niques and different uses of waters.

The Jandaira aquifer is located in the upper portion of the Jandaira Formation, covers an area of $16278 \mathrm{~km}^{2}$, has mean saturated thickness of $150 \mathrm{~m}$ and is characteristically an uncon fined aquifer. It is hydraulically connected with the underlying Açu aquifer and along a narrow strip near the atlantic border with the overlying Dunas-Barreiras aquifer.

Considering the space variation of the litological com position, joints and faults, evidences of karstification and also the broad range of the transmissivity and specific capacity values, it is possible to say that the Jandaira is an heteroge nous and anisotropic aquifer, with characteristical karstic flow.

The most significant underground flow has its origin in the southern parts, near the contact of the Jandaira and Açu formations, with flow toward the ocean under a mean hydraulic gradient of $10^{-3}$. There are also secondary flows toward the Ja guaribe, Mossoró, Açu and Mulungu valleys, behaving drains like, conducting groundwater through their alluvial plains toward the ocean, with no manifestations of surface flow.

Rainfall is the main source of aquifer recharge and envi ronmental isotopes studies show that waters are subjected to intensive evaporation before reaching the aquifer. Stored waters can be divided in chloride (528), carbonate (218), sulfate (688) and a mixed one (218). 
Most of the aquifer is included in the Rio Grande do Nor te State where. 853 wells were inventoried in 1979, with an exploitation rate of $3,6 \times 10^{6} \mathrm{~m}^{3} /$ year. Waters were used for various purposes, being domestic and livestock the main uses.

Concentration of some water constituents, when compared with the requirements specified for human consumption, showed values higher than the maximun allowable limits: 698 of the samples had higher values of TDS (Total Dissolved Solids), 958 had higher hardness values, $77 \%$ showed higher $\mathrm{Mg}$, concen trations and $96 \%$ were outside the recommended fluoride concen tration interval.

Concerning agricultural uses these waters can be applied on crops with high tolerance for salt content and in soils with high permeability and good drainage. However some excess water must be used to induce salt lixiviation in soils.

In their natural state, waters of Jandaira aquifer are not suitable for industrial uses mainly due to their incrustation characteristics. 
RESUMO

Utilizando-se de dados levantados a partir de relatórios e publicações diversas sobre Climatologia, Geologia, Geofísica, Hidrogeologia e Hidrogeoquimica envolvendo a Bacia Potiguar e inventariação complementar de poços tubulares, cacimbas e fon tes, foram feitos estudos especificos que permitiram o conheci mento do meio físico, analisado como um sistema amplo no qual estä inserido o aquífero Jandaíra. Sobre essa base de conheci mentos foi possível então o aprofundamento, anālise e sintese dos conhecimentos sobre o aquifero no que concerne às suas ca racteristicas litolögicas, dimensionais ehidrođinâmicas, aos me canismos de recarga e circulação das ăguas, às suas reservas, à caracterização hidroquímica e qualidade das ãguas armazenadas, à engenharia de captação dos recursos e aos usos a que se desti nam as àguas explotadas.

- aquifero Janđaíra instala-se na porção superior da Forma ção Jandaira da Bacia Potiguar, com um dominio de $16278 \mathrm{~km}^{2}$ e uma espessura média saturada da ordem de $150 \mathrm{~m}$, apresentando-se caracteristicamente livre na maior parte do domínio. Conexões hidräulicas existem entre ele e a unidade sotoposta, o aquifero Açu, da mesma forma que numa estreita faixa junto à orla atlân tica ocorre conexão com o sistema aquifero Dunas-Barreiras, a ele sobreposto.

Consideradas a grande variação espacial da constituição li tolögica dos calcārios da Formação Jandaíra, as descontinuida des, as evidências de carstificação e ainda a amplitude dos vâ lores de vazão especifica e de transmissividade, o aquifero Jan daíra se apresenta heterogêneo e hidraulicamente anisotrópico, promovendo circulação tipicamente cárstica no seu interior.

o fluxo subterrâneo mais expressivo parte das äreas de re carga geralmente situadas a sul, nas proximidades do contacto entre as formações Jandairra e Açu, e interioriza as äguas no do minio do aquifero, levando-as com gradientes médios da ordem de $10^{-3}$, até os seus exutörios junto ao oceano. Secundariamente - fluxo se faz em direção aos vales dos rios Jaguaribe, Mossorō, Açu e Mulungu, que funcionam então como verdadeiros drenos, sem contudo constituir fluxo superficial, conduzindo-as ao oceano, provavelmente atravēs dos seus aluviöes. 
A recarga do aquifero se processa essencialmente por äguas pluviais e estudos de isótopos ambientais revelaram que essas ãguas são submetidas a Intenso processo de evaporação antes de participarem das reservas aquiferas. Das suas reservas partici pam $52 \%$ de águas cloretadas, $21 \%$ de ăguas bicarbonatadas, $6 \%$ de ăguas sulfatadas e $21 \%$ de águas mistas.

o acesso às reservas aquifferas é geralmente feito por cap tação através de poços tubulares que atingiram profundidade má xima de $300 \mathrm{~m}$. No Estado do Rio Grande do Norte, que cobre a maior parte da superficie de dominio do aquifero Jandaira, fo ram cadastrados 853 poços tubulares em 1979, que explotam cerca de $3,6 \times 10^{6} \mathrm{~m}^{3} /$ a de águas do aquifero, destinando-as aos mais diversos usos, sobressaindo-se no entanto o abastecimento domés tico e pecuărio.

Quando se comparam os teores de alguns dos constituintes das äguas do aquífero Jandaíra com padrões estabelectios em le gislação especifica, essas ãguas são insatisfatörias para consu mo humano. Dentre as amostras consideradas, grandes percentuais ultrapassam os valores ou intervalos recomendados tais como $69 \%$ para valores de TSD (Total de Sólidos Dissolvidos), 958 para Du reza total, $77 \%$ para teores de Magnésio e $96 \%$ para teores de Flúor.

No que concerne à adequação para usos na agricultura pôde- se constatar que devem ser somente aplicadas em culturas com alta tolerância a sais e em solos de alta permeabilidade e boa drenagem, devendo-se empregar água em excesso para promover a lixiviação de sais.

Em seu estado natural as ăguas do aquifero Jandaíra não são adequadas para consumo industrial devido principalmente ao seu carăter essencialmente incrustante. 
MONOGRAFIA DO AOQUIFERO JANDAIRA DA BACIA POTIGUAR

\section{INTRODUÇÃO}

A Bacia Potiguar, tambēm denominada Bacia do Apodi, estā situada no extremo nordeste do Brasil, entre os paralelos $4^{\circ} 10^{\prime}$ e $5^{\circ} 50^{\prime} \mathrm{s}$ e os meridianos $35^{\circ} 00^{\prime}$ e $38^{\circ} 20^{\prime} \mathrm{W}$. Ocupa uma superficie emersa de aproximadamente $25000 \mathrm{~km}^{2}$, dominando a metade se tentrional do Estado do Rio Grande do Norte e uma estreita fai xa no extremo nordeste do Estado do Cearä. Estende-se na dire Ção E-W por aproximadamente $300 \mathrm{~km}$, com a maior largura na por ção ocidental, atingindo cerca de $120 \mathrm{~km}$, estreitando-se para leste onde se reduz a apenas $40 \mathrm{~km}$, dando lugar à denominada Bacia Pernambuco-Paraíba (FIGURA I).
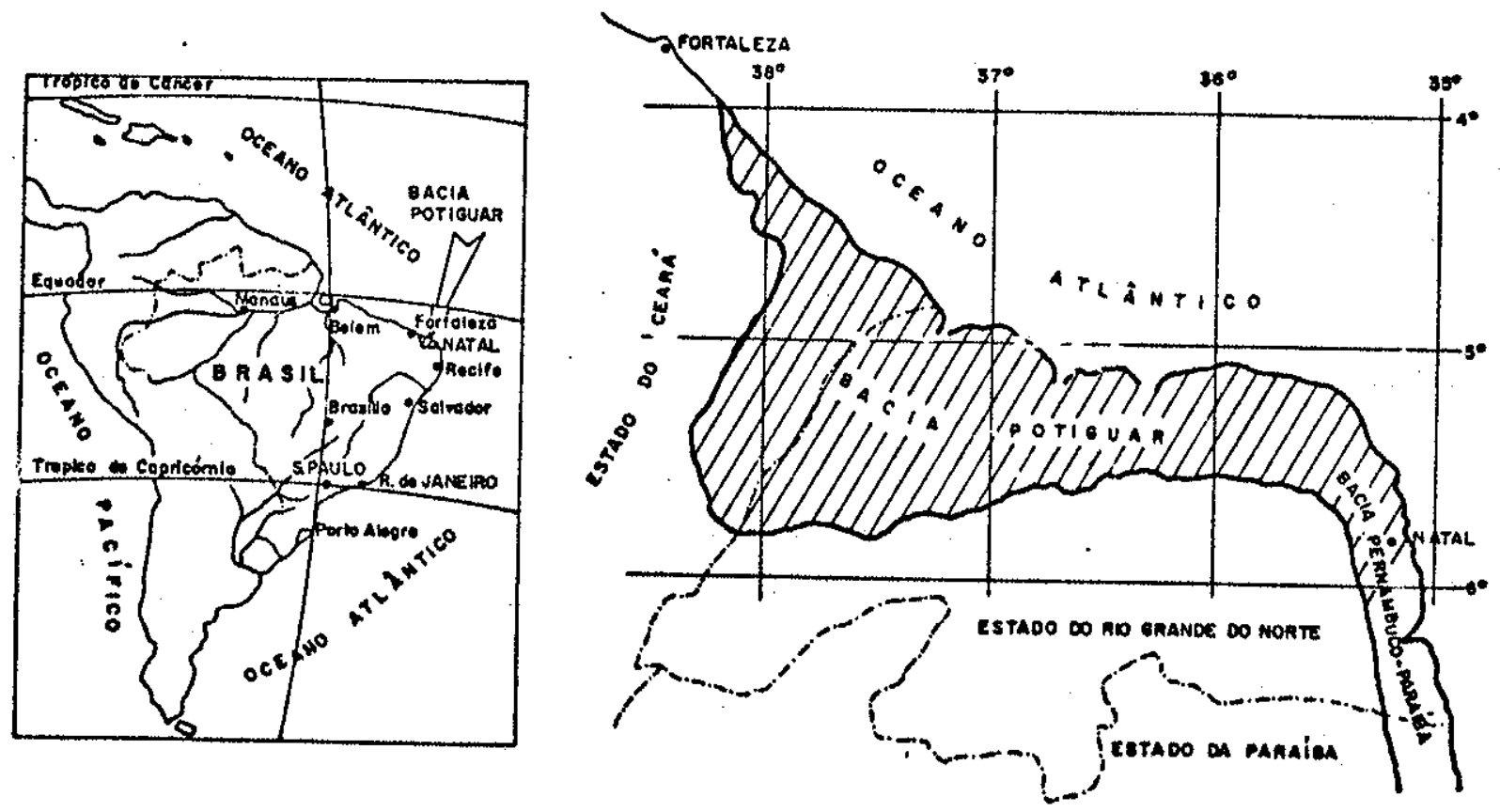

FIGURA 1 - Localização da Bacia Potiguar

No continente os limites da Bacia Potiguar ocorrem apro ximadamente ao longo de uma linha que, de oeste para leste, une as cidades de Aracati (CE), Jaguaruana (CE), Russas (CE), Limoei ro do Norte (CE), Potiretama (CE), Apodi (RN), Caraúbas (RN) Upanema (RN), Açu (RN), Afonso Bezerra (RN), Pedro Avelino (RN), 
João Câmara (RN), Cearämirim (RN) e Natal (RN). Na parte subma rina os seus limites são ainda desconhecidos.

Resultante de um tectonismo relativamente brando de disten são crustal que gerou uma calha periclinal com mergulho para nordeste - para o oceano, a Bacia Potiguar, em sua porção emer sa, contēm sedimentos paleozöicos, representados pelas forma çōes Pendência (folhelhos, siltitos e arenitos), Açu (arenitos finos a grosseiros e siltitos argilosos) e Jandaíra (calcários, margas, siltitos, dolomitos e folhelhos) e sedimentos cenozói cos representados pelo Grupo Barreiras (areias finas a mēaias com intercalações argilosas), aluviōes e dunas.

\section{1 o contexto hidrogeológico da Bacia Potiguar}

Na Bacia Potiguar destacam-se duas unidades aquiferas de ocorrência regional, reconhecidas desde os primeiros estudos hi drogeológicos realizađos na ärea, a saber:

- aquifero Açu - representado, via de regra, pela porção basal da Formação Açu; unidade aquífera constituida por uma camada com porosidade primária intersticial na qual predominam condi ções de semiconfinamento;

- Aquífero Jandarra - sobreposto ao anterior, representado pela porção superior de sequência carbonātica da Formação Jandaîra; unidade aquifera constituída por uma camada com porosidade predominantemente secundäria (por fraturamento e carstifica çãol, apresentando-se localmente litologicamente heterogê nea e hidraulicamente anisotrōpica, com circulação cārstica; porém regionalmente considerada homogênea, e isotröpica, com predomínio de condições livres na maior parte de seu dominio.

As duas unidades aquiferas apresentam-se superpostas e em conexão hidráulica através de uma camada pouco permeãvel, cor respondente à porção inferior da Formação Jandaira e superior da Formação Açu.

Sobrepondo-se ao aquifero Jandaira, em uma estreita faixa em sua porção norte, estão presentes os sedimentos do grupo Bar reiras e as dunas que, em algumas äreas, podem se constituir em um sistema aquifero livre Dunas-Barreiras, onde exerce influên 
cia hidrăulica e hidroquimica sobre o aquifero Jandaíra.

Devido à extensa ārea de domínio do aquífero Jandaỉra (16 $278 \mathrm{~km}^{2}$ ) e devido tambēm à facilidade de acesso ao recurso hïdrico, por ser a Formação Jandaira aflorante na maior parte do seu dominio $\left(10298 \mathrm{~km}^{2}\right)$, esse aquifero se reveste de extrema importância no suprimento de água para consumo humano e animal dessa região semi-ārida. Assim é que dos 1300 poços cadastra dos pelo Instituto de Pesquisas Tecnológicas do Estado de são Paulo-IPT na área da Bacia Potiguar, 760 deles captam āguas do Aquifero Jandaira (IPT, 1982).

\subsection{Objetivos da Monografia do Aquifero Jandaira}

Os estudos hidrogeológicos até agora realizados na Bacia Potiguar tornaram evidente a necessidade de um estudo especifi co do Aquifero Jandaira. Esta monografia tem como objetivos ana lisar, aprofundar e sintetizar os conhecimentos hidrogeológicos atë agora ađquiridos atravēs dos diferentes estudos realizados na área da Bacia Potiguar e que envolveram o Aquifero Jandaira. Tal investigação e sintese têm suas bases no que concerne à quan tificação dos recursos hidricos do Aquifero Jandaira, à caracte rização hidroquimica, aos mecanismos de recarga e circulação das āguas, à engenharia de captação desses recursos e aos usos a que se destinam as ăguas explotadas.

\subsection{Metodologia Geral}

Para a consecução dos objetivos propostos para esta Mono grafia, considerou-se a necessidade, por um lado, do conhecimen to do meio fisico a ser analisado como um sistema amplo que abriga o Aquifero Jandaira e, por outro, da avaliação da inte ração do Homem com esse sistema, que se processa atravēs do aces so e uso dos recursos hidricos desse aquifero. Esses conhecimeñ tos para a anālise e avaliação, julgou-se possível serem obtí dos através das atividades a seguir expostas.

\section{a) Levantamentos bibliogräficos}

Levantamento de literatura que incluisse a Bacia Potiguar e que contivesse dados de interesse nas seguintes äreas: Geolo gia, Geomorfologia, Geofisica, Pedologia, Hidrogeologia, 
Hidrologia de Superficie (Pluviometria e Fluviometria) e clima tologia. A análise da literatura selecionada permitiu a compila ção dos dados de interesse para os estudos realizados nos dife rentes campos das investigações, com os quais foi possível a ela boração de mapas, relações, tabelas, grăficos, etc.

Considerando-se o ponto d'ägua como a principal fonte de informações para os estudos hidrogeológicos, procurou-se, nesta fase, correlacionar os pontos inventariados pelas diferentes en tidades que desenvolveram os estudos. Dificuldades de correla ção, impediram porém, a utilização de grande parte de dados con tidos nos documentos.

\section{b) Complementaça de dados e informações}

Novos dados de interesse foram levantados junto à Compa nhia de Desenvolvimento de Recursos Minerais do Rio Grande do Norte - CDM/RN, entidade estatal construtora de poços tubulares e que atua na área de estudos. Assim foram obtidos novos dados de construção de poços, de ensaios de bombeamento e de análises físico-quimicas de āgua. Para o cadastramento de poços, comple mentar ao efetuado pelo IPT, foram utilizadas as folhas topogrä ficas em escala 1:100 000, da SUDENE, cuja articulação e codifi cação são apresentadas na FIGURA 2. Cada ponto cadastrado rece beu o nümero da folha topográfica seguido do nümero de ordem de cadastramento. A inventariação complementar è apresentada no ANEXO A.

\section{c) Tratamento de dados obtidos}

Os dados obtidos foram então sistematizados de acordo com os objetivos de cada ärea de investigação hidrogeolögica para possibilitar o tratamento dos mesmos, de acordo com as técnicas inerentes a cada uma dessas āreas e que serão explanadas na apre sentação dos temas desenvolvidos. 


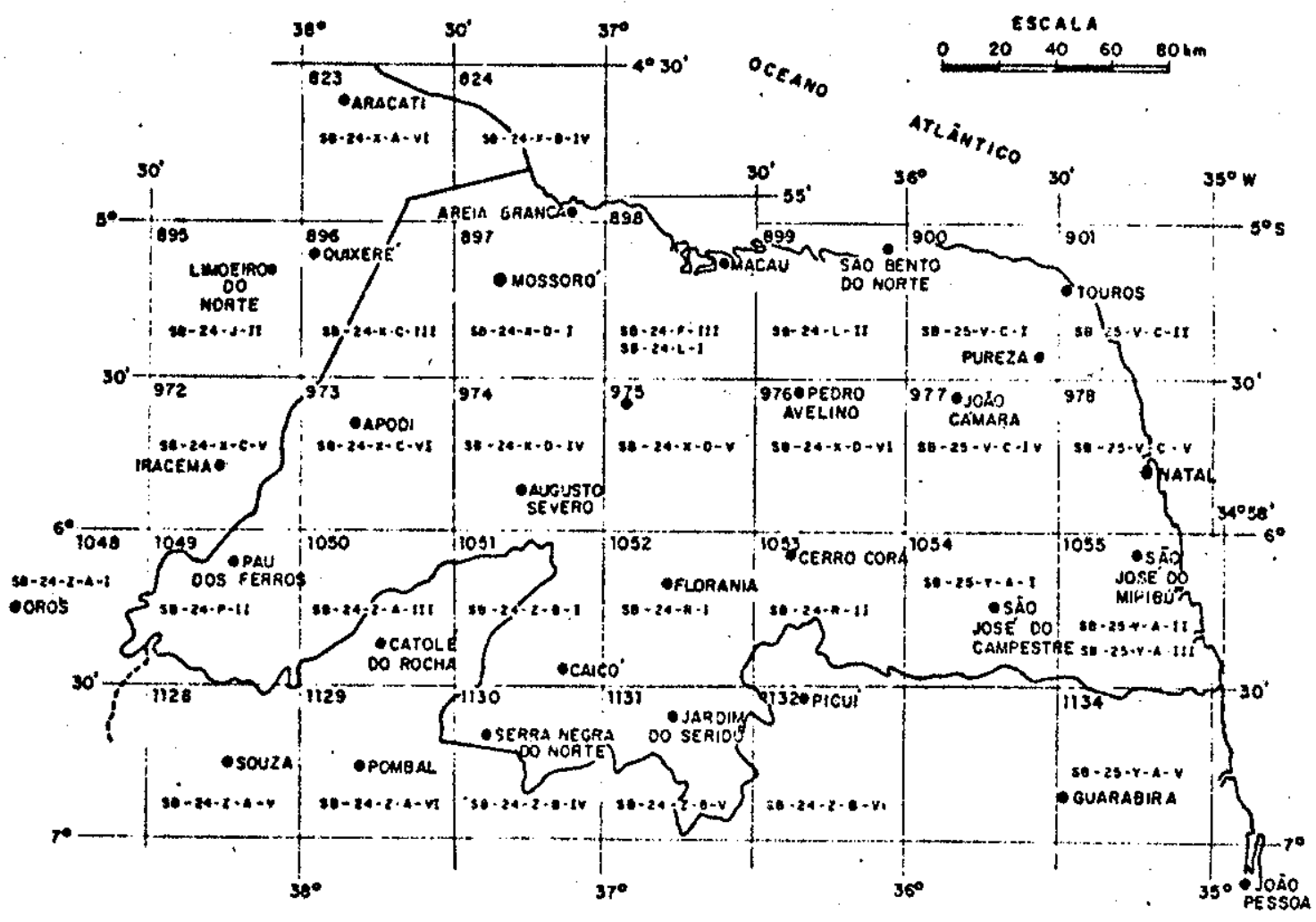

FIGURA 2 - Articulação đas folhas topogräficas, escala 1:100 000. 
2 BREVE HISTORICO DOS ESTUDOS HIDROGEOLOGGICOS NA BACIA

POTI

GUAR

A bibliografia referente a recursos hỉdricos subterrâneos na área da Bacia potiguar inclui estudos realizados no início deste século. A partir de 1967, porém, a Superintendência do De senvolvimento do Nordeste - SUDENE, (criada pela Lei 3692 de 15 de dezembro de 1959) começa a publicar os resultados dos primei ros estudos hidrogeológicos sistemáticos realizados na área.

Atualmente se dispõe de um bom nümero de publicações abor dando aspectos hidrogeológicos da Bacia Potiguar. Citaremos a seguir os trabalhos já realizados, em sequência cronolōgica de sua publicação e as principais fontes de veiculação desses co nhecimentos.

1910

- O Ministērio da Viação e Obras públicas, através da Inspetô ria Federal de Obras Contra as Secas - IFOCS, publica: "Geo graphia, Geologia, suprimento d'água, transporte e açudagem nos estados orientais do Norte do Brasil: Ceará, Rio Grande do Norte, Parahyba". (CRANDALL, 1910).

\section{$\underline{1912}$}

- A IFOCS publica: "Suprimento d'água no nordeste do Brasil. (WARING, 1912).

1913

- A IFOCS publica o primeiro trabalho sobre suprimento de água subterrânea na região: "Geologia e suprimento de água subter rânea no Rio Grande do Norte e Parahyba". (SOPPER, 1913).

1937

- O Departamento Nacional da Produção Mineral - DNPM, publica: "Água subterrânea - Estado do Rio Grande do Norte". (PAIVA, 1937).

$\underline{1954}$

- O Governo do Estado do Rio Grande do Norte publica trabalhos 
sobre āguas subterrâneas, realizados no bojo de estudos agro geolögicos: "As águas subterrâneas no Estado do Rio Grande do Norte". (VAGESACK, 1954), em levantamento agrogeológico do es tado, elaborado por VAGELER e outros.

\section{2}

- A PETROBRÁs elabora o primeiro estudo sobre água subterrânea a nỉvel regional do Estado do Rio Grande do Norte, em documen to intitulado: "Geological Summary and Ground Water Potential of the Potiguar Basin in Rio Grande do Norte". (BLANKENNAGEL, 1962, inēdito).

\section{5}

- A SUDENE, contando com a cooperação tēcnica francesa (Associa tion pour L'Organisation des Missions de Cooperation TechniqueASMIC) iniciou um programa de formação de técnicos especializâ dos no campo da Hidrogeologia, Geofísica e Perfuração de Pô ços na Bacia Potiguar, selecionada como "Bacia Escola de $\mathrm{H} \underline{\text { i }}$ drologia".

- O DNPM publica dois trabalhos enfocando as águas subterrâneas na Bacia Potiguar: "Reconhecimento hidrogeológico no Vale Açu do rio Piranhas". (ARAUUO \& RODIS, 1965), iniciando-se assim os estudos de semi-detalhe dentro do dominio da Bacia poti guar, com sistematização metodológica específica para estudos hidrogeológicos.

\section{6}

- A Sociedade Brasileira de Geologia publica nos anais do Sim pósio de Geologia do Nordeste: "Faixa sedimentar costeira(Per nambuco, Paraíba e Rio Grande do Norte) - aspectos hidrogeoló gicos (REBOUÇAS, 1966).

\section{7}

- A Superintendência de Desenvolvimento do Nordeste - SUDENE pü blica estudos hidrogeológicos realizados no domínio da Bacia Potiguar:

"Bacia Potiguar: estudo hidrogeológico" (REBOUÇAs e outros, 1967) e "Estudo geral de base do vale do Jaguaribe (SUDENE/ ASMIC, 1967). 
1969

- A SUDENE publica ainda novos estudos hidrogeológicos no âmbi to da Bacia Potiguar: "Ground Water in northeastern Brazil". (SOUTO MAIOR, 1969) e "Bacia Potiguar - estudos por analogia elētrica das condições de exploração das águas subterrâneas do arenito Açu na região de Mossoró, RN". (MANOEL FILHO e ou tros, 1969). Este foi o primeiro estudo tentativo que se fez para a utilização de modelos de simulação de aquífero da Bâ cia Potiguar.

$\underline{1970}$

- E a partir de 1970 que a SUDENE, atravês da "Série Hidrogeolo gia" começa a apresentar os trabalhos de maior importância e repercussão no campo da Hidrogeologia Regional, com a publi cação dos Inventārios hidrogeológicos básicos no nordeste en volvendo a Bacia Potiguar. Assim temos:

"Inventário hidrogeológico básico do nordeste. Folha no 10.Ja guaribe-NE". (MANOEL FILHO, 1970).

"Inventário hidrogeológico básico do nordeste. Folha no 14.Ja guaribe-SO". (CRUZ \& FRANÇA, 1970).

"Inventārio hidrogeológico básico do nordeste. Folha no 15.Ja guaribe-SE". (ALBUQUERQUE, 1970).

$\underline{1971}$

- A SUDENE publica novo estudo hidrogeológico envolvendo a Ba cia Potiguar: "As āguas subterrâneas do nordeste: estimativas preliminares". (REBOUCAS \& GASPARY, 1971).

$\underline{1972}$

- A SUDENE publica "Hidrologia das secas: nordeste do Brasil" (REBOUÇAS, 1972).

1973

- A SUDENE publica o "Reconhecimento hidrogeológico da planície aluvial do Apodi; RN: definição preliminar de viabilidade pa ra irrigação" (MANOEL FILHO, 1971).

1974

- A SUDENE publica os resultados de novos estudos hidrogeológi cos envolvendo o dominio da Bacia potiguar, a saber: 
"Estudo geoquỉmico preliminar das āguas subterrâneas do nor deste do Brasil". (CRUZ \& MELLO, 1974).

"Caracterização de āguas do nordeste brasileiro com isótopos ambientais". (LEAL et alii, 1974).

A partir de 1957, a Universidade Federal de Pernambuco-UFPecom trabalhos independentes e também em convênio com diferen tes entidades federais (SUDENE e MEC) e estaduais (CDM/RN, etc) tem contribuỉdo com estudos geológicos e hidrogeológicos em diferentes áreas dos estados nordestinos, publicados através de relatōriospara graduação em Geologia. Assim, em 1974 foram publicados vários trabalhos executados no domínio dos calcá rios da Formação Jandaỉra, tais como:

"Aspectos geológicos e hidrogeológicos em áreas dos municípios de Touros, Pedra Grande e Parazinho, RN". (AGUIAR, 1974).

"Geologia e aspectos hidrogeológicos dos municípios de pedra Grande, Parazinho e João Câmara, RN". (ARRUDA PINTO, 1974). "Geologia e aspectos hidrogeológicos em āreas de municípios de Touros, Pedra Grande e Parazinho, RN". (OLIVEIRA, 1974). "Geologia e aspectos hidrogeológicos em áreas do município de são Bento do Norte, Parazinho e Pedra Grande, RN". (TEIXEI RA, 1974).

- O DNOCS, em convênio com a SERETE S.A. - Engenharia, executa estudo hidrogeológico de detalhe e publica o "Estudo hidrogeo lógico do Baixo Açu".

- A SUDENE, em convênio com o DRN/CONESP/OESA, efetua o "Estudo de reconhecimento e Estudos hidrogeológicos para aproveita mento integrado; região centro-oeste da Bacia Potiguar e Bâ cias Costeiras da Paraỉba e Pernambuco - Årea A".

$\underline{1977}$

- A SUDENE, atravēs do convênio MINTER-SUDENE-DRN/MEC-UFPE-CT e xecuta trabalhos de detalhe também no vale do rio Apodi, den tro do denominado "Estudo hidrogeológico da planície aluvial do Apodi, RN - Economicidade de poços para irrigação". (SAN TOS, 1977). 
1978

- O Departamento Nacional de Obras Contra as Secas - DNOCS, em convênio com a HIDROSERVICE, elabora o "Plano Diretor para o aproveitamento dos recursos de solo e água no Vale do Apodi, Rio Grande do Norte".

$\underline{1980}$

- A SUDENE publica o "Plano de aproveitamento integrado dos re cursos hidricos do nordeste do Brasil - Fase I" onde aborda genérica e resumidamente os recursos hỉdricos subterrâneos da Bacia Potiguar.

1982

- A Secretaria de Indûstria e Comércio do Estado do Rio Grande do Norte - SIC/RN em convênio com o Instituto de Pesquisas Tec nológicas do Estado de são Paulo - IPT, elabora o relatório fınal do "Estudo hidrogeológico regional detalhado do Estado do Rio Grande do Norte". 


\section{FISIOGRAFIA DA BACIA POTIGUAR}

\subsection{Geomorfologia}

A morfologia da Bacia Potiguar è caracterizada por uma cha pada relativamente plana, constituída pela sequência sedimentar trabalhada ainda no Plioceno, que mergulha suavemente em direção ao oceano. Essa feição na porção oeste da Bacia é conhecida gene ricamente pelo nome de Chapada do Apodi, representada pela super fície aflorante dos calcários da Formação Jandaíra (MAPAS 1 e 3). Ai se encaixam os vales de dois dos principais rios da Bacia: rio Apodi-Mossoró e rio Upanema-do Carmo. (MAPA 2).

Nos limites sul e oeste da Bacia Potiguar essa monotonia é abruptamente interrompida por escarpas onde se apresenta uma frente de "cuesta" instalada no contato entre os calcärios da Formação Jandaíra e os arenitos e siltitos da Formação Açu a ela

sotoposta. Esse relevo de "cuestas" é encontrado desde o extre mo noroeste da Bacia, a partir da Serra Dantas e Serrote dos Porcos, ambas correspondentes a afloramentos de rochas cristali nas no interior da Bacia, seguindo ao longo da planicie aluvial do rio Jaguaribe até a cidade de Tabuleiro do Norte (CE). Diri ge-se depois para sul atë Apodi (RN), desviando-se depois para leste, passando por Upanema (RN), tornando-se gradativamente atípica e completamente obliterada a leste do vale do rio Açu. A partir daí então aparece de maneira reticente e com pequenos desniveis topogräficos.

A topografia da Bacia potiguar é pouco acentuada e caracte rizada por um relevo muito pouco movimentado, apresentando co tas de 10 a $20 \mathrm{~m}$ junto à costa, ascendendo gradualmente para o interior, com a maior parte da ärea da Bacia porém compreendida entre 0-150 m (MAPA 1). Esse relevo monótono ē às vezes inter rompido por vales abertos, de direção geral NNE-SSW, correspon dentes aos lineamentos estruturais dominantes do embasamento cristalino, tais como os vales dos rios Apodi-Mossoró, Piranhas -Açu e vales de menor expressão, com orientação aproximada N-S, por vezes transversais às estruturas regionais como 0 vale do rio do Carmo e do rio Cabugi-Mulungu-nmargoso.

Algumas áreas com altitudes mais pronunciadas e com dire ఢão grosseiramente estabelecida $S W-N E$, se destacam nessa paisa gem de platô (MAPA 1): 
a) no extremo noroeste da ārea, a sudeste de Jaguaruana (CE), servindo como referencial de limite entre os Estados do Ceară e Rio Grande do Norte, surgem a Serra Dantas, com altitude mâ xima de $232 \mathrm{~m}$ e o Serrote dos Porcos, com $186 \mathrm{~m}$, ambas sus tentadas por rochas pré-cambrianas quartzíticas;

b) a noroeste de Mossoró se destaca uma elevação isolada encí mada por sedimentos do Grupo Barreiras (item 5.3.8) denomina da Serra de Mossoró, que atinge $265 \mathrm{~m}$ de altitude;

c) no extremo sudoeste da Bacia, a oeste da cidade de Apodi e sustentada por sedimentos da Formação Açu (item 5.3.5) apre senta-se uma extensa ārea, topograficamente a mais elevada da porção oeste da bacia, também servindo de referencial para a divisa dos estados do Rio Grande do Norte e Ceará, ramifica da em dois corpos:' o primeiro, com direção N-S e altitude mạ xima de $257 \mathrm{~m}$; o segundo com direção $\mathrm{E}-\mathrm{W}$ e altitude máxima de $285 \mathrm{~m}$, separados por uma região baixa onde se instala o Riacho da Barra, com direção $S W-N E$, encaixado em zona de a Iha (MAPAs 1, 2 e 3). Ainda nessa ārea elevada, a noroeste de Potiretama ( $\mathrm{CE}$ ) jā fora do dominio da Bacia porém próxí mo à sua borda, chama a atenção uma área de forma circular apresentando altitude mäxima de $200 \mathrm{~m}$, recoberta por sedimen tos da Formação Açu, esculpida pelo riacho seco que a circun da ao norte e pelo riacho do Logradouro, ao sul.

d) a nordeste de Caraúbas, na localidade denominada Retiro, e sustentada tambëm por sedimentos da Formação Açu, ocorre uma elevação de pequena expressão em ārea que atinge porēm $205 \mathrm{~m}$ de altitude;

e) entre Mossorö e Carnaubais, encontramos talvez a mais forte expressão do relevo na Bacia Potiguar, constituida pelo con junto denominado: Serra do Carmo, serra do Mel e serra do Cajueiro, instaladas, graças à cobertura dos calcários Jan daira pelos sedimentos do Grupo Barreiras. As altitudes aí atingem $271 \mathrm{~m}$, na Serra do Carmo;

f) entre João Câmara e Janđaira se situam as maiores elevações da porção oriental da Bacia potiguar. As elevações rochosas que aqui se instalam, ainda com direção geral SW-NE, podem 
ser apresentadas em três sẹtores (MAPA 1):

- orimeiro setor, situado mais ao sul, com as cristas orion tadas na direção $\mathrm{SW}-\mathrm{NE}$, se constitui essencialmente nas elevações das rochas cristalinas mais pröximas da margem da Bacia. A altitude mäxima è de $261 \mathrm{~m}$, na serra do Lombo, a noroeste da cidade de Pedra Preta, já na ārea de cobertú ra daquelas pela Formação Açu;

- o segundo setor, mais amplo, de direção E-W, corresponde à continuação do corpo anteriormente descrito, porém jā to talmente dentro do dominio da Bacia Potiguar, instalando- se ao longo do contacto dos sedimentos da Formação Açu com os calcārios da Formação Jandaíra. A sua porção oeste recebe a denominação de Serra Verde e apresenta altitude mäxima de $295 \mathrm{~m}$ a sudoeste da cidade de Jandaíra; a porção leste recebe a denominação de Serra da Macambira, apresen tando altitude máxima de $268 \mathrm{~m}$, na localidade denominada Serrinha, a oeste da cidade de João Câmara;

- O terceiro setor, a Serra dos Macacos, também de direção SiV-NE, a norte de João Câmara, atinge a altitude mäxima de $310 \mathrm{~m}$ na localidade denominada Baixa dos Macacos. Este se consti tui no ponto de maior altitude no interior da Bacia Poti guar. o conjunto do segundo e terceiros setores são porēm conhecidos regionalmente com a denominação genérica de ser ra Verde.

Correlacionando-se a topografia (MAPA l) com a geologia da ārea (MAPA 3), pode-se notar que algumas das elevações māxi mas desse maciço se instalam sobre afloramentos de rochas ultra básicas - derrames basálticos do Terciärio - como é o caso, por exemplo, da Serra Preta, a nordeste de Pedro Avelino, com $228 \mathrm{~m}$, e a Serra Aguda, prōximo à anterior, com $267 \mathrm{~m}$. Fora do domínio da Bacia Potiguar, em ārea de rochas cristalinas, porém originā ria das meṣmas manifestações basälticas deve ser citada a serra do Cabugi, a oeste de Lages, onde se ergue o Pico do Cabugi com $590 \mathrm{~m}$, com feição conspicua de chaminé vulcânica (item 5.3.7.). Observando-se ainda a drenagem. (MAPA 2) e o relevo (MAPA 
1). nota-se que esse conjunto rochoso se constitui em um impor tante divisor das äguas superficiais.

De menor expressão topogräfica, porëm com forma tipicamente dômica, apresenta-se nitida a Serra do Mangue seco, situada junto à costa norte, a sudoeste de Guamarē e que atinge apenas $104 \mathrm{~m}$.

Na região costeira encontramos os cordões de dumas que no litoral norte são menos expressivos do que no litoral leste. Os cordões de dunas möveis ora se sobrepõem aos sedimentos do Gru po Barreiras, ora às dunas fixas prë-existentes.

os sedimentos dunares quando são interrompidos pela desem bocadura dos maiores rios, œdem lugar aos aluviões. Tal feição pode ser encontrada na foz do rio Apodi-Mossoró (em Grossos) rio Piranhas-Açu (em Pendências), rio Mulungu - Amargoso (em Macau) e rio Camurupim (em Guamaré).

As planicies fluviais dilatam-se nas vizinhanças da foz on de se elevam muito pouco acima das marés altas, constituindo planícies quase horizontais, propiciando a formação de extensos alagamares. Nessas āreas se acham localizadas as grandes sali nas que alimentam uma das mais importantes atividades econômi cas da região.

As praias geralmente se desenvolvem em continuidade aos se dimentos dunares porēm às vezes podem se instalar no sopé de fá lésias esculpidas nos sedimentos do Grupo Barreiras, como ocor re, por exemplo, a nordeste da serra do Mel (Ponta da Pedra Grande) e Tibau.

\subsection{Drenagem}

Excetuando-se as grandes linhas que, vindo das äreas PrëCambrianas atravessam a bacia sedimentar, a drenagem no domí nio da Bacia potiguar é em geral pouco densa e caracterizada por uma rede preferencialmente difusa de riachos intermitentes com pequena expressão em ärea (MAPA 2). Hä ainda a presença, em äreas restritas, de arenagem endorrêica, convergindo para fun dos de dolinas esculpidas em āreas de afloramentos dos calcă rios da Formação Jandaíra, ou mesmo onde estes estão recobertos pelos sedimentos do Grupo Barreiras.

Quanto à drenagem principal, observando-se o mapa de estru 
turas geolögicas da Bacia Potiguar (FIGURA 6 item 5.2) e 0 de drenagem (MAPA 2) pode-se notar que os rios de maior porte, de uma maneira geral têm o traçado dos seus vales condicionado às principais Iinhas estruturais.

Esses rios, quase todos intermitentes, cortam transversal mente a seqtiencia sedimentar, vindos das äreas cristalinas ao sul.

Entre os rios mais importantes temos, de oeste para leste: rio Jaguaribe (CE), rio Apodi-Mossoró (RN), rio Upanema-do Car mo, rio Piranhas - Açu (RN), rio Cabugi-Mulungu-Amargoso (RN).

o rio Açu, desde 1961 tem tido em seu médio e baixo cursos um fluxo de āgua contínuo, embora bastante reduzido, devido à soltura periódica de águas armazenadas no açude Itãns, em caicó. Durante as enchentes transborda em suas margens chegando a in verter o curso de alguns de seus afluentes, como ocorre com o rio Pataxós que tem seu curso invertido por três a cinco sema nas, enchendo dois lagos situados a leste da cidade de Ipangua çu (ARAOJO \& RODIS, 1967).

A maioria dos rios acima mencionados corta o relevo de cha pada, e em alguns trechos como os correspondentes às entradas do rio Apodi e do rio Açu na bacia sedimentar, existem profun dos "canyons" nas āreas de contato dos sedimentos da Formação Açu com os calcārios da Formação Jandaíra.

Como visto no item anterior, a região da Serra Verde, ou seja, as elevaçöes de relevo entre João Câmara e Jandaíra (Ser ra Verde propriamente dita, Serra da Macambira e região da Baixa dos Macacos) se instala como divisor de águas superficiais, impondo à drenagem um padrão característico.

o rio Mulungu-Amargoso se constitui assim na ültima drena gem que conduz águas desde as rochas cristalinas de sul até a costa atlântica norte, pois deste rio atē o riacho do cabelo, a zona de contacto entre os sedimentos da Formação Açu e os calcä rios da Formação Jandaira na ārea da Serra Verde propriamenté dita e Serra da Macambira - Setor E-W - (item 3.1), se impõe co mo eixo divisor das äguas superficiais. Assim, a partir do rio Mulungu-Amargoso temos uma drenagem paralela, constituida por rios de curto pexcurso e que jä nascendo dentro da Bacia, condu zem ăguas para a costa norte. Em oposição a esta se estabelece 
uma densa drenagem com linhas muito curtas, que com as cabecei ras naquele divisor, dirigem-se obsequentemente para sul, e que atravessando a estrelta faixa de afloramento da Formação Açu, levam suas ãguas até o vale do rio Cearä-Mirim, de direção $E-W$. Este vale, esculpido em rochas cristalinas, constitui então um verdadeiro coletor que, captando essas äguas, as conduz para a costa leste.

Na porção sudoeste desse macłço, entre a serra verde e a Serra Aguda instalam-se linhas de drenagem de äguas que vão atingir tambëm o litoral norte, porëm o fazem indiretamente, deslocando-se primeiramente para oeste, através do rio serra Aguda até desaguar no rio Cabugi-Mulungu-Amargoso que as conduz atë a costa norte.

Do riacho do Cabelo para leste, o terceiro setor da serra Verde (item 3.1) - região denominada Serra dos Macacos - funcio nando tambëm como divisor de águas, impõe três comportamentos para a drenagem que aqui já se apresenta instalada em vales es culpidos integralmente dentro da bacia. A norte dessas eleva ções, a drenagem è ainda subparalela e constituída por riachos ainda mais curtos que os do trecho anterior, e que se dirigem diretamente para a costa norte, tais como o riacho Parazinho, dos Angicos e outros; segue-se uma drenagem para nordeste para a Lagoa do Boqueirão (riacho de Touros); para leste, atravēs do rio Tatu (ou rio das Piranhas), riacho seco e riacho da América, formadores do rio Maxaranguape que daqui já leva perenemente suas äguas atẻ a costa leste.

Algumas äreas com drenaģem endorrêica podè ser encontra das tanto no Estado do Ceará, na Fazenda Lagoa do Mato, à cerca de $22 \mathrm{~km}$ a nordeste de Jaguaruana, como no Estado do Rio Grande do Norte, no município de Açu, à cerca de $1 \mathrm{~km}$ a oeste do povoado de Catingueira $(16 \mathrm{~km}$ a sudoeste de Carnaubais), no município de Carnaubais, na própria Lagoa do Mato à cerca de 7 $\mathrm{km}$ a sudoeste de Porto do Mangue e no município de são Bento do Norte à cerca de $2 \mathrm{~km}$ a oeste do povoado de Jucuri.

No que diz respeito à relação entre as āguas subterrāneas e a drenagem superficial, como se pode notar atravēs das curvas isopiezomëtricas (MAPA 14) as águas do calcārio da Formação Jan daíra na porção central e oeste da Bacia, têm seu fluxo em diré 
ఢ̧ão aos vales dos principais rios :rio Apodi-Mossoró, rio Upanema-do Carmo e rio Piranhas-Açu, que embora não permitam a formação de flü xo superficial, funcionam como verdadeiros coletores, conduzin do-as, até ao oceano, provavelmente através de seus aluviões.

Maiores conhecimentos das relações entre as ãguas superfi ciais e as ăguas subterràneas no âmbito da Bacia Potiguar é dificultado pela inexistência de estações fluviométricas nos va les dos rios nesse dominio, bem como a deficiência da rede hi drometeorológica instalada na ārea. Atualmente apenas cinco es tações fluviomëtricas apresentam dados de interesse para estụ dos hidrogeológicos na Bacia potiguar: a estação de Pedra das Abelhas (Governador Dix-Dept Rosado), Açude Santa Cruz e Pau dos Ferros no rio Apodi; a estação de Jardim das Piranhas no rio Pí ranhas e a estação de Upanema, no rio Upanema - do Carmo. Dentre esses, somente os registros no rio Apodi podem ser utilizados, porēm, na avaliação da infiltração na ārea de exposição do aquí fero Açu, não se encontrando assim, postos que possam fornecer dados de interesse para o estudo do aquífero Jandaira. 


\section{HIDROMETEOROLOGIA}

\subsection{Introducão}

A apreciação dos elementos de hidrometeorologia que influen ciam no contexto geral dos recursos hidricos no domínio da Ba cia Potiguar feita a seguir, objetiva apenas apresentar, em li nhas gerais, as suas características mëdias.

A localização geográfica da Bacia Potiguar - proximidades do equador terrestre - the assegura genericamente, um clima quente. A topografia aplainada típica de chapada, a proximidade do oceano, a pluviometria irregular em intensidade, tempo e es paço, the dão ainda características climāticas típicas, que têm marcada influência no regime de alimentação dos aquíferos, tan to por infiltração direta das ăguas pluviais como por infiltra Ção das āguas escoadas pelos rios.

\subsection{Pluviometria}

As chuvas se constituem na ünica forma de precipitação de äguas meteōricas na ārea de dominio da Bacia Potiguar. Estas se apresentam com grande variação na distribuição temporal e espa cial, e variam ainda na quantidade anual em um mesmo local. o mapa de isoietas elaborado pelo IPT (1982) apresenta as mëdias pluviométricas anuais relativas ao período 1933-1978 (FIGURA 3). A partir da observação daquele mapa pode-se notar, que hã gran de distinção de valores entre as extremidades leste e oeste da área. Assim, utilizando-se o método das isoietas podemos distin guir três regiōes com médias pluviomētricas distintas, conforme apresentadas no QUADRO 1 a seguir.

\begin{tabular}{|c|c|c|c|}
\hline \multirow{2}{*}{ Região } & \multirow{2}{*}{ Area de Dominio } & \multicolumn{2}{|c|}{$\begin{array}{c}\text { Pluviosidade }(\mathrm{mm} / \mathrm{a}) \\
(1933-1978)\end{array}$} \\
\hline & & Intervalo & Média \\
\hline Oeste & Rio Jaguaribe atē Hipölito & $550-750$ & 650 \\
\hline Central & Hipólito até JandaIrra & $500-550$ & 525 \\
\hline Leste & Jandaĩra atë Touros & $550-900$ & 725 \\
\hline & & dia Geral & 633 \\
\hline
\end{tabular}

QUADRO 1 - Pluriometria anual média na Bacia Potiguar 


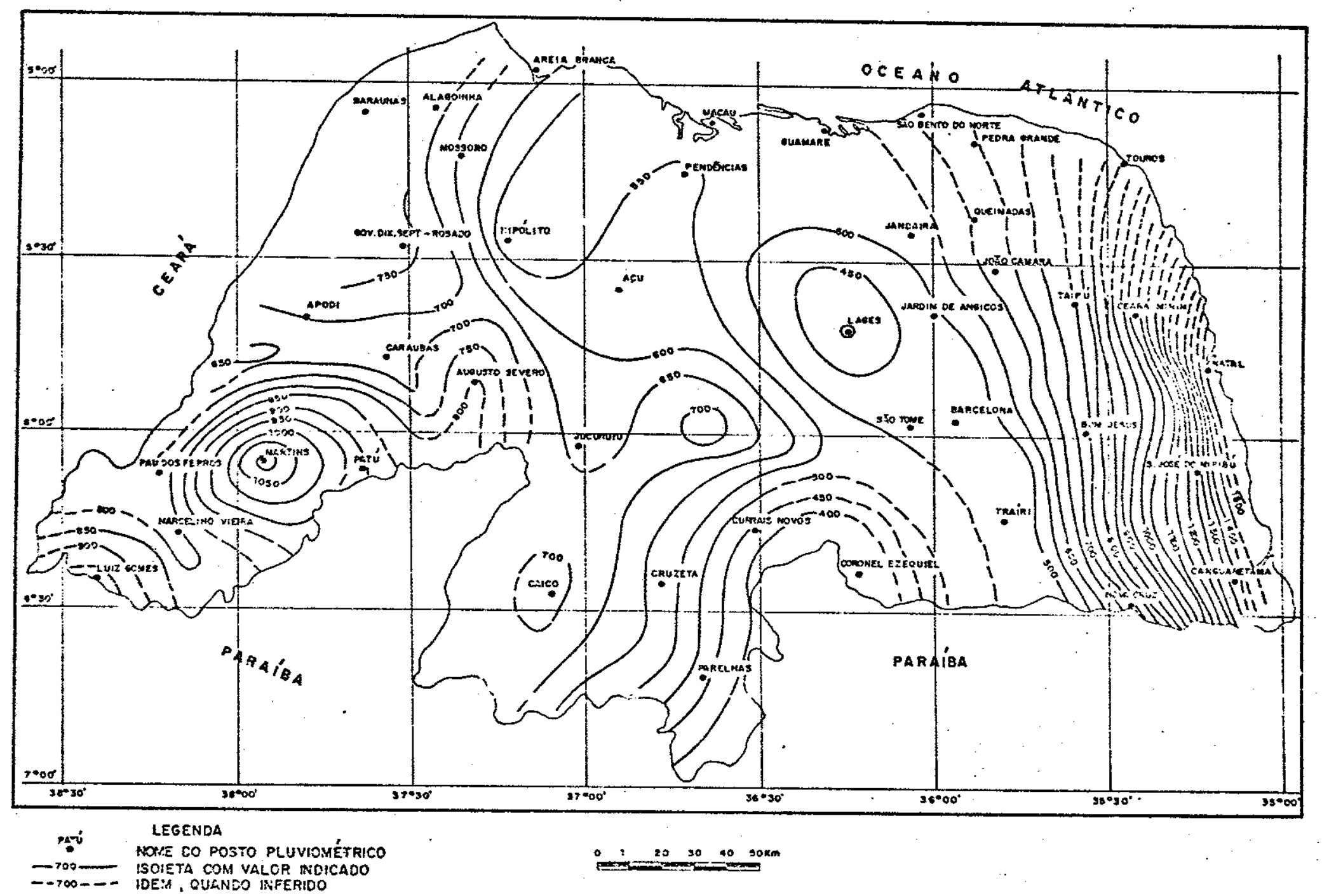

FIgURA 3 - Mapa de isoietas do Estado do Rio Grande do Norte 
- regime pluviomētrico anual evidencia a existência de uma estação chuvosa e uma estação seca, bem distintas. Na parte oes te da Bacia, o período chuvoso se inicia em fevereiro e vai até maio, ao passo que no extremo leste as chuvas costumam ter dis tribuição mais regulax no tempo e se estendem até julho.

A estiagem mais rigorosa ocorre nos meses de outubro e no vembro, podendo atingir 7 a 8 meses, na região oeste e central, e 5 a 6 meses na faixa da costa leste (REBOUÇAs et alii, 1967).

\subsection{Temperatura}

De uma maneira geral, durante todo 0 ano as temperaturas permanecem elevadas, fato caracteristico do nordeste brasilei ro. No final da estação chuvosa, ou seja, durante os meses de julho e agosto, geralmente ocorre um decréscimo da temperatura. Semelhantemente à pluviosidade, as temperaturas variam diferen temente nos extremos ocidental e oriental da bacia. O QUADRO 2 a seguir, resume os dados de temperaturas anuais mëdias de algu mas estações instaladas no seu domínio.

\begin{tabular}{|c|c|c|c|c|c|c|c|c|c|c|c|c|c|c|c|}
\hline ESTAÇDO & $\begin{array}{l}\text { PERIODO } \\
\text { EE } \\
\text { CESENVCSO }\end{array}$ & 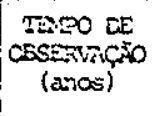 & $J$ & $F$ & $y$ & $\underset{\mathrm{A}}{\mathrm{TENP}}$ & $\frac{\operatorname{Rint}}{M}$ & as: & ENSAI & $\underset{A}{M E D}$ & S & $\left.{ }^{\circ} \mathrm{C}\right)$ & $\mathrm{N}$ & D & A \\
\hline Aq̧u & $\begin{array}{l}1964 / 66 \\
1967 / 77\end{array}$ e & 12,9 & 29,0 & 28,8 & 28,3 & 27,7 & 27,6 & 26,9 & 26,4 & 27,5 & 27,6 & 28,3 & 28,3 & 28,8 & 27,9 \\
\hline Apodit & $1963 / 77$ & 25,0 & 29,1 & 28,8 & 27,9 & 27,4 & 27,3 & 26,8 & 26,5 & 27,4 & 28,4 & 29,2 & 29,3 & 29,2 & 28,1 \\
\hline Nacau & $\begin{array}{l}1937 / 47 \\
2962 / \hat{0} 3\end{array}$ & 13,0 & 27,4 & 27,7 & 27.6 & 27,5 & 27,5 & 27,0 & 26,7 & 26,8 & 27,0 & 27,0 & 26,8 & 27,2 & 27,2 \\
\hline Nossoró & $1970 / 77$ & 8,0 & 28,2 & 27,6 & 27,3 & 26,9 & $<0,6$ & 26,4 & 20,4 & 27,1 & 27,7 & 28,2 & $28,$. & 28,6 & 27,4 \\
\hline Natal & $1912 / 67$ & & - & - & - & - & - & - & - & - & - & - & - & - & 26,0 \\
\hline
\end{tabular}

QUADRO 2 - Temperaturas mensais mëdias na Bacia potiguar (DNOS, 1969 e DNOCS, 1978).

\subsection{Insolação}

Na ärea de domínio da Bacia potiguar não há postos com pe ríodo longo de observação - a única sērie longa de registros de insolação é a de Natal, fora portanto da ārea da bacia. No QUA DRO 3 a seguir são apresentados os dados de insolação de dois 
postos na ärea de estudo. De uma maneira geral, para a maior parte da ärea da bacia os meses mais insolados são outubro e novembro.

\begin{tabular}{|c|c|c|c|c|c|c|c|c|c|c|c|c|c|c|}
\hline \multirow{2}{*}{ ESTAÇÃO } & \multirow{2}{*}{$\begin{array}{l}\text { PERIODO } \\
\text { OBS. }\end{array}$} & \multirow{2}{*}{$\begin{array}{l}\text { TEMPO } \\
\text { OBS. } \\
\text { (anOS) }\end{array}$} & \multicolumn{11}{|c|}{ INSOLAÇÃO MENSAL MEDIA (h/d) } & \multirow{2}{*}{$\begin{array}{l}\text { MEDIA } \\
\text { ANCAAL }\end{array}$} \\
\hline & & & F & M & A & M & $\mathrm{J}$ & $J$ & A & S & 0 & $\mathrm{~N}$ & D & \\
\hline $\begin{array}{l}\text { Apodi } \\
\text { Mossorō }\end{array}$ & $\begin{array}{l}1963 / 77 \\
1970 / 77\end{array}$ & $\begin{array}{r}15 \\
8\end{array}$ & $\begin{array}{ll}7,7 & 7,5 \\
7,2 & 6,0\end{array}$ & $\begin{array}{l}7,2 \\
6,2\end{array}$ & $\begin{array}{l}7,1 \\
6,1\end{array}$ & $\begin{array}{l}7,6 \\
7,0\end{array}$ & $\begin{array}{l}7,8 \\
7,0\end{array}$ & $\begin{array}{l}7,8 \\
7,5\end{array}$ & $\begin{array}{l}9,3 \\
8,7\end{array}$ & $\begin{array}{l}9,5 \\
9,2\end{array}$ & $\begin{array}{l}9,7 \\
9,5\end{array}$ & $\begin{array}{l}9,4 \\
9,4\end{array}$ & $\begin{array}{l}8,7 \\
9,4\end{array}$ & $\begin{array}{l}8,2 \\
7,6\end{array}$ \\
\hline ivatal & $\begin{array}{l}1912 / 42 \\
1961 / 67\end{array}$ & $\begin{array}{r}31 \\
7\end{array}$ & $\begin{array}{ll}8,3 & 7,1 \\
8,8 & 7,6\end{array}$ & $\begin{array}{l}7,3 \\
7,5\end{array}$ & $\begin{array}{l}6,7 \\
6,5\end{array}$ & $\begin{array}{l}6,8 \\
7,3\end{array}$ & $\begin{array}{l}6,6 \\
6,8\end{array}$ & $\begin{array}{l}7,1 \\
6,8\end{array}$ & & $\begin{array}{l}9, \\
8,\end{array}$ & 9, & $\begin{array}{l}9,9 \\
9,5\end{array}$ & $\begin{array}{l}9,3 \\
9,6\end{array}$ & $\begin{array}{l}8,0 \\
3,0\end{array}$ \\
\hline
\end{tabular}

QUADRo 3 - Insolação mensal média na Bacia Potiguar - (DNOS, 1969 e DNOCS, 1978).

\subsection{Ventos}

Os ventos dominantes na àrea são os alísios de sudeste, que constituem a massa equatorial atlântica, ocorrendo secundaria mente os ventos de nordeste e de leste. Em Natal, as velocida des variam de 3,9 a $4,9 \mathrm{~m} / \mathrm{s}(1913 / 33)$, sendo agosto o mês vento so e março-abril o períođo de maior calmaria. Em Cruzeta, . no centro-sul do Estado do Rio Grande do Norte, já fora do domínio da bacia, variam de 1,2 a $3,0 \mathrm{~m} / \mathrm{s}(1930 / 42)$ (DNOS, 1969). Nota-se assim, uma sensivel redução da intensidade dos ventos, com - afastamento do litoral.

o QUADRO 4 a seguir, fornece a velocidade média dos ventos em algumas estações no interior da Bacia Potiguar.

\begin{tabular}{|l|c|c|c|}
\hline \multirow{2}{*}{ Estação } & \multicolumn{3}{|c|}{ Ventos e suas Velocidades Médias (m/s) } \\
\cline { 2 - 4 } & SE & NE & E \\
\hline Mossoró & 3,6 & 4,6 & 4,0 \\
Apodi & 5,6 & 4,8 & 4,1 \\
Macau & 6,9 & 5,6 & 5,4 \\
\hline
\end{tabular}

QUADRO 4 - Velocidade mëdia de ventos na Bacia Potiguar, (DNOCS, 1978).

\subsection{Umidade Relativa do Ar}

Os valores mäximos de umidade relativa do ar ocorrem nos. meses de abril e maio, e os valores minimos nos meses de outụ 
bro e novembro. O QUADRO 5 a seguir, apresenta valores da umida de relativa em algumas estações meteorológicas na Bacia Potí guar. Pode-se observar a diminuição dos teores de umidade com a interiorização das estações.

\begin{tabular}{|c|c|c|c|c|c|c|c|c|c|c|c|c|c|c|c|}
\hline POSTO & $\begin{array}{c}\text { PERIODDO } \\
\text { DE } \\
\text { OBSERVIFCADO }\end{array}$ & $\begin{array}{l}\text { TEVPO DE } \\
\text { OBSERVACAO } \\
\text { (ar:OS) }\end{array}$ & $\mathrm{J}$ & $F$ & M & $\underset{A}{\operatorname{ATDADE}}$ & $\frac{\mathrm{RET}}{\mathrm{MT}}$ & IVA & $\underset{\mathrm{J}}{A R D}$ & $\begin{array}{c}\text { NSAL } \\
\text { A }\end{array}$ & $\begin{array}{r}\mathrm{SDIA} \\
\mathrm{S}\end{array}$ & 0 & $\mathrm{~N}$ & D & $\begin{array}{l}\text { MEDIA } \\
\text { ANULL } \\
\text { (8) }\end{array}$ \\
\hline Apodi & $1963 / 77$ & 15 & 67,0 & 71,0 & 78,0 & 80,0 & 76,0 & 73,0 & 68,0 & 63,0 & 59,0 & 59.0 & 59,0 & 62,0 & 68,0 \\
\hline Mossoró & $1970 / 77$ & 8 & 69.0 & 76,0 & 81,0 & 81,0 & 78,0 & 74,0 & 71,0 & 63,0 & 61,0 & 62,0 & 65,0 & 65,0 & 70.0 \\
\hline Macau & - & - & 69,0 & 72,0 & 73,0 & 74,0 & 70,0 & 67,0 & $\epsilon 6,0$ & 64,0 & 64,0 & 65,0 & 62,0 & 67,0 & 68,0 \\
\hline Natal & $1913 / 67$ & 45 & 79,5 & 76,0 & 76,0 & 80,2 & 20,9 & 81,3 & 80,9 & 78,4 & 76,2 & 74,6 & 74,8 & 79,5 & 77,3 \\
\hline Cruzetaic) & $1930 / 42$ & 13 & 61,0 & 65,0 & 69.0 & 70,0 & 67,0 & $66, i$ & 62,0 & 59,0 & 56,0 & 55,0 & 55,0 & 57,0 & 62,0 \\
\hline
\end{tabular}

(a) Fora do comirio, porëm pröxira do Inite da Bacia Potiguar

QUADRO 5 - Valores mensais médios de umidade relativa do ar na Bacia Potiguar (DNOS, 1969 e DNOCS, 1978).

\subsection{Evaporação e Evapotranspiração}

No QUADRO 6 a seguir, são apresentados os valores de evapo ração potencial em algumas estações meteorológicas da Bacia Po tiguar medidas através de Tanque Tipo "A" do "United States Weather Bureau" ou através de Evaporimetro pichē.

\begin{tabular}{|c|c|c|c|c|c|c|c|c|c|c|c|c|c|c|c|c|}
\hline \multirow[t]{2}{*}{ ESTACAO } & \multirow[t]{2}{*}{$\begin{array}{l}\text { DERIONO } \\
\text { DE OES. }\end{array}$} & \multirow[t]{2}{*}{$\begin{array}{l}\text { TEMPO LE } \\
\text { CBS IAnOS) }\end{array}$} & \multirow[t]{2}{*}{ TIPO TE } & \multicolumn{12}{|c|}{ 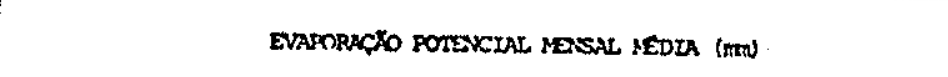 } & \multirow{2}{*}{$\begin{array}{l}\text { SEDIA } \\
\text { ANURLL } \\
\text { (mti) }\end{array}$} \\
\hline & & & & $\mathbf{J}$ & $\boldsymbol{F}$ & M & A & $\cdot M$ & 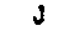 & J & A & $\mathbf{s}$ & 0 & $N$ & 0 & \\
\hline \multirow[t]{2}{*}{ Apodit } & $1965 / 77$ & 13 & $\begin{array}{l}\text { Tanque } \\
\text { Classe A (1) }\end{array}$ & 291,2 & 23. 8 & $\therefore-8$ & 182.8 & 36,5 & 177,0 & $20 \% 5$ & 26.1 & 299,6 & 327,0 & 315,6 & 316,3 & 3006,3 \\
\hline & $1963 / 77$ & 15 & Piche & 203,0 & 135.1 & 98,7 & 90,2 & 108,6 & 116,1 & 149,7 & 215,7 & 241,2 & 250,5 & 259,4 & 244,3 & 2111.0 \\
\hline Mossoró & 1970/77 & 8 & Piche & 177,3 & 240,5 & 95,2 & 79,7 & 78,5 & 215,7 & 149,7 & 221,8 & 238,3 & 233,9 & 224,4 & 231,2 & 1976,2 \\
\hline Yacau & anos & 24 & Plche & 222,0 & 179,0 & 187,0 & 170,0 & 201,0 & 223,0 & 244,0 & 287,0 & 275.0 & 272,0 & 238,0 & 232,0 & 2730,0 \\
\hline Natal & (a) & 55 & & 204,0 & 178,0 & 268,0 & 234,0 & 127,0 & 114,0 & 121,0 & 150,0 & 180,0 & 216,0 & 214,0 & 215,0 & 2021.0 \\
\hline \multirow{3}{*}{ Apodi } & (b) & 27 & & 173,0 & 251,0 & 148,0 & 125,0 & 114,0 & 109,0 & 119,0 & 138,0 & 170,0 & 194.0 & 189,0 & 286,0 & 1316,0 \\
\hline & & & $\begin{array}{c}\text { Hargreaves } \\
\text { i2: }\end{array}$ & 187,0 & 156,0 & 144,0 & 122,0 & 126,0 & 121,0 & 239,0 & 168,0 & 187,0 & 206,0 & 201,0 & 194,0 & 1951,0 \\
\hline & & & Relaçäo(2)/(2) & 0,64 & 0.67 & 0.66 & 0,66 & 0,77 & 0,68 & 0,68 & 0,64 & 0,63 & 0,63 & 0,64 & 0,62 & 0,65 \\
\hline
\end{tabular}

(a) avos (1913/67)

(b) STLEN (1912/27, 2921/22 e 1924/42)

QUADRO 6 - Evaporação potencial mensal média na Bacia Potiguar

A evapotranspiração tem sido correlacionada com a evapora ção obtida em tanque classe "A" do "United States Weather Bureau" e vārias equações têm sido formuladas para se efetuar o cál. culo da evaporação e da evapotranspiração a partir de dados cli māticos. 
REBOUÇAS et alii (1967) calcularam a evapotranspiração po tencial para sete estações na Bacia potiguar (Açu, Apodi, João Câmara, Macaíba, Macau, Mossoró e Natal) pela aplicação da equa Ção de Turc e notaram que a mesma varia pouco no domínio da bâ cia, sendo em mëdia, da ordem de $1500 \mathrm{~mm} / \mathrm{a}$, apresentando maior intensidade no período de setembro a dezembro.

- DEPARTAMENTO NACIONAL DE OBRAS CONTRA AS SECAS-DNOCS (1978), calculou a evapotranspiração potencial para o posto de Apodi, pelo método de Hargreaves, obtendo o valor de $1951 \mathrm{~mm} / \mathrm{a}$ e uma relação média de 0,65 entre os valores de evapotranspira ção calculados por esse mëtodo e os valores encontrados pelas medições em tanque tipo "A".

\section{$4.8 \quad$ Clima}

REBOUÇAS et alii (1967), baseando-se na classificação bio climática de Gaussen que se fundamenta na evolução das tempera turas e nas precipitações no decorrer do ano, identificaram a existência de duas äreas com climas distintos. Na primeira de las, a oeste do meridiano de $36^{\circ}$, predomina um clima do tipo tro pical quente, com período seco acentuado. Na outra ārea, situa da a leste do mesmo meridiano, predomina um bioclima nordestino quente, com período seco mëdio.

Ainda segundo esses autores, pela classificação climātica de De Martonne, que se baseia no indice de aridez, na porção a oeste do meridiano de $36^{\circ}$, o Indice de aridez é supertor a 20 e na porção central da Bacia, porëm o indice é inferior a 15, o que a torna integrante da região mais ärida do nordeste (FIGURA 4). Para leste desse meridiano, o Indice de aridez varia entre 20 e 40, refletindo um grau de umidade mais elevado. De Natal para sul, jä na Bacia Pernambuco-Paraíba, os valores de umidade são ainda mais elevados, integrando-se esta ärea na denominada zona ümida do nordeste.

Pela classificação climātica de köppen a porção oeste e central da Bacia Potiguar (FIGURA 5) se situa na categoria de clima BSw'h'; uma estreita faixa mais oriental da porção cen tral, na categoria BS' 'h' e a porção leste, na categoria As.

As letras têm a significação conforme segue: 


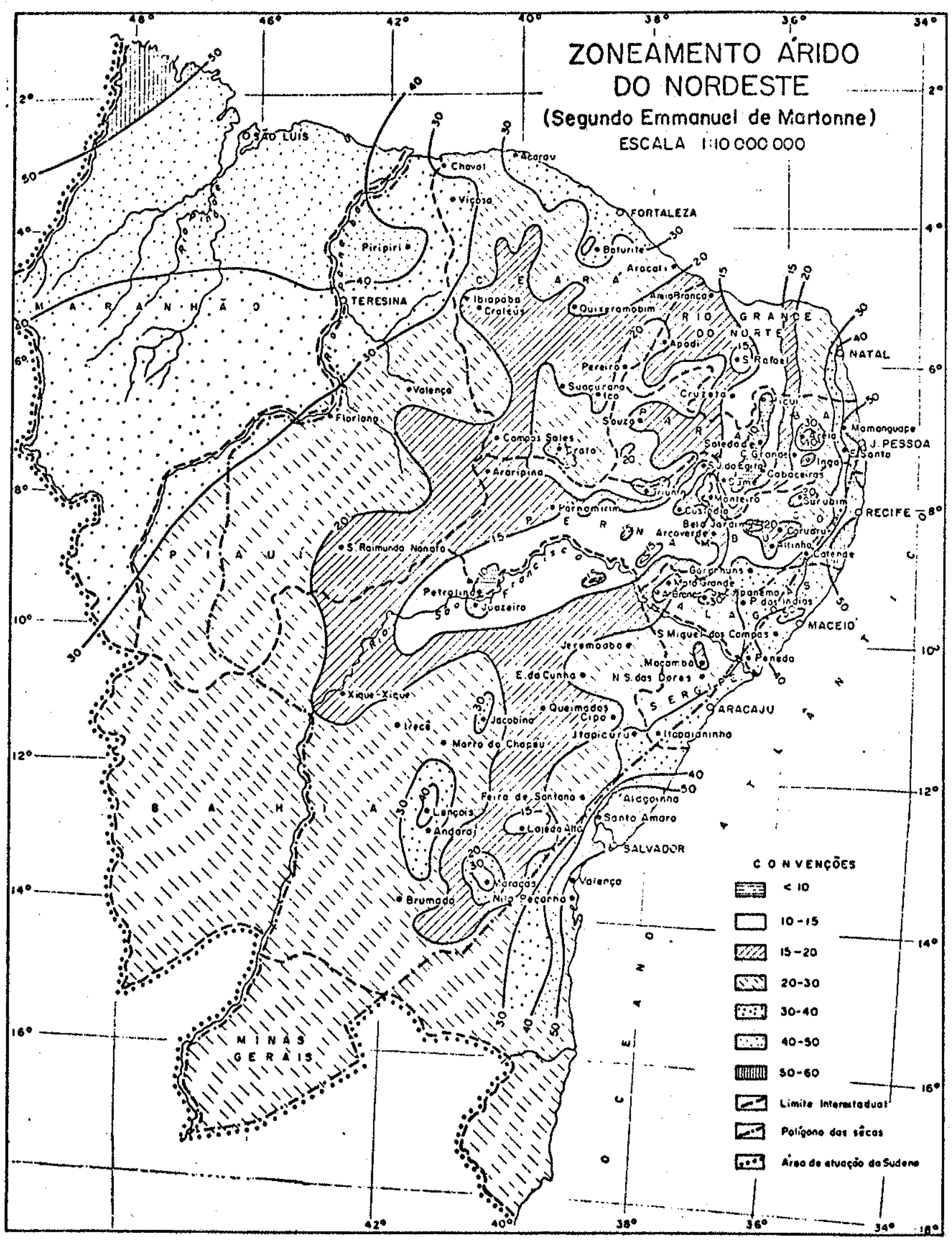

FIGURA 4 - Zoneamento climätico do Nordeste, segundo de Martonne (Rebouças, 1967). 
B - os climas do Grupo B são secos. A evaporação anual mēđia é maior do que a precipitação anual média. Não hã excedente de ăgua e portanto a pluviosidade não è suficiente para for mar correntes perenes:

S - clima de estepe. Clima do Grupo B, porēm do tipo semi-ärido, caracterizado na Bacia Potiguar pelas precipitações anuais minimas da ordem de 600-700 mm, havendo uma época chuvosa bem distinta (periodo de janeiro a maio);

A - clima tropical chuvoso. A temperatura média è superior a $18^{\circ} \mathrm{C}$ durante todo 0 ano. A precipitação anual é abundante e excede à evaporação;

h - clima do tipo B. Clima quente e seco, onde a temperatura mé dia anual se mantêm superior a $18^{\circ} \mathrm{C}$;

$h^{\prime}$ - clima muito quente;

s - as chuvas ocorrem no inverno. Verão seco. A altura da chuva no mês mais úmido no inverno deve ser no mínimo o triplo da altura da chuva no mês mais seco do verão;

s' - as chuvas de inverno são antecipadas para o outono;

$w^{\prime}$ - as chuvas de verão são retardadas para o outono. 


\section{SEMVO DE MEOEOPOOGA}

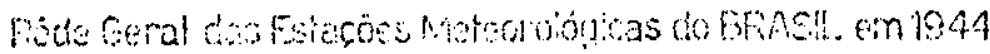

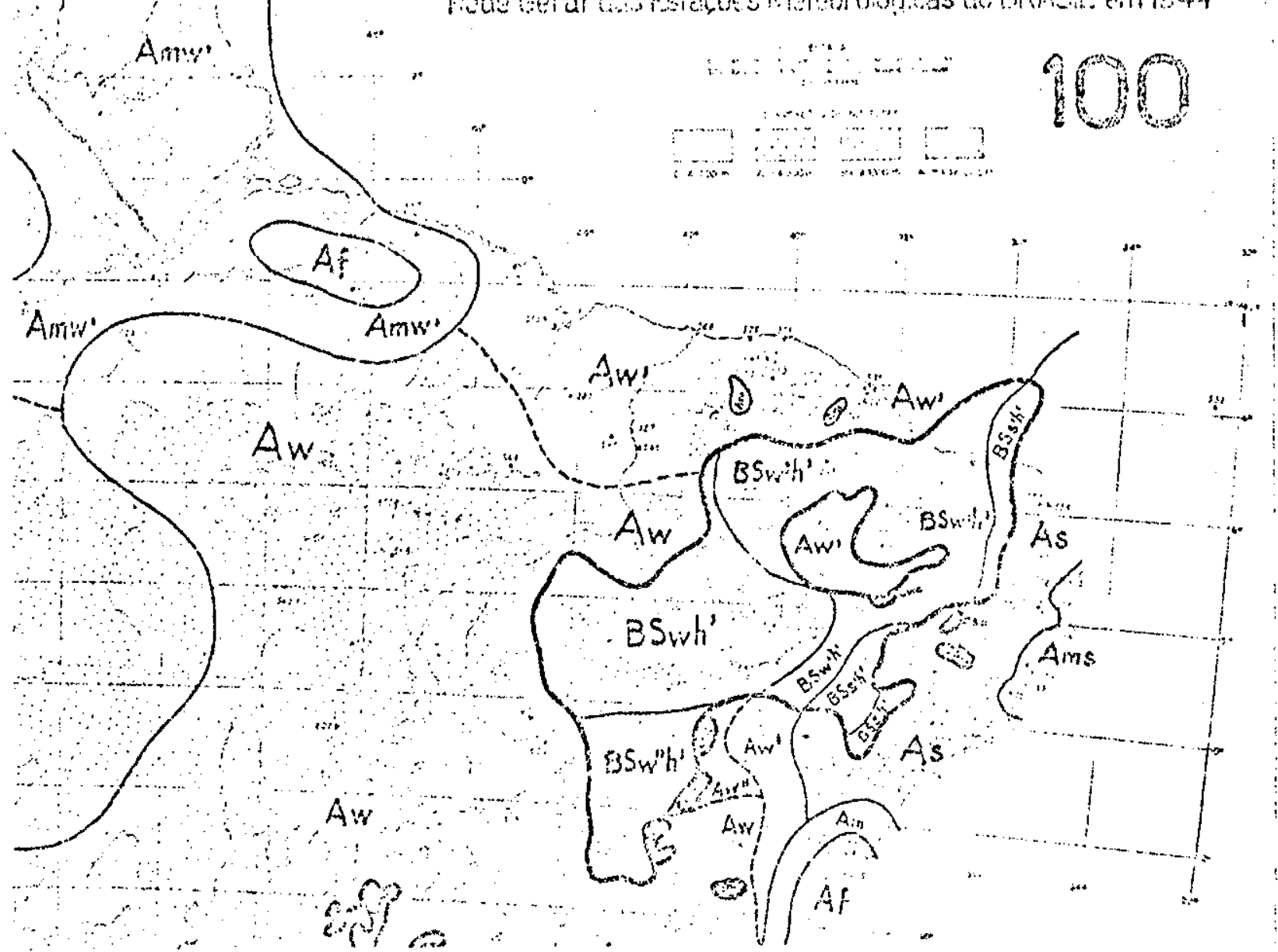

FIGURA 5 - Zoneamento climätico do nordeste (parcial) segundo KOPPEN (Ministërio da Agricultura, 1969). 


\section{SINTESE GEOLOGICA DA BACIA POTIGUAR}

\subsection{Introdução}

Desde o final do sēculo XIX diversos pesquisadores têm es tudado a geologia da bacia potiguar. Esta sintese porém teve suas bases nos trabalhos publicados por SAMPAIO \& SCHALLER (1968), CYPRIANO \& NUNES (1968), MANOEL FILHO (1971), ARAOJO et alii (1978), MENOR et alii (1980) e SOUZA (1982). A geologia da área estudada é apresentada no MAPA 3.

\subsection{Arcabouco Estrutural}

Segundo CYPRIANO \& NUNES (1968) a Bacia Potiguar é resul tante de um tectonismo relativamente brando, que durante um pro cesso continuo de distensão crustal gerou uma calha em pericli nal com eixo mergulhando suavemente para NE. Em sua parte leste, uma ārea mais rasa forma um homoclinal E-W com mergulhos suaves para $\mathrm{N}$.

Conforme SOUZA (1982), o arcabouço estrutural da Bacia é decorrente de falhamentos normais ocorridos durante o cretáceo inferior, quando se desenvolveu o "rift" que precedeu à abertú ra do Oceano Atlântico. Hä dois sistemas de falhamentos princi pais: um de direção SW-NE e outro NW-SE (FIGURA 6).

$\mathrm{Na}$ porção emersa da Bacia Potiguar destacam-se duas gran des estruturas orientadas segundo a direção SW-NE, sub-parale las, que divergem a nordeste; a localizada a norte é denominada Falha de Areia Branca, e a localizada a sul, Falha de Carnau bais (FIGURA 6).

Na porção submersa da Bacia, as falhas têm direção prefe rencial NW-SE e E-W, modelando o contorno da costa, entre as quais se destaca a Falha de Ubarana (ARAUJo et alii, 1978).

No presente estuđo considera-se uma compartimentação estru tural da Bacia Potiguar em três blocos, correlacionada com a compartimentação apresentada por CYPRIANo \& NUNEs (1968) a sa ber: Bloco oeste (Plataforma oeste); Bloco Central e Bloco Leste (Plataforma Leste).

A Plataforma oeste se constitui em uma monoclinal com mer gulho da ordem de $2^{\circ}$ para S-SE, em direção ao centro da Bacia. E limitada a norte pela linha de costa modelada pelos falhamen 


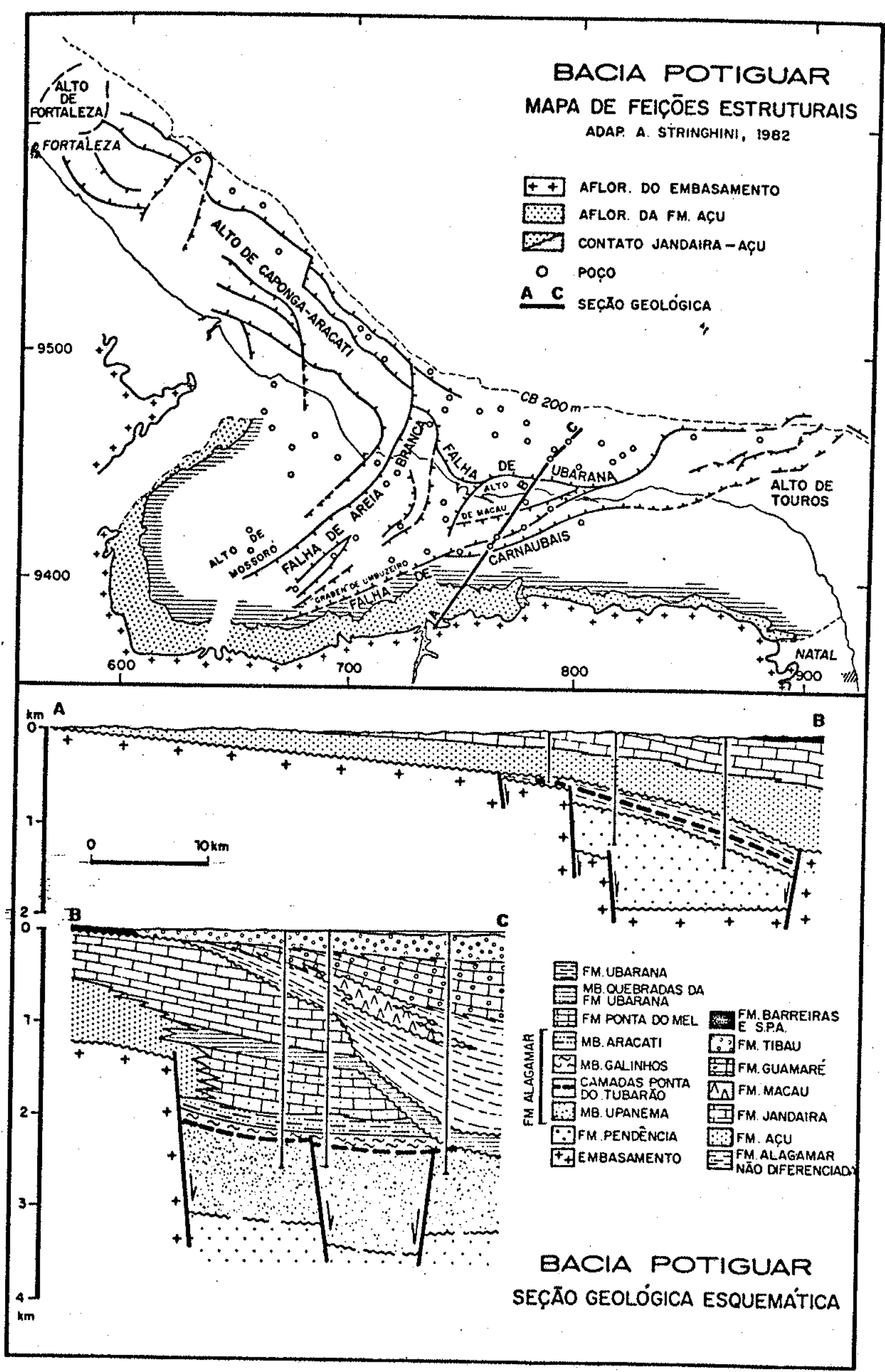

FIGURA 6 - Arcabouço estrutural da Bacia Potiguar (SOUZA, 1982). 
tos NW-SE; a oeste e sudoeste pelo embasamento cristalino e a S-SE, pela Falha de Areia Branca, alinhada ao longo do Rio Apo di. Incluídos na Plataforma oeste está a estrutura denominada Alto de Mossoró, a oeste da Falha de Areia Branca.

A Plataforma leste, tambëm monoclinal, apresenta mergulhos suaves e generalizados para $\mathrm{N}-\mathrm{NW}$, com exceção do extremo leste, que mergulha para NE (Região de Touros) e depois para E (Região de Maxaranguape). E limitada a oeste e a noroeste pela Falha de Carnaubais, que vai desde as proximidades de Upanema até a foz do rio Camurupim; a nordeste e a leste, pela linha de costa, e a sul, desde upanema até João Câmara, pelo embasamento cristali no. Aqui destaca-se o Alto de Touros, já no extremo leste da Bă cia.

- Bloco central era tido como "graben" ünico (CYPRIANO \& NUNES 1968), porém điante de novos conhecimentos, ARAUjo et alii. (1978) o consideram como uma série de pequenos " "grabens" e "horsts". Corresponde à porção mais profunda da Bacia potiguar na sua parte emersa. A maior profundidade do embasamento foi atingida no poço da petrobrăs 1-QB-RN (Poço Quixaba no 1, Rio Grande do Norte), com $2171 \mathrm{~m}$.

No dominio do Bloco Central são identificadas duas regiões que se constituem em altos estruturais relativos: Alto da Quixa ba e Alto de Macau.

Todas as estruturas citadas estão relacionadas ao evento tectônico responsāvel pela gênese da bacia e admite-se que es ses falhamentos foram atuantes até o inicio da deposição da For mação Jandaíra, quando então a Bacia adquiriu relativa estabili dade (ARAOJO et alii, 1978).

Hä ainda estruturas superimpostas à sedimentação cretácea, de orientação geral NW-SE, associadas ao novo esforço tracio nal responsável pelos derrames basälticos terciārios (SIAI, 1975). Esses lineamentos são mais frequentemente observados na porção intermediāria da bacia, entre Mossoró e Jandaira, onde impõem a sua oxientação a riachos e córregos (MAPAs 2 e 3 ).

Ainda permanece indefinido um eventual limite, na area nor deste do Estado do Rio Grande do Norte, que venha a separar a sequência cretācea da Bacia Potiguar, dos seus possiveis corres pondentes ainda pouco conhecidos na Bacia Pernambuco-paraíba. 
Admitimos no entanto, apenas para efeito desta monografia, esse limite passando entre Pureza e Cearä-Mirim, onde a con tinuidade dos afloramentos da Formação Jandaira é interrompida e também porque, para leste da Lagoa do Boqueirão, os aquíferos Jandaí ra e Açu cedem lugar à grande potencialidade do aquífero Barrei ras (item 7.1 ).

\subsection{Iitoestratigrafia}

o pacote de sedimentos da Bacia Potiguar é constituído por camadas de idade cretācea e terciäria, sobrepostas às rochas me tamörficas e ígneas do embasamento pré-cambriano, através de contato discordante. A FIGURA 7 apresenta esquematicamente a 1 i toestratigrafia da Bacia Potiguar proposta por SoUzA (1982) cal cada na atualização da coluna estratigräfica publicada por ARAGJO et alii (1978) e que é sucintamente descrita nos itens que se seguem.

\subsubsection{Formação Pendência}

Nome e histórico: uma seção não aflorante, composta por conglomerado, arenito, siltito e folhelho que recobre o embasa mento cristalino nas partes mais profundas da bacia, foi inicial mente denominada de Formação Gangorra por SAMPAIO \& SCHALLER (1968) e posteriormente ARAUJO et alii (1978) utilizaram infor malmente a denominação de Formação Pendência para a mesma, nome de uma cidade situada na margem direita do Rio Açu no Rio Gran de do Norte.

Litologia: è constituída predominantemente por folhelhos micāceos cinza mēaio a escuro, com intercalações de siltitos cinza médio a claro e arenitos cinza esbranquiçados, muito finos a médios, calciferos, podendo ainda ocorrer conglomerados junto às falhas, como por exemplo junto à Falha de Carnaubais.

Comportamento estratigräfico: sua ocorrência se limita ao preenchimento do "graben" central, não sendo conhecidos aflora mentos. Assenta-se discordantemente sobre as rochas do embasa mento cristalino e o contacto superior é tambëm discordante com a Formação Alagamar.

Segundo souzA (1982), na ārea emersa a sua maior espessura constatada é de $1100 \mathrm{~m}$ e a mäxima è estimada em torno de $3000 \mathrm{~m}$. 


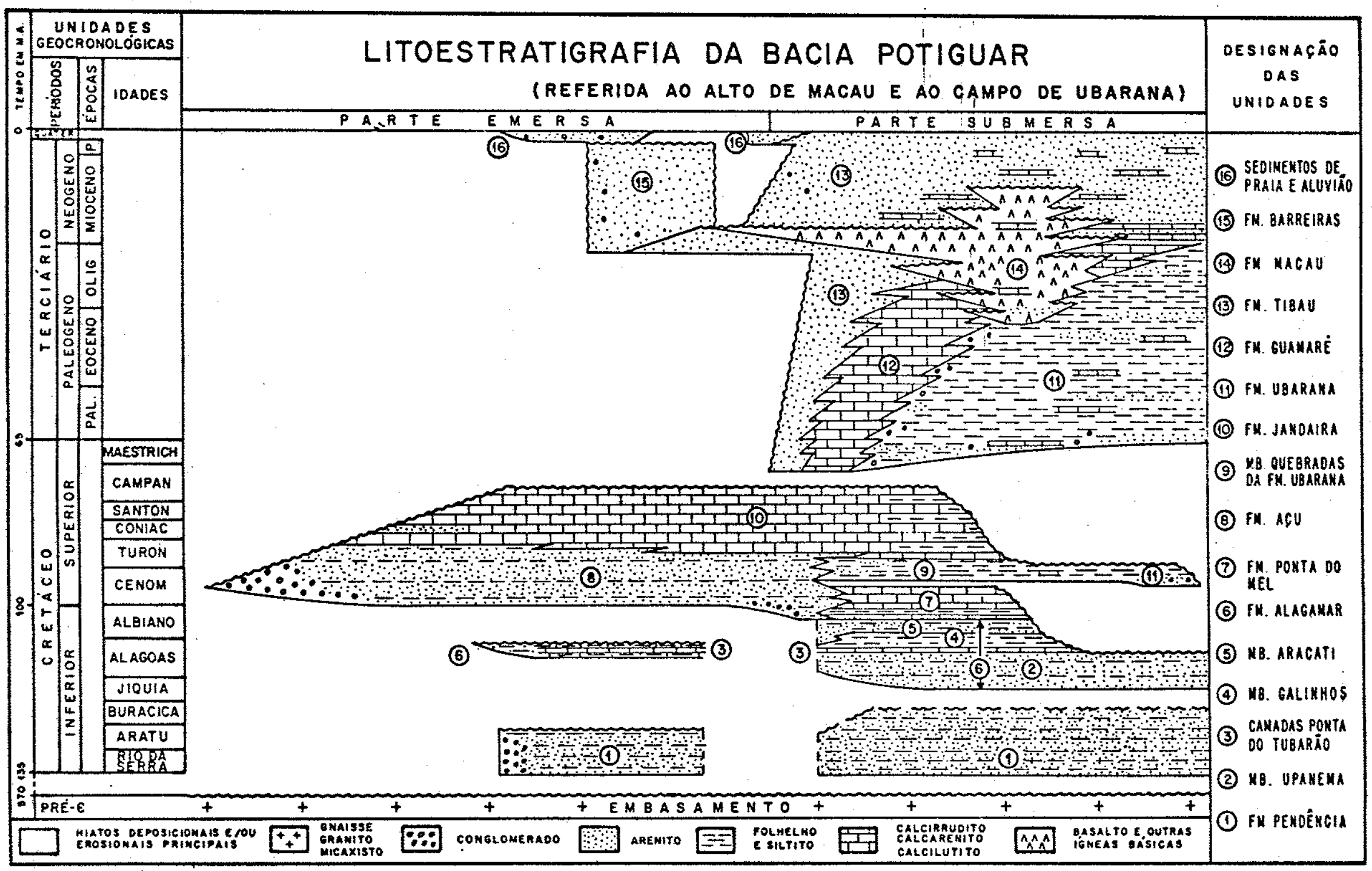

FIGURA 7 - Litoestratigrafia da Bacia Potiguar (SOUZA, 1982). 
Na ärea norte onde o mapeamento sismico é precārio e os poços não atravessam a unidade, é difícil estimar a sua espessura. Na parte submersa da bacia, nobloco baixo da Falha de Ubarana, a sua espessura é estimada em 3000 a $3.500 \mathrm{~m}$.

Ambiente deposicional: a sua deposição se deu em leques del taico-lacustres, em pronunciada subsidência (ARAOJO et ali 1978).

Idade: a idade da Formação Pendência é Rio da serra e Ara tu (REGALI \& GONZAGA, 1982 "apud" SOUZA, 1982). Segundo SouZA, "ibidem", na porção submersa da Bacia podem existir sedimentos de Idade Buracica (?) a Jiquiá (?).

\section{$\underline{5.3}$ Formação Alagamar}

Nome e Histórico: o nome desta unidade provém da Ilha de Alagamar, situada no litoral do Rio Grande do Norte. ARAUJO et alii (1978) a incluíram na Formação Açu e SouzA (1982) porēm a destaca como unidade à parte, por apresentar características 1 i tológicas prōprias. A Formação Alagamar é subdividida no Membro Upanema, Camadas Ponta do Tubarão, Membro Galinhos e Membro Ara cati.

Litologia: o membro Upanema è predominantemente arenoso, com intercalações de calcário e folhelho. As camadas ponta do Tubarão são constituidas por calcilutito ostracoidal intercala do com folhelho cinza esverdeado. O Membro Galinhos é essencial mente argiloso e o membro Aracati constitui-se de arenito fino a médio, às vezes grosseiros, folhelho cinza médio a escuro e cal cilutito.

Comportamento estratigräfico: a Formação Alagamar apresen ta espessuras da ordem de $1400 \mathrm{~m}$ no bloco baixo da Falha de Uba rana e raramente atinge $800 \mathrm{~m}$ na ärea sul.

o membro Upanema ocorre principalmente na ärea submersa, estando ausente no Alto de Touros e no Alto de Caponga-Aracati. As camadas Ponta do Tubarão ocorrem em quase toda a bacia, sen do que nos altos de Touros e Caponga-Aracati elas repousam dis cordantemente sobre o embasamento. Os membros Galinhos e Araca ti são bem definidos na ärea submersa ao passo que na ärea emer sa só é possível diferenciä-los em alguns poços.

A base da Formação Alagamar é discordante com a Formação 
Pendência ou com o embasamento. o contacto superior é discor dante com a Formação Açu na área emersa e concordante e transí cional com a Formação Ponta do Mel e tambēm com a Formação Ubą rana, na ärea submersa.

Ambiente deposicional: 0 ambiente de deposição foi tipica mente fluvial na parte inferior da unidade, passando a deltaicolacustre na parte superior do Membro Upanema. As camadas Ponta do Tubarão marcam o final da deposição lacustrina e os Membros Galinhos e Aracati representam um sistema deltaico com influên cia marinha (ambiente transicional).

Idade: segundo estudos palinológicos realizados por REGALI \& GONZAGA (1982) "apud" SOUZA (1982), a idade dessa unidade é Alagoas a Albiano. Segundo SOUZA, ibidem, hã possibilidades de que a parte basal do Membro Upanema seja de idade Jiquiā (presença de ostracodes).

\subsubsection{Formação Ponta do Mel}

Nome e Histórico: o nome proposto para esta unidade, TIBANA \& TERRA (1981) "apud" SOUzA (1982), è o de uma cidade situada no litoral do Rio Grande do Norte. Era anteriormente incluida na Formação Jandaíra e na parte superior da Formação Açu (ARAOJo et alii, 1978).

Litologia: na Formação Ponta do Mel destacam-se duas se ções bem distintas. A inferior possui na base, camadas de calca renito oncolitico e doloespatito, sobrepostos por arenito fino a médio. A seguir, há uma seção de calcilutito intercalado com folhelho. A seção superior è composta principalmente por calca renito bioclástico a algas vermelhas e verdes, crustosas, par cialmente recristalizado e dolomitizado, além de camadas de dó loespatito.

Comportamento estratigräfico: a Formação Ponta do Mel ocor re somente na porção submersa da Bacia. A maior espessura encon trada foi de $647 \mathrm{~m}$. O contacto superior com a Formação Ubarana ê brusco, podendo ser discordante (erosivo) ou concordante (com a presença de hiato deposicional). o contacto inferior com a Formação Alagamar è concordante e transicional.

Lateralmente, para sudoeste, esta unidade grada para a For 
mação Açu. Esta gradação que se constitui numa litozona com ca racteristicas pröprias e diferentes de ambas as formações é in formalmente designada de formação Açu-Ponta do Mel (SOUZA, 1982).

Ambiente deposicional: quanto ao ambiente deposicional se gundo TIBANA \& TERRA (1981) "apud" SOUZA (1982, a fácies predo minante é a de plataforma rasa (calcarenitos) associada a. pla nície de maré pouco desenvolvida e mar aberto (calcilutito e plantônicos).

Idade: segundo aqueles mesmos autores a deposição dessa uni dade teria ocorrido no Albiano e Cenomaniano.

\subsubsection{Formações Ubarana, Guamaré e Tibau}

As Formações Ubarana, Guamarē e Tibau originadas atravēs da deposição de clásticos e carbonatos durante sucessivas pro gradações, estão restritas à plataforma continental e proximida des da costa e que, devido ao caráter deste estudo, não apresen tam maior importância, razão pela qual serão apenas sucintamen te descritas.

Formação Ubarana

Nome, histórico e litologia: esta unidade foi definida por MAYER, 1974 "apud" SOUZA (1982) e representa a base da sequên cia regressiva. Caracteriza-se por apresentar uma seção peliti ca onde estão presentes folhelho, siltito, calcilutito, arenito, diamictito, conglomerado e as vezes, olistolitos.

o contacto inferior da Formação Ubarana com a Formação Pon ta do Mel pode ser tanto concordante como discordante (erosivo) e com a Formação Alagamar é discordante. O seu contacto supe rior com a Formação Guamarē pode ser tambëm concordante ou dis cordante.

Ambiente deposicional e idade: o ambiente deposicional è tipicamente de talude continental e planicie bacial, com a pre sença de turbiditos. A sua idade abrange o Cenomaniano (supe rior?) a Turoniano e Campaniano a oligoceno (seção regrẹsiva) (SOUZA, 1982). 
Formação Guamarē

Nome, histốrico e litologia: esta unidade foi reconhecida na Bacia desde o início de sua exploração. SouzA (1982) propôs - nome de Formação Guamaré, nome de uma cidade do litoral norte do Rio Grande do Norte, para designar uma sequência carbonätica que ocorre na plataforma continental do Rio Grande do Norte e Cearā, sobreposta principalmente à Formação Ubarana e sotoposta à Formação Tibau. E constituída de calcarenito creme acastanha do, bioclástico, em parte recristalizado e dolomitizado, com in tercalações de calcilutito, folhelho e arenito.

Comportamento estratigráfico e idade: os seus contactos com as unidades sobre e subjacentes são gradacionais ou discor dantes.ocorre intercalada com a Formação Tibau e tambëm como in tercalação dentro das Formações Macau e Ubarana. o ambiente de posicional é de plataforma carbonātica e talude carbonātico (FISCHER et alii, 1975 "apud" SOUZA, 1982). A sua deposição se deu do Campaniano ao Mioceno (REGALI \& GONZAGA, 1982, "apud " SOUZA, 1982).

Formação Tibau

Nome, histörico e litologia: unidade descrita por Kegel (1957), que a denominou de Infra-Barreiras, foi definida por CYPRIANO \& NUNES (1968) na ärea emersa, e por MAYER (1974) "apud" SOUZA (1982) na porção submersa. Sobreposta à Formação Guamarē, é constituída por arenitos quartzosos e arcosianos, médios a conglomeräticos, verde amarelado a amarelo claro, duros a fria veis, acamamento irregular localmente com deformações convolụ tas, correspondente a leques deltaicos (FISCHER et alii, 1975 "apud" SouzA, 1982). As suas exposições estão restritas a falẹ sias ao longo da costa norte e ao longo das margens dos rios Apodi, Açu e Mulungu, nos seus baixos cursos.

Comportamento estratigräfico: o seu contacto inferior na parte emersa é discordante com a Formação Jandaira e na parte submersa é concordante com a Formação Guamarẻ. o contacto supe rior com a Formação Barreiras, bem como junto aos sedimentos re centes é de difícil definição (MAYER, 1974 "apud" SOUZA, 1982). 


\subsubsection{Formação Açu}

Nome e históxico: essa unidade foi inicialmente denominada "Arenito Vermelho por OLIVEIRA \& LEONARDOS (1943) e de Basal Sandstone, por KREIDLER (1949) que em seus mapas a chamou de Arenito Açu, "apud" CYPRIANO \& NUNES (1968)". KEGEL (1957) pro pôs a divisão dessa unidade estratigräfica em três membros com transição gradacional entre eles, denominados Arenito Açu infe rior, médio e superior. SAMPAIO \& SCHAIIER adotaram a divisão em apenas dois membros, conforme anteriormente apresentada pela SUDENE (1966),"apud" SAMPAIO \& SCHALTER (1968), que ainda informalmente ado taram, sob a designação de Formação Açu, uma unidade constituída por um mem bro inferior e um superior. A seguir, CYPRIANO \& NUNES (1968) propõem formalmente a denominação de Formação Açu, cons tituída pelos membros A (superior), B (mëdio) e C (inferior).

ARAOJO et alii (1978) apresentam ainda informalmente a For. mação Açu subdividida em très membros: Membro Aracati (superior) Membro Galinhos (médio) e Membro Upanema (inferior). Esta subdi visão foi porém baseada principalmente em dados de perfuração na plataforma continental, restando ainda dúvidas quanto à pos sibilidade de se estender essa subdivisão à porção emersa da bạ cia.

Litologia: segundo ARAUJO et alii (1978) a sequência Açu se inicia, em geral, por clásticos grosseiros, representados por arenitos quartzosos grosseiros, mal selecionados, em grãos suban gulosos, por vezes conglomeráticos, ocasionalmente contendo feldspatos intemperizados (Membro inferior) aumentando gradati vamente a porcentagem de finos em direção ao topo. A porção su perior (Membro mëdio e superior) é em geral constituida por are nitos finos muito argilosos, siltitos argilosos, argilas verme Ihas (tambëm acinzentadas na área leste da bacia), com interca lações de margas e calcarenitos.

SOUZA (1982) define a Formação Açu, como SAMPAIO \& SCHALLER (1968) em duas seções: uma inferior mais espessa, avermelhada, composta por conglomerados e arenitos com delgadas intercala ções de folhelhos e siltitos, e uma superior, menos espessa constituida por arenitos finos, intercalados com folhelhos es verdeados. 
Comportamento estratigrăfico: a Formação Açu è aflorante numa faixa que circunda a bacia, em sua porção emersa entre as rochas do embasamento cristalino e os calcários da Formação Jan daira. E recoberta em pequenas áreas isoladas, pelos aluviões dos rios Jaguaribe, Apodi-Mossoró, Upanema-do Carmo, PiranhasAçu e Cabugi-Mulungu-Amargoso (MAPA 3). Assenta-se discordante mente sobre as rochas metamórficas e ígneas do embasamento cris talino nas porções marginais da Bacia, bem como sobre os sedi mentos da Formação Pendência, na sua porção central. Em direção ao mar esta unidade grada lateralmente para a Formação ponta do Mel e Formação Ubarana.

Na porção oeste da faixa de afloramento, a Formação Açu apresenta uma espessura média de cerca de $100 \mathrm{~m}$ e nas porções média e leste, uma espessura média igual ou inferior a $50 \mathrm{~m}$. As espessuras māximas são atingidas no centro da Bacia entre as localidades de Areia Branca e Porto do Mangue, onde são observa das espessuras da ordem de $800 \mathrm{~m}$. (IPT, 1982)

Idade: a Formação Açu abrange idades Albiano(?), Cenomania no e Turoniano (REGALI \& GONZAGA, 1982 "apud" SOUZA, 1982).

\subsubsection{Formação Jandaíra}

Nome, histórico: a Formação Jandaíra é constituída pela se quência carbonātica da porção emersa da Bacia potiguar, engloban do calcārios bioclästicos, calcārios gredosos, dolomitos, habi tualmente com fase terrígena pouco expressiva, tendo recebido, segundo CYPRIANO \& NUNES (1968) diversas denominações, a saber:

- Calcário Apodi (JENKIS, 1913; PASHAK, 1956 e COOK, 1956);

- Apodi Group (KREIDLER, 1949), que o divide em três unidades e apresenta a denominação de Calcărio Jandaira em seus mapas;

- Calcārio Jandaíra (KEGEL, 1957).

BEURLEN (1961, 1967) divide os calcārios em dois complexos: o inferior (turoniano) e o superior (campanianomaestrichtiano); ao inferior dá a denominação de Formação Sebastianōpolis e ao superior, de Formação Jandaíra.

Finalmente essa sequência carbonätica foi definida por SAMPAIO \& SCHALLER (1968), informalmente como Formação Jandaí 
ra e, formalmente, por CYPRIANO \& NUNES (1968).

Litologia: a Formação Jandaíra apresenta ampla variação lí tológica, tanto vertical como horizontal, tendo sido jä descri tos calcārios cinzas, calcārios cremes, margas, siltitos, folhe lhos, argilitos e dolomitos cremes.

Segundo CYPRIANO \& NUNES (1968) perfurações realizadas na porção ocidental da Bacia, revelam que na base da Formação Jan daíra predominam cazcärios cinza esbranquiçados, duros, densos, recristalizados, coquinóides, muitas vezes ooliticos, pisoliti cos, muito fossiliferos, de um modo geral nodulosos e argilosos. Intercaladamente ocorrem margas branco-amareladas finas, friáveis, localmente bastante fossiliferas e ainda calcarenitos e siltitos cinzas, duros e friáveis, estratificados, com grãos su bangulares a arredondados. Junto ao contato com a Formação Açu. ocorrem ainda camadas de fothetho verde a cinza escuro, calcife ro, carbonoso e irregularmente estratificado.

Na porção superior da Formação Jandaîra, porēm, predominam calcários de cor creme-cinza, microcristalinos, duros, a muito duros, maciços, acamamento médio, pouco fossilíferos, com inten sa recristalização e muitas vezes com geodos preenchidos por drusas de calcita.

Adotando a conceituação litológica proposta por ' KEGEL (1957) MENOR et alii (1980) definiram as rochas aflorantes em quatro grupos, a saber:

Calcäriosconchiferos: calcärios biodetriticos beges e compactos de textura média a grosseira, fratura irregular, incluindo frag mentos de conchas e foraminiferos perceptíveis a olho nu ou com o auxilio de Iupa;

Calcärios lajeados: calcārios esbranquiçados a bege claros, com pactos, de textura fina até mëdia, com fratura subconchoidal a irregular, macroscopicamente afossiliferos a pouco fossiliferos, exibindo frequentemente recristalização pontual e "bird-eyes" . Em afloramentos exibem comumente uma erosão alveolar ou em la piaz.

Calcários compactos: calcários cremes a cinzentos, muito compac tos, de textura fina a mēaia, fratura irregular, macroscopica 
mente afossiliferos no setor oriental da Bacia (geralmente fos siliferos no setor ocidental), caracterizando-se por uma recriś talização generalizada, difusa, e às vezes pela presença de ca vidades alveolares submilimétricas.

Calcários gredosos: calcários brancos a esbranquiçados, friá veis, macroscopicamente afossiliferos a pouco fossiliferos (pre sença de equinóides).

MENOR, "ibidem", através de parâmetros estatisticos de com ponentes químicos, conclui sobre a composição mineralógica des ses grupos litolögicos, conforme segue:

a) os calcários conchiferos são cãlcícos, podendo admitîr uma certa contaminação terrígena, porém pouco frequentemente do lomíticos;

b) os calcārios lajeados, podem admitir teores elevados de Mgo, porém raramente uma fração terrígena considerável;

c) os calcários gređosos, podem ser tanto cálcicos como magne sianos, comportando frequentemente uma fração terrígena não negligenciāvel; e

d) os calcários compactos apresentam dominância das rochas doio míticas, às vezes um pouco arenosas. Apresentam, porém, uma dominância de representantes cälcicos na zona ocidental da Bacia, geralmente fossiliferos.

A distribuição espacial das litologias aflorantes è apre sentada na FIGURA 8. A anālise dessa distribuição permitiu àque les autores diferenciar três zonas na bacia; a saber:

a) zona ocidental, onde dominam os calcários lajeados;

b) zona mediana, onde dominam os calcärios conchíferos; e

c) zona oriental, onde dominam os calcários compactos.

Algumas feições particulares porëm se destacam : desse com portamento geral, tais como:

- uma ärea transversal de calcārios conchiferos inserida na zo na ocidental onde predominam os calcários lajeados; 


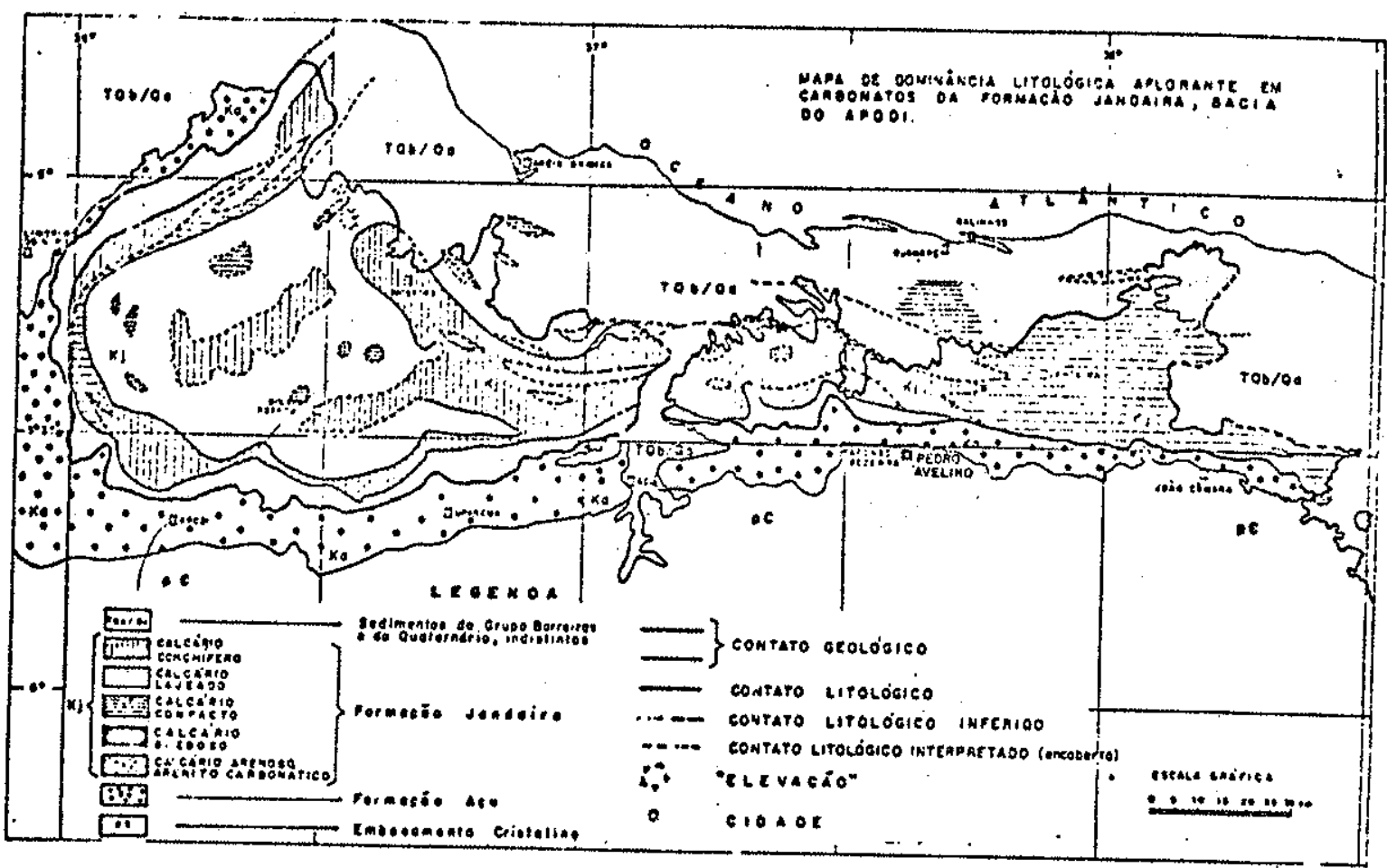

FIGURA 8 - Mapa de dominância litológica aflorante em carbonatos da Formação Jandaíra (MENOR, et alii, 1980).

- a incidência de horizontes de arenitos carbonāticos caracteri zando a zona mediana;

- a presença de calcários conchiferos na região de parazinho/ Pedra Grande, quebrando a hegemonia dos calcários compactos da zona oriental.

Segundo MENOR et alii "ibidem", a base da Formação Jandaira é constituída por calcários lajeados, superpostos por calcārios conchíferos, com intercalações de calcārios compactos, fenômeno que pode ser acompanhado até a zona oriental, onde, nas proximidades da cidade de Jandaira é constatada uma transi ção para o domínio quase exclusivo dos calcários compactos.

- mapa de variação de CaO e Mgo è apresentađo na FIGURA 9.

A distribuição desses constituintes permitiu tambēm àque les autores caracterizar repartições na bacia, tais como:

a) zona ocidental: domínio das rochas cálcicas;

b) zona mediana: aproximadamente ao longo de uma linha que une 


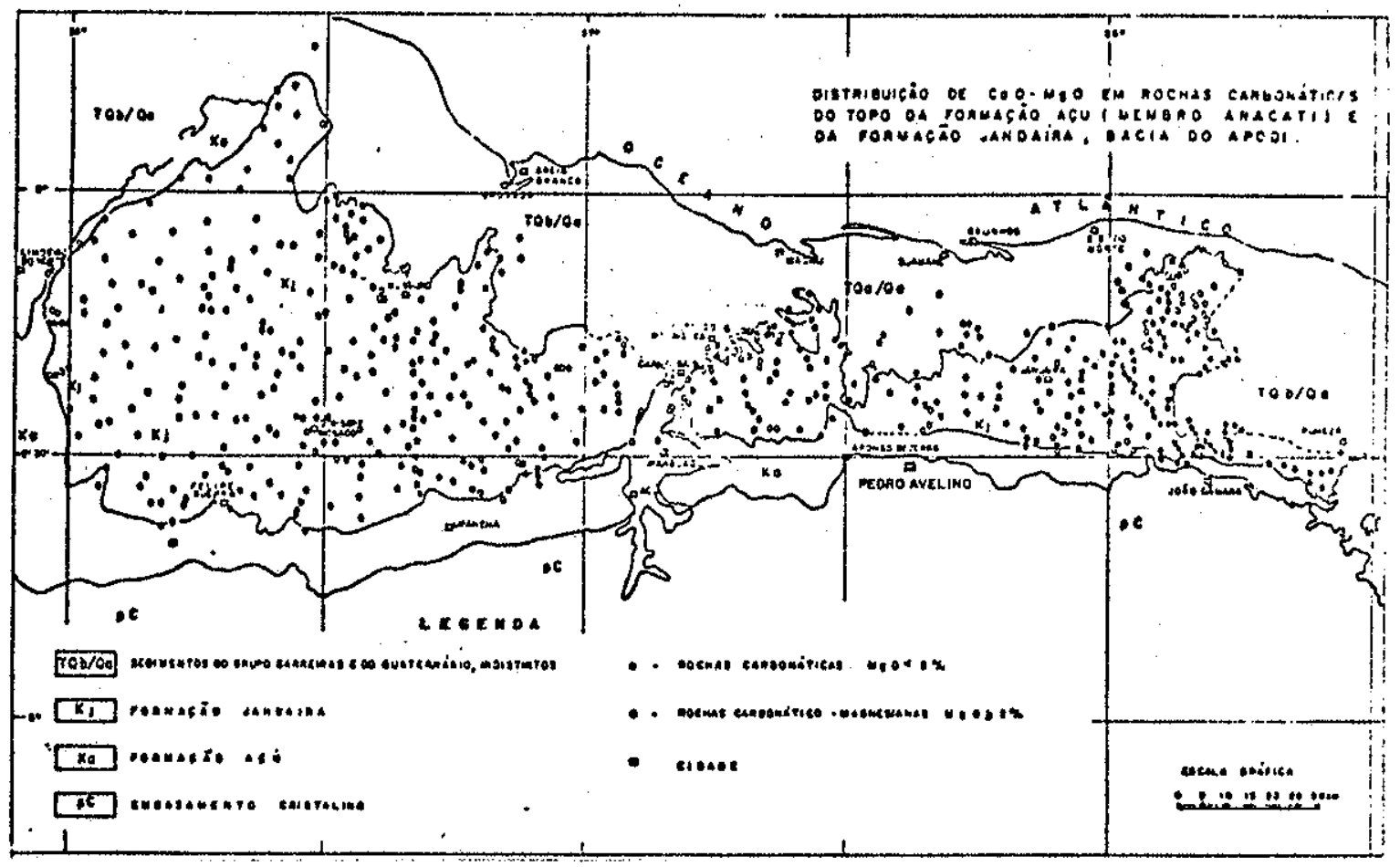

FIGURA 9 - Distribuição de CaO-Mgo nas rochas carbonāticas do topo da Formação Açu e da Formação Jandaíra (MENOR et alii, 1980).

Guamaré a Pedro Avelino situa-se uma faixa de brusca transi ção entre o domínio das rochas cälcicas e das rochas dolomí ticas;

c) zona oriental: domínio das rochas magnesianas. ções :

Fazem exceção a esse comportamento geral as seguintes fei

- as rochas dolomíticas que se intercalam no topo da Formacão Açu, dispostas, por isso, ao longo do contacto desta com a For mação Jandaíra;

- as faixas dolomíticas descontínuas que se situam na zona oci dental e mediana; e

- os calcārios conchíferos (encravamento cálcico) situado na re gião de Parazinho/Pedra Grande no domínio dolomitico caracte rístico da zona oriental da bacia. 
A fase terrígena, essencialmente quartzo-feldspätica, tem sua maior participação no topo da Formação Açu e na sequência basal da Formação Janđaỉra, cujas ocorrências estão vinculadas às menores distâncias do contacto entre estas duas formações. Uma incidência marcante de aportes terrigenos afeta a zona me diana da Bacia, chegando a constituir horizontes de calcärios arenosos e arenitos carbonáticos incluidos na sequência sedi mentar da Formação Janđaỉra. Na zona ocidental porēm esses aportes são limitados, enquanto na zona oriental há uma presença conspicua desses aportes, nas proximidades de Parazinho e Pe dra Grande.

Na FIGURA 10 são apresentadas as āreas correspondentes a litologias do pólo cálcico, que contêm um mínimo de $90 \%$ de cal cita. Como se pode notar, estas litologias ocupam preferencial mente as zonas ocidental e mediana da bacia.

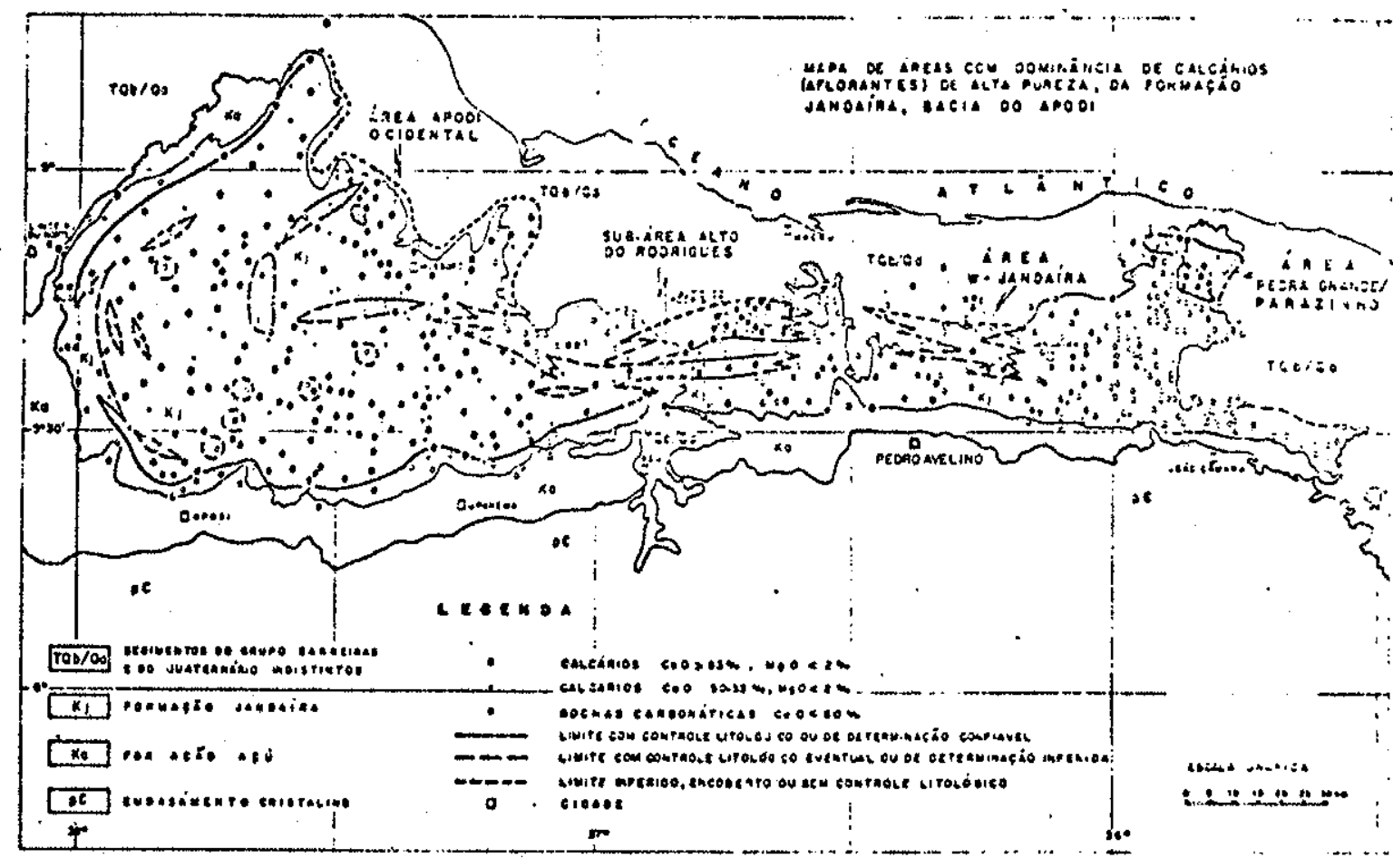

FIGURA 10 - Mapa com as āreas de dominância dos calcários aflo rantes de alta pureza (MENOR et alii, 1980).

Na FIGURA 11 são apresentadas as litologias do pólo magne siano, constituídas por dolomitos cálcicos contendo um minimo de 758 de dolomita e menos de $20 \%$ de fase terrigena (Residuo in solūvel: RI). Observa-se que essas litologias ocupam preferen cialmente a zona oriental da bacia.

De uma maneira geral, como se pode notar, as äreas corres pondentes às litologias do pólo cálcico e do pólo magnesiano se 
ajustam aos limites das dominâncias litológicas apresentadas na FIGURA 8.

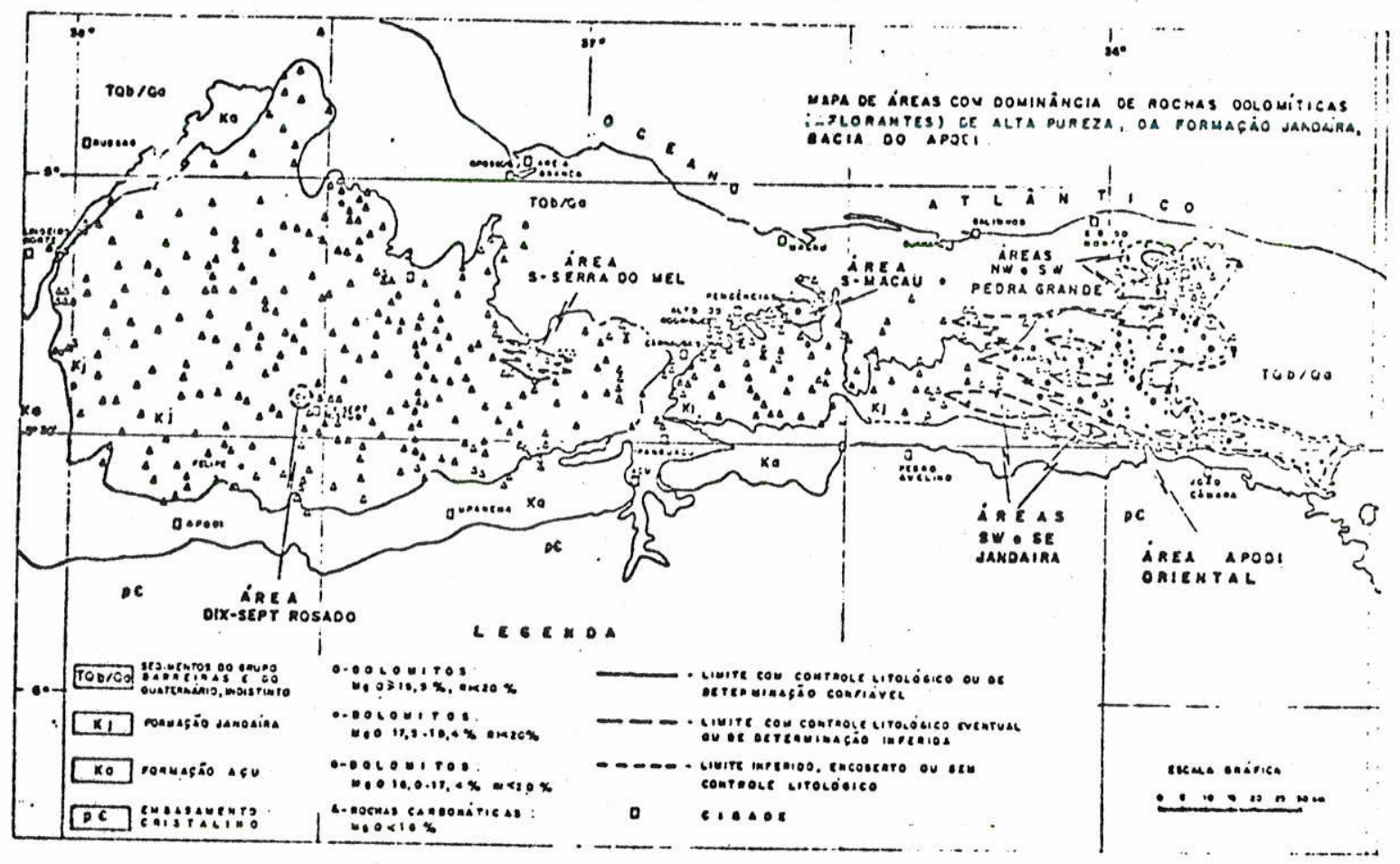

FIGURA 11 - Mapa com as āreas de dominância das rochas dolomíti cas aflorantes de alta pureza (MENOR et alii, 1980).

Ocorrências de gipsita, depósitos evaporíticos e rochas fos fatadas têm sido assinaladas em pontos distintos da bacia. A ocorrência de gipsita na sua porção sudoeste, nas proximidades da cidade de Governador Dix-Sept Rosado foi inicialmente consi derada por BEURLEN (1964) como incluída na parte média da Forma ção Jandaíra, que a relaciona com um hiato deposicional entre o que denominou de Formação Sebastianōpolis e Formação Jandaíra. SAMPAIO \& SCHALLER (1968) consideram que a mesma ocorrência se situa no limite superior da Formação Açu e CYPRIANO \& NUNES (1968) a consideram próxima do topo da Formação Jandaíra. MENOR et alii (1980) sugerem por sua vez, que todas as ocorrências de gipsita, evaporitos, rochas fosfäticas e argilitos, corresponde riam aos limites de distintos ciclos deposicionais da Formação Jandaíra.

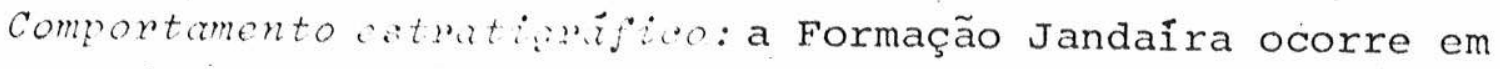
todo o dominio da Bacia Potiguar, se expondo na maior parte da ārea em uma ampla superfície erosional (chapadas), sendo reco 
berta nas proximidades da costa, de uma maneira continua, por uni dades terciārias (Grupo Barreiras) e quaternárias (aluviões, dụ nas e praias) item 5.3.9. "Cuestas" calcārias evidenciam o: seu limite a oeste e a sul, junto à Formação Açu.

Em superficie o contacto da Formação Jandaíra com a Forma ção Aqu è bastante evidente, onde aquela se assenta em contacto concordante sobre os sedimentos da Formação Açu, bem conspícuo pela linha de crista da escarpa de "cuesta". Em sub-superficie esse contacto se mostra tambēm bastante caracteristico nos per fis litológicos e elétricos. o contorno estrutural da base da Formação Jandaíra é apresentado no MAPA 4.

O contacto superior representa uma grande superficie ero sional achando-se exposta em sua maior parte.

Em sua porção. recoberta a Formação Jandaíra se encontra ora sob os sedimentos terciärios da Formação Tibau ou do Grupo Barrei ras, ora sob os derrames basālticos da Formação Macau ou ainda sob sedimentos aluvionares, praias e dunas.

A Formação Jandaira apresenta um padrão de espessamento bastante irregular na porção oeste, crescente de noroeste em di reção a Mossoró e de oeste, sudoeste e sul, em direção ao ria cho Bonsucesso (MAPA 5). A partir dai o maior eixo de deposi ção se direciona para a serra do Mel onde a espessura da Forma ção atinge o seu valor máximo com $580 \mathrm{~m}$ junto à linha de costa, entre as localidades de Areia Branca e Porto do Mangue. Nas por ções central e leste da Bacia o padrão de espessamento jä se torna mais regular e crescente em direção ao oceano.

Ambiente deposicional: a deposição da Formação Jandaíra se deu em ambiente de plataforma interna, sob condições de super-maré, acompanhada de subsidência gradual, em periodo de relat $\underline{i}$ va quietude tectônica (ARAOJo et alii, 1978).

Idade: SAMPAIO \& SCHALLER (1968) admitem que os sedimen tos da Formação Jandaira foram depositados no intervalo de. tem po compreendido entre os andares Turoniano e Santoniano. CYPRIA NO \& NUNES (1968), concordam com BEURIEN (1961) em idade Turonia na para o pacote inferior (Formação sebastianópolis). Por não haver indicios de fauna do Coniaciano, BEURLEN "ibidem" admitiu um hiato entre a unidade inferior (Formação sebastianōpolis) e 
a superior (Formação Jandaíra) para a qual determinou idade Sañ toniana-Maestrichtiana.

TIBANA \& TERRA (1981) "apud" SOUZA (1982) a consideram do Turoniano ao Maestrichtiano e SOUZA, "ibidem", a considera Turo niano a Campaniano inferior, em virtude do Maestrichtiano pex tencer a umà seqtência sismoestratigráfica superior em relação à Formação Jandaíra.

Descontinuidades: devido a interesses para esta monografia as descontinuidades mapeadas por CYPRIANO \& NUNES (1968) tais como falhas normais traçadas em aerofotos, falhas normais infe ridas, diaclases, fraturas e lineações retilineas identificadas na superfície aflorante da Formação Jandaĩra bem como em sua porção recoberta pelos sedimentos terciärios foram submetidas a tratamento estatístico. Deve-se ressaltar que a ārea de mapea mento das descontinuidades corresponde à porção da bacia desde - seu extremo oeste até o meridiano $36^{\circ} \mathrm{W}$, representando porém a maior parte do domínio da Formação Jandaỉra.

o processamento dos dados foi feito atravēs da aplicação do programa GEOVET(GAMA, 1982), cujos parâmetros estatísticos obtidos foram registrados sobre o mapa geológico (MAPA 3) deven do-se ressaltar porēm que nesse mapa estão representadas somen te as descontinuidades mais expressivas mapeadas por aqueles au tores. Dessa maneira foram elaborados os seguintes mapas:

- Ireqtência de direções das continuidades nas células em rela ção ao domínio, por intervalos de direções - histogramas circu lares ou rosāceos - (MAPA 6);

- direções médias das descontinuidades por célula (MAPA 7);

- relação entre o comprimento das descontinuidades e o compri mento total das descontinuidades no domínio, por intervalo de direçães - histogramas circulares ou rosäceos (MAPA 8);

- frequência de descontinuidades (no de desc. $/ \mathrm{km}^{2}$ ) - curvas de isofrequência - (MAPA 9); e

- densidade de descontinuidades $\left(\mathrm{km}\right.$ de desc. $\left./ \mathrm{km}^{2}\right)$ - curvas de isodensidade :- (MAPA 10).

Observando-se o mapa de freqtência de direções das descon 
tinuidades (MAPA 6) pode-se verificar que há notōrio aumento re lativo da frequência na porção ocidental da bacia, na chapada do Apodi, embora haja fraturamentos de grande expressão nas ou tras porções da mesma. Nota-se também que hã genericamente maior freqtência de descontinuidades no quadrante No. Dentro dessa tendência geral porēm se destacam três āreas que apresentam maior freqtência em outras direções. Assim temos o núcleo de cê lulas na porção central da Chapada do Apodi, onde as maiores fre quências de direção estão nos intervalos praticamente NS e duas áreas bastante distantes entre si, com direções mais frequentes no quadrante NE, parecendo seguir o mesmo padrão de direção das descontinuidades existentes no embasamento cristalino. A primei ra dessas āreas está situada entre uma linha que une a serra Dantas (quartzitica) a Ponta Grossa (no litoral) e o baixo vale do rio Mossoró; a segunda, localizada na porção oriental da bạ cia, para leste do baixo vale do rio Mulungu, e que provavelmen te se continue até o seu extremo leste.

o mapa de direções médias (MAPA 7) è parcialmente concor dante com essas evidências, porēm deixa transparecer que em aI gumas células, embora haja dominio de freqtência em um determi nado setor angular. (MAPA 6), a direção mëdia (composição veto rial) das descontinuidades porém recai sobre outro setor. Tal situação ocorre na borda do domínio dos calcārios na porção oci dental da bacia, desde sul de Dix-Sept Rosado até o limite su doeste da Chapada do Apodi. No restante do domínio praticamente ocorre coincidências de intervalos angulares de maior frequência e direçöes médias

No MAPA 8 estão representados os comprimentos relativos das descontinuidades em cada intervalo angular, comparativamente ao comprimento total no domínio, no mesmo intervalo. As rosäceas representativas nas cëlulas apresentam praticamente o mesmo com portamento das freqtências de direções (MAPA 6) sendo notōria a dominância de maiores comprimentos totais das descontinuidades na porção ocidental da bacia e na região das serras do carmo e do Mel. Nota-se ainda que os comprimentos são em geral crescen tes em direção à orla marítma.

No MAPA 9 estão traçadas as linhas de isovalores das fre quências das descontinuidades por cëlula, onde se destacam al guns núcleos de elevada frequência, tais como: região da serra de 
Mossoró, sudoeste de Maxixe, nordeste de Felipe Guerra, norte de Upanema , oste da Serra do Carmo, a leste da Serra do Mel,região entre os rios Açu e Mulungu e a sudoeste de Jandaíra. Nota-se tambēm aqui maio res valores na porção ocidental da bacia.

As curvas de isovalores de densidade das descontinuidades (MAPA 10) denotam praticamente os mesmos nücleos encontrados no mapa de freqtência, revelando assim que o padrão geral é portan to de aglomerados de descontinuidades.

\section{3 .7 Formação Macau}

Nóme e histórico: desde KEGEL (1957) existem citações de ocorrências de derrames basālticosna Bacia potiguar, definidas por MAYER (1974) "apud" SOUZA (1982) como Formação Macau.

Litologia: SIAL (1975) apresenta duas sequências magmātị cas pós-paleozóicas no nordeste brasileiro:

- a primeira, constituida predominantemente por diabásios tole ticos que ocorrem sob a forma de diques com orientação geral E-W cortando rochas do embasamento cristalino,para os quais tem sido determinadas idades compreendidas entre 125 a $130 \mathrm{mi}$ 1hões de anos (Cretáceo);

- a segunda, álcali-basāltica, e que constitui a Formação Macau,é representada por "plugs", pequenos derrames e mais raramente por diques, e ocorre na margem da bacia tambëm cortando ro chas cristalinas (exemplo: Pico do Cabugi, nas proximidades de Lajes) e no interior da Bacia, onde corta os sedimentos cretáceos desde leste do rio Açu até proximidades ida cidade de Jandaira. As ocorrências em superfície apresentam, nesse domínio, um padrão geral com orientação SE-NW. Datações reali zadas em olivina-basaltos revelam idades entre 18 e 42 milhóes de anos (Terciārio) para esta sequência (SIAL, 1975). Os seus derrames estão presentes nas formações Tibau, Guamarē e Ubara na, e de acordo com datações baseadas em microfósseis esta uni dades abrange as ëpocas Oligoceno e Mioceno (SOUZA, 1982). 


\subsubsection{Grupo Barreiras (Terciário)}

\subsubsection{Introdução}

- Grupo Barreiras corresponde a uma seculência de sedimen tos pouco ou não consolidados, de cores variegadas, variando desde argilas até conglomerados, com estratificação irregular e indistinta. Assenta-se ora sobre o embasamento cristalino, ora sobre as formações cretãceas, destacando-se na lapa por uma dis coraância de erosão bastante pronunciada.

Os sedimentos do Grupo Barreiras ocorrem continuamente na faixa litorânea desde o Estado do Rio de Janeiro até o Estado do Pará, entrando mesmo nas baixadas amazônicas. Nos estados de Pernambuco, Paraíba e Rio Grande do Norte essa faixa atinge até $50 \mathrm{~km}$ de largura, persistindo ainda, de maneira descontínua, em algumas āreas no interior.

MABESOONE et alii (1972) fizeram uma correlação entre as áreas estudadas em superficie, por MORAES (1924), KEGEL (1957), LINS \& ANDRADE (1960), BIGARELLA \& ANDRADE (1964) e SUDENE-ASMIC (1967) e em subsuperfície, por CAMPOS \& SILVA (1969), com novós dados obtidos no campo, pelo reexame da maior parte dos aflora mentos anteriores descritos e exame de novos afloramentos. A partir dos estudos de campo, estudos sedimentológicos de labo ratörio e da histōria geológica da região, esses autores apre sentaram uma subdivisão do Grupo Barreiras em três unidades: inferior, média e superior, cada uma delas com uma capa de in temperismo típica e que são apresentadas nos itens que se se guem.

\subsubsection{Unidade inferior (Formação Serra do Martins)}

Nesta formação estão incluídas a Sērie Serra do Martins de MORAES (1924), Formação infra-Barreiras de KEGEL (1957), Forma ção Mossorō de LINS \& ANDRADE (1960), e Formação Tibau, de CAM POS \& SILVA (1969), "apud" NABESOONE et alii (1972).

Tanto em superficie como em subsuperfície, a Formação ser ra do Martins é constituída por uma sequência arenosa até aren tica. Sua espessura pode atingir $30 \mathrm{~m}$. 
Nas suas ocorrências nas chapadas do interior do Estado do Rio Grande do Norte e da Paraiba, possui a seguinte litologia: na base, a sequência é arenosa, friāvel, caulinica, de colora ção branca, com algumas camadas mais escuras, geralmente de co res roxa e amarela; para cima, essas areias caulinicas cedem $1 \underline{u}$ gar aos arenitos, localmente silicificados, até quartzitos sedi mentares; na parte superior, hă sequência arenosa atē conglome rática, com cimento ferruginoso e bastante dura. Encerrando a sequência. surge uma capa lateritica de arenitos ferruginosos, seja em blocos soltos, seja em forma de crosta. Geralmente, es ta sequência superior ferruginosa estā ausente nas regiões cos teiras, talvez devido à erosão. Em resumo, esta unidade se apre senta com dois pacotes bastante distintos em cores: um infexior, branco e outro superior, avermelhado.

\subsubsection{Unidade mëdia (Formação Guararapes)}

Com esta denominação foram incluĩdas a Formação Guararapes e a Formação Riacho Morno de BIGARELLA \& ANDRADE (1964) e a For mação Barreiras, do Vale do Jaguaribe, da SUDENE-ASMIC (1967).

A unidade mëdia se compõe de sequência variegada, com. se dimentos arenosos até argilosos, em camadas horizontais ou em lentes, com pequenas discordâncias erosionais locais, marcadas por leitos de seixos. No campo esses depósitos se destacam pe las cores vivas e pela estratificação irregular, às vezes se transformando em laminação perturbada. Sua espessura pode atin gir $40 \mathrm{~m}$.

No topo desta unidade existe uma capa de intemperismo que destruiu a estratificação original pela infiltração de óxidos de ferro. Estes se apresentam em forma de manchas ou colunas verticais,às vezes cimentados até arenitos ferruginosos: é o de nominado Intemperismo Riacho Morno. Essa capa de intemperismo segue mais ou menos a superficie atual sendo porém truncada nos vales mais profundos.

A Formação Guararapes se encontra ao longo da costa, cons tituindo as "barreiras" dos rios, inclusive do baixo Jaguaribe e as falésias das praias, desde Recife (PE) até Aracati (CE). 
5.3:8.4 Unidade Superior (Formação Macaíba)

Com esta denominação foram incluidas por MABESOONE et alii (1972) a Formação Macaíba e Formação potengi de CAMPOS \& SILVA, (1969) e a Formação Faceira da SUDENE-ASMIC (1967).

E constituida de uma sequência essencialmente arenosa até argilosa, de coloração clara, com bastante caulim, tendo na ba se um horizonte de espessura variável de seixos de quartzo e de rochas cristalinas. A granulometria ë bastante irregular e a es tratificação muito indistinta. Raramente ocorrem concentrações de óxido de ferro, e quando existem, se apresentam em forma de pequenas manchas alaranjadas até avermelhadas. Sua espessura po de atingir $20 \mathrm{~m}$.

MABESOONE et alii "ibidem", consideram que a Formação Ma caíba está separada dá Formação Guararapes por uma evidente diś corâancia de erosão.

Capeando esta unidade há uma série de intemperismo pouco espessa de areias até siltes avermelhados, com concentrações de öxido de ferro na superficie, sem constituir contudo cros tas inteiras. Esse capeamento foi chamado de Intemperismo poien $g i$.

\subsubsection{Ambiente deposicional e idade do Grupo Barreiras}

Estudos da composição granulomētrica, do carāter morfoscó pico e morfomētrico dos grãos de areia e ainda de lâminas petro gräficas de amostras cimentadas permitiram a MABESOONE "apud" MABESOONE et alii (1972) estabelecer os seguintes ambien tes de deposição:

$$
\text { FORMAÇÃO AMBIENTE DEPOSICIONAL }
$$

Macaíba $\quad \ldots \ldots \ldots \ldots$ Fluvial

Guararapes.......... Combinação de corridas de lama e rios, indicando clima bastante rigoroso, semí -ärido.

Serra do Martins .... Fluvial, distante das fontes de sedimen tos; influência de processos litorâneos. 
Segundo MABESOONE et alii, "ibidem", a datação das diver sas formações estratigráficas afossiliferas do Grupo Barreiras é muito problemática.

Tanto BIGARELLA \& ANDRADE (1964) como MABESOONE (1966), da taram-na a partir de bases paleoclimáticas e portanto através de un critério bastante inseguro. Segundo esse critērio, tem-se:

$$
\text { FORMAÇÃO }
$$

\section{IDADE}

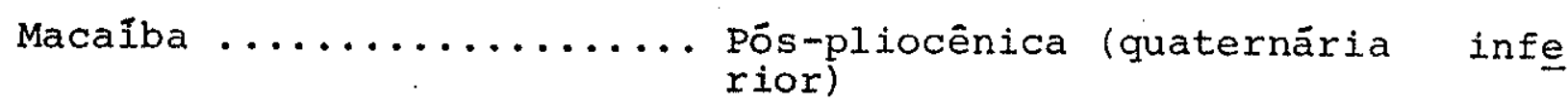

Intemperismo Riacho Mormo .. Pliocênica Superior

Guararapes ............ Miocênica superior a pliocênica

Serra do Martins ........ Oligocênica (?) (oụ mais antiga)

\subsubsection{Aluviōes, Praias e Dunas (Quaternārio)}

\subsubsection{Aluviões}

No dominio da Bacia Potiguar, os aluviões que merecem destaque são os relacionados aos rios Jaguaribe, Apodi-Mossoró e Piranhas-Açu. Secundariamente, os aluviões dos rios Upanema - do Carmo e Cabugi-Mulungu-Amargoso.

A litologia desses aluviões ë bastante variāvel mas de uma maneira geral são constituĩdos por clásticosocasionalmente gros seiros com matriz argilosa, por vezes rica em matëria orgânica.

No baixo curso dos principais rios, os aluviões ocorrem em forma de tabuleiros escalonados por desniveis de poucos metros e também na forma de planícies de inundação. Na borda desses ta buleiros, em contacto com os calcários da Formação Jandaíra, po dem ser encontradas cascalheiras contendo blocos de silex, de quartzo e de diversas rochas do embasamento cristalino jacente a montante desses grandes rios.

Fato notório é o desenvolvimento de intensas planícies alu vionares sobre os afloramentos da Formação Açu nas áreas onde - rio Apodi e o rio Piranhas passam de sobre os sedimentos da Formação Açu para os calcārios da Formação Jandaira, criando a montante dessas penetrações, extensa ärea aluvionar devida à barreira litológica-geomorfológica das "cuestas" calcārias. 
Na planície aluvial do rio Apodi, próxima à cidade do mesmo nome, com base em dados de perfurações e de sondagens geofi sicas MANOEL FILHO (1971), estimou espessuras de atē $40 \mathrm{~m}$ para esses aluviões.

A planicie aluvial do rio Açu, localizada entre as cidades de Açu e Alto do Rodrigues, apresenta comprimento de cerca de $36 \mathrm{~km}$ e largura varianđo de 2,5 até $15 \mathrm{~km}$. O DNOCs (1976), ana lisando os perfis de diversas sondagens executadas na ärea, conclui que osir sedimentos perfurados equiva leriam aos aluviões e sedimentos de Formação Açu, que foram sub divididos em"aluvião superior" e "aluvião inferior". O IPT (1982) reinterpretando os dados disponiveis, sugere que os sedimentos que foram denominados "aluvião inferior" sejam,pelo menos em parte, correspondentes a uma variação faciológica da Formação Jandaira e ao topo da Formação Açu, considerando que os alu viões do rio Açu, nessa região, equivalem apenas ao "aluvião sú perior", definido naquele estudo e cujas espessuras máximas vâ riam de 20 a 50 metros.

\subsubsection{Praias e dunas}

A costa norte da Bacia potiguar apresenta uma faixa de até cerca de $10 \mathrm{~km}$ de largura que se estreita por vezes até $2 \mathrm{~km}$ e se interrompe na foz dos grandes rios, na qual ocorrem sedimen tos de dunas e de praias, intimamente relacionados.

As dunas, que nessa região atingem a cota máxima de $20 \mathrm{~m}$, são de pelo menos duas gerações. As mais antigas (pleistocêni cas?) encontradas mais para o interior, recobertas por vegeta ção pouco densa, formam uma sequência de cordões paralelos à li nha de costa; as mais recentes e atuais, móveis, modeladas pe lo vento nordeste, originam relevo caracteristico de cristas em semicirculo.

Deve-se notar ainda a presença de dunas sobre superficies de grande altitude, como são as encontradas no topo da serra do Mel, a uma altitude de mais de $150 \mathrm{~m}$.

Os sedimentos dunares são essencialmente constituídos por areias finas a médias, quartzosas, de coloração esbranquiçada nas dunas atuais e avermelhada nas dunas antigas. 
Os sedimentos de praias são representados por areias de granulação fina a grossa, quartzosas, micāceas com fragmentos de conchas, por vezes contendo argila, regularmente seleciona. dos e em geral de coloração amarelada ou acinzentada. 


\subsection{Introdução}

As crescentes demandas de ägua fazem com que no mundo in teiro atualmente se invistam capital em quantidades considerá veis em estudos hidrogeolögicos e em construção de obras de cap tação. Apesar disso porēm, no panorama mundial a utilização râ cional dos recursos hidricos subterrâneos è uma tecnologia pou co desenvolvida, tanto no que diz respeito às técnicas de levan tamentos exploratórios de aquíferos como em técnicas de capta ção dos seus recursos.

Entende-se por exploração de ãguas subterrâneas, o conjun to de atividades que permitem a localização e o recohhecimento de aquiferos a partir dos quais se pode obter ãgua em quantida de e qualidade adequadas aos diferentes fins. Não existe porém uma fronteira definida entre os trabalhos de exploração (pros pecção e avaliação) das reservas aquiferas e os de explotação (lavra) do recurso. A ênfase da primeira etapa estaria mais vol tada aos aspectos de reconhecimento e a da segunda, mais aos as pectos técnicos de captação e a aspectos organizacionais. o ca ráter multidisciplinar de ambos os niveis de atividades para o aproveitamento dos recursos hídricos subterrâneos conduz por tanto à cooperação de técnicos das mais diversas áreas das ciên cias para o equacionamento dos problemas relacionados ao supri mento de àgua.

No que se refere ao aquifero Jandaira, as pesquisas a ni vel exploratório nas áreas de conhecimento específico básico, tais como a Geologia, Geofísica, Hidrometeorologia e Hidrogeo química, embora na maioria das vezes não tenham tido suas ativi dades programadas com o objetivo de reconhecimento e avaliação hidrogeolögica, muito têm contribuido para o aprofundamento do conhecimento desse aquifero.

Resultados parciais das investigações no campo da Hidrome teorologia foram apresentados no item 4; os resultados das in vestigações Hidrogeoquímicas ora realizadas serão apresentadas no item 8. São apresentadas a seguir, algumas considerações das investigações na ārea de Geologia e Geofísica. 


\subsection{Investigações Geolōgicas}

São básicas para os estudos hidrogeológicos, uma vez res ponsãveis pela correta caracterização da geometria dos aquife ros, da sua composição mineralógica e portanto com consequên cias na composição quimica das águas e ainda pelo fornecimento de dados que permitem a estimativa das suas reservas e o conhe cimento dos seus mecanismos de fluxo.

Os estudos exploratórios da Formação Jandaíra a nível re gional geralmente têm sido o produto secundário de estudos ex ploratórios com o objetivo de pesquisas de hidrocarbonetos (pe tróleo) programadas pela PETROBRÁs na Bacia potiguar, tanto atra vés dos mapeamentas geológicos como através das sondagens mecâ nicas e geofísicas (métodos sísmicos e elétricos) por ela execú tadas.

o reconhecimento litológico e estrutural sobre a Formação Jandaira têm advindo ainda secundariamente de mapeamentos desti nados à prospecção mineral, tais como os mapeamentos executados pela CPRM (1978), MENOR et alii (1980) e MME (1981).

A maioria das sondagens mecânicas de reconhecimento que forneceram informações sobre a estratigrafia desde o topo até à base da Formação Jandaira refere-se às sondagens a cargo da PETROBRÁs, tendo sido executadas por vārias entidades estatais, entre as quais o DNPM, a CPRM, e a própria PETROBRÁs. Os poços delas resultantes construỉdos até 1979, tendo sido inventaria dos pelo IPT tiveram tambēm seus parâmetros utilizados nesta monografia.

Poços tubulares para abastecimento em ägua, conquanto te nham caräter restrito e parcial em termos de penetração na For mação Jandaíra, têm se constituỉdo em uma excelente fonte de in formações e dados sobre o comportamento litológico, estrutural. e hidrāulico da Formação Jandaíra. A sua distribuição quase ho mogênea na área de dominio do aquífero Jandaira facilita os es tudos de reconhecimento desse aquifero a nivel regional.

\subsection{Investigações Geofisicas}

\section{3 .1 Sondagens Geofísicas}

As sondagens geofisicas na Bacia potiguar têm se processa 
do tanto atravēs de campanhas que objetivam a prospecção de pe tróleo como as que objetivam a prospeç̧ão de água subterrânea, sendo as primeiras, até agora executadas pela PETROBRAs e as ültimas, pela SUDENE, pela secretaria de Indüstria e comércio do Estado do Rio Grande do Norte-SIC/RN e Companhia de äguas e esgotos do Rio Grande do Norte - CAERN.

A seleção do método de prospecção geofísica a ser emprega do em uma determinada ārea bem como a qualidade da "resposta " que esse método poderá fornecer estão condicionadas principal mente ao contraste, em termos de propriedades físicas, existen tes entre as formações geológicas que compõem a estratigrafia dessa ārea.

são apresentadas a seguir algumas considerações concernen tes a prospecções geofísicas feitas atravēs de sondagens elétri cas verticais (SEVs) uma vez que os métodos sismicos têm sido utilizados apenas pela PETROBRĂ, e cujos dados usualmente não se encontram disponíveis.

- QUADRO 7 apresenta os dados gerais sobre as medições geoe lêtricas de longo alcance efetuadas na Bacia Potiguar pela SUDENE, CAERN e secretaria de Indüstria e Comércio do Rio Grande do Nor te-SIC-RN, em convênio com o Instituto de Pesquisas Tecnológi cas do Estado de São Paulo-IPT.

Para facilidade de referência as SEVs foram agrupadas em dois conjuntos:

a) SEVs executadas nas porções ocidental e central da Ba cia Potiguar, abrangendo os quatro primeiros projetos referidos no QUADRO 7;

b) SEVs executadas no extremo oriente da Bacia. Correspon dentes às sondagens executadas pelo IPT

As condições gerais de execução e os resultados das intex pretações dessas sondagens são apresentados nos itens que se se guem.

a) Sondagens elétricas verticais na porsão ocidental e central da Bacia Potiguar

Para as mediçōes geolētricas foi utilizado como arranjo, o quadripolo linear simétrico AMNB, de Schlumberger.

A anälise das medições geoelëtricas permitiu constatar uma 


\begin{tabular}{|c|c|c|c|c|}
\hline & Projetos & $\begin{array}{c}\text { SEVs } \\
\text { Na área de } \\
\text { interesse }\end{array}$ & $\begin{array}{l}\text { Epoca das } \\
\text { Medições }\end{array}$ & $\begin{array}{c}\mathrm{AB} \\
\text { (metros) }\end{array}$ \\
\hline 1). & $\begin{array}{l}\text { Bacia Escola de } \\
\text { Hidrogeologia } \\
\text { (SUDENE) (123 SEVs) }\end{array}$ & $\begin{array}{r}42 \mathrm{BP} \\
45 \mathrm{BP}-49 \mathrm{BP} \\
90 \mathrm{BP}-92 \mathrm{BP} \\
95 \mathrm{BP}-99 \mathrm{BP} \\
101 \mathrm{BP}-103 \mathrm{BP} \\
105 \mathrm{BP}-114 \mathrm{BP} \\
122 \mathrm{BP}-123 \mathrm{BP}\end{array}$ & $\begin{array}{c}06 / 66 \text { a } \\
08 / 67 \\
\text { (não contínuo) }\end{array}$ & $\begin{array}{l}1000 \mathrm{a} \\
6000\end{array}$ \\
\hline 2) & $\begin{array}{l}\text { Abastecimento } \\
\text { d'ägua de Macau } \\
\text { e Pendências } \\
\text { (Estudo reali- } \\
\text { zado pela CAERN } \\
\text { (21 SEVs) }\end{array}$ & $1 C-2 I C$ & $\begin{array}{c}10 / 09 \text { a } \\
05 / 10 / 72 \\
\text { (contínuo) }\end{array}$ & $\begin{array}{r}4000 a \\
14000\end{array}$ \\
\hline 3) & $\begin{array}{l}\text { Estudo hidrogeo } \\
\text { lógico da Planí } \\
\text { cie Aluvial do } \\
\text { Apodi/RN (SUDENE) } \\
\text { (70 SEVS) }\end{array}$ & $47 \mathrm{AA}$ & $02 / 74$ & 1000 \\
\hline 4) & $\begin{array}{l}\text { Projeto Apodi } \\
\text { Estudo Estrutural } \\
\text { da parte W da } \\
\text { Bacia Potiguar }\end{array}$ & $1 A-52 A$ & $\begin{array}{c}27 / 01 \text { a } \\
06 / 09 / 74 \\
\text { (não continuo) }\end{array}$ & $\begin{array}{r}2000 \mathrm{a} \\
14000\end{array}$ \\
\hline 5) & $\begin{array}{l}\text { Estudo hidrogeo } \\
\text { lógico detalha- } \\
\text { do do Estado do } \\
\text { Rio Grande do } \\
\text { Norte SIC-RN/ } \\
\text { IPT-SP ( } 24 \text { SEVs) }\end{array}$ & $001-011$ & $\begin{array}{l}06 / 04 \text { a } \\
01 / 05 / 81\end{array}$ & $\begin{array}{r}800 \mathrm{a} \\
1000\end{array}$ \\
\hline
\end{tabular}

QUADRO 7 - Campanha de medições geoelêtricas de longo alcance na Bacia Potiguar (FEITOSA, 1978, modificado). 
boa diferenciação elétrica das principais unidades litolögicas. 0 QUADRO 8 a seguir. sumariza as características da sequência geoe létrica genērica e a sua corresponđência com a sequência geoló gico-estratigráfica da Bacia Potiguar.

\begin{tabular}{|c|c|c|}
\hline $\begin{array}{l}\text { Horizonte } \\
\text { Geoelétrico }\end{array}$ & $\begin{array}{l}\text { Resistividade Elétrica } \\
\text { verdadeira (ohm.m) }\end{array}$ & Sequēncia Estratigräfica \\
\hline 1 & $40-80$ & \\
\hline 2 & $10-30$ & Formação Janđaíra \\
\hline 3 & $50-150$ & \\
\hline 4 & $3-8$ & $\begin{array}{l}\text { Conjunto Formação Açu/For } \\
\text { mação Gangorra }\end{array}$ \\
\hline 5 & $\infty$ & Embasamento Cristalino \\
\hline
\end{tabular}

QUADRO 8 - Características geoelētricas das principais formações geológicás da Bacia potiguar (FEITOSA, 1978)

A FIGURA 12 a seguir mostra três exemplos de sondagens elé tricas verticais onde é possivel distinguir bem a sequência geoe létrica apresentađa no QUADRO 8.

Segundo FEITOSA, "ibidem" a metodologia de interpretação das medidas geoelētricas foi fundamentada em sondagens elētri tricas de aferição, (parametrização) cujo referencial foram 16 poços tubulares profundos que atingiram o embasamento cristali no, tendo sido utilizados diversos artifícios de interpretação além do conhecimento anterior sobre os sedimentos da Bacia. Foi utilizada tambëm a metodologia clássica de interpretação conhe cida na literatura como método dos pontos auxiliares segundo a variante de EBERT (1945) "apud" FEITOSA (1978).

o controle de que dispunha com os poços-referência, entre os quais muitos possuíam perfilagem elétrica, permitiu àquele autor, prever um erro mäximo da ordem de $20 \%$ na estimativa das medidas de profundidade do embasamento e das espessuras do con junto Açu/Gangorra, admitindo porëm a possibilidade de erros maiores, em função de condições locais das SEVs, tais como zonas estruturalmente baixas (fossas e depressões) que poderiam con ter ai ăguas salgadas onde os erros tenderiam a provocar a super estimação daquelas medidas. 


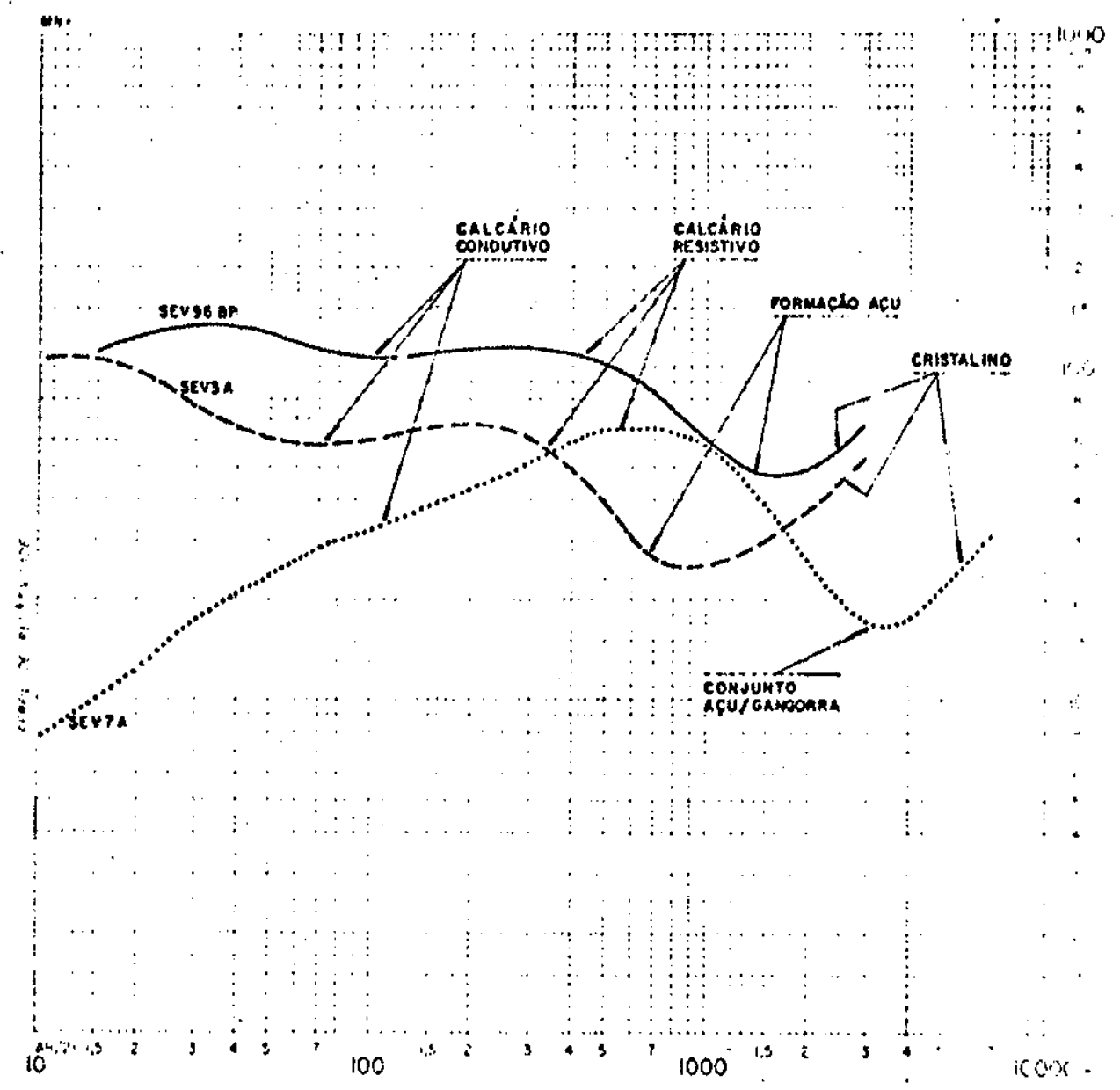

FIGURA 12 - Exemplos de sondagens elētricas na porção ocidental da Bacia Potiguar (FEITOSA, 1978)

A localização bem como alguns parâmetros de interesse obti dos na interpretação das medições geoelêtricas efetuadas são apresentados na TABELA 1 (ANEXO B).

Quanto às espessuras māximas da Formação Jandaíra, a linha de interpretação adotada conduziu a uma tendência em superesti mação sistemática das mesmas, da ordem de 10 a $40 \%$.

A metodologia utilizada não permitiu tambēm ãquele autor, detectar eventuais reduções de espessura dessa formação devidas a movimentos tectônicos positivos seguidos de exosão, ou seja, como o limite superior atual dos calcärios constitui uma ampla superfície de exosão, è possível que existam locais associados a altos estruturais, mesmo relativos, onde a espessura tenha si do consideravelmente reduzida por erosão.

Em termos de resultados obtidos no âmbito de toda a Bacia 
Potiguar, segundo FEITOSA (1978), pode-se dizer que a interpre tação das medições geoelētricas das sondagens BP permitiu o es boço geral da Bacia Potiguar, e a das medições geoelétricas efe tuadas para o abastecimento de Macau e Pendências permitiu o ma peamento do "graben" de Pendências.

No mapa de isópacas da Formação Janđaíra (MAPA 5) são apre sentadas as SEVs que se encontram dentro da área de estudo, al gumas das quais utilizadas para o seu traçado.

b) Sondagens elétricas verticais no extremo leste da Bacia Poti guar

As sondagens elétricas verticais executadas nessa área são as relativas ao "Estudo Hidrogeológico regional detalhado do ES tado do Rio Grande do Norte", a cargo do IPT (1982). Nesta ärea os objetivos das SEVs estavam voltados para a determinação da profundidade do embasamento cristalino e para a possibilidade de caracterização de zonas condutoras em subsuperfície, que pu dessem indicar zonas mais promissoras para a captação de ãgua subterrànea.

As curvas de resistividades aparentes resultantes das sondagens elétricas foram interpretadas utilizando-se também o mé todo de pontos auxiliares, e os modelos matemäticos obtidos fo ram comparados com os resultados de campanha anteriormente rea lizada pelo IPT em áreas de geologia semelhante. Para a inter pretação final o modelo definitivo foi selecionado com base na anälise conjunta das curvas de resistividades aparentes com a utilização do método das aproximações sucessivas atravēs de seu programa de cálculos por computador. Foram considerados ainda os dados litológico-estratigráficos obtidos a partir de alguns poços tubulares utilizados para captação de ăgua, existentes na área.

Na FIGURA 13 estão representadas as curvas de resistivida des aparentis e as colunas geoelétricas obtidas a partir da in terpretação dos diagramas elëtricos, relativos à SEV-005 exe cutada nas proximidades dos poços no 901-18 e 19 e à SEV-016, executada nas proximidades dos poços $1055-29$ e 30 .

A metodologia adotada permitiu estabelecer os seguintes es tratos geoelētricos na área das sondagens: 

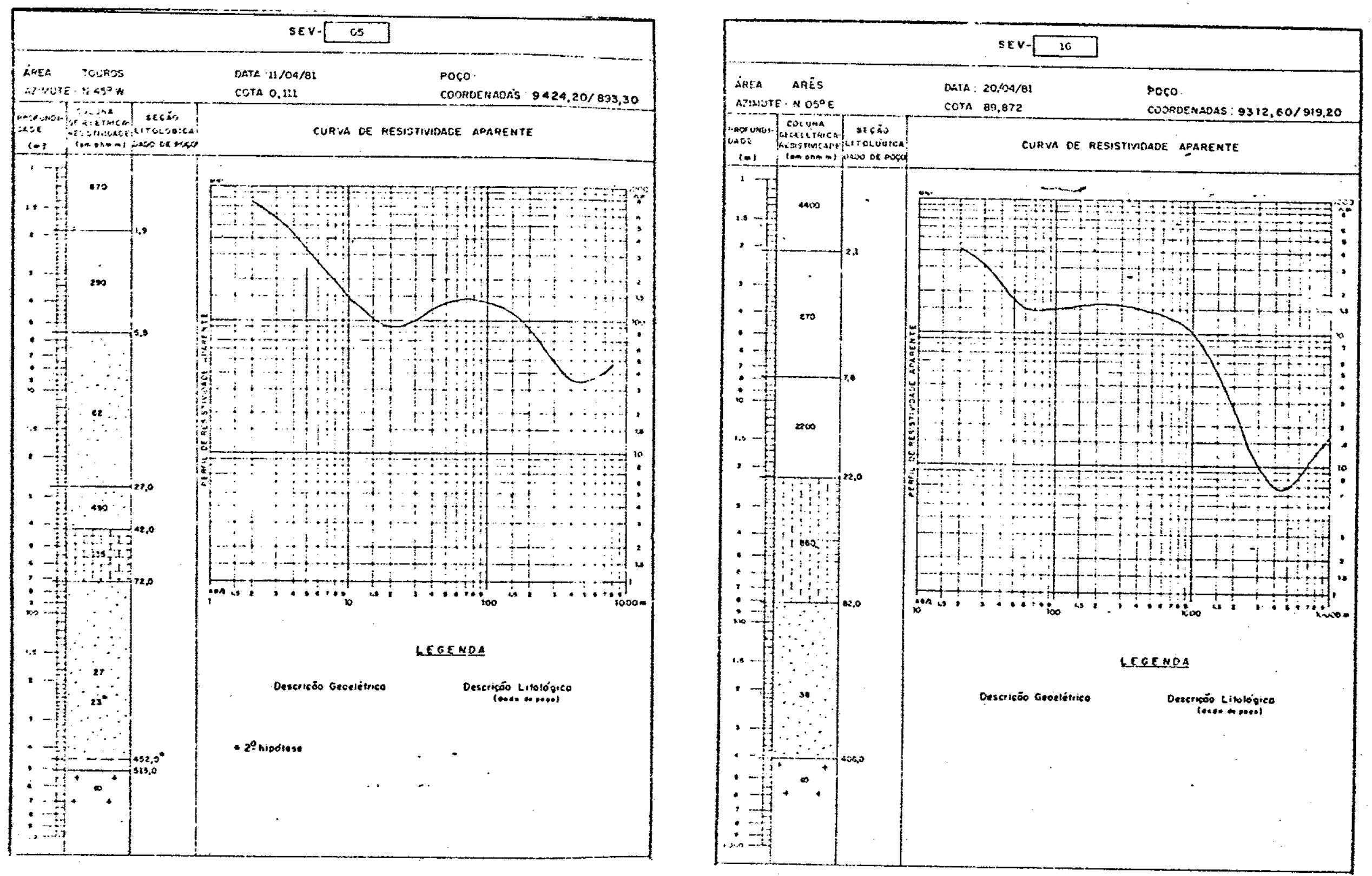

FIGURA 13 - Exemplos de sondagens elétricas verticais na porção oriental da Bacia Potiguar 
- sedimentos superficiais;

- sedimentos cenozóicos e/ou mesozöicos, e

- rocha sã (embasamento cristalino)

Os resultados gerais, em termos de resistividade são sinte tizados no QUADRO 9 a seguir.

\begin{tabular}{|c|c|c|c|}
\hline $\begin{array}{l}\text { Horizonte } \\
\text { Geoelétrico }\end{array}$ & $\begin{array}{l}\text { Resistividade elétrica } \\
\text { verdadeira (ohm.m) }\end{array}$ & $\begin{array}{c}\text { Sequência } \\
\text { estratigráfica }\end{array}$ & $\begin{array}{l}\text { Espessura } \\
(\mathrm{m})\end{array}$ \\
\hline 1 & 2 a 10000 & $\begin{array}{c}\text { Sedimentos } \\
\text { superficiais } \\
\text { Sedimentos } \\
\text { Cenozóicos e/ou } \\
\text { Mesozóicos }\end{array}$ & 2 a 56 \\
\hline 2 & $\begin{array}{l}105 \text { a } 930 \\
\text { (valores pouco frequen } \\
\text { tes: } 1200 \text { e } 2800 \text { ) }\end{array}$ & $\begin{array}{l}\text { a) nivel resis- } \\
\text { tente }\end{array}$ & 8 a 127 \\
\hline & 11 a 91 & $\begin{array}{l}\text { b) nivel condu- } \\
\text { tor }\end{array}$ & 9 a 441 \\
\hline 3 & $\infty$ & $\begin{array}{l}\text { Rocha sã (emba- } \\
\text { samento crista- } \\
\text { lino) }\end{array}$ & \\
\hline
\end{tabular}

nUADRO 9 - Características geoelëtricas da sequência estratigrä fica do extremo oriente na Bacia Potiguar (IPT, 198I)

A ausência de sondagens mecânicas com descrição detalhada dos termos litológicos, aliada à pequena profundidade dós pou cos poços existentes na ärea impediu uma classificação geológi ca mais precisa dos estratos geoelëtricos, quer seja ao nível dos sedimentos superficiais, quer seja também dos sedimentos ce nozóicos e/ou mesozóicos. Além desse fato, os denominados "sedi mentos superficiais" quando secos possuem resistividades que vä riam em uma ampla faixa em função da sua posição topogrä́fica. Esse estrato geoelëtrico poderia estar englobando uma variada sé rie de estratos geolögicos distintos ou seja, coluviões, elū viōes, solo de alteração, dunas, etc. Notou-se que os valores mais altos de resistividade nos sedimentos superficiais exam correspondentes às areias quartzosas das dunas que ocorrem logo após a linha de praia. 
o estrato "sedimentos cenozöicos e/ou mesozóicos" foi gene ricamente assim designado apenas em função da correlação entre a resistividade e o suposto modelo estratigráfico da ärea cô nhecido até então. Os níveis resistentes deste estrato em geral apresentam resistividades consideradas extremamente altas para sedimentos saturados e possivelmente estejam refletindo varia ções litológicas.

Os niveis elëtricos 115 ohm.m (SEV-005) e 860 ohm.m (SEV016) foram definidos como calcários, com base nos valores de re sistividade e principalmente pela correlação com dados litológi cos de poços construídos nas proximidades (poço 901-18 e poços 1055-29 e 30, respectivamente); jä os niveis de 1200 ohm.m (SEV009) e 2800 ohm.m (SEV-017), foram definidos tambëm como rochas calcárias, porém em função apenas dos valores de resistividades obtidos, uma vez que estão distantes de poços-referência, não se descartando, portanto a hipótese de serem correspondentes a paco tes de sedimentos arenosos com grande variação litolōgica.

De uma maneira geral os níveis condutores na coluna geoe lëtrica se localizam entre os niveis resistentes e a rocha sã (embasamento cristalino), tendo sido interpretados como corres pondentes a sedimentos saturados com água doce, possivelmente sedimentos calciferos apresentando uma pequena variação granulo mëtrica. Porēm, quando esses niveis estão localizados diretameñ te sobre o embasamento cxistalino (SEV-005, cuja espessura de sedimentos atingiu até $411 \mathrm{~m}$ ), deve-se considerar o fato de que à medida que se aumenta a profundidade de investigação, peque nas variações nas relações entre espessuras e resistividades (principalmente quando se tem uma faixa de variações relativa mente pequena de resistividades), podem provocar a integração de uma ou mais camadas litológicas em um único estrato geoelé trico - efeito de supressão de camadas. Assim sendo, para esses niveis condutores, imediatamente superiores ao embasamento não se descarta a possibilidade de ocorrência de variações litológi cas não detectadas pelas sondagens geofísicas.

o valor da resistividade (infinito) para o embasamento cristalino indica o alto contraste, em termos de resistividade, existente entre este estrato e os sedimentos que se sobrepõem a ele, isto $\vec{e}$, os sedimentos, por apresentarem valores de re- 
sistividade extremamente baixos, fazem com que o valor de resis tividade do embasamento cristalino tenda para o infinito.

Ainda, como pode ser observado na SEV-005, no que diz res peito à profundidade do embasamento cristalino, a interpretação admite uma segunda hipótese, ou seja, um segundo modelo geoelé trico para o local estudado, devendo-se tal fato ao chamado efei to de equivalência em que muitas vezes, mesmo com a existência de um forte contraste de resistividade entre as camadas, a in terpretação dos dados geofísicos pode apresentar duas ou mais soluções, isto é, os mesmos dados geofísicos podem admitir dois ou mais modelos geoelētricos de interpretação refletindo assim diferentes modelos geológicos para uma única situação geolōgi ca real.

As prospecções geofísicas de longo alcance, conquanto auxi liem na identificação dos estratos geológicos, podem apresentar resultados quantitativos portadores de erros, em áreas carentes de sondagens mecânicas de aferição, em que pese a utilização das mais poderosas técnicas de interpretação das medições geoelétricas. O traçado das isópacas do aquífero Jandaíra (MAPA 5) apresenta alguns locais onde na ocasião da execução das sonda gens elëtricas não havia poços tubulares e as espessuras se re velaram divergentes com as encontradas em perfurações executa das posteriormente naquelas äreas, como por exemplo a SEV no 52.

\subsubsection{Perfilagens Geofisicas}

Prospecções Geofísicas em furos de sondagem no domínio da Formação Jandaíra têm sido freqtentemente utilizadas pela $\mathrm{PE}$ TROBRAS com o objetivo de identificar os limites dos estratos geolögicos atravessados pelos furos. São comuns as diagrafias obtidas atravēs da perfilagem tērmica, perfilagem elētrica (po larização espontãnea, métodos resistivos, etc), perfilagens ra dioisotópicas (gama natural, gama-gama e neutrônica) e perfila gem sônica. Nessas perfilagens as propriedades físicas dos cal cārios permitem facilmente a sua identificação; constituem-se dessa maneira em excelentes técnicas para o estabelecimento do topo e da base da Formação Jandaíra.

SANTOS et alii, (1981) efetuaram perfilagens térmicas em poços tubulares com o objetivo de utilizar as tëcnicas geotërmi 
cas na interação do regime geotermal com o regime hidrológico subterrêneo no Estado do Rio Grande do Norte. Tais tëcnicas pex mitiram a identificação de níveis de circulação de ăgua e, no caso do aquífero Barreiras, a definição de zonas de recarga e dos intervalos convenientes à instalação dos filtros no inte rior dos furos para poços produtores de ägua da região de Natal.

A FIGURA 14 ilustra a identificação de anomalias tërmicas positivas no aquífero Jandaira, revelando a existência de movi mentos de ascensão da ăgua no interior do furo.

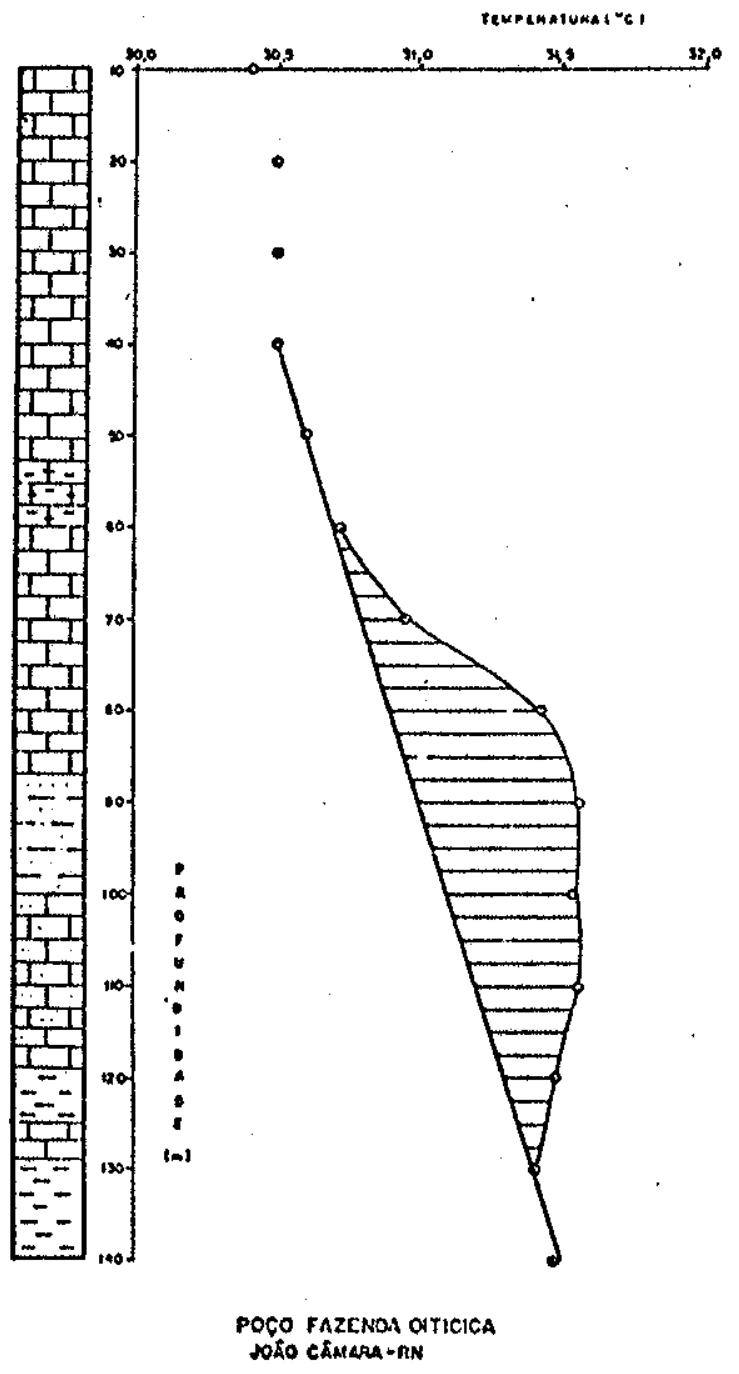

FIGURA 14 - Exemplo de perfilagem térmica em poços do aquífero Jandaira (SANTOS et alii, 1983).

Esses autores, utilizando os dados de gradientes geotërmi cos obtidos a partir dessas perfilagens e ainda de dados calcu lados a partir de medidas de fundo de poço (BHT) feitas pela PE TROBRÁs, elaboraram o mapa de gradientes geotérmicos e o mapa 
de tendência dos gradientes geotêrmicos da Bacia potiguar, que permitiram entre outras conclusões, reafirmar que o sentido do fluxo de ăguas subterrâneas se faz genericamente em direção ao mar.

\section{3 .3 Isótopos ambientais}

Técnicas mais modernas de exploração como as isotópicas, tambēm têm sido aplicadas em estudos visando à um melhor conheci mentio dos recursos hidricos da Bacia Potiguar. Neste campo tam bëm os conhecimentos sobre o aquífero Jandaíra advêm, primeirá mente de estudos regionais no nordeste e posteriormente de estu dos mais restritos, no âmbito da Bacia Potiguar geralmente pe lo interesse no aquífero Açu.

Entre as diversas aplicações das tēcnicas isotōpicas ūteis na exploração de aquíferos destaca-se a determinação dos isóto pos ambientais: Deutērio, Oxigênio-18 e Carbono-14 das suas äguas, üteis na elucidação de processos de recarga e, de uma ma neira geral, dos diversos aspectos do funcionamento hidräulico dos sistemas aquíferos.

A bibliografia têcnica da Bacia Potiguar conta com alguns estudos de isótopos ambientais em ăguas subterrâneas. os quais, devido principalmente ao pequeno nümero de determinações dispo niveis, ainda não trazem resultados conclusivos sobre os diver sos aspectos investigados.

o início das investigações hidrogeológicas utilizando prä ticas isotöpicas no nordeste do Brasil foi marcado com os estū dos realizados por uma missão de tëcnicos de Israel tendo sido estabelecido um programa de colaboração, sob a coordenação da Comissão Nacional de Energia Nuclear-CNEN, através de seu Depar tamento de Pesquisas Cientificas e Tecnológicas-DPCT, reunindo a SUDENE (PE), o Centro de Energia Nuclear na Agricultura - CENA (SP) e o Instituto de Pesquisas Radioativas-IPR (MG), visando à realização de estudos de viabilidade de utilização e de con tribuição das técnicas de emprego dos isótopos naturais na bus ca de soluções de problemas hídricos tipicos daquela região.

Em 1968, GAT et alii "apud" LEAL et alii (1974) apresenta ram os primeixos resultados dos levantamentos bāsicos executá dos atravēs daquele programa, em relatōrio (inédito) enviado à CNEN e à SUDENE. 
Em 1969, MELO et ali.i "apud" SALATI et alii (1976) apresen taram os primeiros dados sobre composição isotópica de āguas sub terrâneas daquela região (também inêdito), referentes aos estụ dos realizados pela mesma missão tëcnica.

Posteriormente, durante o Decênio Hidrológico Internacio nal foram obtidos, para a "International Atomic Energy Agency" IAEA, dados sobre a composição isotópica de águas pluviais de algumas localidades do Brasil.

Com base nesses estudos, SALATI et alii (1970) "apud" SALATI et alii (1976) apresentaram dados de concentração isotópica de O 18 em águas subterrâneas do nordeste brasileiro, ressaltando o emprego das técnicas de isótopos ambientais como forma de auxi liar na solução de alguns problemas hídricos daquela região.

LEAL et alii (1974) apresentaram os resultados das anāli ses de Tritio, oxigênio-18 e Deutério em amostras de āgua cole tadas pela suDENE no que concerne a ăguas pluviais, superfí ciais e subterrâneas, de locais representativos da região nor destina.

SALATI et alii (1976), com o objetivo precípuo de correla cionar a taxa de evaporaçãocoma salinidade das āguas subterrâa neas, analisaram as concentrações de $D$ e $O^{18}$ em ăguas de aquífe ros do nordeste, concluindo que as variações encontradas indi cam que tanto $O D$ como $O^{18}$ poderiam ser utilizados, em alguns casos, como traçadores de águas subterrâneas. Apresentam ainda composições isotōpicas de águas pluviais com o objetivo de ob ter informações sobre o mecanismo de recarga de aquíferos daque la região e correlacionar a taxa de evaporação com a salinida de das ãguas subterrâneas.

Dados isotópicos sobre Caxbono 14, somente começa ram a sex publicados em 1974, (SALATI et alii, 1974), para āguas subtexrâneas do aquífero Açu e äguas do aquífero cristalino nas circunvizinhanças da Bacia Potiguar.

Estudos restritosà Bacia Potiguar porëm somente foram rea lizados por MERCADO et alii (1976), objetivando avaliar o ba lanço hídrico das äguas subterrâneas na bacia atravēs da utili zação conjunta de dados hidrolögicos, hidroquímicos e isotópi cos.

Mais recentemente foram feitos, atravēs de um Programa de 
Cooperacão Técnica entre SIC/RN - IPT - IPEN - CENA (IPT, 1982)

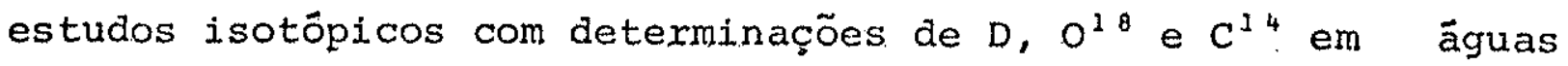
subterrâneas, tambêm com o objetivo de melhor conhecimento hi drogeológico da Bacia Potiguar e do aquifero Barreiras na re gião leste do Estado do. Rio Grande do Norte. Os resultados des sas determinações foram apresentadas em cinco relatórios tëcní cos (inéditos) do Instituto de Pesquisas Energēticas-IPEN (1981). Os dados levantados a partir dos documentos citados e que foram utilizados nesta monografia constam das TABELAS 2 e 3 (ANEXO B).

A anälise de algumas relações entre isótopos são apresenta das nos itens que se seguem:

A) Relagão entre Deutërio e oxigênio-18

a) Aguas pruviais

A composição isotópica das águas de precipitação depende de muitos fatores, porēm tendo em vista que o regime de precipi tação em uma determinada região é determinado por uma série de fatores que conduzem, até certo ponto, a uma periodicidade, é lí cito supor que dentro das oscilações estatísticas peculiares aos fenômenos meteorológicos, a āgua de precipitação de cada região possua uma concentração isotōpica mëdia característica de $D$ : e $0^{18}$.

A FIGURA 15 representa graficamente a correlação de $\delta D$ e $\delta 0^{18}$ em águas de chuva no nordeste brasileiro.

Para as águas meteóricas do nordeste, os valores de $\delta D$ e $\delta n^{18}$ se encontram bem distribuídos ao Iongo de uma linha equa cionada por SALATI et alii (1976) nos seguintes contextos:

- Aguas meteóricas de todo o nordeste:

$\delta D=9,7+7,6 \delta 0^{18}$ (coef. correl. de 91\%).

Essa equação de regressão foi obtida em uma anālise, em conjunto, das precipitações em diversas cidades do nordeste, às vezes localizadas nos mais distintos contextos climáticos. Como pode ser visto na FIGURA 15 existe uma grande dispersão dos pon tos representativos das amostras. Segundo LEAI et alii (1974), aparentemente essa variação estä associada às chuvas pouco in 


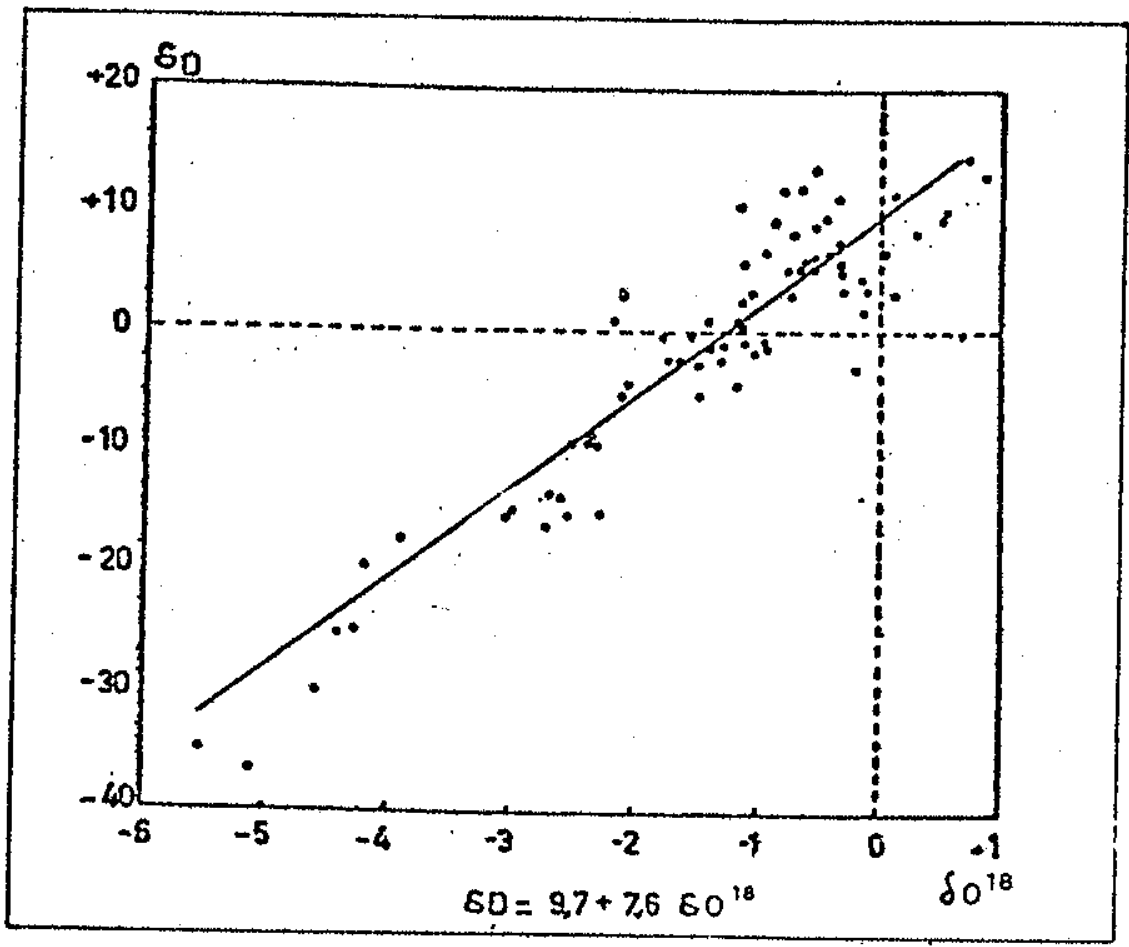

FIgURA 15 - Relação entre $\delta D$ e $\delta 0^{18}$ em äguas metéóricas do nor deste brasileiro (SALATI et alii, 1976)

tensas que permitem uma evaporação apreciāvel da ägua durante a sua queda e tambēm uma troca isotoppica entre a āgua de chuva e o vapor d'ägua da atmosfera. Ainda segundo esse autor, outras causas podem levar a essa dispersão, tais como chuvas de repre cipitação local ou de nuvens provenientes de äguas que tenham sofrido evaporação intensa e mesmo dificuldades na coleta de amostras que, no caso de chuvas pouco intensas, haveria possi bilidade de evaporação parcial da amostra.

Para as chuvas mais intensas esses efeitos parecem atenuados sendo bem menor a dispersão e, como essas chuvas são respon säveis pela parte mais significativa da recarga dos aquíferos, se constituem as mais importantes para os estudos hidrogeológi $\cos$.

- Aguas meteóricas apenas das regiões sedimentares.

Para estas águas que reúnem portanto, amostras mais próxí mas do litoral, SALATI et alii, "ibidem", apresentam a seguinte relação.

$$
\delta D=10+7,7 \cdot \delta 0^{18} \text { (coef. de correlação de 968). }
$$


Eșsas equações são semelhantes, podendo-se agrupar as äguas meteōricas dessa região em um só conjunto; porêm segundo aqueles autores, é provāvel que uma amostragem sistemática leve a uma variação entre a representação das chuvas litorâneas onde geralmente a precipitação é da ordem de $1700 \mathrm{~mm} / \mathrm{a}$, e a região do interior, onde a precipitação pode ser menor do que $400 \mathrm{~mm} / \mathrm{a}$ e que apresentam maior variabilidade de concentrações.

Determinando a correlação entre as concentrações de $D$ e $\mathrm{O}^{18}$ de um grande número de amostras, CRAIG (1961) "apud" SALATI et alii (1976) obteve a seguinte relação para as ăguas meteöri cas:

$$
\delta D=10+8,0 \delta 0^{18}
$$

Ainda, segundo DANSGAARD (1964). "apud" SALATT et alii (1976) os coeficientes linear e angular dessa equação variam com as condições de clima da região.

Pode-se notar então que as equações encontradas para as ăguas pluviais do nordeste estão bastante próximas da equação de CRAIG.

Se nenhum fator provocar modificações na composição isotó pica da água pluvial durante o processo de infiltração no solo, a composição isotópica da ägua subterrânea deverá ser a mesma da água de precipitação que a originou e que, nestas condições, deveria apresentar uma composição isotópica correspondente à mé dia ponderada das concentrações isotópicas da precipitação, em função dos volumes precipitados. Diversos fatores porém podem determinar modificações na composição isotópica das āguas sub terrâneas, entre os quais a evaporação se destaca como o mais importante, e que está presente desde o instante da precipita ção e durante a infiltração, até que o deslocamento se dê a profundidades nas quais o seu efeito seja desprezivel.

Durante os processos de evaporação subsequentes às precipi. tações haverá um enriquecimento diferencial entre $D$ e $0^{18}, \quad 0$ que pode ser verificado pelo coeficiente angular das equações representativas das amostras de corpos de ăgua submetidos ‘ à evaporação que deverão portanto apresentar valores menores do que da equação de $\operatorname{CRAIG}(\approx 8,0)$. 


\section{b) Aguas superficiais}

Segundo LEAL et alii (1974), as äguas superficiais, do nor deste, tanto as de rios após o periodo de cheias, como as de ré servatórios artificiais (açudes), se apresentam muito enriqueci das em $D$ e $0^{18}$, devido à evaporação intensa naquela região.

A FIGURA 16 a seguir representa a correlação de alguns da dos de $\delta D e 0^{18}$ de rios do nordeste brasileiro, contidos na TABELA $2 \mathrm{~b}$ (ANEXO B).

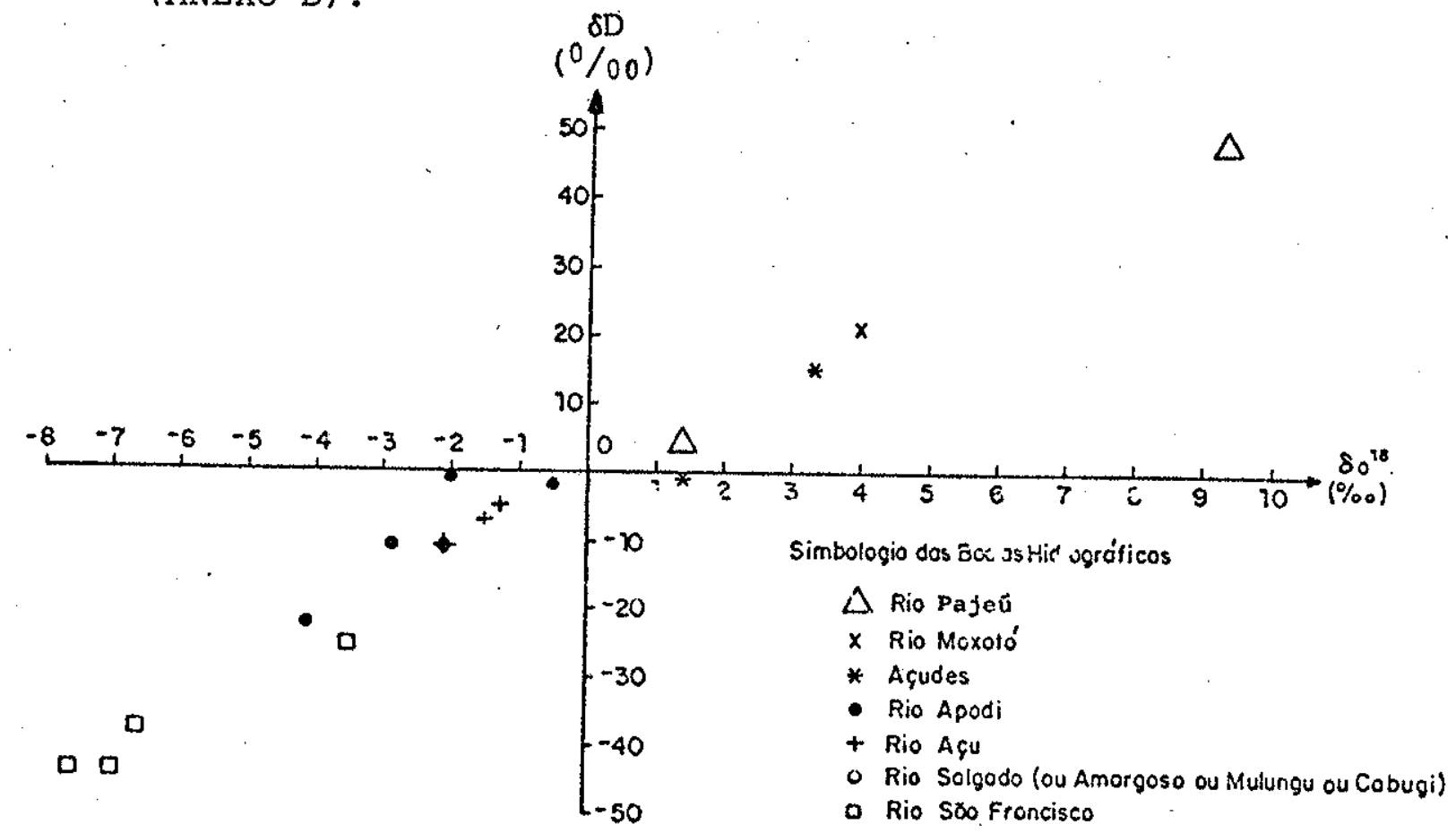
FIGURA 16 - Relação entre $\delta D$ e $\delta 0^{18}$ em äguas fluviais do Nordes
te.

SANTIAGO (1972) "apud" LEAL et alii (1974) através de estú do sistemático em um açude do Estado do Ceará demonstrou que a relação entre $\delta \mathrm{D}$ e $\delta O^{18}$ para as súas águas submetidas à evapora ção é a seguinte:

$\delta D=0,4+4,9 \quad \delta O^{28}$

c) Aguas de aquiferos da Bacia Potiguar

A FIGURA 17 apresenta graficamente a correlação das concen trações de $\delta D$ e $\delta O^{18}$ nas äguas subterrâneas dos aquíferos Bar reiras, Jandaira e Açu e tambēm nas ăguas de chuvas na Bacia Po tiguar ou em āreas litorâneas pröximas à mesma (TABELAS 2a e 3a, $b$ e $c$, ANEXO B).

As ăguas de chuva na ărea litorânea parecem ser relativa mente mais ricas em isōtopos estäveis, comparativamente às āguas 

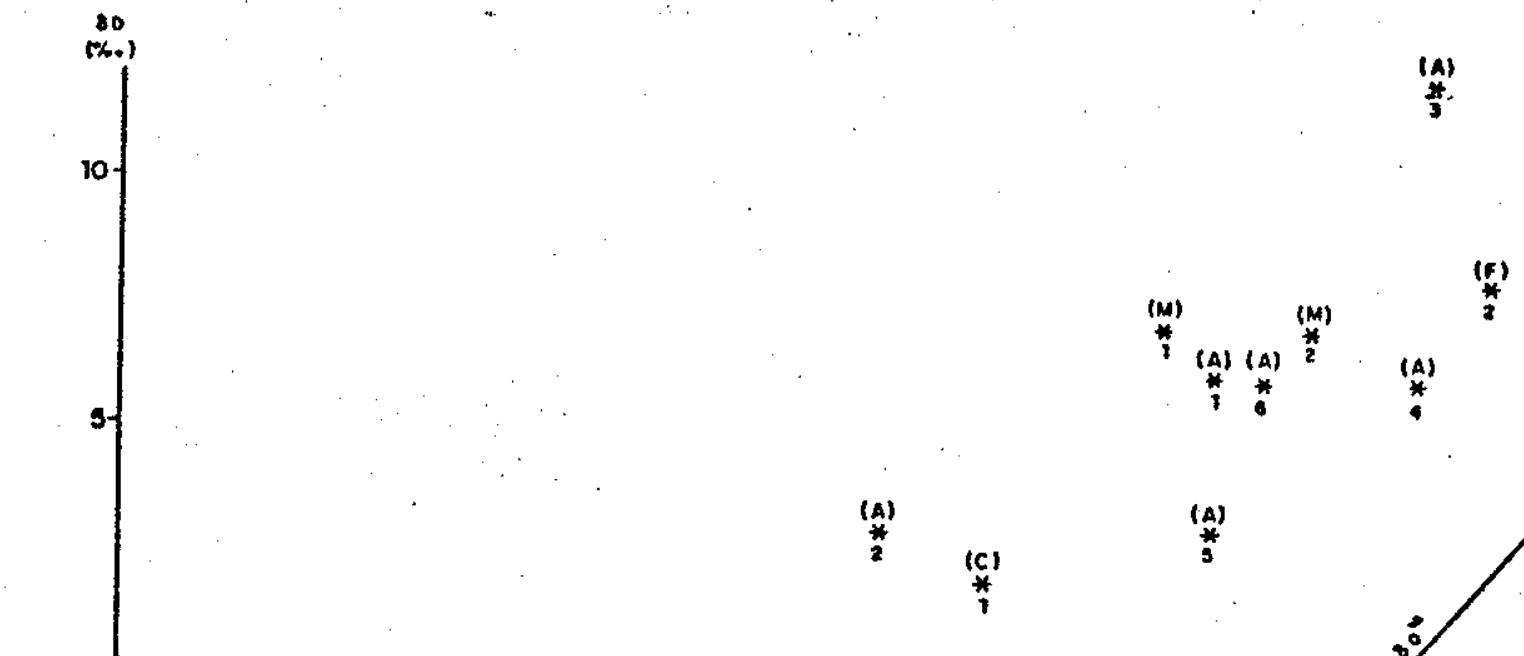

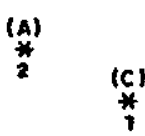
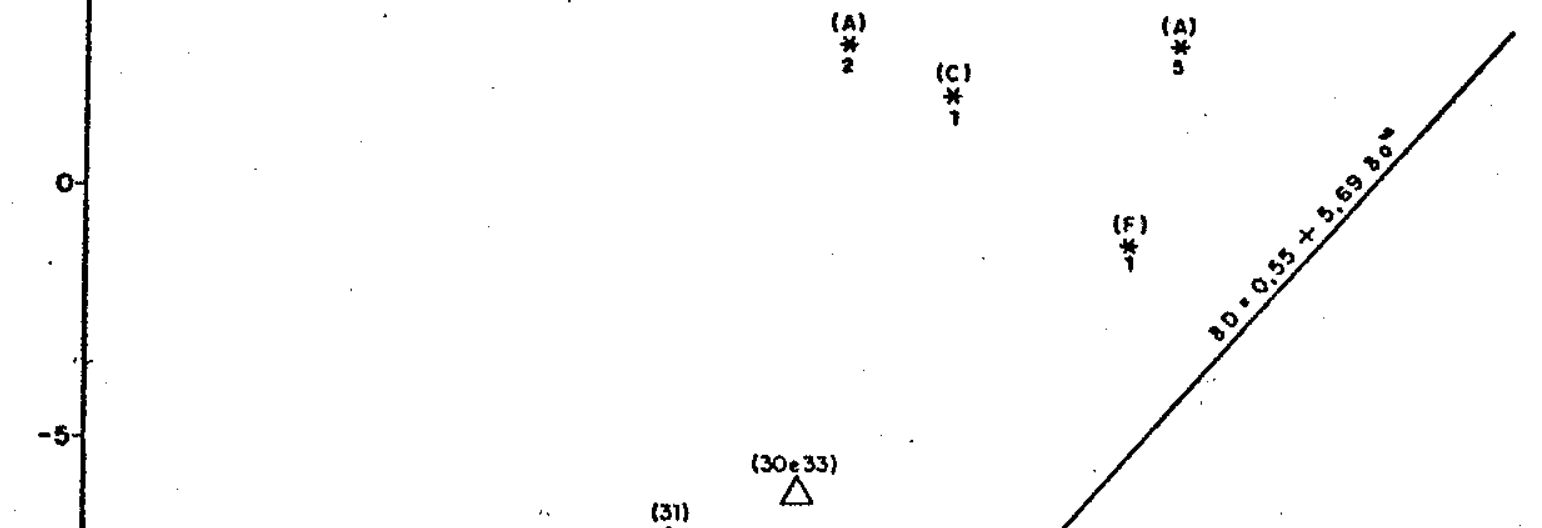

$\Delta$
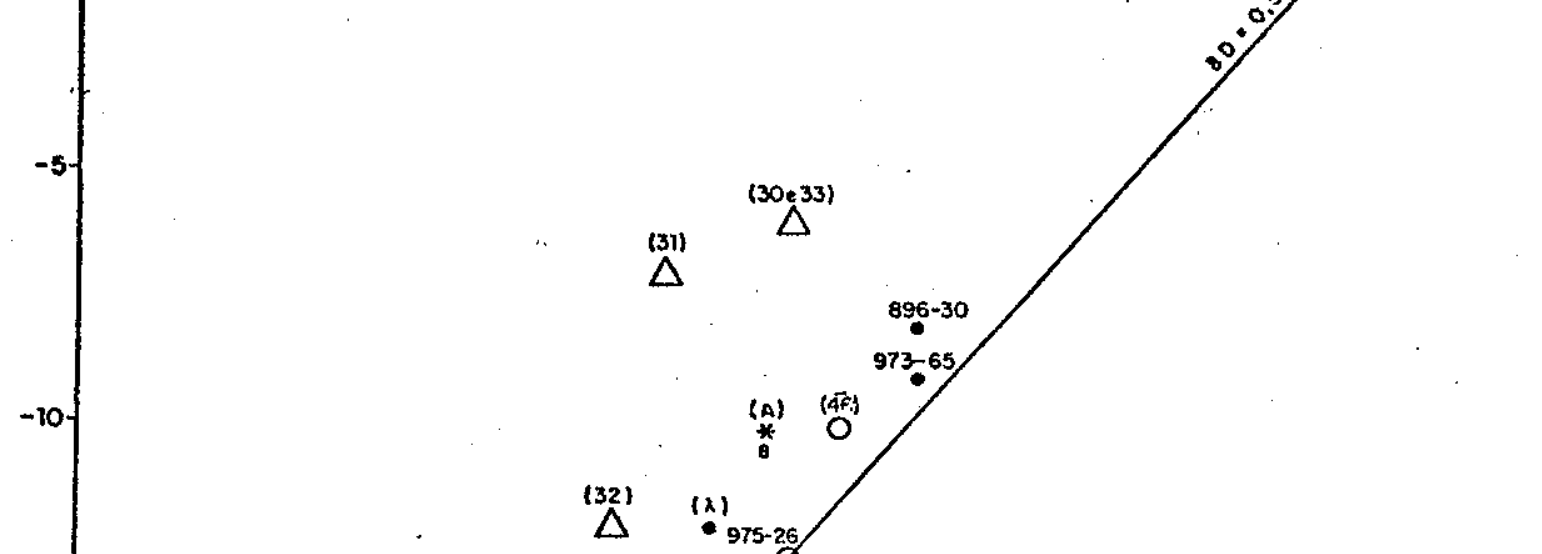

\section{(1)}

(x)
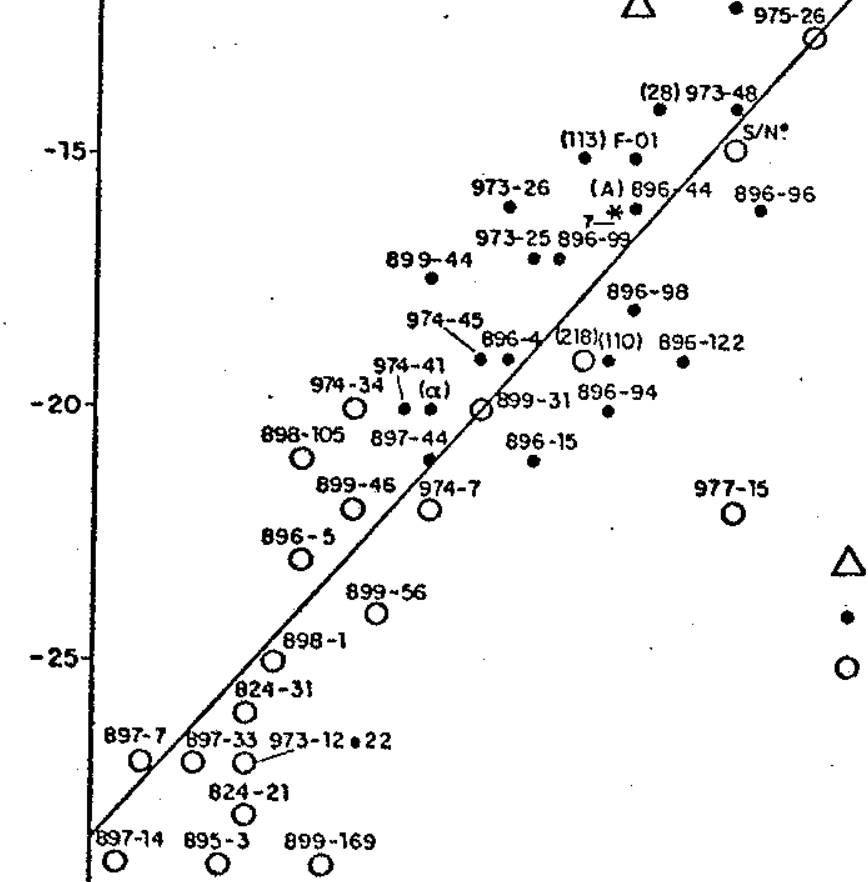

$\mathrm{O}^{87-14} \mathrm{O}^{895-3}$

895-3 (IPT)

(31) SALATH (1974) OU MERCADO (1976)

(40̈) LEAL (197\%)

* Áquos Meleóricạs do Bocio Potiguar e Circunvizinhanços

$M$ - Macou, $F=$ Fortolezo, A. Açu - (C)Cearo-Mirm

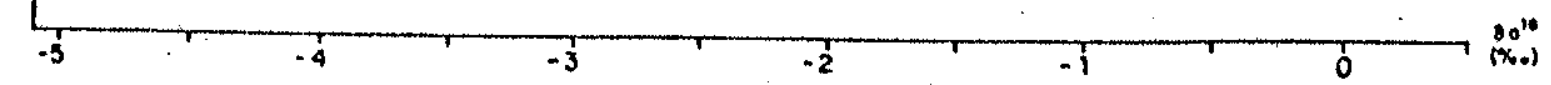

FIGURA 17 - Relação entre $\delta \mathrm{D}$ e $\delta 0^{13} \mathrm{em}$ āguas subterrâneas dos aquífe ros Jandaira e Açu. 
subterrâneas dos aquíferos Jandaira e Açu. Esse fato, segundo MERCADO et alii (1976). leva a supor que as chuvas do litoral são distintas das chuvas das áreas de recarga deșes aquíferos no que diz respeito à sua composição isotópica, cujas causas pro váveis seriam as diferenças existentes entre as características das chuvas no que diz respeito à intensidade e distribuição es pacial e temporal.

Embora na FIGURA 17 estejam plotados os pontos relativos ao aquífero Barreiras, este não foi considerado nos cälcu los de regressão por estar representado por amostras coletadas em uma faixa litorânea bastante abrangente desse aquífero e sem amostragem dentro da área da Bacia Potiguar. Assim, a equação re presentativa da relação entre $\delta D$ e $\delta 0^{18}$, para as ãguas subterrâ neas dos aquíferos Jandaíra e Açu pode ser expressa:

$$
\delta D=0,55+5,6 \delta 0^{18}
$$

Como pode ser observado na FIGURA 17, existe um zoneamento nịtido das águas dos diferentes aquíferos havendo um afastamen to gradativo em relação às āguas meteöricas, onde as ăguas do aquifero Barreiras apresentam as maiores concentrações de $\mathrm{D}$ e $0^{18}$, seguindo-se as do aquífero Jandaíra e do Açu.

Pode-se notax também o agrupamento distal $\left(-5^{0} / 00^{<}<0^{18}<-4^{0} / 00\right.$ e $25 \% \circ<\delta \mathrm{D}<30 \% 0$ ) do conjunto de poços do aquifero Açu con finado e que reúne as águas mais antigas ou seja teor de $\mathrm{C}^{14}<$ $13^{\circ} / 00 \bmod$.

Os poços 896-122, 899-56 e 974-41, aparentemente desloca dos para o interior da área de domínio do aquífero Açu, são am bos representantes de captação mista, nos aquíferos Jandaíra/ Açu.

Entre os poços tidos como do aquífero Jandaira e represen tados nas proximidades dos poços do aquífero Açu, deve-se obser var que os de nümero 896-4 e 897-44, embora estejam em área on de as cargas hidrăulicas do aquífero Açu são superiores às do aquífero Jandaira, podendo-se portanto prever mistura por apor te de äguas do aquífero Açu por drenança vertical ascendente, são, no entanto, de pequena profundidade $(80$ e $92 \mathrm{~m}$, respec tivamente) e se localizam em äreas de aluviões do rio Apodi-Mos 
soró. Assim sendo, é lícito supor tambëm a influência das águas contidas nesses aluviões, á semelhança dos poços de upane ma que estão no mesmo contexto, uma vez que se distribuem na mesma área destes.

E interessante notar que alguns poços, tais como 974-7 e 974-34 em Upanema, mesmo pertencendo ao aquífero Açu livre, não apresentam semelhança com as äguas do aquífero Jandaíra na sua composição isotópica, como se poderia esperar por estarem conti dos no mesmo contexto climático, ao passo que os poços da cida de de Açu (poço 975-26, s/no e 46) apresentam composição isotó pica próxima das águas meteóricas relativas aos meses de março e abril/70 na mesma cidade de Açu. Esse fato, aliado ao paralelismo das curvas pluviomētricas em estações da Bacia, representados parcialmente na FIGURA 43 (item B.2-d), leva a su por que embora possa haver diferença nas concentrações isotópi cas das chuvas, deve haver difexença nas águas de realimentação do aquifero Açu nas suas diferentes äreas de recarga, onde ora esta seria feita diretamente por águas meteóricas, ora por äguas fluviais vindas de sobre as rochas cristalinas situadas a sul, portanto com uma composição isotópica atípica para aquela região.

Na FIGURA 18 estão representados esquematicamente a equa ção da relação $\delta D$ e $\delta 0^{18}$ para as águas meteóricas, segundo CRAIG, ăguas meteöricas do nordeste, āguas subterrâneas da Bacia poti guar (aquíferosJandaira e Açu) e das ăguas subterrâneas do cris talino do nordeste.

Comparando-se as equações representativas das águas do cristalino com a das águas da Bacia Potiguar, observa-se atra vês do coeficiente angular da reta (Equações 2 e 4, FIGURA 13) que as mesmas sofreram evaporação antes de aportar no aquifero. o processo de evaporação teria sido porém mais intenso nas águas dos sedimentos comparativamente às ăguas do cristalino evi denciando portanto uma dinâmica diferente no processo de recarga.

SALATI et alii (1976) tendo encontrado a equação $\delta D=10+7,780^{18}$ pa ra as Bacias sedimentares do nordeste, concluíram que as ăguas pareciam não ter sofrido processo de evaporação antes da recarga e nem apōs a mesma, observando porēm que tal conclusão era contraditória com o valor estimado, em mais de $90 \%$, para os volumes evaporados apōs a precipitação. A equação ora encontrada 


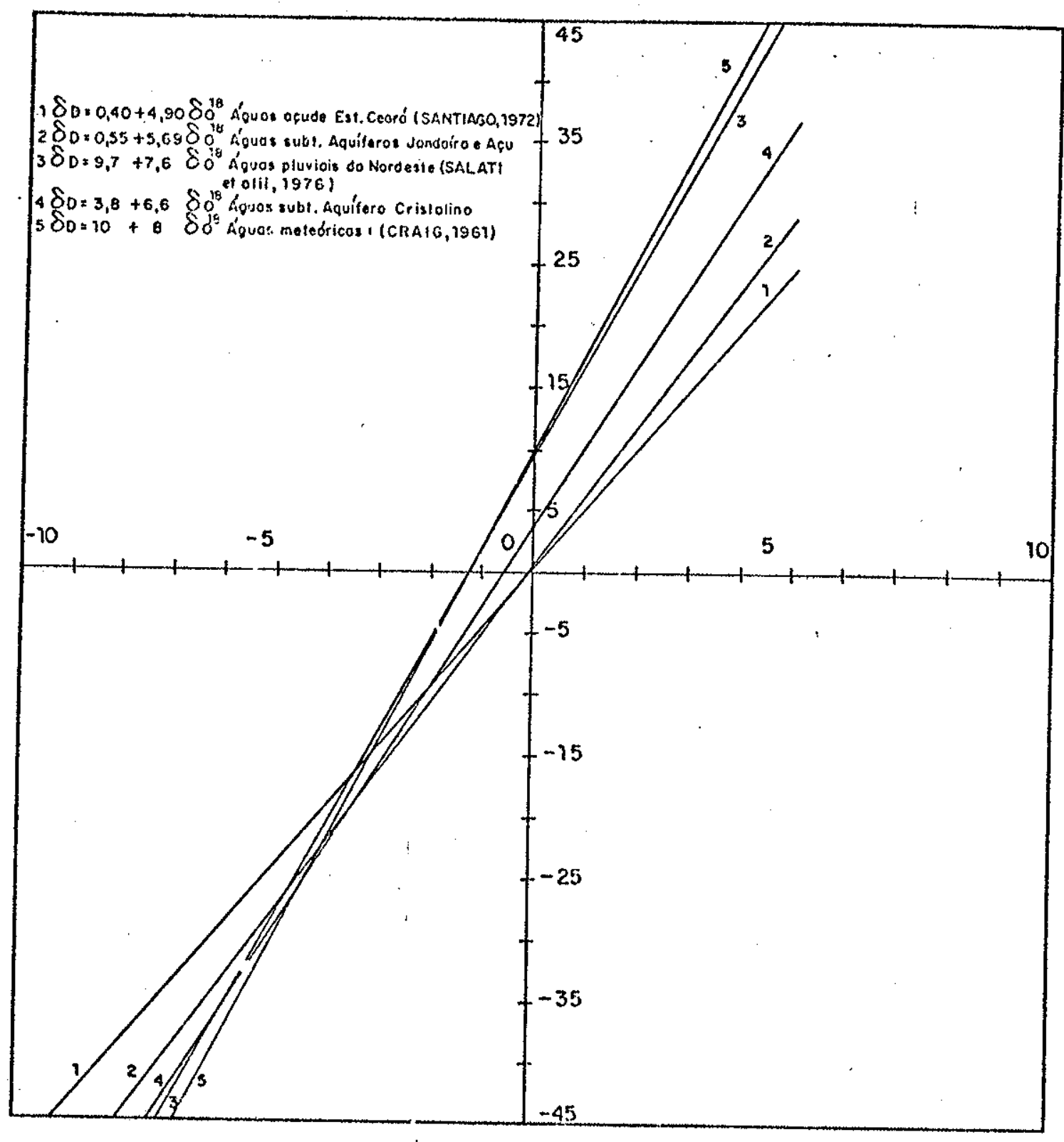

FIGURA 18 - Representação da relação $\delta D$ e $\delta 0^{18}$ em āguas meteóricas, superficiais e subterrâneas do nordes te brasileiro e meteöricas segundo CRAIG. 
(Equação 2 FIGURA 18) demonstra realmente não haver a contradi ção suspeitada pois evidencia uma forte evaporação das ăguas an tes de participarem das reservas desses aquiferos. A discrepân cia dos coeficientes encontrados talvez seja devida ao reduzido numero de dados utilizados naquela ocasião.

B) Idade das äguas do aquifero Jandaira

A determinação da idade das āguas subterrâneas representa tambëm um importante aspecto para a elaboração de planos de apro veitamento desses recursos, uma vez que as datações permitem a avaliação da velocidade de circulação das ãguas no aquífero e do coeficiente de realimentação dos mesmos.

Até o presente momento não se dispõe de dados de Carbono14 de águas do aquífero Jandaíra. Segundo MERCADo et alii (1976) as āguas do aquifero Jandaira parecem ser modernas, de acordo com seus teores de Trítio significativos. 


\section{O AQUIFERO JANDAIRA}

\subsection{Caracteristicas Dimensionais}

Espessura: o aquifero Jandaíra se instala na porção supe rior da sequência carbonātica da Formação Jandaîra que apresen ta grande variação litológica, tanto vertical como horizontal. - aquifero se apresenta, de uma maneira geral, como uma camada sub-horizontal com espessuras variando de 50 a $250 \mathrm{~m}$. A espes sura máxima de $250 \mathrm{~m}$ aqui admitida, se refere à camada aquífera e não à espessura da unidade litoestratigráfica de mesmo nome. Admitiu-se a espessura de $250 \mathrm{~m}$ pelo fato de que as fraturas, ca vernas e mesmo perdas de circulação descritas em relatórios de perfurações efetuadas na porção continental da bacia, são ine xistentes a profundidades superiores a $300 \mathrm{~m}$, ou seja, na por ção inferior da Formação Jandaíra que, em sua parte ocidental e central é constituída por calcários lajeados, superpostos por calcários conchiferos com intercalações de calcārios compactos e na porção oriental, pela presença exclusiva dos calcärios com pactos.

Extensão: as rochas carbonāticas que constituem o aquífero Jandaira abrangem uma superficie de $17756 \mathrm{~km}^{2}$, dos quais cerca de $15598 \mathrm{~km}^{2}$ estão no Estado do Rio Grande do Norte e apenas $2158 \mathrm{~km}^{2}$ no Estado do Ceară. Nesse dominio estão incluĩas as äreas de cobertura dos sedimentos terciärios do Grupo Barreiras, e quaternārios dos aluviöes e dunas, que abrangem cerca de .... $5980 \mathrm{~km}^{2}$.

- limite leste de ocorrência da Formação Jandaira como aquífero é desconhecido e, de uma maneira aproximativa, a leste de uma linha que une as cidades de pureza e Touros, se observa um aumento significativo da espessura do aquífero Barreiras a ele sobreposto, que permite antever supremacia quase absoluta desse aquifero, relativamente ao aquifero Jandaira. Tais fatos, aliados ao desconhecimento geolögico-estrutural da ärea a les te dessa linha até o presente momento, levou à desconsideração da Formação Jandaira como aquífero nessa ārea. Desse modo, para efeito de cálculos futuros, a superfície de domínio do aquífero Jandaíra aqui considerada é de $16278 \mathrm{~km}^{2}$, correspondentes à ärea da Formação Jandaíra a oeste dessa linha, inclusive as por 
ções recobertas pelos seđimentos terciärios e quaternärios.

Limites: o aquífero Jandaíra é limitado na base por uma camada pouco permeável constituída por arenitos e siltitos argi losos, argilitos, folhelhos, margas, calcarenitos e calcārios compactos, pertencentes à porção superior da Formação Açu e à porção inferior da Formação Jandaíra. O comportamento hidrāulico dessa camada, é responsável pela interconexão entre esses aquí feros (FIGURA 30, item 7.5.2).

As seções hidrogeológicas apresentadas no ANEXO D eviden ciam as relações de fronteira do aquífero Jandaira.

com um päleo-relevo bastante irregular, evidenciado atra vés de perfis litolögicos de poços, a Formação Jandaíra, junto à costa norte, ē recoberta por uma faixa de sedimentos terciä rios, associados a sedimentos quaternārios, que se apresenta com largura e espessura bastante variáveis (MAPA 11). A. maior largura dessa faixa é encontrada na área da serra do Carmo e do Mel, com cerca de $45 \mathrm{~km}$, e a menor, a norte da cidade de Pedra Grande, com $4 \mathrm{~km}$.

Há evidências de que em algumas āreas existem sedimentos de mais de uma formação do terciārio e não somente do Grupo Barreiras, porëm, na ausência, até o momento, de separação entre as mesmas, no mapa de contorno estrutural desses sedimentos (MA $\mathrm{PA}$ 11) e no de isópacas (MAPA 12), estes foram referidos. sim plesmente como sedimentos de cobertura da Formação Jandaíra.

Embora esses sedimentos apresentem espessuras pouco expres sivas na porção oeste e central da bacia (as maiores espessuras do grupo Barreiras estão na porção leste, portanto fora do domí nio, considerado), podem no entanto, em algumas äreas, associa dos aos sedimentos aluvionares e dunares, se constituir em paco tes mais espessos onde se instala secundariamente 0 sistema aquífero denominado Dunas-Barreiras (MANOEL FILHO, 1971).

O sistema aquífero Dunas-Barreiras è limitado na base por uma camada pouco permeävel que o separa do aquífero Jandaíra, conferindo a este, caráter de semiconfinamento nessas āreas (item 7.2). Tal sistema também se constitui em discreta fonte de recarga do aquifero Jandaíra, influenciando ainda na caracte rização e distribuição espacial dos componentes quimicos e parâ metros físico-químicos das suas äguas (item 8.4). 
Apesar da área dos sedimentos de cobertura ser de $5980 \mathrm{~km}^{2}$ a superfície do sistema aquífero Dunas-Barreiras com cargas su periores às do aquífero Jandaíra é de aproximadamente $2033 \mathrm{~km}$. Assim dimensionado, em $14245 \mathrm{~km}^{2}$ o aquífero Jandaíra foi consi derado hidraulicamente livre.

\subsection{Características das camadas semj-confinantes}

a) Camada Semi-confinante da Base do Aquifero Jandaira

o aquitardo da base do aquífero Jandaíra é constituído por diferentes litologias, correspondentes à base da Formação Jan daíra e ao topo da Formação Açu e que, em geral, da base para - topo são representadas por argilas arenosas, argilas silto sas, argilitos, folhelhos, margas, calcarenitos e calcários com pactos, com eventuais intercalações de lentes arenosas a dife rentes niveis.

Esse aquitardo funciona hidraulicamente como camada semiconfinante do topo do aquífero Açu, e dependentemente das dife renças de cargas hidräulicas entre este e o Jandaira, é respon sāvel pela entrada, por arenança vertical ascendente, ou saída por drenança vertical descendente de ägua deste ültimo (item 7.7). Sua espessura máxima é da ordem de $800 \mathrm{~m}$, na parte cen tral da Bacia (IPT, 1982).

Pela inexistência de valores calculados de permeabilidade, com base na sua composição litológica e por comparação com lito logias semelhantes, o IPT, "ibidem", admitiu para este aquitar do, uma permeabilidade da ordem de $4,2 \times 10^{-7} \mathrm{~m} / \mathrm{h}$. Esse valor de permeabilidade, que representa tambēm a que melhor ajuste proporcionou quando da simulação do modelo hidráulico do aquífe ro Açu efetuado por aquele Instituto, foi aqui utilizada para os cálculos do balanço hídrico do aquífero (item 7.7).

b) Camada Semi-confinante do topo do Aquifero Jandaira

Como exposto anteriormente, (item 7.1) apenas uma pequena porção da Formação Jandaỉxa na sua faixa litorânea, è recober ta pelos sedimentos terciários do Grupo Barreiras (?) e depósitos quaternários aluvionares e dunares. No MAPA 11 está repre sentado o contorno estrutural da base da cobertura da Porrnaçio Jandaira nessa faixa e no MAPA 12 as espessuras desses sedimen tos. 
A análise de perfis de poços localizados nessas áreas reve la a presença de uma camada semi-permeável entre os calcärios Jandaíra e os sedimentos de cobertura, constituída por leitos predominantemente argilosos e às vezes margosos, com espessura variando desde 6 até $52 \mathrm{~m}$, tendo-se admitido, para efeito de cálculos envolvidos no balanço hídrico do aquífero Jandaíra, (item 7.7) uma espessura média da ordem de $15 \mathrm{~m}$. Tal camada, po de ser correspondente à porção basal da Formação serra do Mar tins do Grupo Barreiras, ou mesmo representar o resultado final da decomposição da capa dos calcários Jandaíra, que teria origi nado então depósitos argilosos.

A observação conjunta do mapa piezomëtrico do aquífero Jan daira (MAPA 14) e do mapa que contēm a cota do nível d'ägua de poços e cacimbas localizados no sistema Dunas-Barreiras (MAPA 15) permitiu verificar que este último apresenta cargas hidráulicas superiores às do aquífero Jandaíra, em média da ordem de $5 \mathrm{~m}$. Ao que tudo indica, esses depösitos argilosos funcionam hidrau licamente como camada semiconfinante do topo do aquífero Jandaí ra nas áreas onde o mesmo se encontra recoberto pelos sedimen tos terciários e quaternārios, o que permite a existência . de cargas hidráulicas mais elevadas nesse sistema aquifero, respon sãvel assim por uma parcela de ägua de alimentação do aquífero Jandaira, por drenança vertical descendente (itens:7.5.3 e 7.7.6).

Face à falta de dados de permeabilidade dessa camada semi confinante, para os cálculos do balanço hídrico do aquífero Jan daíra (item 7.7) em comparando-se com litologias semelhantes, ad mitiu-se o valor de $4,0 \times 10^{-7} \mathrm{~m} / \mathrm{h}$ para a mesma.

\section{7:3 Caracteristicas hidrodinâmicas}

A avaliação dos recursos hídricos subterrâneos de um aquí fero não pode prescindir do conhecimento dos valores dos parâme tros hidrodinâmicos em toda a sua ārea de domínio, por permiti rem a estimativa do seu potencial de armazenamento, de produção e dos volumes escoados. As caracteristicas hidräulicas do aquí fero Jandaira obtidas e analisadas nesta monografia foram a va zão especifica $(\Omega / s)$ e a transmissividade ( $T$ ). 


\section{Vazão especifica}

Dos 853 poços do aquífero Jandaíra cadastrados no Estado do Rio Grande do Norte (IPT, 1982) 478 deles possuíam dados de vazão específica.

A FIGURA 19 apresenta o histograma de frequência dos valo res de vazão específica.

Como se pode notar os valores abrangem uma amplitude bas tante grande, de 0,01 atē $48,0\left(\mathrm{~m}^{3} / \mathrm{h}\right) / \mathrm{m}$, com mëdia de $4,69\left(\mathrm{~m}^{3} / \mathrm{h}\right) / \mathrm{m}$, o desvio padrão de 7,88 é porém elevado, ultrapassando mesmo o valor da mëđia.

A tēcnica exploratōria do diagrama de juntas ("boxplot") (FIGURA 20) revela que 75\% dos valores de vazão específica estão compreendidos no intervalo 0,01 até $6,20\left(\mathrm{~m}^{3} / \mathrm{h}\right) / \mathrm{m}$. Vazões entre 15,3 e $24,5\left(\mathrm{~m}^{3} / \mathrm{h}\right) / \mathrm{m}$ são valores externos e os valores superio res a $24,5\left(\mathrm{~m}^{3} / \mathrm{h}\right) / \mathrm{m}$ são pontos soltos e portanto de probabilida de baixa de ocorrência.

Na FIGURA 21 é apresentado o gräfico de distribuição de probabilidade lognormal da variação $Q / s$ e na TABELA 4 , ANEXO $B$ as frequências correspondentes, podendo-se verificar que a me diana é de 0,69 , ou seja, 50\% dos dados de vazão específica são inferiores a $\left.0,69\left(\mathrm{~m}^{3} / \mathrm{h}\right) / \mathrm{m}\right)$.

Na FIGURA 22 é ainda apresentado o gráfico de đistribuição de probabilidade lognormal da variável $\Omega / s$ em 9 intervalos de classes. Pode-se admitir a existência de praticamente 4 popula ções de vazões especificas: uma de baixos valores, duas de valo res intermediärios e uma de valores altos. Essas populações pro vavelmente estejam refletindo a composição litológica e o grau de carstificação dos maciços calcários nos locais dos poços.

A relação entre os valores de vazão específica e os de pro fundidade dos poços é apresentada na FIGURA 23 podeño-se no tar, pelo baixo valor do coeficiente de determinação, que prati camente inexiste uma relação direta entre esses parâmetros, a menos de uma discreta tendência de redução de $\Omega / s$ com o apro fundamento dos poços, evidenciando-se assim o caräter hetero gêneo do aquî́fero.

$\mathrm{Na}$ FIGURA 24 estão representados os valores acumulados das mēdias das vazões especîficas por intervalos de $10 \mathrm{~m}$ de profundidade, po dendo-se notar então claramente que as maiores vazões especifi 


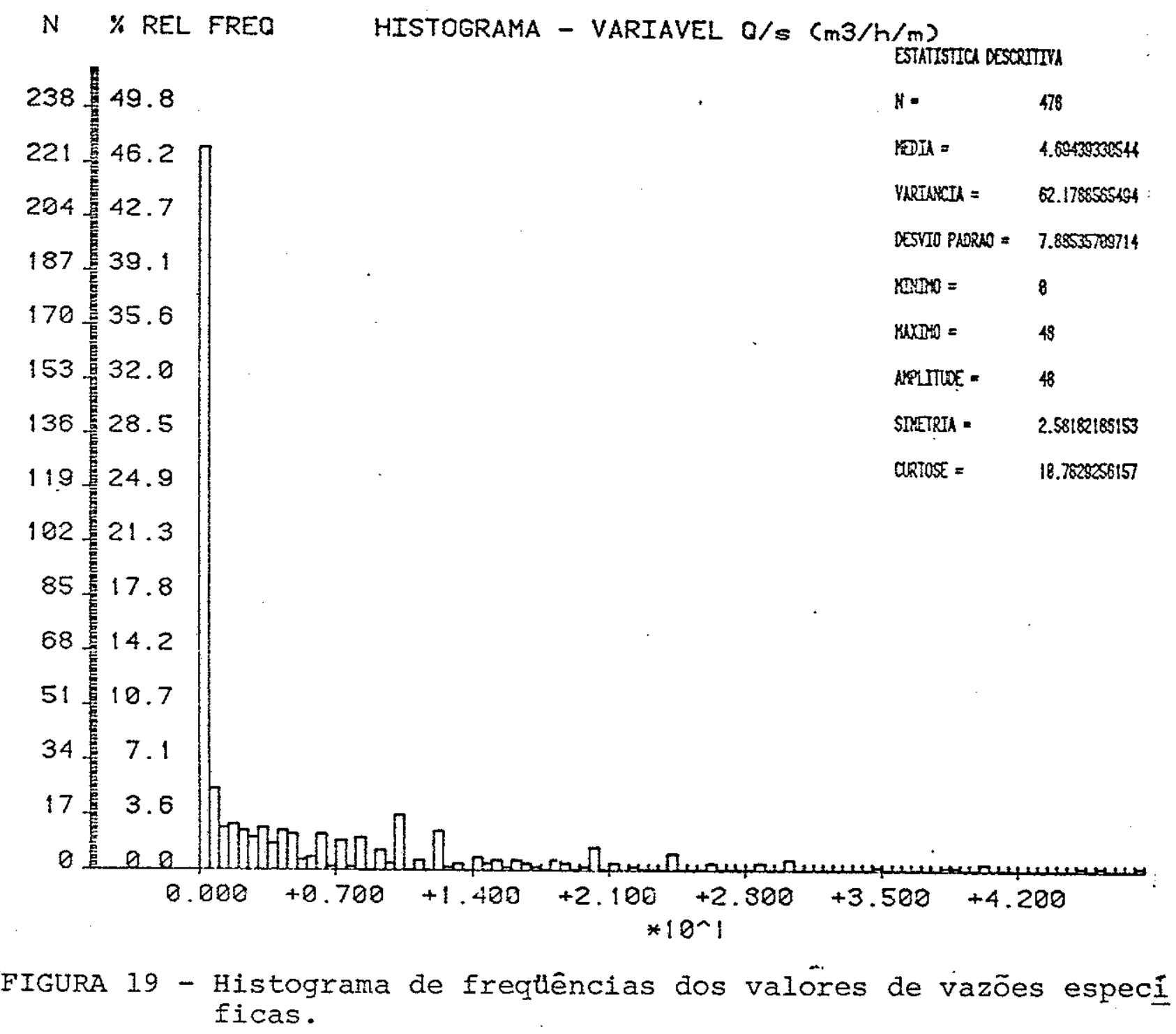


viariāvel $=$ vazão específica

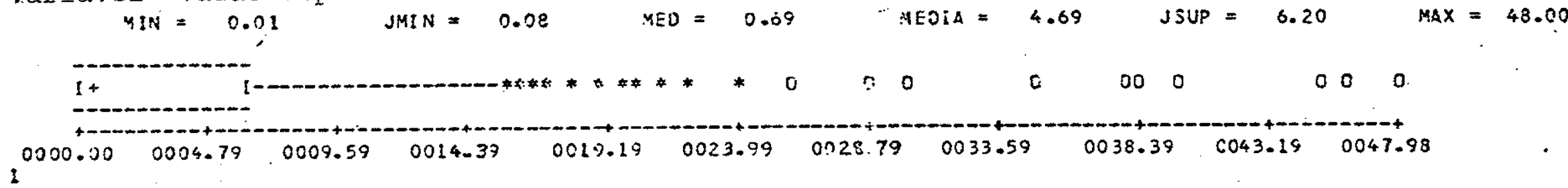

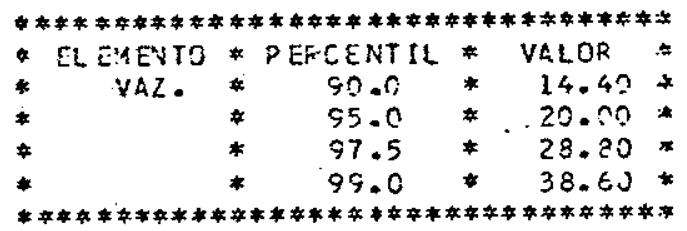

VALORES SUPERIOFES AO PERCENTIL 90

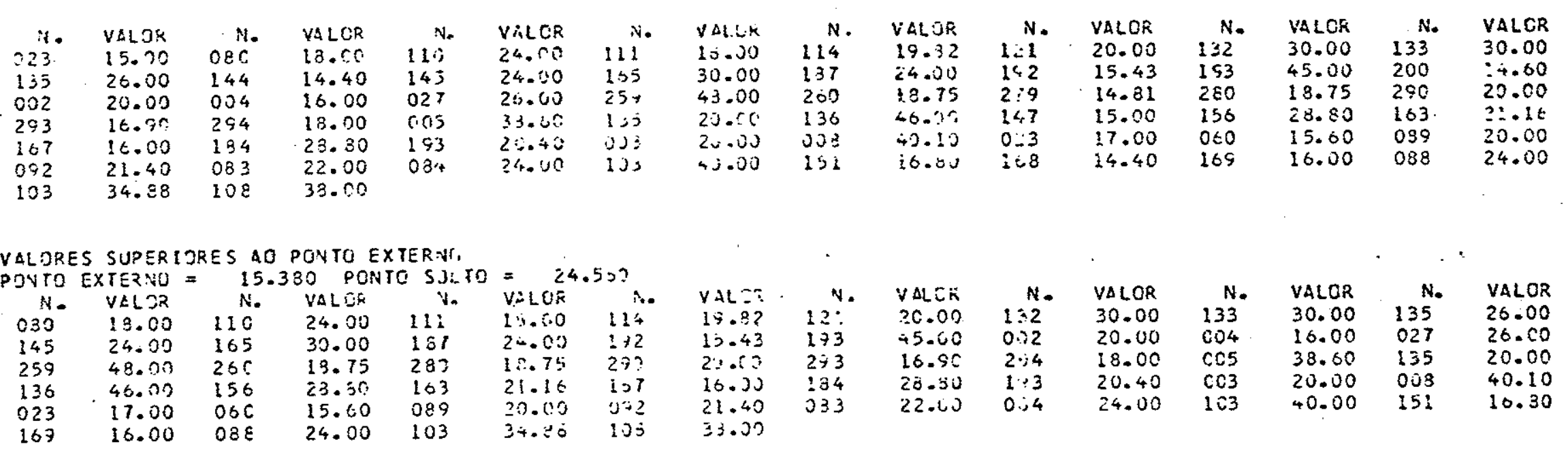

FIGURA 20 - Diagrama de juntas ("boxplot") dos valores de vazão específica. 


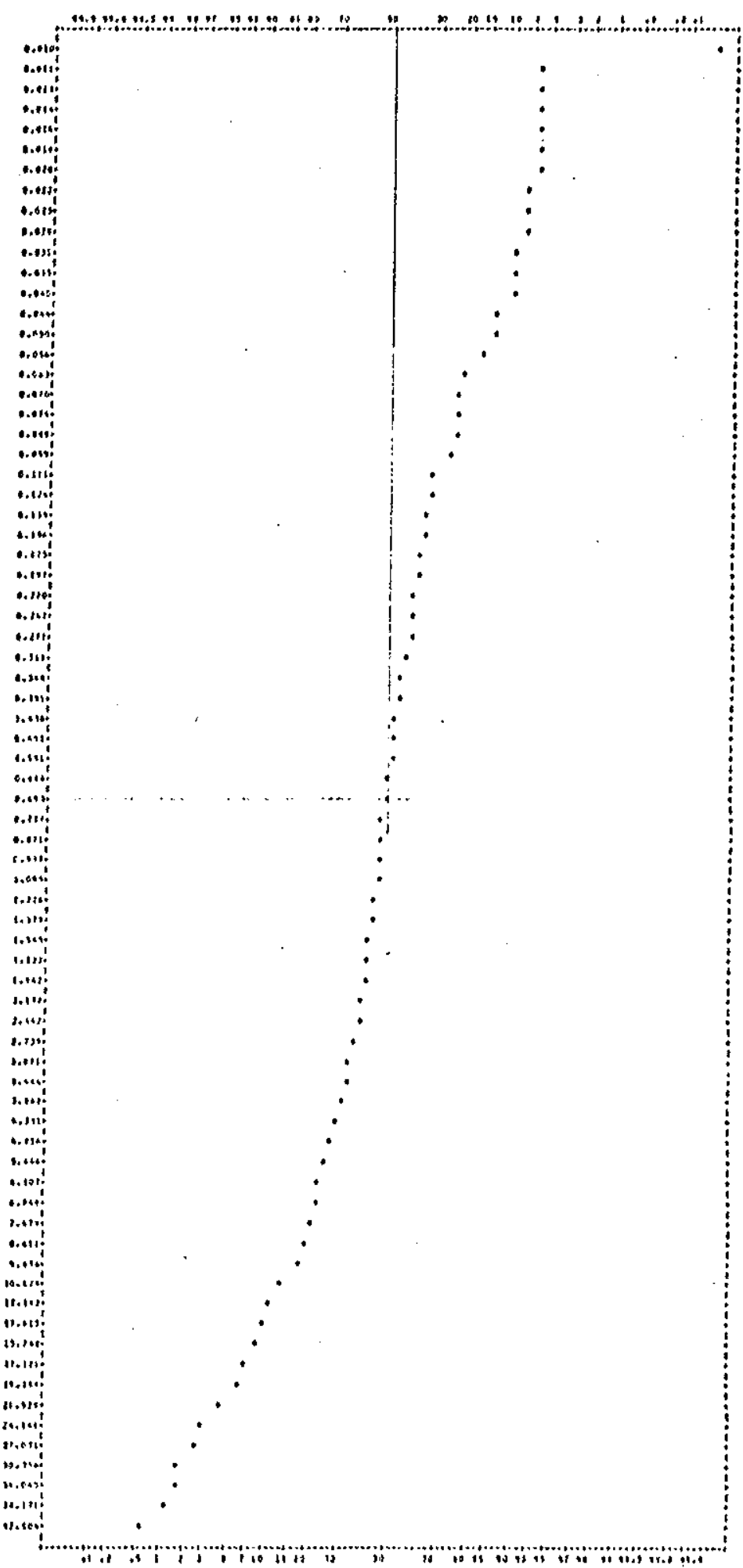

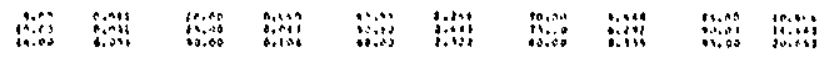

FIGURA 21 - Distribuição de probabilida de lognormal dos valores de vazão específica. 
Grä́fico de probabilidade da variāvel=vazão específica

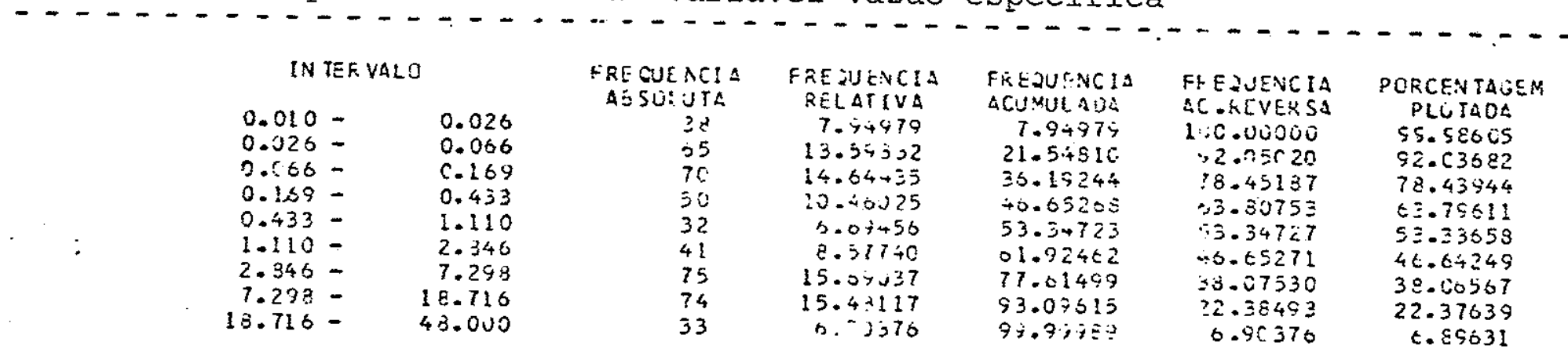

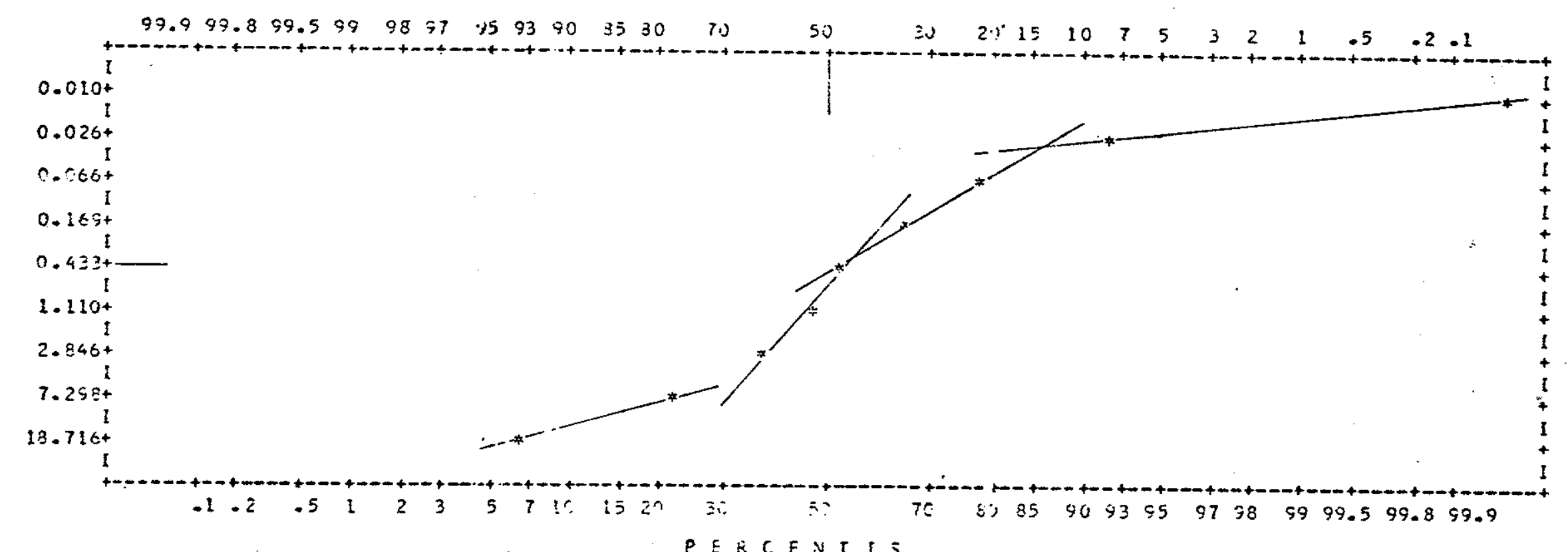

\begin{tabular}{|c|c|c|c|c|c|c|c|c|}
\hline $\begin{array}{r}5.00 \\
10.00 \\
16.00\end{array}$ & $\begin{array}{l}0.020 \\
0.032 \\
0.0449\end{array}$ & $\begin{array}{l}20.00 \\
25.00 \\
30.00\end{array}$ & $\begin{array}{l}0.101 \\
0.010 \\
0.025\end{array}$ & $\begin{array}{l}40.00 \\
30.02 \\
60.00\end{array}$ & $\begin{array}{l}0.265 \\
2.771 \\
2.456\end{array}$ & $\begin{array}{l}70.00 \\
75.100\end{array}$ & $\begin{array}{l}5.137 \\
6.556 \\
9.057\end{array}$ & $\begin{array}{l}84.00 \\
96.00\end{array}$ \\
\hline
\end{tabular}

FIGURA 22 - Distribuição de probabilidade lognormal para 9 classes de valores de vazäo especifi 
cas se encontram em poços com profundidades entre 20 e $140 \mathrm{~m}$. Os novos acréscimos a partir de $270 \mathrm{~m}$ talvez se devam ao reduzi do número de dados.

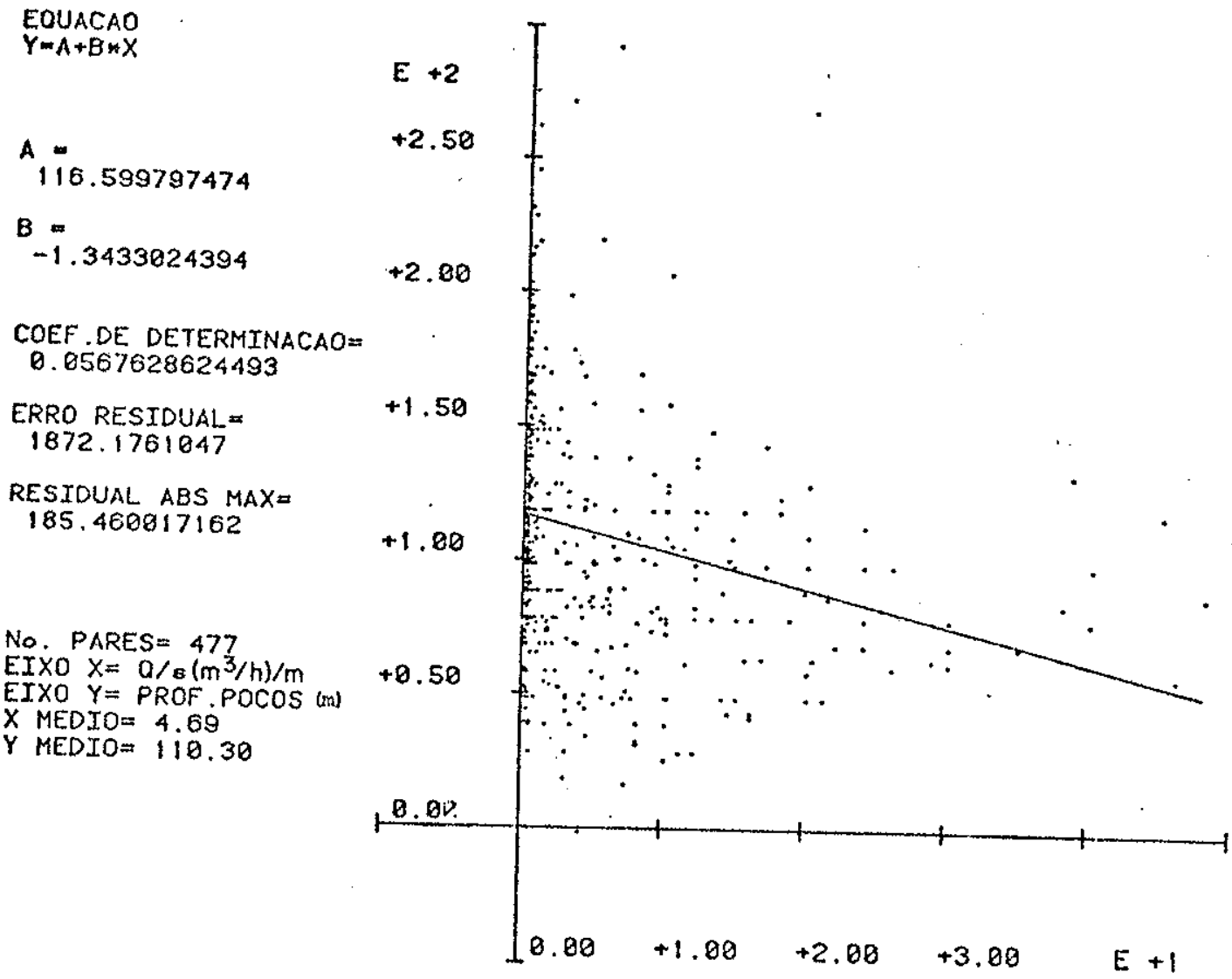

FIGURA 23 - Relação entre vazão específica e profundidade dos poços.

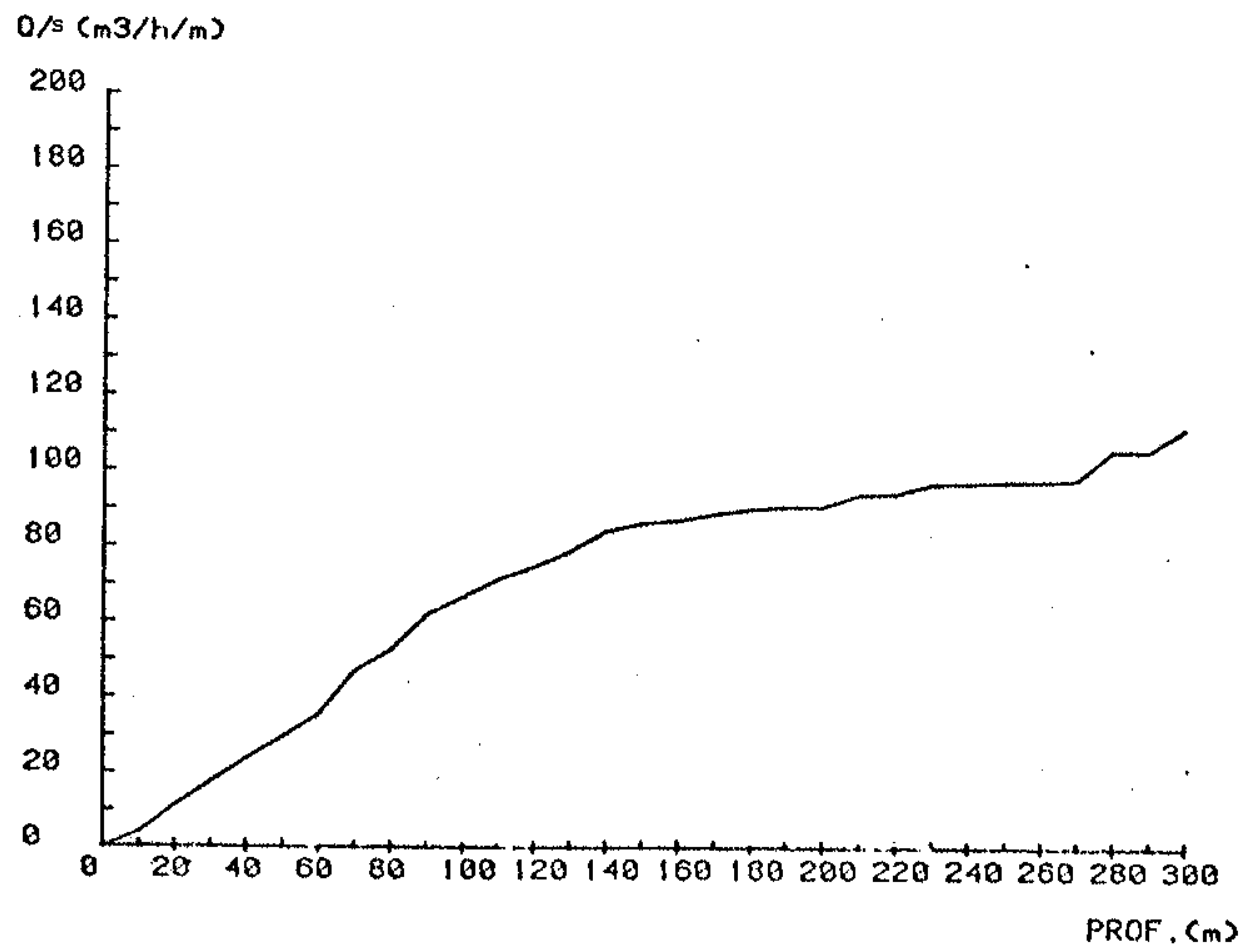

FIGURA 24 - Curva acumulativa das médias das vazões especificas em intervalos de $10 \mathrm{~m}$ de profundidade. 
Fol analisada tambērn a relação entre os valores de vazão específica e os de profundidade dos niveis d'ägua estáticos dos poços, representada na FIGURA 25 concluindo-se ainda por uma falta de correlação entre esses parâmetros, notando-se apenas uma leve tendência de redução de vazão específica com o aprofun damento dos níveis.

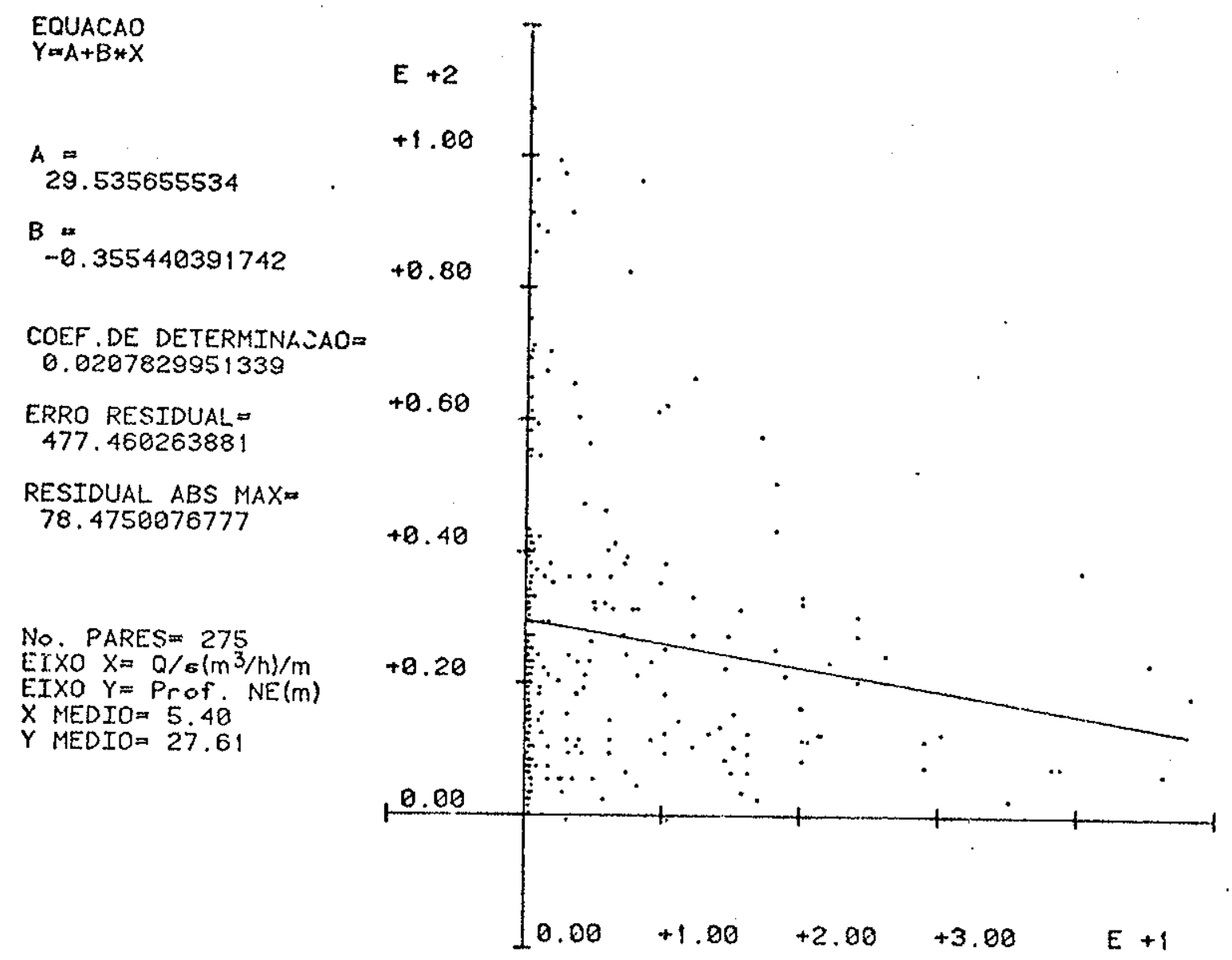

FIGURA 25 - Relação entre vazão específica e profoundidade dos ní veis d'água.

O comportamento espacial dos valores de vazão especifica é apresentado no MAPA 13. As isolinhas de vazão específica reve lam bem o caráter heterogêneo do aquífero, evidenciando äreas contiguas com valores de vazão especifica bastante discrepantes. Pode-se observar ainda que há uma estreita correlação entre os altos valores de vazão específica e a presença de falhamentos. Esse fato é explicado pelos processos genéticos de carstifica ção, umà vez que geralmente hä uma associação entre ambas, em que as redes cārsticas são escavadas sobre as descontinuidades dos maciços calcārios. 


\section{Transmissividade}

Com o objetivo de obter os valores de transmissividade do aquífero Jandaíra foram interpretados registros de ensaios de bombeamento ou de recuperação de nível executados pela CDM em 74 poços tubulares por ela construídos. Como em todos os ensaios as medidas de nivel d'ägua foram tomadas no pröprio poço duran te o bombeamento ou durante a recupexação, somente foi possível a obtenção de valores de transmissividade (T) do aquífexo, não tendo sido possível portanto a obtenção do coeficiente de resti tuj.ção (S).

Entre os ensaios interpretados foram selecionados 7 deles. considerados representativos do aquifero, cujos perfis constru tivos e litológicos, registros das medidas de nível durante os ensaios bem como os gräficos representativos dos rebaixamen tos em função dos tempos são apresentados no ANEXo $\mathrm{C}$.

A interpretação dos dados foi conduzida mediante a aplica ção do método simplificado de Jacob, para os rebaixamentose pelo método de Jacob-Theis, para a recuperação. Assim, os valores de transmissividades foram calculados atravês das seguintes eq̧uações:

$T=\frac{0,1830}{\Delta s} \log t$, paxa os rebaixamentos, ou então:

$T=\frac{0,183 Q}{\Delta s^{\prime}} \cdot \log t / t^{\prime}$, para a recuperação, onde:

$\mathrm{T}=$ transmissividade $\left(\mathrm{m}^{2} / \mathrm{h}\right)$;

$Q=$ vazão de bombeamento $\left(\mathrm{m}^{3} / \mathrm{h}\right)$;

$\Delta \mathbf{s}=$ rebaixamento do nivel no intervalo de tempo considerado (m);

$\Delta \mathbf{s}^{\prime}=$ rebaixamento residual no intervalo de tempo de recupera̧̧ão considerado (m);

$t=$ tempo decorrido desde o início do bombeamento (min) e, $t^{\prime}=$ tempo decorrido durante a recuperação de nível (min).

Na TABELA 5 (ANEXO B) são apresentados os valores de trans missividade $(T)$ e de vazão especifica $(\Omega / s)$ dos poços ensaiados. No histograma da FIGURA 26 estão representadas as frectien cias dos valores de transmissividade assim obtidos. 


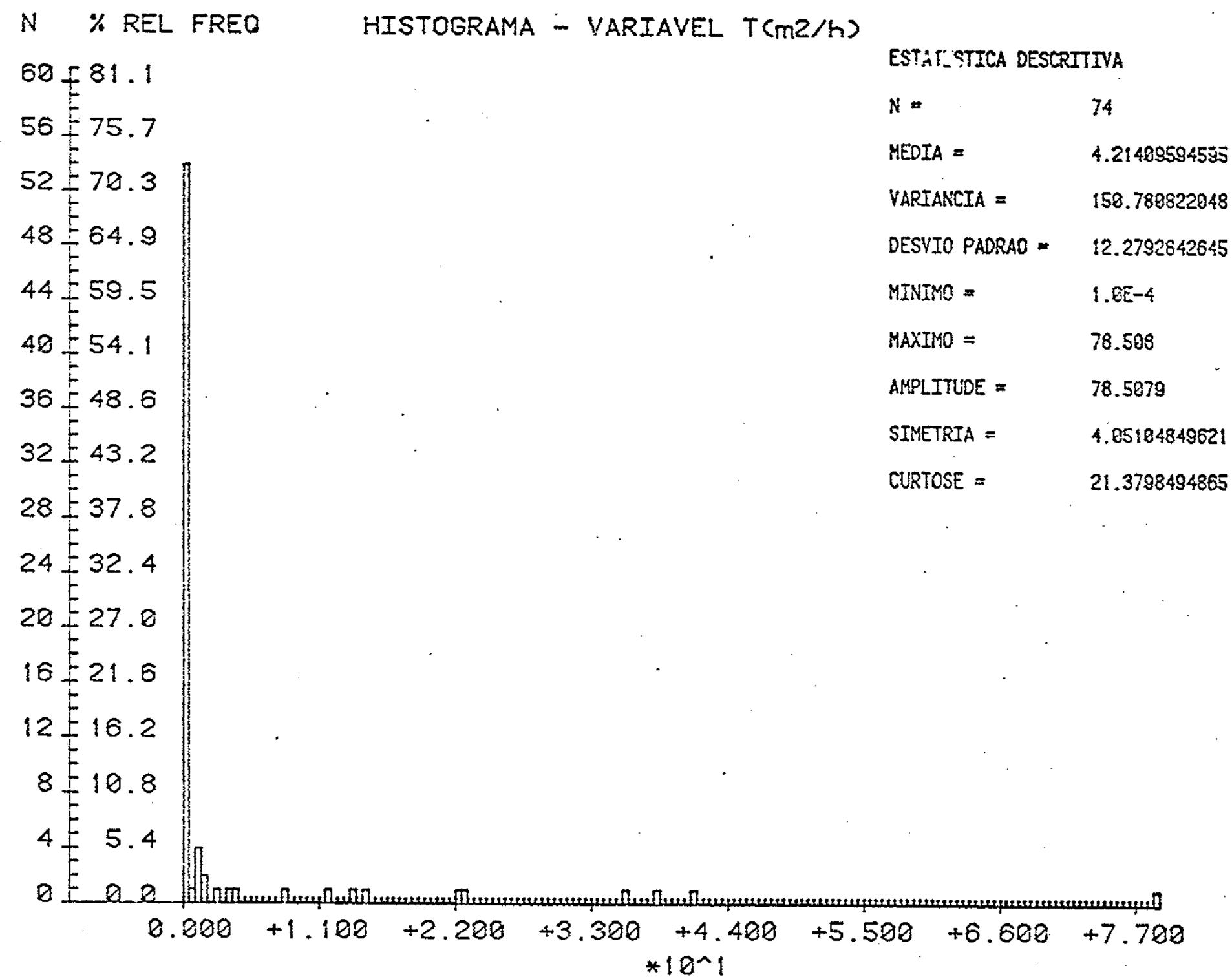

FIGURA 26 - Histograma de frequências de valores de transmissividade obtidos através de ensaios de bombeamento. 
Com o objetivo de amenizar problemas decorrentes da escas sez e má distribuição dos dados de transmissividade, tentativa foi feita no sentido de completar o quadro desses valores, esta belecendo-se a relação entre a transmissividade ( $T$ ) e a vazão específica (Q/s) disponíveis (FIGURA 28).

Obteve-se assim a relação entre a transmissividade e a va zão específica para poços do aquífero Jandaíra, expressa pela seguinte equação:

$$
\log \mathrm{T}=-0,37+1,14 \log 0 / \mathrm{s}
$$

Essa relação foi aplicada aos 404 poços restantes que pos suíam somente valores de $\Omega / s$, permitindo a construção do histo grama da FIGURA 27.

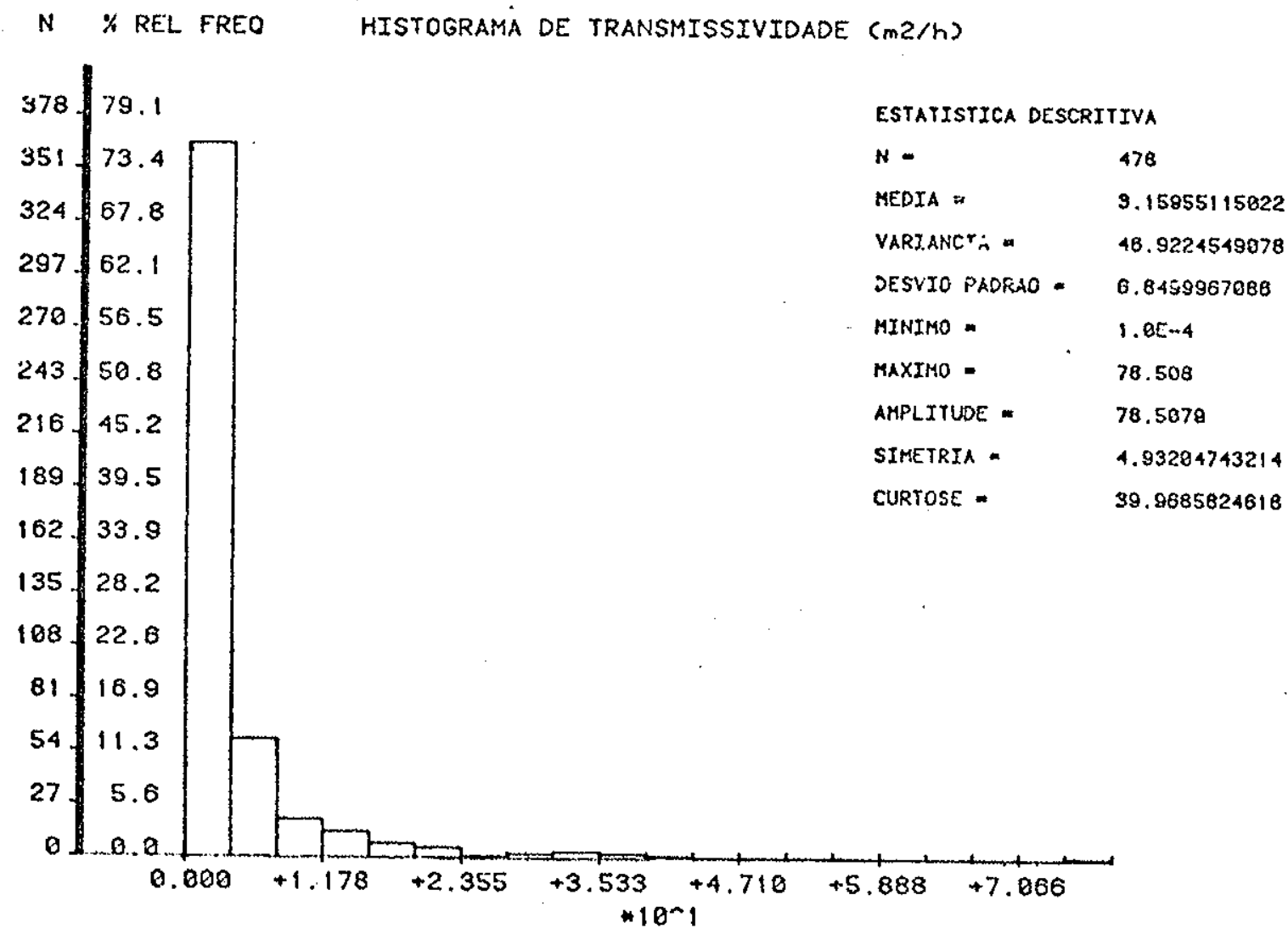

FIGURA 27- Histograma de frequências de valores de transmissivi dade obtidos através de ensaios e calculados através da relação $\mathrm{T} \times \Omega / \mathrm{s}$.

Os valores característicos de vazão específica e de trans missividade assim obtidos são resumidos no QUADro 10 a seguir. 


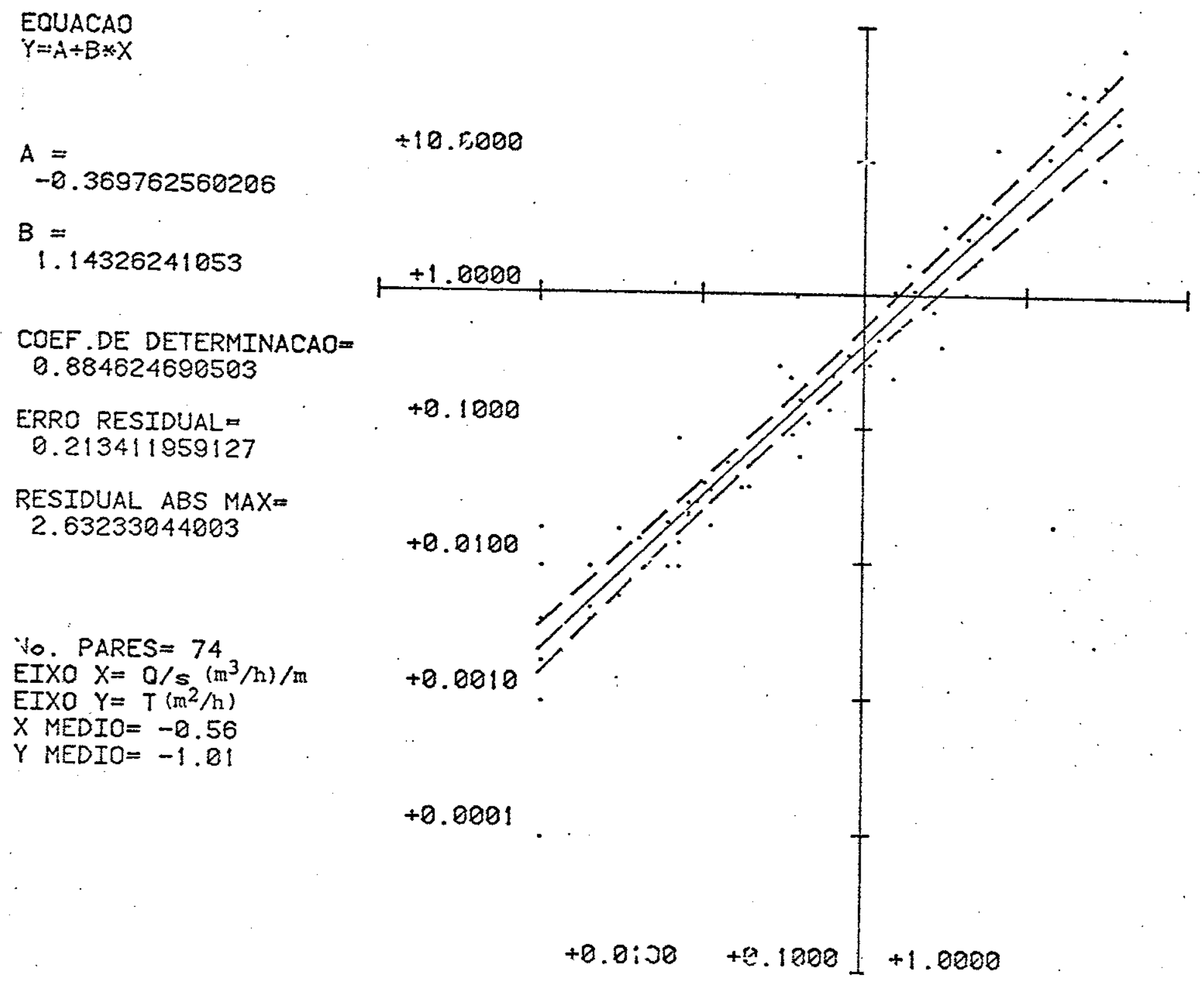

FIGURA 28 - Relação entre transinissividade e vazão específica 
A equação obtida foi utilizada tambēm na avaliação dos vo lumes escoados pelos exutörios naturais do aquífero (item 7.7.2) e, devido ao grande nümero de poços com valores de $\Omega / s$ e à sua distribuição regular foi possivel se proceder a uma compartimentação bastante detalhada das frentes de descarga do aquífero.

Foram calculados ainda os valores de permeabilidade (K), porém de um modo bastante aproximativo, através da equação:

$$
\mathrm{K}=\mathrm{T} / \mathrm{b} \text {, onde: }
$$

K - permeabilidade $(\mathrm{m} / \mathrm{h})$;

T - transmissividade $\left(\mathrm{m}^{2} / \mathrm{h}\right) ; e$

b - espessura saturada do aquifero.

As espessuras saturadas nos locais dos poços ensaiadas foram estimadas a partix do mapa de isōpacas da Formação Jandaira (MAPA 5) e da profundidade dos níveis estáticos dos poços. Os valores constam do QUADRO 10 a seguir.

\begin{tabular}{|l|c|c|c|c|}
\hline \multirow{2}{*}{ Parâmetro } & \multicolumn{4}{|c|}{ Valores } \\
\cline { 2 - 5 } & mínimo & máximo & médio & desvio paãrão \\
\hline Vazão específjca $\left(\mathrm{m}^{3} / \mathrm{h}\right) / \mathrm{m}$ & 0,01 & 48,0 & 4,69 & 7,88 \\
Transmissividade $\left(\mathrm{m}^{2} / \mathrm{h}\right)$ & $1 \times 10^{-4}$ & 78,5 & 3,15 & 6,84 \\
Permeabilidade $(\mathrm{m} / \mathrm{h})$ & $7 \times 10^{-7}$ & 1,3 & $3,6 \times 10^{-2}$ & - \\
& & &
\end{tabular}

QUADRO 1.0 - Parâmetros estatisticos de vazão especifica, trans missividade e permeabilidade. 


\subsection{Escoamento Natural}

a) As descontinuidades do meio aquifero

As estruturas geológicas presentes nos maciços calcārios desempenham papel duplo na hidrologia cárstica uma vez que de las depende a maior ou menor ação dos mecanismos de carstifica ção e tambëm porque influenciam na dimensão das redes dos siste mas cársticos. Assim, as descontinuidades lineares presentes na Formação Jandajra, tais como as falhas e as diaclases identifi cadas em superficie (item 5.3.6), juntamente com o relevo, se im põem sobre o comportamento hidräulico do aquífero Jandaíra, tan to atravēs de suas direções e comprimentos como também através de suas frequências e densidades.

Além das descontinuidades lineares, os calcários da Forma ção Jandaîra apresentam indícios de carstificação cuja frequên cia está relacionada também com a sua composição litológica.

Todas as rochas calcarias cujo teor em $\mathrm{CaCO}_{3}$ é superior a $70 \%$ são susceptíveis a fenômenos de carstificação. A maioria das grandes redes cärsticas porēm se desenvolve em formações cujo teor em $\mathrm{CaCO}_{3}$ está próximo de 99\%. (THÉROND, 1973). Teores elevados em componentes insolüveis são, entretanto, um freio ao desenvolvimento de redes cársticas; assim é que os mais inten sos processos de carstificação da Formação Jandaira são encontrados nas äreas de calcários e dolomitos puros (MENor et alii., 1980), estando ausentes na zona central da Bacia onde esses au tores encontraram elevados valores de R.I. (Residuo Insolúvel), refletindo maiores contribuiçẽos de componentes terrigenos du rante a sedimentação dos calcārios Jandaỉra.

Formas exocārsticas como as dolinas, são encontradas em cua se todo o domínio dos calcários, mesmo onde estes são cober tos pelos sedimentos do Grupo Barreiras; lapiaz estão presentes em toda a Chapada do Apodi, sendo conspícuas porém em Maxixe, à cerca de $50 \mathrm{~km}$ a oeste de Mossoró. Formas exocársticas como fur nas, cavernas e sumidouros são encontradas em váxias localidades sendo porēm notörias em soledade, no municỉpio de Apodi, em Mo rorö, à $10 \mathrm{~km}$ a oeste de pedra Grande, e também en Maxixe (MAPA 1).

Nos exutórios do aquỉfero junto ao mar deve haver intensifi cação dos processos de carstificação pelo aumento da agressividade das águas nas zonas de misturas destas com a ägua maxinha. (THRAILKILI, 1968). 
b) Sistemas de fluxo

Consideradas as descontinuidades lineares (item 5.3.6), as evidências de carstificação, a grande variação espacial da cons tituição litológica dos calcários Jandaíra (item 5.3.6) e ainda os valores de vazão especifica e de transmissividade desses cal cários (item 7.3), pode-se concluir que o meio aquífero, quando analisado a nivel de detalhe, se apresenta heterogêneo e hi draulicamente anisotxópico, promovendo circulação tipicamente cārstica no seu interior, ou seja, um meio descontínuo com a circulação de ägua se processando essencialmente através de fen das e canais, alēm de que muitas vezes parte do fluxo se proces sa atravës das camadas arenosas presentes no interior da sequên cia carbonática. Quando analisado porëm em sua extensão e volu me regionais, como é o caso deste estudo (escala 1:500 000), po de-se-lhe atribuir constituição homogênea e comportamento iso trōpico.

Como a Formação Jandaíra se comporta como um grande platô calcärio de estrutura praticamente horizontal, o sistema de fis suração (diaclasamento) perpendicular às juntas, garante nesse caso, o aprofundamento das äguas (movimento vertical descenden te), enquanto que as juntas, permitindo o estabelecimento dos condutos horizontais de comunicação, garantem a circulação em direção aos exutórios (movimento horizontal), nas zonas mais pro fundas.

c) Areas preferenciais de recarga

Observando-se o mapa piezométrico (MAPA 14) pode-se identi ficar várias āreas preferenciais de recarga do aquífero Jandaí ra. Caracteristicamente livre, o aquífero apresenta em todas as āreas, coincidência entre os divisores de āguas subterrâneas e superficiais, evidenciando dessa maneira, a influência do rele vo sobre a sua superficie piezomëtrica. Essas äreas são a se guir, de oeste para leste, nominalmente identificadas e têm cita das as suas cargas hidräulicas mäximas:

- a oeste do rio Apodi-Mossoró;

- áxea a leste de Baraünas - $125 \mathrm{~m}$;

- ărea de Maxixe - $132 \mathrm{~m}$;

- área de soledade - $107 \mathrm{~m}$; 
- entre os rios Apodi-Mossoró e Upanema-do Carmo:

- área de Sombras Grandes - $100 \mathrm{~m}$.

- entre os rios Upanema-do Carmo e Piranhas-Açu:

- área Volta-Trapiä - $138 \mathrm{~m}$.

Na porção oriental da bacia a área de recarga se dispõe ni. tidamente nas proximidades ao contacto entre as formações Jan daỉra e Açu, de uma forma contínua, desde sudoeste de Jandaíra até norte de João Câmara, com os nūcleos de maior carga hidräu lica localizados nas seguintes áreas:

- entre os rios Mulungu e Tatu:

- ārea a sudoeste de Jandaíra - $203 \mathrm{~m}$ (carga hidrāulica máxị. ma do aquífero);

- área a sul de Queimadas - $179 \mathrm{~m}$.

- Para o interior, no extremo nordeste, a oeste da Lagoa do Boqueirão.

- área a leste de cruzamento - $77 \mathrm{~m}$.

Comparando-se o mapa piezométrico (MAPA 14) com o mapa pla ni-altimëtrico (MAPA 1) pode-se notar que as áreas preferen ciais de recarga se instalam em axeas topograficamente elevadas tais como as áreas da Serra de Mossorö, Maxixe, regiüo de Volta Trapiá e, na porção oriental da bacia, na chamada Serra verde.

Da observação conjunta agora do mapa piezométrico e do ma pa de frequências de descontinuidades (MAPA 9) nota-se estreita coin cidência entre as zonas preferenciais de recarga e as áreas de maior frequência de fraturamento, principalmente na porção oci dental da bacia. o mesmo é observado no mapa de densidade de descontinuidades (MAPA 10).

d) Diresões de Fluxo

Para a obtenção da geometria do fluxo subterrâneo no aqui fero Jandaira foram utilizados dados de poços cujas medidas de nỉvel d'ägua foram tomadas durante o mês de janeiro de 1980(IPT, 1982).

O mapa piezométrico elaborado (MAPA 14), revela uma tendên cia regional do fluxo subterrâneo de sul para norte, em direção ao oceano. Conforme jä havia sido observado por hidrogeólogos da SUDENE (REBOUÇAS et alii, 1967), secundariamente o filuxo se faz em direção aos vales aluvionares dos principais rios (rio 
Apodi-Mossoró, rio Upanema-do Carmo, rio Piranhas-Açu e rio Cą bugi-Mulungu-Amargoso). Esses vales, cuja influência diminui de oeste para leste, se constituem assim em verdadeiros drenos que aduzem as äguas subterrâneas até ao oceano. Essa configuração faz coincidir então os interflúvios com os divisores de āguas subterrâneas evidenciando-se como já exposto, a influência do rele vo sobre o padrão regional de fluxo. subtexrâneo. Para leste do rio Açu os escoamentos se fazem quase que unicamente para norte, diretamente para o mar. A ausência de vales importantes inibe o surgimento de divisores nitidos, sendo apenas levemente percep tível a influência do vale do rio Mulungu-Amargoso.

Da observação conjunta do mapa de drenagem superfícial (MA $P A$ 2) com o mapa de frequência de direções das descontinuidades (MAPA 6) pode-se notar que, com exceção da ärea situada a no roeste de Gov. Dix-Sept Rosado e da zona compreendida entre os rios Açu e Mulungu, a direção da drenagem superficial secundā ria é coincidente com a direção de major ereqtência das descoñ tinuidades, refletindo assim a influência destas no estabeleci mento das Iinhas de drenagem superficial e portanto na modela gem do relevo.

Comparando-se, por outro lado, o mapa piezométrico

(MAPA

14) com o mapa de freq̣thência de direções das descontinuidades (MAPA 6) pode-se notar que há tambēm uma coincidência genérica entre as direções de fluxo subterrâneo com as direções de maior frequência de descontinuidades, fazendo exceção a esse comporta mento, ainda a ärea situada a noroeste de Gov. Dix-sept Rosado e a região entre os rios Açu e Mulungu. A discoraância desta ũ tima região talvez seja devida à influência de intrusivas bāsi cas da Formação Macau, com corpos de direção geral SE-NW.

Pela observação ainda do mapa piezomētrico (MAPA 14), e dos mapas de direções mëdias (MAPA 7) e de comprimentos relati vos das descontinuidades (MAPA 8) pode-se verificar a mesma cor respondência geral entre as direções de fluxo subtexrâneo e as direções médias e direções de maiores comprimentos das desconti. nuidades, a exceção das mesmas āreas encontradas nas compara ções anteriores.

Fica notória dessa maneira, a estreita interrelação das descontinuidades e o comportamento do padrão de fluxo das águas 
subterrâneas e superficiais no âmbito de dominio dos calcáriós da Formação Jandaỉra.

Como se pode observar ainda pelo mapa piezométrico (MAPA 14), além do sentido preponderante do fluxo de sul para norte ou para os principais vales, interiorizando assim as äguas no dominio do aquífero, parte substancial do fluxo se dirige para oeste, em direção ao vale do rio Jaguaribe e para leste, em di reção à Lagoa do Boqueirão (região de Touros) e aos vales do rio Tatu e rio Maxaranguape (região de Pureza).

poucos e curtos feixes de linhas de fluxo porém se fazem para sul, em direção ao contacto entre as formações Jandaíra e Açu, tal como ocorre na parte ocidental e central da Bacia, que levam ãguas em direção às cabeceiras do riacho da Barra, a no roeste de Apodi; em direção às cabeceiras do riacho da Baixa Grande, a noroeste de Upanema e ainda em direção às cabeceiras do rio Palheiro e Lagoa do Piató, a noroeste de Açu. Esse. flu xo é responsável pela manutenção de pequenas fontes e exuda ções, muito frequentes na base da "cuesta" calcária nessaśs áreas.

\section{e) Gradientes Hidräulicos}

Os gradientes hidráulicos são relativamente mais variāveis nas porções ocidental e central da Bacia do que na porção orien tal. O valor máximo encontrado na porção ocidental è de $3,3 \mathrm{x}$ $10^{-2}$, observado no flanco norte do divisor de águas subterrâa neas que passa por Baraúnas, e que separa as águas que fluem di retamente para o oceano das que o fazem, indiretamente, através do vale do rio Mossoró. Na porção central, o maior gradiente é de $2,7 \times 10^{-2}$, observado no flanco oeste do divisor de águas subterrâneas que separa as àguas que fluem para o vale do rio do Carmo daquelas que o fazem para o vale do rio Açu.

Como exposto no item anterior, para leste do rio Açu as linhas de fluxo se dirigem diretamente para o oceano, nessas condições as equipotenciais são sensivelmente paralelas à costa. Aqui os gradientes se tornam mais regulares, sendo mais suaves entre os rios Açu e Mulungu, apresentando um valor máximo da or dem de $0,5 \times 10^{-2}$, tornando-se mais acentuados para leste, onde atingem o máximo de $7,7 \times 10^{-2}$ a sul da cidade de Jandaira. ES 
sa regularidade no paralelismo das equipotenciais e dos gradien tes hidráulicos é novamente alterada a nordeste da área, na ré gião de Cruzamento-Parazinho-Queimadas, por imposição do relevo, na denominada Serra dos Macacos (genericamente serra verde). Profundidades dos niveis d'ägua

A FIGURA 29 apresenta o histograma de frequência das pro fundidades dos níveis d'ägua nos poços tubulares no períodó $1979 / 1980$.

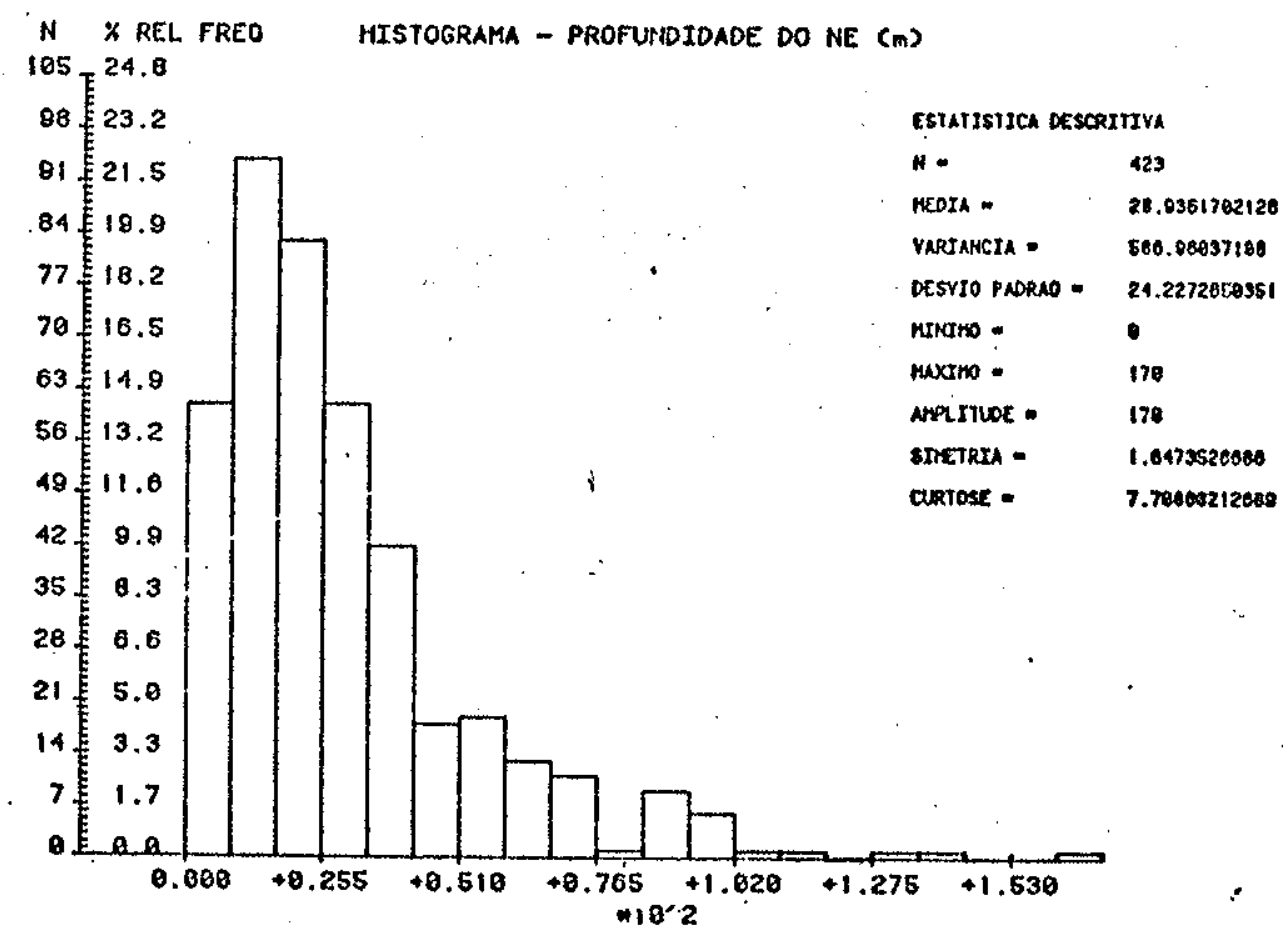

FIGURA 29 - Histograma de frequências de profundidades de niveis d'água estäticos nos poços.

Pode-se notar a grande variação das profundidades dos ni veis, onde $75 \%$ dos valores estão compreendidos entre 0,0 e $45 \mathrm{~m}$.

Refletindo as condições hidráulicas de aquífero livre, as profundidades dos niveis d'ägua estão em estreita relação com - relevo, onde os maiores valores são encontrados nas áreas pre ferenciais de recarga do aquifero: na região da Serra de Mosso ró, onde atinge $71 \mathrm{~m}$ no poço 897-282; região de Maxixe, com $40 \mathrm{~m}$ no poço 896-36; nas serras do Carmo e do Mel, onde atinge $170 \mathrm{~m}$ no poço 898-119 e na porção oriental da bacia, na região da ser ra da Macambira onde atinge $134 \mathrm{~m}$ no poço 899-14 e na serra dos Macacos, com $138 \mathrm{~m}$ no poço 900-9. 
Variação brusca a curta distância foi observada nás serras do Carmo e do Mel, de $90 \mathrm{~m}(3-4-75)$ no poço 898-120 (co ta 200) para $173 \mathrm{~m}(21-1-75)$ e $170 \mathrm{~m}(12-8-80)$ no poço 898-119 (cota $185 \mathrm{~m}$ ), distanciados de apenas $2,5 \mathrm{~km}$. timbora as medidas te nham sido tomadas em ëpocas diferentes, considerada no entanto a relativa regularidade dos terrenos, podem estar evidenciando a existência de aquíferos suspensos.

valores de profundidades do nível d'água observados por ocasião do cadastramento de poços "in situ" efetuado pelo IPT em março-abril/1979, quando comparados com os valores posterior mente medidos por ocasião da campanha de leituras de nivel d'āgua nos poços da rede piezométrica estabelecida, em janeiro/ 1980 (IPT, 1982) revelaram, para a maioria dos poços da rede, variações nulas ou redução de nĩvel até $3 \mathrm{~m}$. Houve porēm alguns pocos que apresentaram ascensão de nível, em média da ordem de $2 \mathrm{~m}$ e outros ainda redução de nível da mesma ordem de grandeza. Os resultados não são porém representativos devido ao grande in tervalo de tempo decorrido entre as medições. Considerando - se ainda que as chuvas na região geralmente se iniciam no mês de de zembro, pode-se admitir que durante as últimas medições os ní veis já estivessem influenciados pela recarga do aquífero.

\section{g) Eontes}

Em āreas bastante restritas, a superfície do nível d'ägua é interceptada pela superfície topográfica, dando origem às fon tes do aquífero Jandaira, tais como as representadas no MAPA 14. Essas fontes são mais frequentes a sudoeste da cidade de Jan daĩra, em ärea próxima à zona de recarga do aquífero, correspon dente às porções mais baixas nos entornos da serra verde, nas cabeceiras dos riabhos Olho d'ägua, da Mutuca, Tubibau e Baixa Branca (item 3.2).

Ainda no domínio dos calcārios, hä duas fontes pouco dis tantes entre si, localizadas no vale do riacho do Livramento, cerca de $15 \mathrm{~km}$ a sudeste de Gov. Dix-Sept Rosado. Outras fontes, embora estejam fora da ărea de afloramentos dos calcários Jan daira, têm sua origem ligada a este aquífero, surgindo na zona 
de contacto entre esses calcārios e as formações adjacentes. 'A mais importante delas é a Fonte de Pureza, localizada na cidade do mesmo nome, no extremo leste da Bacia, jā em área de cobertü ra dos calcários pelos sedimentos do Grupo Barreiras, que em área topograficamente deprimida exibem a fonte no topo dos cal cários, junto ao contacto entre essas litologias. Fluindo com vazão bastante expressiva medida em 21-11-1972 como da ordem de $648 \mathrm{~m}^{3} / \mathrm{h}$ (MANOEL FILHO, 1972), essa fonte garante, a partix daí, a perenidade do rio Maxaranguape. Suas āguas, que atualmente são utilizadas apenas para fins de recreação (balneário de pureza), poderão, mediante planejamento adequado, se revestir de grande importância no abastecimento de água potāvel daquela região, os resultados da anālise quỉica das águas da Fonte de pureza são apresentados nas TABEJAS 10 a 12 (ANEXO B).

No extremo oeste da Bacia, outra fonte bastante significa tiva é a denominada olho d'água da Bica, localizada à cerca de $20 \mathrm{~km}$ a sudeste de Tabuleiro do Norte, no Estado do Cearä, que se instala junto ao contacto dos calcārios Jandaira com os sedi mentos da Formação Açu.

Ainda como fonte de contacto, porém de menor expressão, te mos a ocorrente na fazenda Buraco da. Onça, localizada à cerca de $18 \mathrm{~km}$ ao sul de Gov. Dix-Sept Rosado. Essa fonte se instala junto à base da "cuesta" calcária, tambēm no contacto dos cal cá rios da Formação Jandaíxa com sedimentos da Formação Açu, na câ beceira de um dos afluentes da margem direita do riacho Livra mento anteriormente citado. 


\subsection{Interconexões Hidráulicas do Aquifero Jandaíra}

\section{5 .1 Introdução}

- aquífero Jandairra apresenta conexão hidráulica de signi ficativa importância com o aquîfero Açu a ele sotoposto, em to do o seu domínio, e de menor importância, com o sistema aquifero Dunas-Barreiras a ele sobreposto, na sua faixa mais próxima do litoral.

o funcionamento hidráulico do aquífero Jandaíra está esque maticamente representado na FIGURA 30 .

7.5.2 Interconexões hidräulicas entre os Aquíferos Jandaíra e Açu

Por comparação entre o mapa piezométrico do aquífero Jan daîra, livre, e do aquífero Açu, confinado, (IPT, 1982) foi possí vel executar o traçado da linha onde ocorre o equilibrio entre as cargas hidráulicas desses dois aquiferos (MAPA 14).

A análise do MAPA 14 permite notar que a oeste do rio Mu lungu, ou seja, na porção oeste e central da bacia, as cargas hidräulicas dos aquiferos Jandaíra e Açu, de maneira geral se equilibram nas vizinhanças da equipotencial de 30 metros, e que, para leste do rio Mulungu, a linha de equilíbrio desloca-se pa ra sul, situando-se agora nas vizinhanças da equipotencial de 65 metros. Esta região corresponde a uma área topograficamente elevada, genericamente denominada serra verde (item 3.1), onde os dois aquíferos apresentam cargas hidräulicas relativamente altas quando comparadas às cargas das āreas vizinhas.

Para sul da linha de equilibrio das cargas, o aquifero Jan daira apresenta cargas hidráulicas supexiores às do aquífero Açu e embora a camada semiconfinante da base do aquífero Jan daira seja relativamente espessa e pouco permeável (item 7.2), a extensa área a sul da linha de equilibrio - cerca de $7901 \mathrm{~km}^{2}$ è responsävel pela transferência de considerāvel volume de ăgua no sentido Jandaira - Açu, por drenança vertical descendente (item 7.7.3). Contraxiamente, na área a norte da linha de equi líbrio - $8.377 \mathrm{~km}^{2}$ - o aquífero Jandaíra apresenta cargas hí dxăulicas inferiores às do aquífero Açu e então o fenômeno de drenança se inverte, ocorrendo agora fluxo ascendente, no senti. 


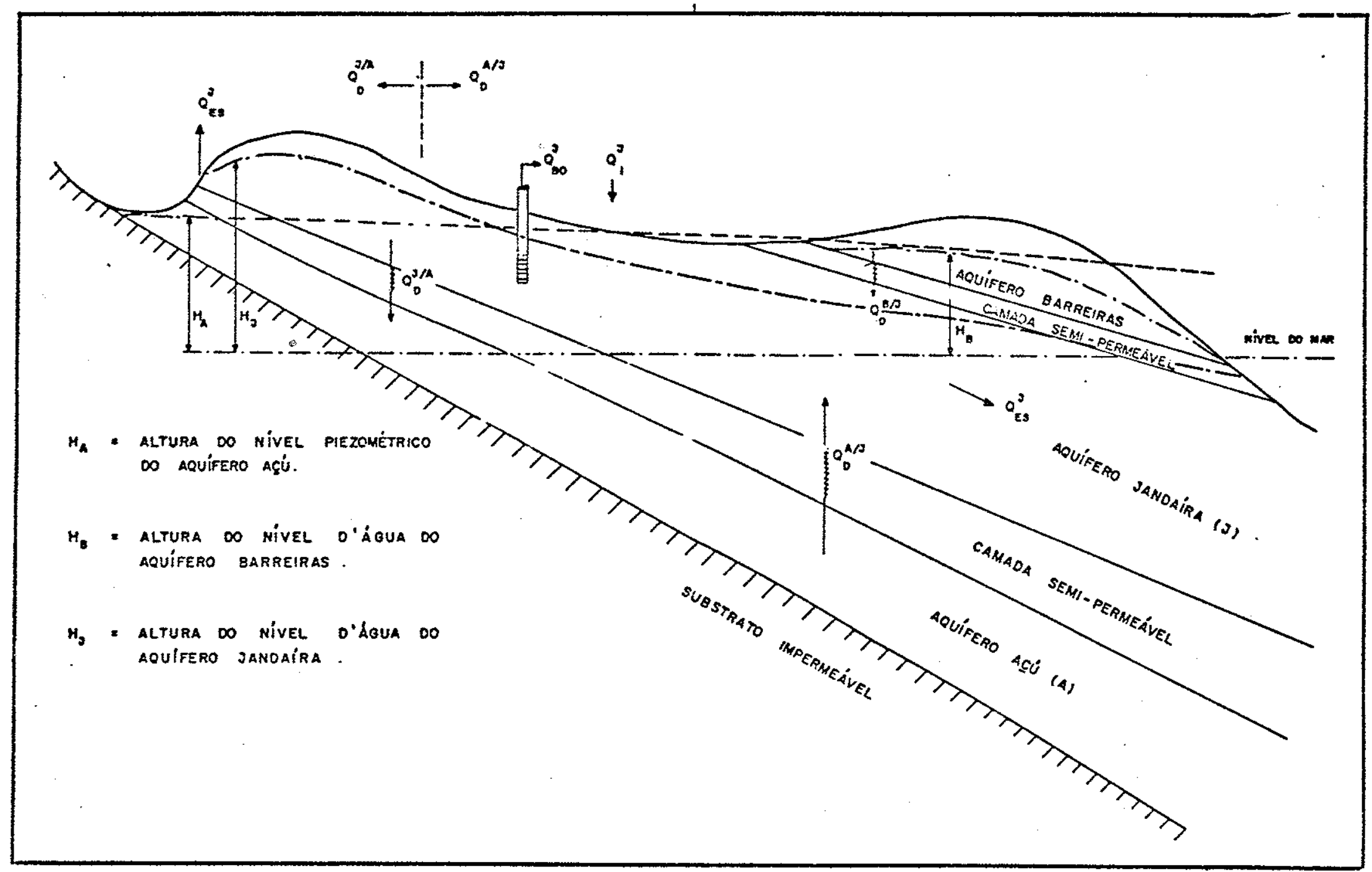

FIGURA 30 - Esquema do funcionamento hidräulico do aquífero Jandaira 
do Açu-Jandaỉra (item 7.7.5).

7.5.3 Interconexões hidrăulicas entre os aquiferos Jandaixa e Dunas-Barreiras

Observando-se ainda o mapa piezométrico do aquífero Jandaí ra (MAPA 14) pode-se notar que a equipotencial de $10 \mathrm{~m}$ se $\mathrm{s}$ i tua em uma posição bastante recuada para o interior em relação à orla atlântica. Nota-se também que, com exceção da área da Serra do Carmo e Serra do Mel e do extremo leste da área, os se dimentos do Grupo Barreiras estão localizados a norte dessa equi. potencial. A partir da análise conjunta do mapa piezométrico dó aquífero Jandaira (MAPA 14) e do mapa de cotas dos níveis d'água no sistema Dunas-Barreiras (MAPA 15); pôde-se delimitar as se guintes áreas onde as cargas hidráulicas do sistema aquífero Du nas-Barreiras são superiores às do aquífero Jandaíra: Icapuí (CF), Tibau (RN), serras do Carmo e do Mel (RN) e Serra do Man gue Seco-são Bento do Norte (RN).

Pode-se notar tambēm, a partir da observação desses mapas, que com exceção da área das serras do Mel e do Carmo, as dife renças de carga hidräulica entre os aquíferos é,em média, de cerca de $5 \mathrm{~m}$. Na ărea daquelas serras, os dados existentes, em bora sejam poucos, revelam grande amplitude piezométrica nos sé dimentos de cobertura, com cotas do nỉvel d'água variando desde 2 até $110 \mathrm{~m}$ em uma curta distância de $2,5 \mathrm{~km}$. Os perfis litoló gicos desses poços registram a existência de grande variação nas cotas do topo do calcário, (MAPA 11) levando a admitir a existên cia de aquiferos suspensos nessa ārea. Para efeito de cálculos porēm, admitiu-se como hipótese simplificadora neste trabalho, a continuidade do sistema aquifero Dunas-Barreiras também na área das serras do Carmo e do Mel, com as cargas hidráulicas des se sistema aquífero em média $5 \mathrm{~m}$ mais elevadas que as do aquífero Jandaíra. Nestas condições è mister admitir que nessas áreas haja transferência de ăguas do sistema aquifero Dunas-Bar reiras para o aquifero JandaIra, por drenança vertical descendente. 


\subsection{Posição da Interface Egua doce/salgada}

Na orla marinha da Bacia Potiguar as captações para abaste cimento nas maiores cidades são feitas no aquífero Açu e nos povoados, no sistema aquífero Dunas-Barreiras que apesar de ter limitação de produção, fornece ägua de boa qualidade e tem aten dido a demanda até o presente, além de ser de fäcil acesso, re legando-se o aquífero Jandaira a um plano secundärio. Não se tem informação, portanto, do comportamento real da interface āgua doce/salgada do aquífero Jandaíxa na zona litorânea sendo aqui feita apenas uma estimativa grosseira da sua profundidade.

Como base para os cálculos foi considerada a situação ocor rente no poço 899-169 na cidade de Galinhos, no litoral da porção central da bacia, com as caracteristicas apresentadas a seguir.

a) Perfiz litolögico

(Cota da boca: $\cong 5 \mathrm{~m}$ )

0-12 - areia fina, mal selecionada, com biodetritos;

12-27 - calcilutito creme esbranquiçado;

27-105 - areia amarela-clara, mal selecionada, muito argilosa, com intercalações de argilitos; níveis conglomeráti cos com seixos angulosos de quartzo, calcārio e argi Jisto.

105-117 - basalto vesicular, esverdeado, alterado;

117-487 - calcārio creme claro, maciço, dolomítico, duro, sub sidiariamente calcilutito branco a cinza esbranquiça do, duro;

487-765 - sedimentos da Formação Açu;

765 - rocha metamórfica.

b) observacões registradas durante a execugão do furo.

Prof.

Evento

$148 \mathrm{~m}$ - perda parcial de circulação;

$165 \mathrm{~m}$ - perda total de circulação;

$209 \mathrm{~m}$ - perda total de circulação;

$215 \mathrm{~m}$ - perda parcial de circulação e início de jorrância;

$230 \mathrm{~m}$ - perda de circulação;

$280 \mathrm{~m}$ - alta salinidade das águas de jorro, pois $\mathrm{CE}>20000 \mu \mathrm{mho} / \mathrm{cm}$ 
$361 \mathrm{~m}$ - vazões de jorxância de água salgada de $160 \mathrm{~m}^{3} / \mathrm{h}$ na maré baixa e de $210 \mathrm{~m}^{3} / \mathrm{h}$ na maré alta;

$580 \mathrm{~m}$ - diminuição da salinidade das äguas; $\mathrm{CE}=5000 \mu \mathrm{mho} / \mathrm{cm}$ (diluição pela mistura de água do aquífero $A c ̧ u)$

Como foram descritos basaltos alterados no intervalo 105117 m (Formação Macau), é provável que o aquífero Jandaíra este ja confinado, e portanto independente do sistema instalado nos sedimentos superiores (Formação Tibau (?), Grupo Barreiras (?)), aqui denominado sistema Dunas-Barreiras.

Admitindo-se os pressupostos de GHYBEN-HERZBERG, para que haja fluxo de áqua doce atravēs da seção de contacto entre o aquífero e o mar, é necessärio que nesse local a carga hidráulica

das suas äguas seja maior ou igual à carga hidrāulica re presentada pela coluna de água marinha, ou seja:

$$
\left(h_{d}+z\right) \cdot \gamma d>z \cdot \gamma s
$$

onde: $h_{d}$ - cota da ägua doce no ponto considerado, em relação ao nivel do mar:

z - profundidade da interface no ponto considerado, em relação ao nível do mar;

ra - peso específico da água doce $\left(1,000 \mathrm{gf} / \mathrm{cm}^{3}\right)$

Ys - peso específico da ăgua salgada (entre 1,020 até $1,030 \mathrm{gf} / \mathrm{cm}^{3}$ ).

A expressão anterior pode tambēm ser assim expressa:

$h_{d} \geqslant z \frac{(\gamma s-\gamma d)}{\gamma d}$, e tomando $\frac{\gamma s-\gamma d}{\gamma d}=\beta$, tem-se: $h_{d} \geqslant z \cdot \beta$

$B$ varia entre 0,020 e 0,030 , sendo 0,025 o valor mais frequente, e assim: $h_{d} \geqslant 0,025 \cdot z$

Como o poço en referência estä junto ao mar e a Formação Jandairra tem comportamento sub-horizontal, pode-se mesmo consi derar que a profundidade do topo da camada aquífera encontrada no poço, em relação ao nível do mar $(112 \mathrm{~m})$, seja a mesma pro 
fundidade, tambēm em relação ao nível do mar, no ponto de con tacto do seu topo com as ãguas do mar, e então:

$$
h_{d} \geqslant 0,025 \times 112 \mathrm{~m} \geqslant 2,8 \mathrm{~m} \text {. }
$$

Por outro lado, pela observação dos gradientes no mapa pie zométrico (MAPA 14) e notando que no poço mais próximo do mar na ärea considerada (poço 899-169) o nível piezométrico é de $5 \mathrm{~m}$, pode-se admitir, para o local considerado, uma carga hi drāulica de $3,5 \mathrm{~m}$. Nessas condições, a profundidade da interfa ce ägua doce/salgada nesse local será:

$$
z=h_{d} \div 0,025=3,5 \div 0,025=140 \mathrm{~m}
$$

Haverá portanto uma pequena seção de descarga do aquífero junto ao mar, de cerca de $28 \mathrm{~m}$.

As observações feitas durante a execução do furo do poço 899-169 parecem confirmar as estimativas, tanto pela jorráncia de água salgada que se iniciou a partir de cerca de $209 \mathrm{~m}$, como tambëm pelas freqtentes perdas de circulação de lama, numa fai xa de profundidadesque vai de 148 até cerca de $360 \mathrm{~m}$ denuncian do a existência de fendas e canais de circulação que teriam sị do desenvolvidos na zona de mistura das äguas do aquifero com as do mar, pelo aumento da agressividade das mesmas na zona de mistu ra (THRAILKIIL, 1968). 


\subsection{Balanco Hidrico do Aquífero Jandaíra}

\section{7 .1 Introdução}

o balanço hĩarico corresponde à aplicação do princípio da conservação da massa (ăgua) em um determinado sistema (aquífero), definida por algumas condições de contorno. Assim, num sistema com volume conhecido e durante um determinado período de tempo no qual se realiza o balanço, a diferença entre o volume total de āgua que entra (recarga) e o volume total de ägua que sai (descarga) do sistema deve ser igual à variação do volume de água de seu armazenamento.

o balanço hírico é portanto um recurso ütil por induzir a uma análise detalhada dos sistemas aquíferos, levando à obten ção da ordem de grandeza e importância relativa dos diferentes termos do balanço, permitindo assim o planejamento do uso racio nal do recurso. Não obstante, é preciso considerar que, dada a grande magnitude do sistema analisado e os tipos de variáveis envolvidas nas condições de contorno, as cifras que compõem o balanço não são exatas.

os medanismos de entrada e saída de águas no aquífero Jan daíra estão esquematizados na FIGURA 30, do item 7.5.1.

Admitindo-se que o aquifero Jandaira esteja em equilibrio hidrodinâmico ou seja, que durante um período de tempo bastante longo, não ocorram variações regionais do nível piezométrico, a menos das variações sazonais, então a vazão de escoamento anual médio é igual à alimentação anual média, e assim pode-se expressar esse equilibrio atravës da seguinte igualdade:

$$
Q_{I}+Q_{D}^{A / J}+Q_{D}^{B / J}=Q_{E S}+Q_{D}^{J / A}+Q_{B O}
$$

onde temos:

19 Membro: Entradas (Recarga)

Q - volume anual de ägua que aporta no aquifero por infiltra ção das ãguas meteöricas atravēs da superficie de exposí ção do mesmo (infiltração eficaz);

$\Omega_{D}^{A / J}$ - volume anual de ägua transferida do aquifero Açu para o aquifero Jandaira por drenança vertical ascendente; e 
$Q_{D}^{B / J}$ - volume anual de água transferida do sistema aquífero Du nas-Barreiras para o aquífero Jandaíra, por drenança ver tical descendente;

20 Membro: Saídas (Descarga)

$Q_{E S}$ - volume anual de ägua que se escoa através das frentes na turais de descarga do aquífero;

$Q_{D}^{J / A}$ - volume anual de āgua transferida do aquífero Jandaíra para o aquífero Açu, por drenança vertical descendente; $e$

$\mathrm{Q}_{\mathrm{BO}}$ - volume anual de água explotada do aquifexo por bombeamen to através de poços.

- cálculo dos volumes correspondentes a cada uma das par celas da descarga e da recarga de água no aquífero são apresen tados nos itens que se seguem.

\section{7 .2 Descarga pelos exutórios naturais do aquífero ( $Q_{\mathrm{ES}}$ )}

Analisando-se os escoamentos naturais no aquífero Jan daĩra a partir do mapa piezométrico (MAPA 14) pôde-se identifi car as seguintes frentes de descarga:

- a norte - em direção à costa atlântica-norte da bacia;

- a oeste - em direção ao vale do rio Jaguaribe;

- a sul - em direção à zona de afloramento do aquífero Açu, tẹn do-se aqui considerado as seguintes áreas:

- cabeceiras do riacho da Barra (noroeste de Apodi);

- cabeceiras do riacho Baixa Grande (noroeste de Upanema);

- cabeceiras do rio Palheiro (região da Lagoa do Piató, a no roeste de $A c ̧ u$ ).

- a leste - em dixeção à àrea de dominância do aquífero Barreiras, onde se distinguem dois ramos:

- em direção à Lagoa do Boqueirão (região de Touros)

- em direção aos vales dos rios Tatu e Maxaranguape (região de pureza). 
As vazões de escoamento natural do aquífero Jandairra junto a esses exutórios foram calculadas através da equação:

$$
\mathrm{Q}=\mathrm{T} \cdot \mathrm{i} \cdot \mathrm{I}, \text { onde: }
$$

$Q=$ vazão de escoamento natural $\left(\mathrm{m}^{3} \% \mathrm{a}\right) ;$

$\mathrm{T}=\operatorname{transmissividade}\left(\mathrm{m}^{2} / \mathrm{h}\right) ;$

$i$ = gradiente hidráulico da superfície piezométrica (adimensio nal);

1 = largura da frente de escoamento na seção considerada (km).

Para a execução dos cãlculos foram levantados os gradien tes hidráulicos (i) e as larguras dasfrentes de escoamento a partir do mapa piezométrico (MAPA 14). As transmissividades mē dias (T) para cada seção, foram obtidas a partir do mapa de va zão especifica ( $Q / \mathrm{s}$ ) (MAPA 13), atravēs da relação entre ambas, conforme exposto no item 7.3. As vazões de descarga estimadas nas diferentes fxentes são apresentadas na TABELA 6 a seguir.

TABELA 6 - Volumes anuais de água escoada pelos exutörios naturais do aquífero Jandaira.

Exutōrios

Vazão de descarga $\left(Q_{\mathrm{ES}}\right)$

$$
\left(x 10^{6} \mathrm{~m}^{3} / \mathrm{a}\right)
$$

Costa atlântica norte .......... 42,632

Rio Jaguaribe $\ldots \ldots \ldots \ldots \ldots \ldots \ldots \ldots .2,308$

Riacho da Barra ............ 1,983

Riacho Baixa Grande ............ 0,056

Rio Palheiro ............. 0,412

Lagoa do Boqueirão ........... 2,835

Rio Maxaranguape $\ldots \ldots \ldots \ldots \ldots \ldots$ 2,164

TOTAL $\ldots \ldots \ldots \ldots \ldots \ldots$

7.7.3 Descarga por Drenança para o aquífero $A c ̧ u\left(Q_{D}^{J / A}\right)$

Desprezando-se o armazenamento que pode ocorrer na camada semipermeável da base do aquífero Jandaíra e considerando-se que 
as superfícies piezométricas dos aquíferos Jandaỉra e Açu repre sentam um estágio, em regime estacionārio, dos dois sistemas, po de-se calcular o volume de água que no período de um ano atra vessa a camada semiconfinante nos dois sentidos.

Com esse objetivo foram determinadas as diferenças médias de carga hidrāulica entre os dois aquíferos, e as espessuras mé dias da camada semiconfinante (IPT, 1982) em pequenos setores da área on de ocorre o fenômeno de drenança vertical descendente ou ascen dente. o călculo em cada setor foi efetuado através da equação de Darcy, assim expressa:

$$
Q_{D}=K^{\prime} \times \sum_{j=1}^{n} \frac{\Delta \bar{h}_{j} \times a_{j}}{\bar{b}_{j}^{\prime}}
$$

onde:

$Q_{D}-$ vazão de drenança $\left(m^{3} / h\right)$;

$\mathrm{K}^{\prime}$ - condutividade hidräulica vertical da camada semi-confinan te $(\mathrm{m} / \mathrm{h})$;

$\Delta \bar{h}_{j}$ - diferença média de cargas hidráulicas no setor j conside rado $(\mathrm{m})$;

$a_{j}$ - area do setor $j\left(m^{2}\right), e$

$\bar{b}_{j}^{\prime}$ - espessura média da camada semi-confinante no setor $j$ (m)

Para facilitar o cálculo dos volumes transferidos anualmen te do aquífero Jandaira para o aquífero Açu por drenança verti cal descendente, a área em que as cargas hidráulicas do aquífero Jandaira são superiores às do aquífero Açu foi subdividida em seis setores. Pela aplicação da lei de Darcy em cada um desses setores e adotando-se $\mathrm{K}=4,2 \times 10^{-7} \mathrm{~m} / \mathrm{h}$ (item 7.2 ) foram cal culadas as vazões de drenança $Q_{D}^{\mathrm{J} / \mathrm{A}}$ apresentadas na TABELA 7 da pägina seguinte.

7.7.4 Descarga por explotacão através de bombeamento de poços $\left(\mathrm{Q}_{\mathrm{BO}}\right)$

- volume total explotado apenas por poços tubulares que captam água no aquífero Jandaíra, durante o ano de 1979, foi de $3,6 \times 10^{6} \mathrm{~m}^{3} / \mathrm{a}$ (item 9.6), tendo-se adotado então este valor pa ra efeito de cälculos no balanço hídrico do aquífero ou seja: 


$$
Q_{B O}=3,6 \times 10^{6} \mathrm{~m}^{3} / \mathrm{a}
$$

TABELA 7 - Volumes anuais de água drenada do aquífero Jandaíra para o aquifero Acu.

\begin{tabular}{lcccc}
\hline SETORES & $\begin{array}{c}\text { Superf. } \\
\left(\mathrm{km}^{2}\right)\end{array}$ & $\begin{array}{c}\bar{b}^{\prime} \\
(\mathrm{m})\end{array}$ & $\begin{array}{c}\Delta \overline{\mathrm{h}} \\
(\mathrm{m})\end{array}$ & $\begin{array}{c}\mathrm{Q}_{\mathrm{D}}^{\mathrm{J} / \mathrm{A}} \\
\left(\mathrm{x} 10^{6} \mathrm{~m}^{3} / \mathrm{a}\right)\end{array}$ \\
\hline 1 - a oeste de $37^{\circ} 00^{\prime}$ & 5515 & 300 & 37,1 & 2,509 \\
2 - entre $37^{\circ} 00^{\prime}-36^{\circ} 30^{\prime}$ & 716 & 150 & 18,7 & 0,328 \\
3 - entre $36^{\circ} 30^{\prime}-36^{\circ} 00^{\prime}$ & 828 & 100 & 32,1 & 0,977 \\
4 - entre $36^{\circ} 00^{\prime}-35^{\circ} 30^{\prime}$ & 684 & 100 & 25,2 & 0,634 \\
5 - entre Parazinho e Lagoa & & & & \\
$\quad \begin{array}{l}\text { do Boque irão } \\
\text { TOTAL }\end{array}$ & 126 & 200 & 19,2 & 0,044 \\
\hline
\end{tabular}

7.7.5 Recarga por drenaņ̧a do aquífero Açu para o aquífero Jandaira $\left(Q_{D} A / J\right)$

Semelhantemente ao caso tratado no item 7.7.3, a área onde as cargas hidräulicas do aquífero Açu são superiores às do aquí fero Jandaira foi subdividida em cinco setores. Da mesma forma tambëm foram calculadas as vazões de drenança apresentadas na TABELA 8 a seguir.

TABELA 8 -Volumes anuais de ãgua drenada do Aquifero Açu para - aquífero Jandaíra.

\begin{tabular}{|c|c|c|c|c|}
\hline SETORES & $\underset{\left(\mathrm{km}^{2}\right)}{\text { Superf }}$ & $\begin{array}{l}\overline{\bar{b}^{\prime}} \\
(\mathrm{m})\end{array}$ & $\begin{array}{l}\Delta \bar{h} \\
(\mathrm{~m})\end{array}$ & $\begin{array}{l}Q_{D}^{A / J} \\
\left(x \perp 0^{6} \mathrm{~m}^{3} / \mathrm{a}\right)\end{array}$ \\
\hline 1 - a oeste de $37^{\circ} 00^{\prime}$ & 3190 & 500 & 18,5 & 0,434 \\
\hline 2 - entre $37^{\circ} 00^{\prime}$ e $36^{\circ} 30^{\prime}$ & 1.429 & 550 & 15,5 & 0,148 \\
\hline 3 - entre $36^{\circ} 30^{\prime}$ e $36^{\circ} 00^{\prime}$ & 1370 & 350 & 27,8 & 0,400 \\
\hline 4 - entre $36^{\circ} 00^{\prime}$ e $35^{\circ} 30^{\prime}$ & 954 & 300 & 24,4 & 0,285 \\
\hline $\begin{array}{l}5 \text { - faixa costeira (além da } \\
\text { equipotencial 10m do aquí } \\
\text { fero Jandaira! }\end{array}$ & 1434 & 650 & 15,0 & 0,122 \\
\hline TOTAL, & & & & 1,389 \\
\hline
\end{tabular}


7.7.6 Recarga por arenança do sistema aquifero Dunas-Barreiras para o aquífero Jandaíra $\left(Q_{D}^{\mathrm{B} / \mathrm{J}}\right)$

o cálculo do volume de água transferido anualmente do sis tema aquifero Dunas-Barreiras para o aquífero Jandaíra foi féi to com base nos elementos geométricos e hidráulicos anteriormen te citados (itens 7.2 e 7.5.3), admitindo-se armazenamento nulo na camada semiconfinante do topo do aquífero Jandaíra, aplican do-se a equação de Darcy.

As espessuras da camada semiconfinante como visto, variam de 6 até $52 \mathrm{~m}$ tendo-se admitido, para efeito de cálculo, uma es pessura mëdia da ordem de $15 \mathrm{~m}$. Devido às pequenas espessuras dos sedimentos de cobertura, considerou-se aqui apenas parte de sua área de domínio como constituindo o sistema aquífero DunasBarreiras onde foi possivel identificar as äreas relacionadas no item 7.5 .3 com cargas hidräulicas superiores às. do aquífero Jan daira. Dessa maneira foi estimada a vazão de drenança do siste ma aquífero Dunas-Barreiras para o aquifero Jandaira, conside rando-se os seguintes valores

$$
\mathrm{K}^{\prime}=0,4 \cdot 10^{-6} \mathrm{~m} / \mathrm{h} ; \Delta \overline{\mathrm{h}}=5 \mathrm{~m} ; \overline{\mathrm{b}}^{\prime}=15 \mathrm{~m} \text { e } \mathrm{A}=2033 \mathrm{~km}^{2}
$$

A substituição dos valores acima na equação de Darcy forne ce: $Q_{\mathrm{D}}^{\mathrm{B} / \mathrm{J}}=2,49 \times 10^{6} \mathrm{~m}^{3} / \mathrm{a}$. A contribuição de cada ärea é ainda apresentada na TABELA 9 a seguir:

TABELA 9 - Volumes anuais de ägua drenada do sistema aquífero Du nas-Barreiras para o aquífero Jandaíra

\begin{tabular}{lcccc}
\hline AREAS & $\begin{array}{c}\text { Superf. } \\
\left(\mathrm{km}^{2}\right)\end{array}$ & $\begin{array}{c}\overline{\mathrm{b}}^{\prime} \\
(\mathrm{m})\end{array}$ & $\begin{array}{c}\Delta \overline{\mathrm{h}} \\
(\mathrm{m})\end{array}$ & $\begin{array}{c}\mathrm{Q}_{\mathrm{D}}^{\mathrm{B} / \mathrm{J}} \\
\left(\times 10^{3} \mathrm{~m}^{3} / \mathrm{a}\right)\end{array}$ \\
\hline $\begin{array}{c}\text { Icapuí (CE) } \\
\text { Tibau (RN) }\end{array}$ & 278 & 15 & 5 & 0,341 \\
$\begin{array}{c}\text { Serras do Mel e do Carmo } \\
\text { (RN) }\end{array}$ & 300 & 15 & 5 & 0,368 \\
$\begin{array}{c}\text { Mangue seco - São Bento } \\
\text { do Norte (RN) }\end{array}$ & 696 & 15 & 5 & 0,854 \\
\hline & 756 & 15 & 5 & 0,927 \\
\hline TOTAL & & & 2,49 \\
\hline
\end{tabular}




\subsubsection{Recarga através da infiltração de äguas pluviais (Q.)}

A superfície de domínio dos calcäxios aflorantes da Forma ção Jandaỉra, correspondente portanto à ärea atravēs da qual se processa a infiltração direta das äguas de chuva, tem aproxima damente $10298 \mathrm{~km}^{2}$ (item 7.1).

A pluviometria média anual incidente sobre a ārea foi ava liada admitindo-se, três subäreas, dependentemente dos interva los de precipitação mëdia anual (item 4.2). Considerando-se a superfície de abrangência de cada subárea de exposição passível de infiltração e a pluviometria média anual em cada uma delas, foi calculado o volume anual de āgua de chuva precipitada em ca da uma dessas āreas e apresentados no QUADRO 11 a seguir.

\begin{tabular}{|c|c|c|c|c|}
\hline Subăreas & Dominio & $\begin{array}{l}\text { Superfície } \\
\qquad\left(\mathrm{km}^{2}\right)\end{array}$ & $\begin{array}{l}\text { Pluviometria } \\
\text { anual média } \\
\text { (mm/a) }\end{array}$ & $\begin{array}{c}\text { Volume } \\
\text { anual. médio } \\
(Q p) \\
\left(x 10^{6} \mathrm{~m}^{3} / \mathrm{a}\right)\end{array}$ \\
\hline Deste & Rio Jaguaribe até Hipólito & 5689 & 650 & 3698 \\
\hline Central & Hipólito atē Jandaíra & 2912 & 525 & 1529 \\
\hline Leste & Jandaĩra até a costa leste & 1697 & 725 & 1230 \\
\hline \multicolumn{4}{|c|}{ TOTAL } & 6457 \\
\hline
\end{tabular}

QUADRO 11- Pluviometria anual mëdia na ärea de exposição dos calcários Jandaira.

Considerando o equilibrio anteriormente aventado (item 7.7.1) o volume médio anual de àguas pluviais que aportam no aquífero Jandaira, ou seja, a infiltração eficaz, pode ser então estima da atravēs do balanço hĩdrico, considerando-se os volumes conhe cidos de entrada e de saída do mesmo, ou seja:

$$
Q_{I}=Q_{E S}+Q_{D}^{J / A}+Q_{B O}-\left(Q_{D}^{A / J}+Q_{D}^{B / J}\right)
$$

Assim sendo: $Q_{I}=56,6 \times 10^{6} \mathrm{~m}^{3} / \mathrm{a}$

Portanto a taxa de infiltração eficaz no aquífero Jandaí ra $\left(I_{e}\right)$ em termos porcentuais será:

$$
I_{e}=\frac{\Omega_{I}}{\Omega p}=\frac{56,6 \times 10^{6} \mathrm{~m}^{3} / \mathrm{a}}{6457 \times 10^{6} \mathrm{~m}^{3} / \mathrm{a}}=0,009, \text { logo } \mathrm{I}_{\mathrm{e}}(z)=0,98
$$




\subsection{Avaliação das reservas do aquífero Jandaíra}

7.8.1 Introdução

A avaliação quantitativa bem como a qualitativa das reser vas de água do aquífero Jandaira se revestem de extrema impor tância por permitir a estimativa dos recursos hídricos disponí veis e assim nortear os princípios de planejamento do aprovei tamento dos recursos hidricos subterxâneos: O aspecto quantita tivo das águas armazenadas no aquífero são a seguir analisados, calculando-se as reservas permanentes e reguladoras, bem como o as pecto da renovação das reservas do aquífero; aspectos qualitati vos serão apresentados no item 8 .

\subsubsection{Reservas permanentes e reservas reguladoras}

a) Reservas permanentes (Rp)

As reservas permanentes são definidas como sendo o volume de água armazenado nos terrenos, abaixo da superficie minima de variação periódica dos níveis d'água, susceptível de ser resti tuỉdo por gravidade (água de saturação), em aquífero livre, acrescido do volume de água acumulado sob pressão, quando con finado:

Para a estimativa das reservas permanentes do aquifero Jan daíra foram consideradas as suas caracteristicas dimensionais e hidrodinâmicas, apresentadas nos itens 7.1 e 7.3 . Na falta de dados que permitissem calcular a porosidade eficaz do aquífero, admitiu-se para efeito de cálculo, o mesmo valor apresentado por TODD (1965) para litologias semelhantes e adotado por MANOEL FILHO (1971), ou seja: $\mu=5 \times 10^{-2}$

Considerando-se a inexistência de valores de coeficiente de armazenamento do aquífero Jandaira em sua parte semiconfinada pelos sedimentos de cobertura, a sua relativa pequena área de semiconfinamento e ainda que a parcela de āgua armazenada sob pressão, no caso dos aquíferos confinados è muito reduzida quan do comparada ao volume de água de saturação do aquífero quando livre, para a estimativa das reservas permanentes considerou-se - aquífero Jandaíra como sendo livre em toda a sua extensão.

Assim sendo, o volume das suas reservas ë dado pela expres. são: 


$$
R_{p}=A \cdot h \cdot \mu \text { onde: }
$$

$\mathrm{R}_{\mathrm{p}}=$ reserva permanente, $\left(\mathrm{m}^{3}\right)$;

$A=$ ärea da superfúcie livre das äguas no aquífero: $16278 \mathrm{~km}^{2}$

$\mathrm{h}=$ espessura mëdia saturada: $150 \mathrm{~m}$;

$\mu=$ porosidade eficaz: adotada como sendo $5 \times 10^{-2}$, e então: $R_{p}=16.278 \mathrm{~km}^{2} \times 150 \mathrm{~m} \times 0,05=122,085 \times 10^{9} \mathrm{~m}^{3}$, ou seja: $R_{p}=122 \times 10^{9} \mathrm{~m}^{3}$

b) Reservas reguzadoras $\left(R_{p}\right)$

As reservas reguladoras, tambëm denominadas reservas perió dicas, correspondem ao volume de águas armazenado no aquífero na porção compreendida entre as duas posições extremas, máxima e mínima, da superfície dos níveis d'ägua do aquífero no decox rer de um ciclo hidrolögico. São portanto correspondentes ao vo lume de água restituido para o meio físico exterior ao sistema aquifero através dos escoamentos junto aos seus exutórios natu rais no decorrer do período considerado.

Em condições de equilibrio as reservas reguladoras corres pondem portanto à infiltração eficaz no aquífero e então:

$$
R_{r}=56,6 \times 10^{6} \mathrm{~m}^{3} / \mathrm{a}
$$

\subsubsection{Renovação das reservas do aquífero Jandaíra}

Constantemente as reservas em água subterrânea de um siste ma aquífero se renovam, compensando as perdas do sistema, tanto pelo aporte direto de äguas pluviais de infiltração, como pelo aporte indireto, através da transferência de āgua, por drenança, a partix de outros aquiferos adjacentes.

o volume de äguas de renovação, quando se considera o aquí fero em equilíbrio hidrodinâmico, é igual ao volume de escoamen to subterrâneo médio junto aos seus exutörios naturais (e por tanto iguais às reservas periödicas médias ou ainda iguais à in filtração eficaz média). 
a) Coeficiente de realimentagão ( $C_{p}$ )

o coeficiente de realimentação de um aquifero expressa a parcela das suas reservas que é anualmente renovada, sendo por tanto calculado através da relação entre a reserva reguladora média (ou o volume do escoamento subterrāneo médio ou ainda o volume de infiltração eficaz mëdio) e as reservas totais $\left(R_{t}\right)$, que corresponde à soma das reservas permanente e periódica. As sim:

$$
C_{x}=\frac{R_{x}}{R_{t}}=\frac{56,6 \times 10^{6} \mathrm{~m}^{3} / \mathrm{a}}{122,141 \times 10^{9} \mathrm{~m}^{3}}=0,00046 \cong 5 \times 10^{-4 / a}
$$

então: $C_{r}(\%) \cong 0,05 \%$ ao ano.

b) Tempo de renovagão $\left(t_{r}\right)$

E o tempo que seria necessārio para substituir a reserva total se ela fosse totalmente esgotada, considerando-se a reno vação atravēs do volume anualmente aportado ao aquífero. Em um aquifero em equilíbrio é portanto a relação entre a reserva to tal e o volume anual de infiltração eficaz (ou volume anual de escoamento subterrâneo junto aos exutóriós naturais).

$$
t_{x}=\frac{122,141 \times 10^{9} \mathrm{~m}^{3}}{56,6 \times 10^{6} \mathrm{~m}^{3} / \mathrm{a}}=2158 \mathrm{a}
$$

\subsubsection{Recursos explotáveis do aquífero Jandaîra}

Alēm do aspecto quantitativo das reservas, na avaliação dos recursos hidricos subterrâneos disponíveis deve-se analisar também os aspectos de qualidade das äguas armazenadas e das téc nicas de explotação, além dos aspectos econômicos relativos aos custos de captação e legais no que diz respeito ao direito às águas. Abordaremos aqui apenas os aspectos quantitativos, aspec tos qualitativos das āguas subterrâneas do aquífero Jandaíra se rão apresentados no item 8 , e algumas considerações referentes às tëcnicas e custos de captação são ainda apresentados nos itens 9 e 10, respectivamente.

$\mathrm{Na}$ avaliação dos recursos explotáveis de um aquífero admi te-se um estado de equilíbrio hidrăulico entre as vazões de en trada e de saída do sistema, e considerando-se o ciclo hidroló 
gico com sua parcela de recarga do aquífero, estará implícito que as águas subterrâneas constituem um recurso renovāvel. A de terminação quantitativa desses recursos è complexa, uma vez que a explotação excessiva das águas de um aquífero provoca tambëm resposta de aquíferos que estejam hidraulicamente a ele relacio nados, até que um novo estado de equilíbrio seja atingido, o que pode alterar sensivelmente as condições de recarga e descar ga nos seus exutórios naturais. Assim sendo, somente uma dete $\underline{x}$ minada quantidade de āgua subterrânea poderá ser explotada sem provocar perturbações indesejāveis nos sistemas aquíferos. Es se volume anual de água teoricamente explotável sem alterar a reserva permanente seria portanto correspondente à vazão anual média de escoamento natural nas frentes de descarga do aquífero (reserva reguladora ou infiltração eficaz).

Com base nos valores das reservas reguladoras e suas flu tuações, nas reservas permanentes, nos dados técnicos e econômicos de projetos de captação e ainda nos dados de qualidade da āgua, torna-se possivel então avaliar os recursos explotáveis de um aquífero.

Devemos considerar, por outro lado, que a extração de ägua de um aquífero qualquer provoca um aprofundamento da superfície de suas äguas e, consequentemente, aumento dos gradientes hi dráulicos. Tal rebaixamento induzirá, por conseguinte, maiores taxas de recarga e por este motivo se admite atualmente que se possa explotar, com critērios, alëm das reservas reguladoras, sem provocar esgotamento das reservas aquifexas. Deve-se consi derar no entanto que estes recursos podem variar no espaço e no tempo em função das condições hidrogeolögicas, dos efeitos das explotações sobre o regime de fluxo, da concepção e disposi ção das obras de captação, dos equipamentos para explotação, etc.

Do exposto depreende-se que a explotação dos recursos hi dxicos de um determinado aquifero deveră ser acompanhada por es tudos hidrogeológicos para controle criterioso da evolução do comportamento dos mesmos, a par das técnicas de análise de sis temas que permitam a avaliação sistemática de todos os conjun tos intervenientes no aproveitamento racional das reservas.

No caso do aquífero Jandaira, admitindo-se que as suas re servas possam ser utilizadas para quaisquer usos e que as técni 
cas de captação permitam sempre o acesso a essas reservas, o vo lume anual teoricamente explotävel sem alterar as reservas perma nentesseria portanto correspondente ao volume anual médio da in filtração eficaz, ou seja: $56,6 \times 10^{6} \mathrm{~m}^{3} / \mathrm{a}$. Deve-se considerar que, estando o aquífero Jandaíra em conexão hidrāulica com o aquífero Açu e sendo este atualmente muito solicitado, é previ sível uma alteração no comportamento das suas cargas hidráuli cas que provocará variações nos volumes de drenança em ambos os sentidos. Assim sendo, e levando-se em conta as oscilações freqtentes nos volumes de recarga, circunstancialmente, como me dida de segurança, adotando-se $75 \%$ daquele valor, teríamos:

$$
\mathrm{R}_{\exp \mathrm{l}}=43 \times 10^{6} \mathrm{~m}^{3} / \mathrm{a}
$$

Nota-se assim que o volume atualmente explotado $\left(3,6 \times 10^{6}\right.$ $\mathrm{m}^{3} / \mathrm{a}$, em 1979 ) representa somente $8,4 \%$ dos recursos explotäveis, como acima estimado. 


\section{HJDROQUIMICA DO AQUIFERO JANDAIRA}

\subsection{Introdução}

Os principais objetivos dos estudos hidroquímicos estabele cidos nesta monografia hidrogeolögica foram a caracterização hí droquímica atual das águas do aquífero Jandaíra no que diz res peito aos teores médios dos constituintes químicos e valores mé dios dos parâmetros físico-químicos; conhecimento sobre a evo lução da composição química da ăgua subterrânea em seu movimen to dentro do aquifero e a avaliação da adequação das suas águas para os diferentes usos básicos: doméstico, agrícola e indus trial.

Para esses estudos foram utilizados essencialmente os da dos de anälise físico-químicas de águas de poços tubulares con tidos nos seguintes documentos:

- Inventário Hidrogeológico Bäsico do Nordeste. Folha 10: Jagua ribe-NE. SUDENE, Hidrogeologia, 30 (MANOEL FILHO, 1971).

- Plano diretor dos recursos de solo e água no Vale do Apodi, Rio Grande do Norte. Relatörio Final (DNOCS, 1978).

- Estudo hidrogeológico regional detalhado do Estado do Rio Gran de do Norte (IPT, 1982).

Alëm dessas fontes, foram ainda levantados, diretamente jun to à Companhia de Desenvolvimento de Recursos Minerais do Rio Grande do Norte - $C D M / R N$, laudos de anälises químicas de äguas do aquífero. Jandaira, referentes ao periodo 1981/82.

Embora todos esses trabalhos apresentassem muitos dados de anălise de ăgua, grande parte delas não pôde ser aqui utilizada, principalmente pela dificuldade de correspondência entre os po f̧os constantes dos inventārios executados por essas entidades, devido às diferenças de informações registradas ou mesmo ausên cia de informes que poderiam permitir uma correspondência segu ra. Assim sendo, para evitar eventuais erros, no caso de corres pondências duvidosas as anälises não foram utilizadas. Foram re cusadas ainda anălises incompletas e tambēm anälises sobre as 
quais persistiam dúvidas quanto ao aquífero captado. Foram uti lizadas 242 anälises conforme consta no QUADRO 12 a seguir. cujos dados são apresentados nas TABELAS 10 a 15 do ANEXO $B$.

\begin{tabular}{|c|c|c|}
\hline Fonte & Tipo de Captação & $\begin{array}{l}\text { Quant.de } \\
\text { amostras }\end{array}$ \\
\hline $\begin{array}{l}\text { Manoel Filho (1971) } \\
\text { (SUDENE) }\end{array}$ & Poços tubulares & 1 \\
\hline $\begin{array}{l}\text { DNOCS/Hidroservice } \\
(1978)\end{array}$ & Poços tubulares & 43 \\
\hline \multirow[t]{3}{*}{ IPT/SIC-RN (1982) } & Poços tubulares & 150 \\
\hline & Fontes & 02 \\
\hline & Água de chuva & 03 \\
\hline CDM/RN (Cad.Compl.) & Poços tubulares & 43 \\
\hline & TOTAL & 242 \\
\hline
\end{tabular}

QUADRO 12 - Origem das amostras de ägua.

Para esta monografia foi utilizada a identificação de po ços segundo o inventário do IPT por corresponder ao levantamen to mais recente e para facilitar o acesso às informações. A TA BELA 17, (ANEXO B), fornece a correlação entre os poços cadastra dos pelas entidades referidas e que tiveram a anälise de āgua incluída nesta monografia.

Apōs a seleção, os dados das análises químicas de āgua fo ram tratados por tēcnicas matemäticas e gráficas visando à cạ racterização hidroquímica do aquífero Jandaíra. Os resultados constantes nos laudos das anälises foram inicialmente submeti dos a um programa de computador a fim de que fosse verificada a consistência dos dados. O critério bāsico utilizado se fundamen tou na avaliação dos erros das análises atravēs do mētodo do bạ lanço iônico, tendo-se adotado os limites constantes : em LOGAN (1965) para a aceitação de erros em anälises. Nos casos em que os resultados dessas anälises apresentavam erro excessivo de ba lanço, estas foram utilizadas somente apōs criteriosa avaliação do parâmetro de interesse, relativamente às outras amostras.

Foram elaborados diagramas, grä́ficos e mapas hidroquímicos, que através da sua interpretação, juntamente com as caracterís 
ticas geológicas e hidráulicas do aquífero, forneceram subsí dios à elaboração de hipōtese de seu funcionamento hidräulico no que concerne às zonas de recarga e descarga naturais, inter conexões hidráulicas, etc., tendo porēm como maior objetivo, a caracterização hidroquímica das águas e a sua adequação aos dî. ferentes usos.

\subsection{Caracterizacão hidroquímica do aquífero Jandaíra}

Com o objetivo de melhor caracterizar as āguas do aquífero Jandaira em seus aspectos químicos e físico-químicos, possibili tar a análise de seu comportamento hidrogeoquímico e ainda de constatar eventuais anomalias com os teores dos constituintes químicos e valores das propriedades físico-químicas analisadas, foram obtidos parâmetros estatísticos, tendo sido tambēm elabo rados diversos histogramas e anālises de regressão.

\section{a) Parâmetros estatisticos}

o programa de computador aplicado proporcionou a determina ção de parâmetros estatísticos băsicos impressos no final de ca da relação de dados, apresentados nas TABELAS 10 a 1.3, ANEXO B.

A sintese desses dados é apresentada na TABELA 18 a seguir. Para efeito de comparação foram colocados tambēm os valores en contrados em amostras de águas de chuva coletadas em três ciậ des do Estado do Rio Grande do Norte: Natal, no litoral leste, Pau dos Ferros, no extremo sudoeste, e Mossoró, tambēm na por ção oeste, porēm à cerca de $40 \mathrm{~km}$ da costa.

Para a determinação dos teores:limites foi utilizado inter valo de confiança em 95\%, calculado segundo a equação:

Intervalo de Conf. $=\bar{x} \pm z_{\alpha / 2} \frac{s}{\sqrt{n}}$, onde:

$\overline{\mathrm{x}}=$ mëdia das amostras;

$\mathbf{z}_{\alpha / 2}=$ valor dado pela tabela de distribuigão normal para 95 용 de confiança;

s - desvio padrão da amostra e

n - número de observações.

Baseados então nos dados estatísticos apresentados, pode- 
TABELA 18 - Composição química média das ãguas do aquífero Jandaira, comparativamente às äguas de chuvas.

\begin{tabular}{|c|c|c|c|c|c|c|c|c|c|c|c|}
\hline \multirow[t]{2}{*}{ PAPRYTIROS CCRSIDEFAOOS } & \multicolumn{8}{|c|}{ ievins tes pores } & \multicolumn{3}{|c|}{ FGUAS RE CHUVAS } \\
\hline & $\begin{array}{c}\text { Cos } 0 E \\
\end{array}$ & $m a{ }^{2}$ & wrow; & 510 & $\begin{array}{l}\text { OESUIO } \\
\text { BASPFO }\end{array}$ & $\begin{array}{l}\text { BHTER } \\
\text { FIAYC }\end{array}$ & YALO & DE ces: & $\begin{array}{l}\text { PAL DOS } \\
\text { FERROS }\end{array}$ & MOSSCRO & NATAL \\
\hline p: & 233 & 6.50 & 8.90 & 7.95 & 0.40 & 7.17 & - & 8.73 & 5,3 & 5,5 & 6,0 \\
\hline Concutividzfe elëtrica ( $\mu \mathrm{mo} / \mathrm{cm})$ & 238 & 405.40 & 17013.03 & 2639.59 & 2356,60 & 0.0 & -7 & 308.53 & 2,4 & 6,8 & $5 ; 8$ \\
\hline$=i \leq D(\pi g / l)$ & 239 & 270.27 & 11342.00 & 1793.05 & 1571.07 & 0.0 & -4 & 372.36 & - & - & - \\
\hline Direza total (mg/1 de $\mathrm{CaCO}_{3}$ ) & 239 & 85.00 & 6196.90 & 989.13 & 875.89 & 0.0 & -2 & 705.87 & 0,35 & 0,49 & 4,75 \\
\hline Alcatinidzes total $\left(\mathrm{mg} / 1\right.$ ce $\left.\mathrm{CaCO}_{3}\right)$ & 239 & 16.96 & 720.00 & 267.23 & 101.80 & 67.58 & - & 466.74 & $4,6 i$ & 5,13 & 2,53 \\
\hline Södio $\left(\mathrm{mg} / 1\right.$ de $\left.\mathrm{ia}^{+1}\right)$ & 239 & 19.20 & 3060.30 & 248.33 & 326.90 & 0.0 & - & 889.05 & 0,20 & 0.40 & 4.65 \\
\hline Potässio $\left(\pi: g / 1\right.$ de $\left.\mathrm{K}^{+1}\right)$ & 239 & 0.91 & 124.00 & 15.18 & 16.00 & 0.0 & - & 46.54 & 0.10 & 0.05 & 0.96 \\
\hline Cểeio $(m g /)$ do $\left(\mathrm{a}^{+\hat{\varepsilon}}\right)$ & 239 & 7.00 & 1315.20 & 190.97 & 185.55 & 0.0 & - & 562.84 & 0,12 & 0,01 & $0,0=$ \\
\hline Magrés:o $\left(\mathrm{mg} / 1\right.$ de $\left.\mathrm{Kg}^{+2}\right)$ & 239 & i..o. & 708.51 & 121.54 & 110.26 & 0.0 & - & 337.65 & 0,01 & 0,11 & 0,58 \\
\hline Forro total $(\mathrm{mg} / 1$ de $\mathrm{Fe})$ & 160 & 0.00 & 3.20 & 0.32 & 0.55 & 0.0 & - & 1.40 & nihil & nihil & 0,05 \\
\hline Fivoreto $\left(\mathrm{mg} / \mathrm{i}\right.$ de $\left.\mathrm{F}^{-1}\right)$ & 98 & 0.00 & 3.80 & 0.47 & 0.54 & 0.0 & - & 1.72 & - & - & - \\
\hline Cioreto $\left(n g / 1\right.$ de $\left.\mathrm{Ci}^{-1}\right)$ & 239 & 27.87 & 7043.40 & 72.14 & 963.30 & 0.0 & & 600.21 & $<0,01$ & $<0,01$ & 8,98 \\
\hline Sulfato $\left(m g / 1\right.$ de $\left.\mathrm{so}_{4}^{-2}\right)$ & 226 & 2.11 & 2032.40 & 250.79 & 372.83 & $\cdot 0.0$ & - & $\$ 81.54$ & nihil & nihil & 3,07 \\
\hline Bicarbcneto $\left(-\mathrm{G} / 1\right.$ de $\left.\mathrm{HCO}_{3}^{-1}\right)$ & 239 & 20.59 & 873.40 & 305.29 & 122.30 & 65,58 & - & 545.00 & 5,63 & 6,25 & 3,05 \\
\hline Cerbonato $\left(\mathrm{mg} / 1\right.$ de $\left.\mathrm{CO}_{3}{ }^{-2}\right)$ & 238 & $? .70$ & $37.8 \varepsilon$ & 9.83 & 14.45 & 0.5 & - & 33,15 & zero & zero & - \\
\hline Nitrato $\left(n g / 1\right.$ de $\left.\mathrm{NO}_{3}^{-1}\right)$ & $2 ! 9$ & +.30 & 730.29 & 32.49 & 71.24 & ก.o & - & 172.12 & - & - & 1,48 \\
\hline $\mathrm{Co}_{2}$ disscivito $\left(\mathrm{mg} / \mathrm{de} \mathrm{CO}_{2}\right\}$ & 239 & 0.37 & 75.65 & 8.68 & 11.26 & 0.0 & - & 30.71 & 44,79 & $3 i, 45$ & 4,90 \\
\hline
\end{tabular}


- se considerar, como aceitäveis para as águas do aquífero Jandaíra, os valores constantes da coluna "Intervalo de confiança", da TABELA 18, os quais poderão ser tomados como padrão para efeito de considerações a respeito da caracterização e compara ções das ăguas do aquĩfero Jandaíra. Assim alterações que pro movam desvios do valor padrão deverão ser criteriosamente anali sadas.

Para efeito de comparações são apresentados no QUADRO 13, parâmetros relativos aos aquíferos Açu e Barreiras que têm cone xão hidráulica com o aquífero Jandaỉra e ainda das āguas subter râneas das rochas cristalinas (item 7.5 ).

\begin{tabular}{|c|c|c|c|c|}
\hline \multirow{2}{*}{$\begin{array}{c}\text { Propriedades } \\
\text { e } \\
\text { Constituintes }\end{array}$} & \multicolumn{4}{|c|}{ Aquíferos } \\
\hline & Jandaixa & Açu & Barrejras & Cristalino \\
\hline pHs & 7,95 & 7,9 & 6,87 & 7,8 \\
\hline $\mathrm{CE}$ & 2689,5 & 1398,7 & 172,99 & 6,314 \\
\hline TSD & 1793,06 & 932,4 & 115,33 & 4606,7 \\
\hline $\begin{array}{l}\text { Dureza Total (mg/1 } \\
\left.\mathrm{CaCO}_{3}\right)\end{array}$ & 989,1 & 323,3 & 43,20 & 1712,9 \\
\hline $\begin{array}{l}\text { Alc. Total (mg/1 } \\
\left.\mathrm{CaCO}_{3}\right)\end{array}$ & 267.21 & 166,2 & 41,53 & 297,9 \\
\hline $\mathrm{Na}\left(\mathrm{mg} / 2 \mathrm{Na}^{+1}\right)$ & 248,3 & 154,6 & 18,72 & 808,2 \\
\hline$K\left(m g / 2 K^{+1}\right)$ & 15,1 & 16,7 & 4,33 & 50,2 \\
\hline$M g\left(\mathrm{mg} / \mathrm{L} \mathrm{Mg}^{+2}\right)$ & 121,5 & 33,1 & 5,19 & 287,2 \\
\hline $\mathrm{Ca}\left(\mathrm{mg} / 1 \mathrm{Ca}^{+2}\right)$ & 198,9 & 74,9 & 8,76 & 217,6 \\
\hline Fe total $(\mathrm{mg} / \mathrm{l} \mathrm{Fe})$ & 0.32 & 0.4 & 0,39 & 2,84 \\
\hline$F\left(m g / 2 F^{-1}\right)$ & 0.47 & - & 0,04 & - \\
\hline CI $\left(m g / 1 \mathrm{Cl}^{-1}\right)$ & 712,14 & 288,2 & 25,87 & 2146,5 \\
\hline $\mathrm{SO}_{4}^{-2}\left(\mathrm{mg} / 1 \mathrm{SO}_{4}^{-2}\right)$ & 250,79 & 72,6 & 6,64 & 142,5 \\
\hline $\begin{array}{lll}\mathrm{HCO}_{3} & (\mathrm{mg} / \mathrm{l} & \mathrm{HCO}_{3} \\
\mathrm{CO}_{3}^{-2} & (\mathrm{mg} / 1 & \left.\mathrm{CO}_{3}^{-2}\right)\end{array}$ & $\begin{array}{r}306,29 \\
9,83\end{array}$ & $\begin{array}{c}232,2 \\
7\end{array}$ & $\begin{array}{r}50,36 \\
0,64\end{array}$ & $\begin{array}{r}335,5 \\
13,7\end{array}$ \\
\hline $\mathrm{NO}_{3}^{-1}\left(\mathrm{mg} / 2 \mathrm{NO}_{3}^{3-1}\right)$ & 32,49 & 19,2 & 6,61 & $\begin{array}{l}13,1 \\
21,2\end{array}$ \\
\hline $\mathrm{CO}_{2}\left(\mathrm{mg} / \mathrm{d} \mathrm{CO}_{2}\right)$ & 8.7 & 8,0 & 18,21 & 9,9 \\
\hline
\end{tabular}

OUADRO 13 - Teores médios de constituintes químicos das āguas dos aquíferos Jandaíra, Açu, Barreiras e Cristalino no Es tado do Rio Grande do Norte (Fonte: IPT, 1982).

Adotando-se aqueles valores-padrão para o aquífero Jandaí ra foi elaborada a TABELA 19 que apresenta a relação dos poços anômalos em relação a cada constituinte químico e paxâmetro fí sico-quimico analisado.

Pode-se notar que excetuando-se $0 \mathrm{pH}$, a maior frequência de amostras anômalas é encontrada para os fluoretos $(10,2 \%)$, e a menor para os nitratos $(4,1 \%)$. A partir dos dados da TABELA 19 foi elaborado ainda o QUADRO 14 que apresenta a frequência de parâmetros anônalos nas ăguas dos poços. Nota-se assim que das 239 amostras analisadas, 80 delas $(33,48)$ apresentam pelo menos um caräter anômalo dentre os pesquisados, a maioria 
TABELA 19 - Poços anômalos em relação ao intervalo de confiança em $95 \%$

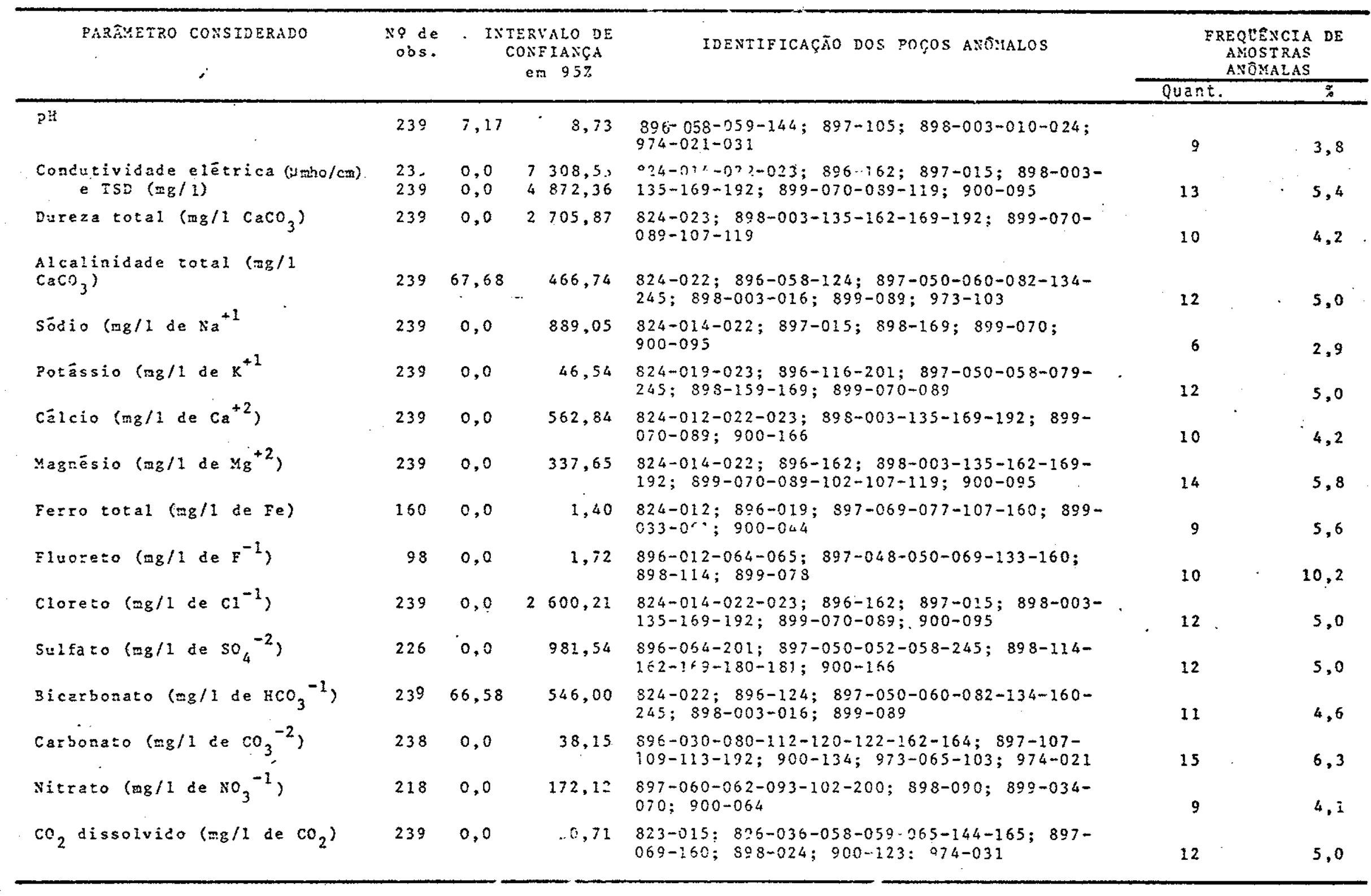


QUADRO 14 - Frequência de anomalias dos parämetros físicos e químicos nas āguas dos poços

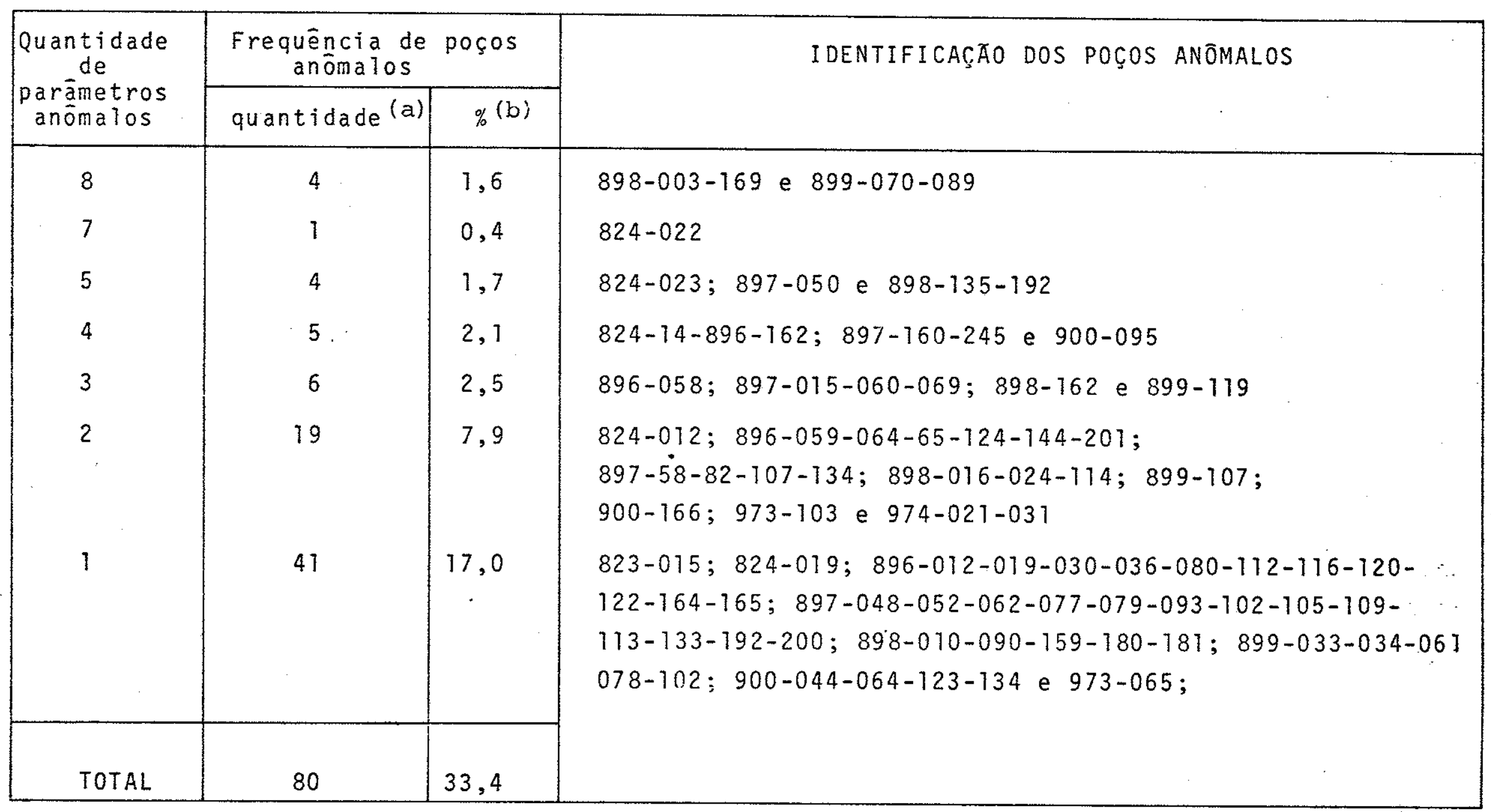

(a) Intervalo de confiança em 95\%

(b) Em relação aos 239 poços analisados. 
(178) porém apresentando somente um caráter anômalo. Nota-se ainda que 4 poços $(1,6 \%$ apresentam 8 parâmetros anômalos, ou seja, a metade dos parâmetros analisados se revelaram anômalos.

A explicação das prováveis causas das anomalias são apre sentadas em itens que se seguem, quando são analisados e inter pretados os diagramas e mapas hidroquimicos.

\section{b) Histogramas de freqllência}

Com o objetivo de verificar o comportamento da distribui ção dos parâmetros analisados foram construidos os histogramas de freqtência (FIGURA 31 de a até $q$ ) nos quais estão indicados os 1 i mites de potabiliadade: pH, Condutividade elétrica, dureza total, Alc. total e parcial, cátions $\left(\mathrm{Na}^{+1}, \mathrm{~K}^{+1}, \mathrm{Mg}^{+2}, \mathrm{Ca}^{+2}\right.$ e $\mathrm{Fe}$ total) e ânions $\left(\mathrm{F}^{-1}, \mathrm{Cl}^{-1}, \mathrm{SO}_{4}^{-2}, \mathrm{HCO}_{3}^{-1}, \mathrm{CO}_{3}^{-2} \mathrm{e} \mathrm{NO}_{3}^{-1}\right)$, e TSD.

Pode-se observar que com exceção dos bicarbonatos $\left(\mathrm{HCO}_{3}^{-1}\right.$ ) todos os constituintes apresentam uma distribuição assimētrica das frequências dos seus teores, e de uma maneira geral decres centes com o aumento dos mesmos. No relativo aos parâmetros fí sico-químicos nota-se que o pli tem distribuição aproximadamente simétrica ao redor do valor 7,8 e a alcalinidade total, grosse ramente simétrica em relaçäo ao valor $274 \mathrm{mg} / 1$ de $\mathrm{CaCO}_{3}$ equiva lente, ao passo que a alcalinidade parcial, a condutividade elé trica e a Dureza total são assimétricas, com frequência decres centes com o aumento dos seus valores.

com base nos histogramas foram estabelecidos os teores má ximos dos constituintes quimicos e valores dos parâmetros fís co-químicos para $75 \%$ das amostras, que são apresentados no QUA DRO 15 a seguir.

c) Anälise de regressão

Com o objetivo de avaliar o nível de dependência e encon trar, atravēs da equaçăo de melhor ajuste a relação de dependên cia entre alguns parâmetros e ions preponderantes, foram feitas também as análises de regressão apresentadas nos itens que se seguem.

Como a condutividade elétrica indica o teor salino das áquas e sendo este de grande interesse para o estudo do aquí fero Jandaira, foram feitas vārias anälises envolvendo esse pa râmetro. 


\begin{tabular}{|c|c|}
\hline Parâmetros considexados & $\begin{array}{l}\text { Teor mâximo } \\
\text { para } 75 \% \text { das amostras }\end{array}$ \\
\hline $\mathrm{pH}$ & 8,20 \\
\hline $\mathrm{CE}(\mu \mathrm{mho} / \mathrm{cm})$ & 3700,00 \\
\hline $\operatorname{TSD}(\mathrm{mg} / \mathrm{l})$ & 2500,00 \\
\hline Dureza total $\left(\mathrm{mg} / 1\right.$ de $\left.\mathrm{CaCO}_{3}\right)$ & 1300,00 \\
\hline Alcalinidade parcial (mg/l de $\mathrm{CaCO}_{3}$ ) & 1,22 \\
\hline Alcalinidade total ( $\mathrm{mg} / 1$ de $\mathrm{CaCO}_{3}$ ) & 345,00 \\
\hline Sódio $\left(\mathrm{mg} / 1\right.$ de $\left.\mathrm{Na}^{+1}\right)$ & 3,20 \\
\hline Potássio (mg/l de $\mathrm{K}^{+1}$ ) & 21,00 \\
\hline Cálcio (mg/l de $\mathrm{Ca}^{+2}$ ) & 270,00 \\
\hline Magnësio (mg/l de $\mathrm{Mg}^{+2}$ ) & 150,00 \\
\hline Ferro total (mg/l de $\mathrm{Fe})$ & 0,30 \\
\hline Fluoreto (mg/l de $F^{-1}$ ) & 0,50 \\
\hline Cloreto (mg/l de $\mathrm{Cl}^{-1}$ ) & 500,00 \\
\hline Sulfato (mg/l de $\left.\mathrm{So}_{4}^{-2}\right)$ & 270,00 \\
\hline Bicarbonato (mg/l de $\mathrm{HCO}_{3}^{-1}$ ) & 360,00 \\
\hline Carbonato (mg/l de $\mathrm{CO}_{3}^{-2}$ ) & 1170,00 \\
\hline Nitrato $\left(\mathrm{mg} / 1\right.$ de $\left.\mathrm{NO}_{3}^{-1}\right)$ & 48,00 \\
\hline
\end{tabular}

QUADRO 15 - Teores mäximos dos constituintes químicos para 75\% das amostras. 


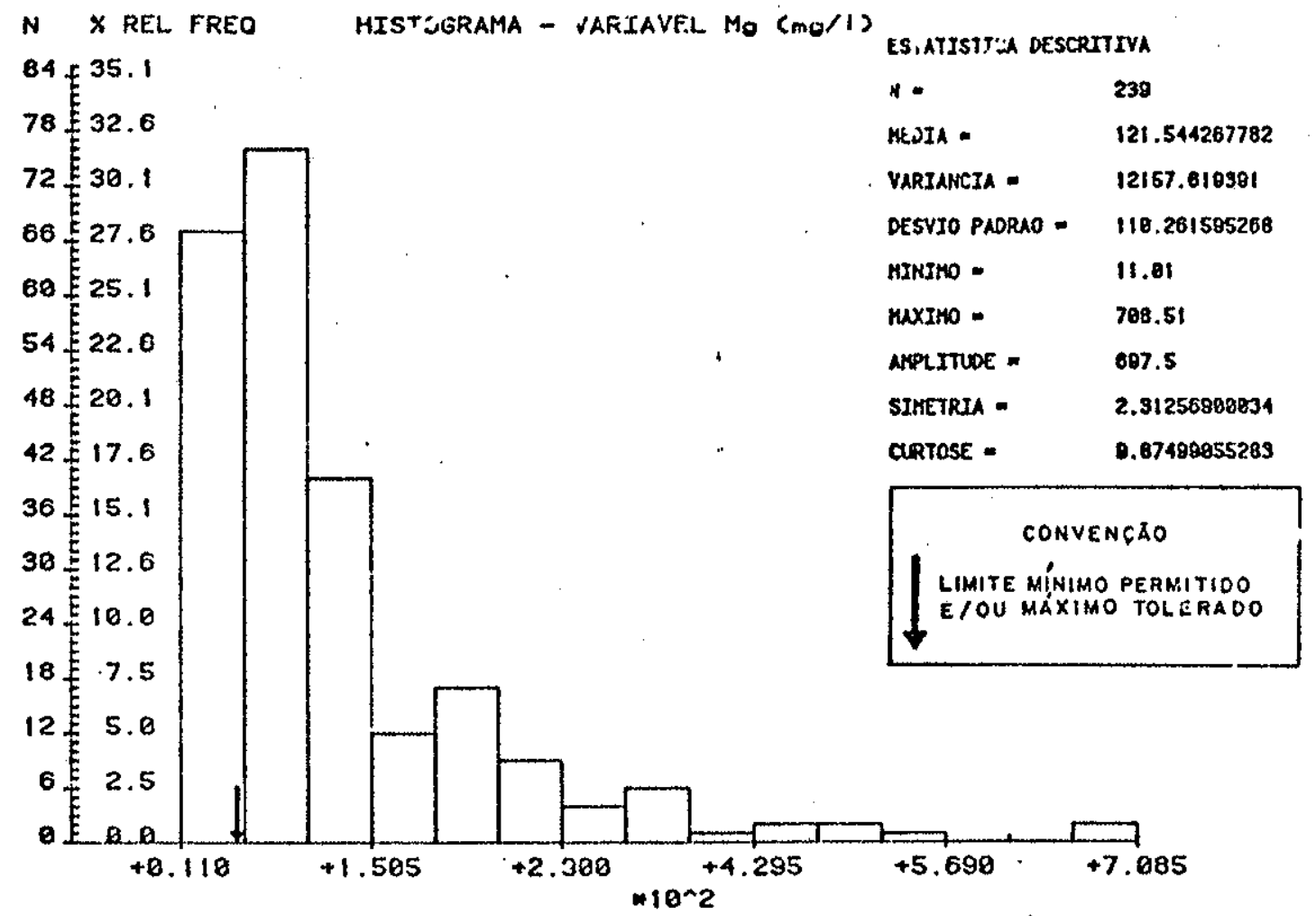

FIGURA 31 a - Frequência dos teores de Magnésio (mg/l $\mathrm{Mg}^{+2}$ )

N \% REL FREO HISTOGRAMA - VARIAVEL Ca $(m g / 1)$

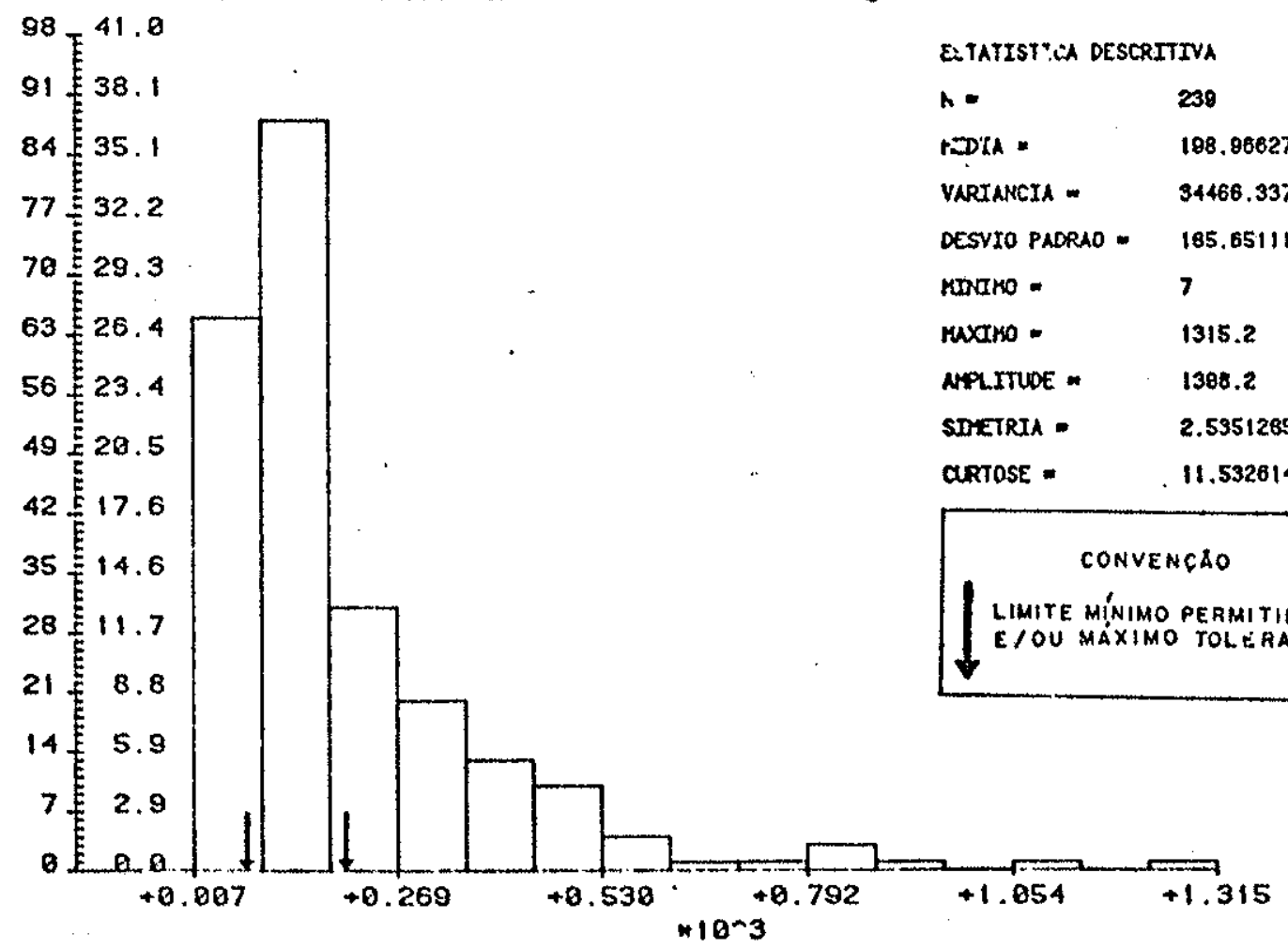

FIGURA $31 \mathrm{~b}$ - Frequência dos teores de cálcio (mg/1 $\mathrm{Ca}^{+2}$ ) 


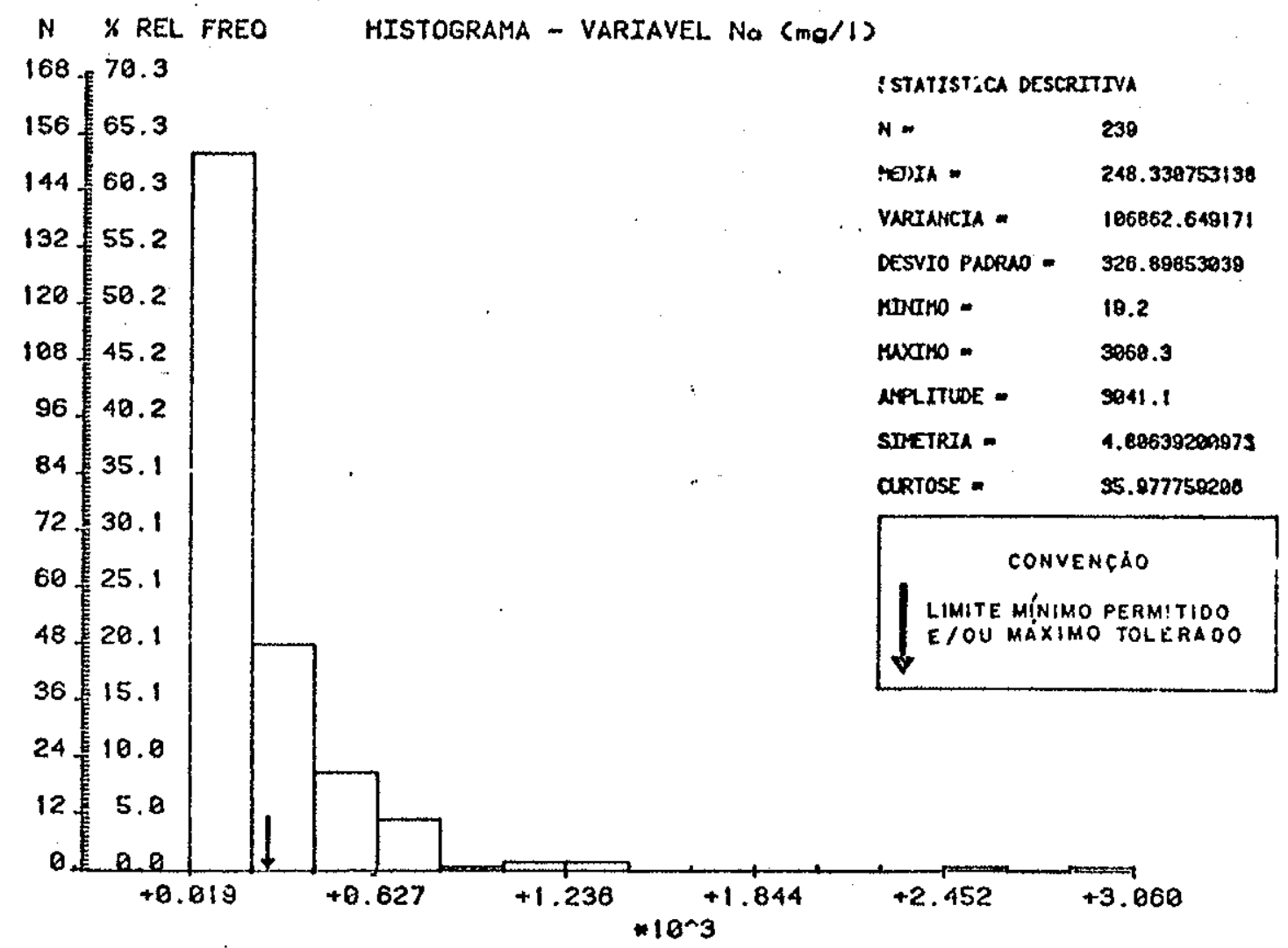

FIGURA 31.c - Frequência dos teores de sódio (ma/l. $\mathrm{Na}^{+1}$ )

$N$ * REL FREO HISTOGRAMA - VARIAVEL $K(\mathrm{mo} / \mathrm{l})$

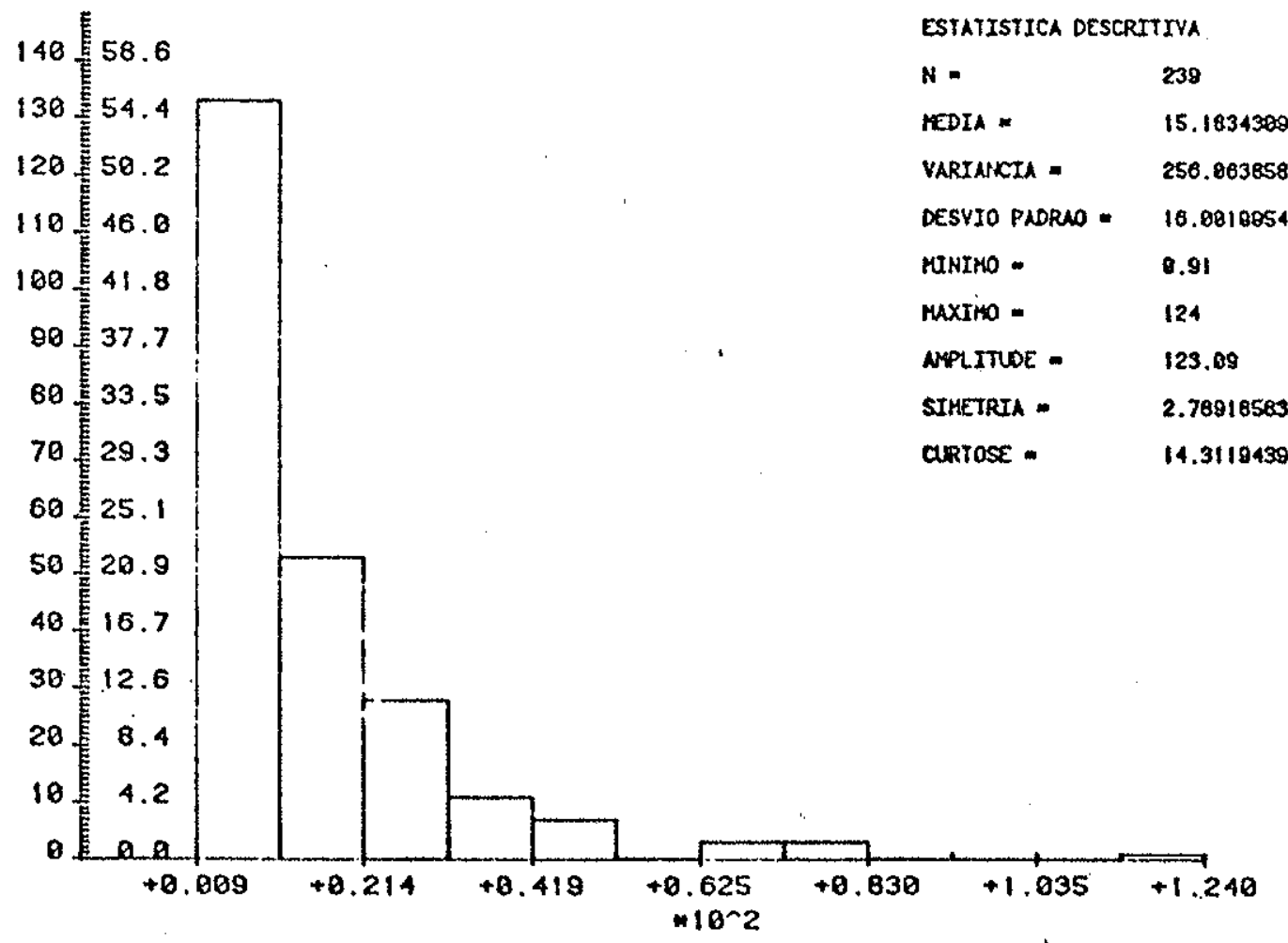

FIGURA 31d - Frequência dos teores de Potässio $\left(m g / 1 \mathrm{~K}^{+1}\right.$ ) 
N $*$ REL FREO hISTOGRAMA - VARIAVEL F - total $(\mathrm{mg} / 1)$

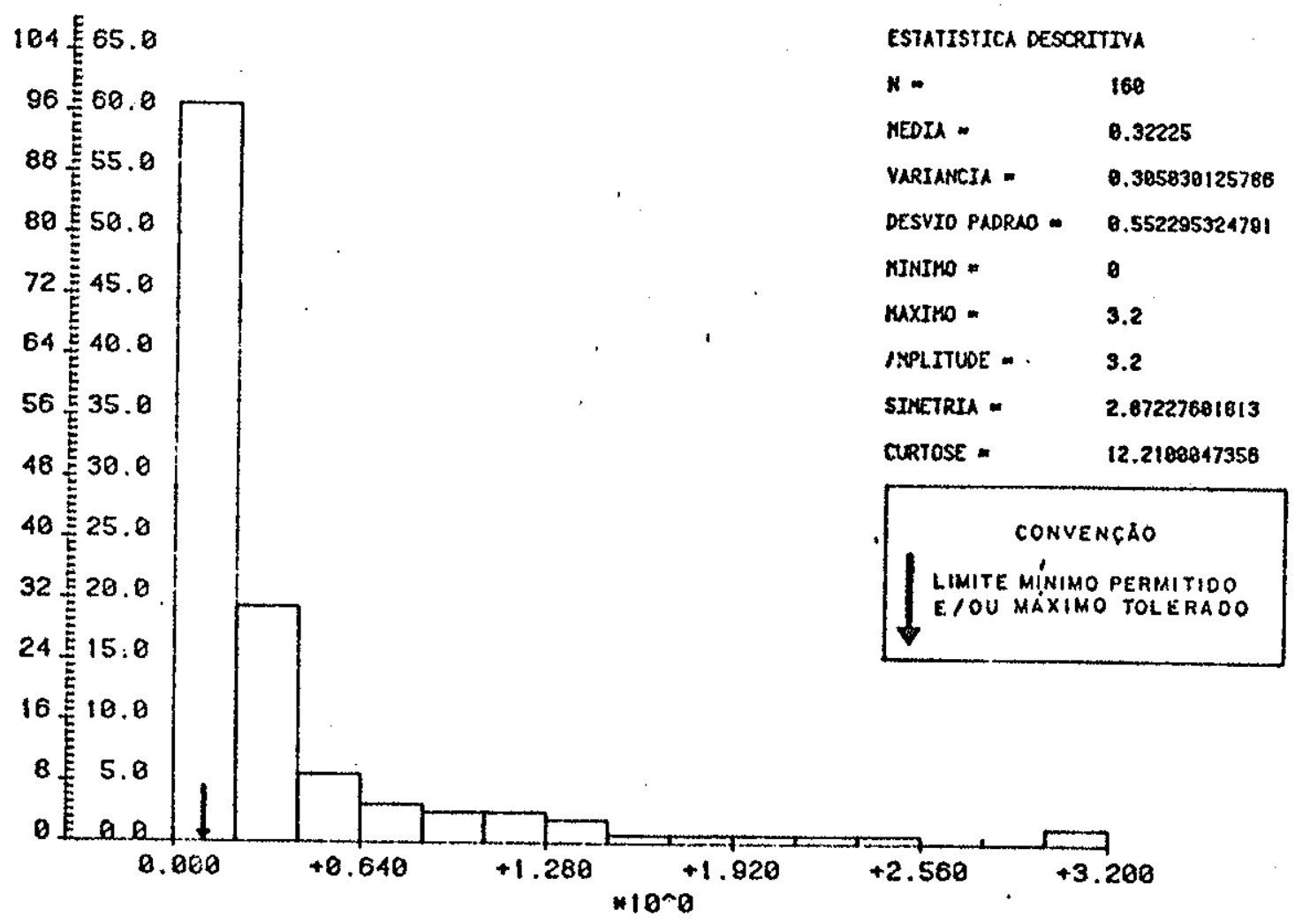

FIGURA 3le - Freqtência dos teores de Ferro (mg/l de Fe) 


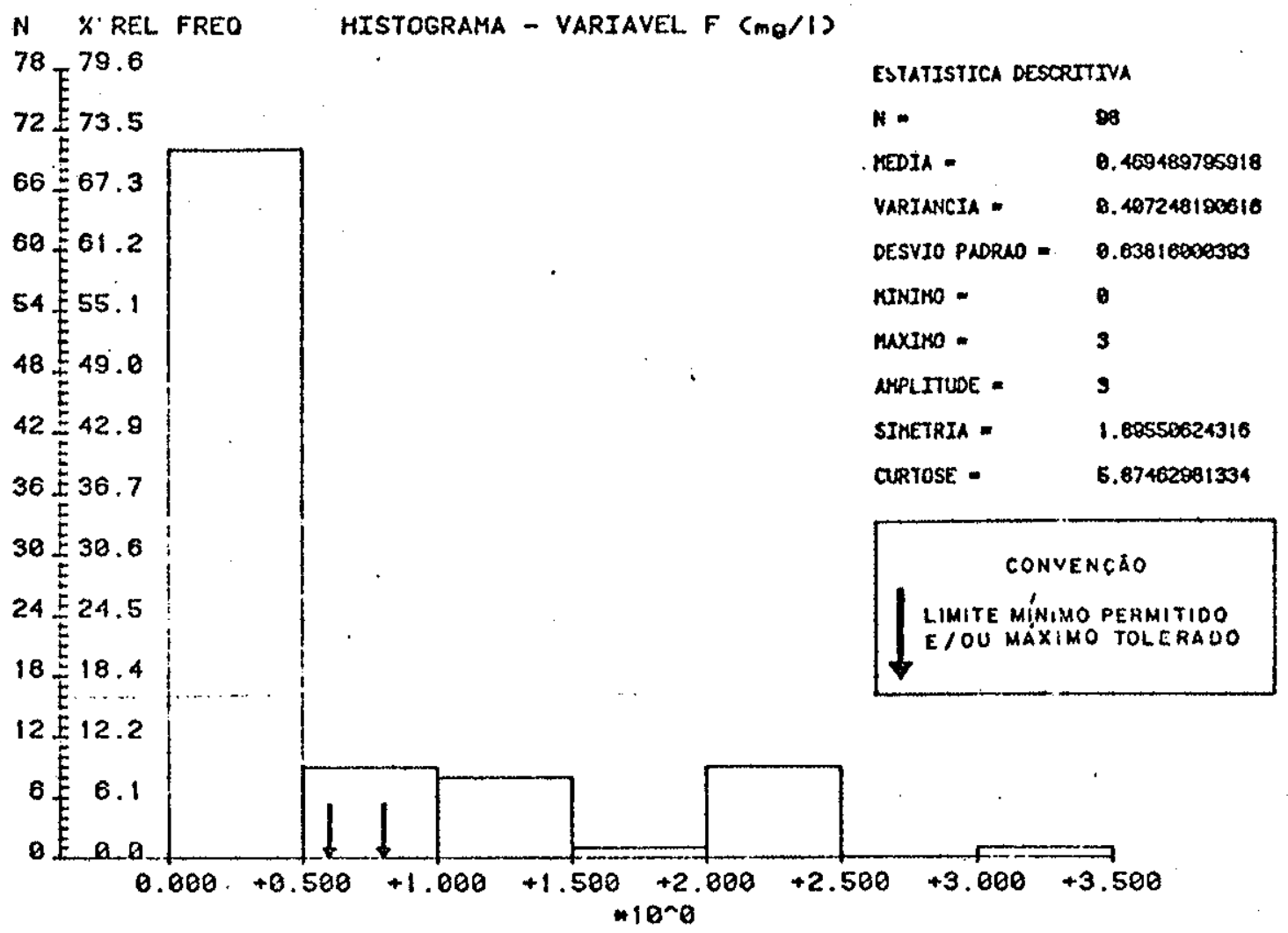

FIGURA $31 f$ - Frequência dos teores de Fluoretos (mg/le $\mathrm{F}^{-1}$ )

N \% REL FREO HISTDGRAMA - VARIAVEL CI (mo/i)

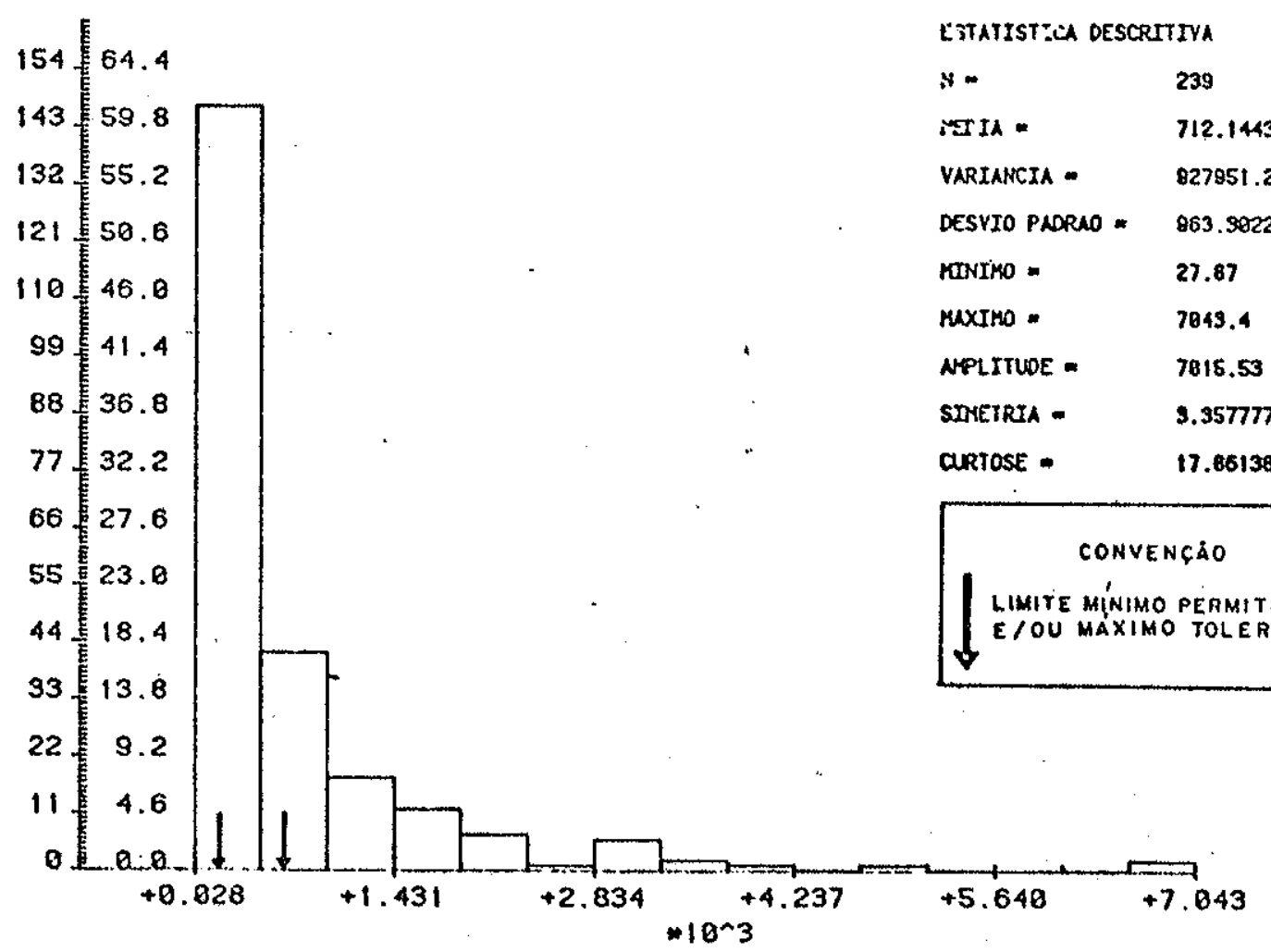

FIGURA $3 \mathrm{lg}$ - Frequência dos teores de cloretos $\left(\mathrm{mg} / 1 \mathrm{Cl}^{-1}\right.$ ) 


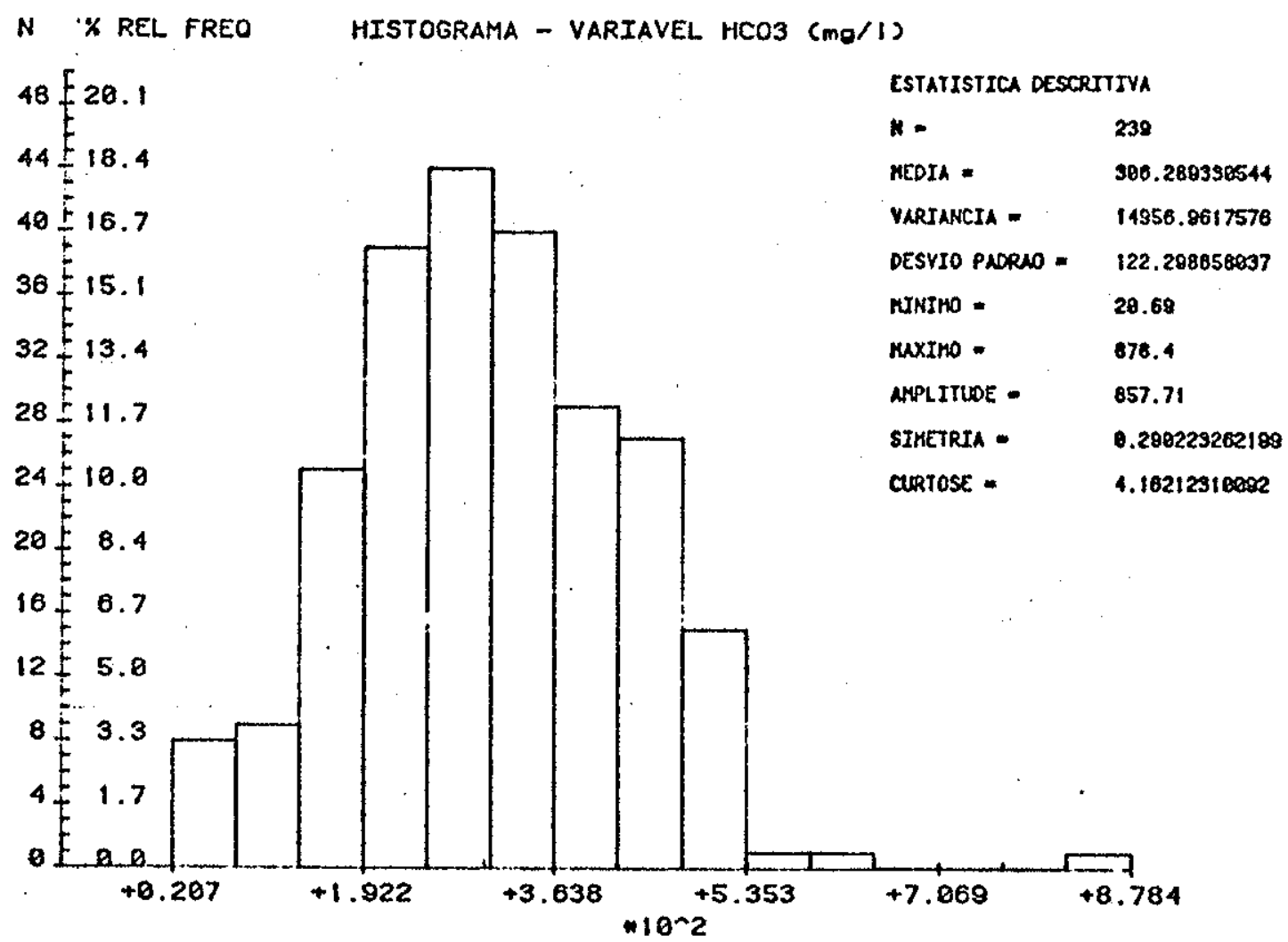
FIGURA 3ih - Frequència dos teores de Bicarbonatos (mg/1

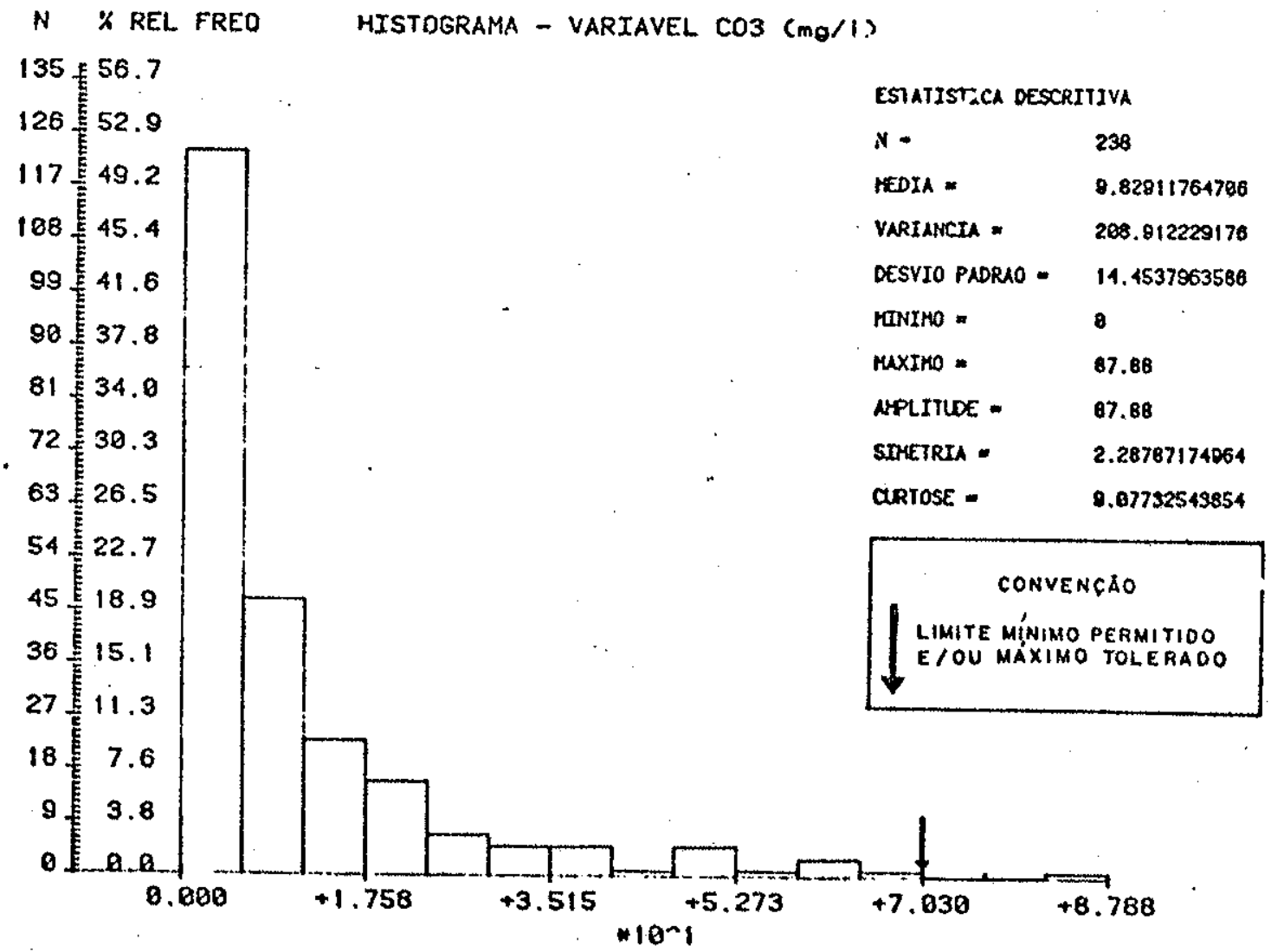

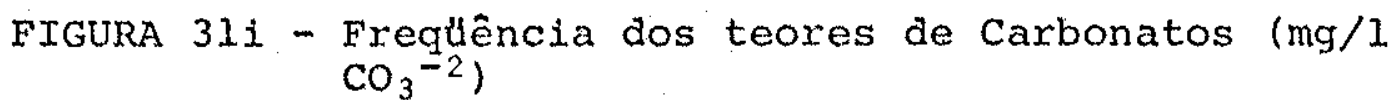




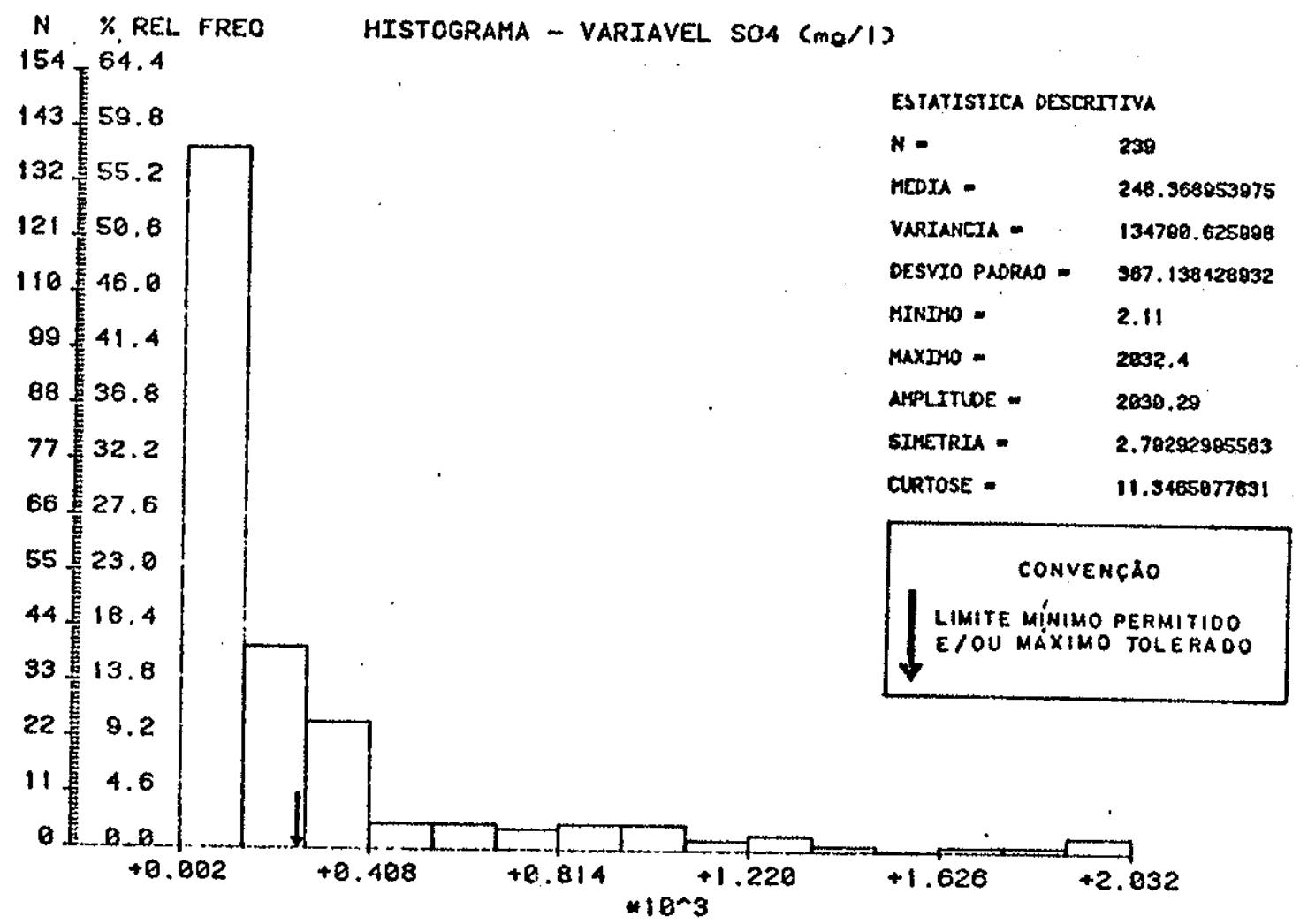

FIGURA $31 j$ - Frequência dos teores de sulfatos (mg/l $\mathrm{SO}_{4}^{-2}$ )

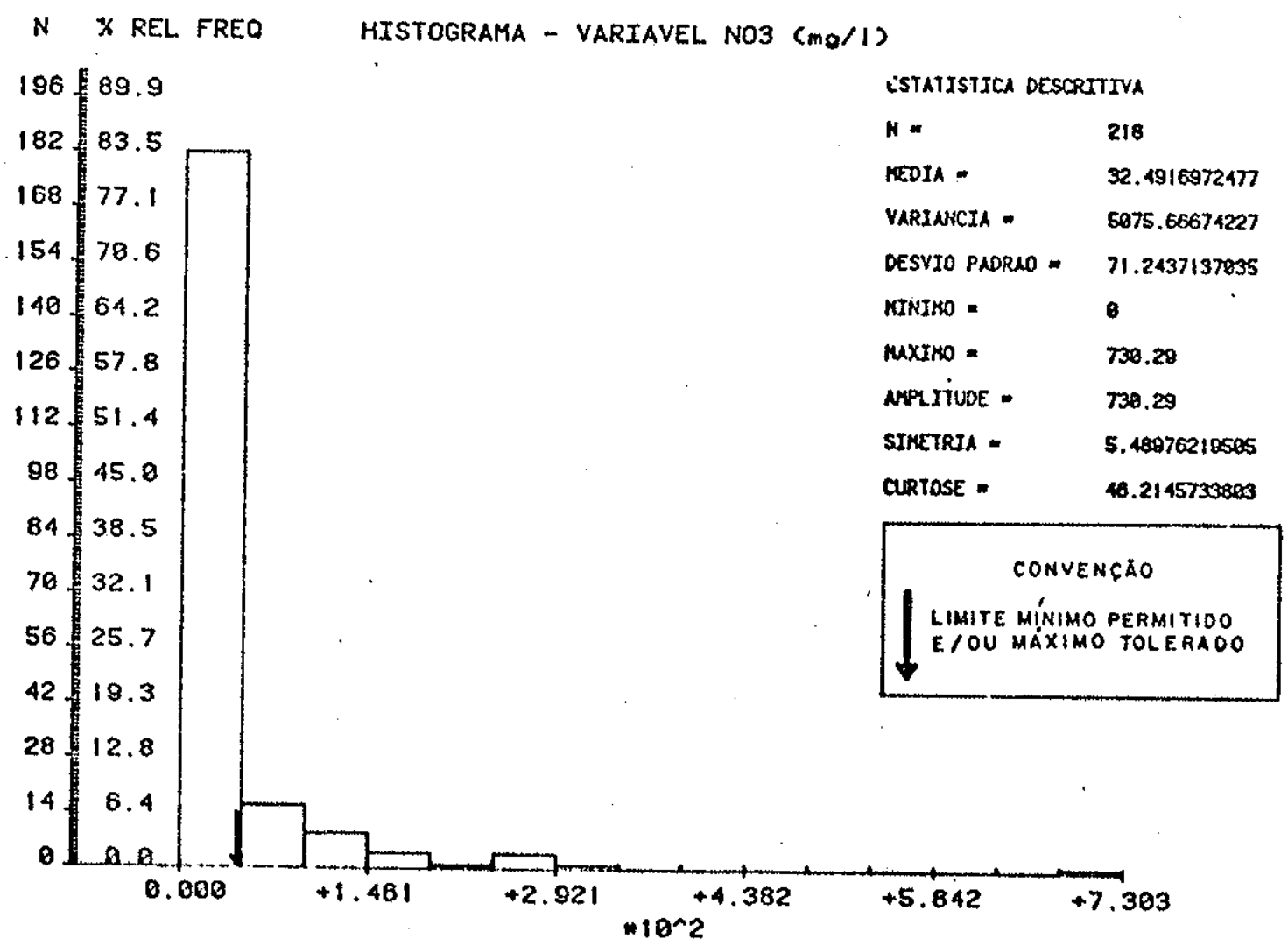

FIGURA $31 \mathrm{k}$ - Frequência dos teores de Nitratos (mg/l $\mathrm{NO}_{3}^{-1}$ ) 
N $X$ REL FREO HISTORRA:4A. VARTAVEL pH de LEh.

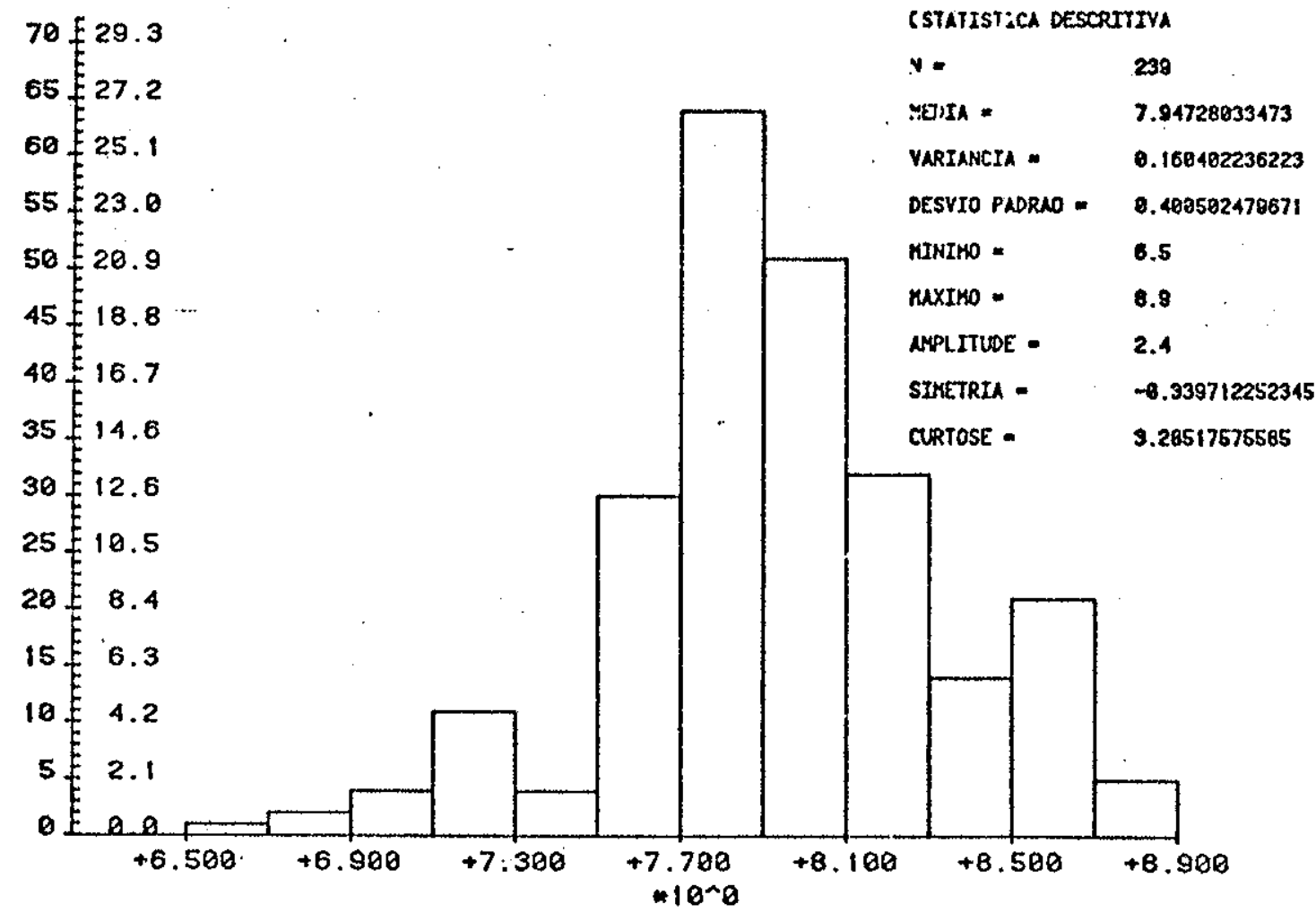

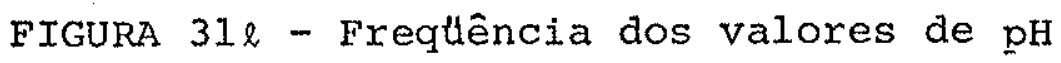

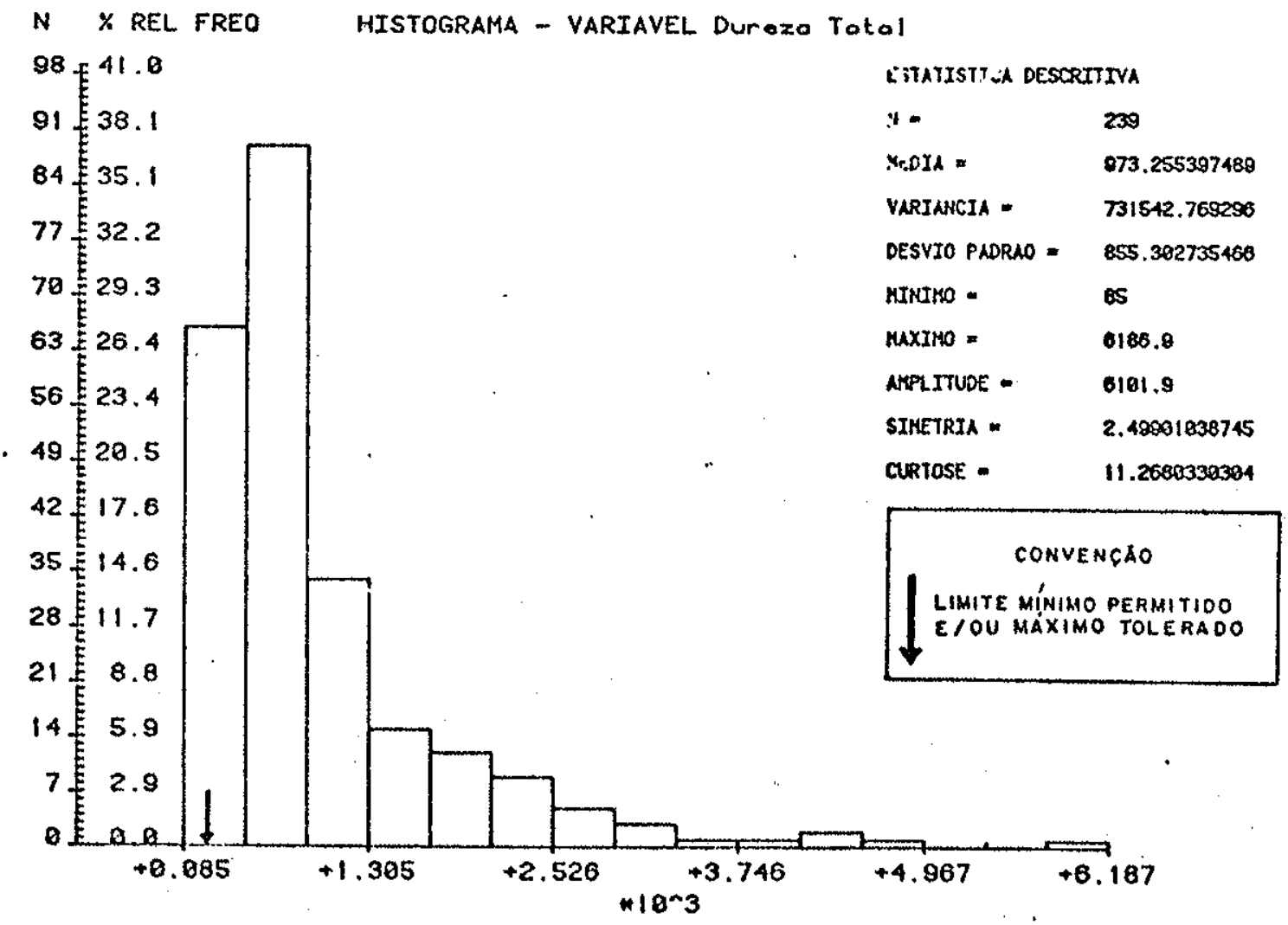

FIGURA 3lm - Frequência dos valores de Dureza total (mg/l $\mathrm{CaCO}_{3}$ equivalente) 
N \% REL FRED HISTOGRAMA - VARIAVEL CE (Umho/cm)

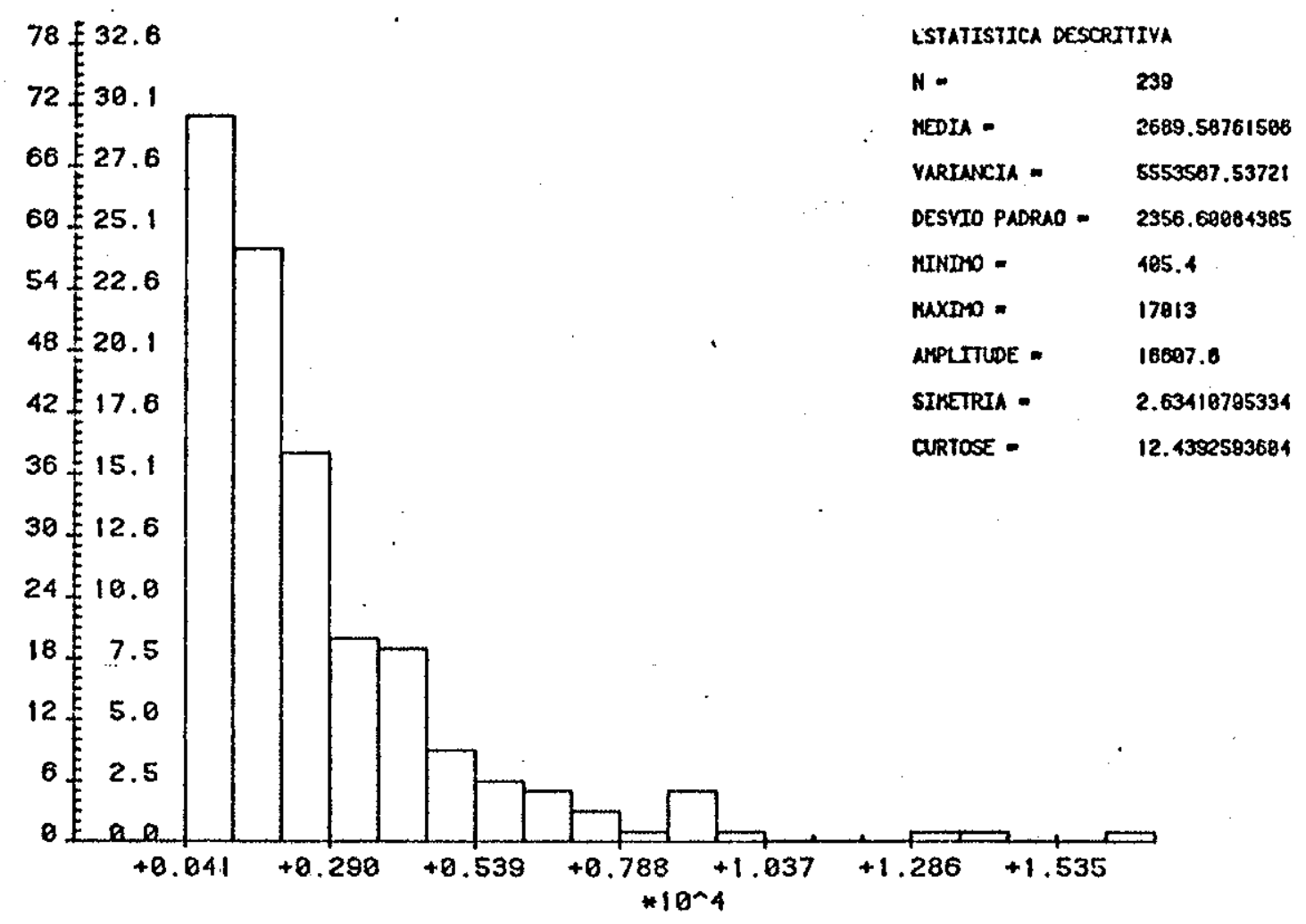

FIGURA 3 ln - Frequência dos valores de condutividade elétrica (CE) a $25^{\circ} \mathrm{C}$.

$N$ * REL FREO HISTOSRAMA DE TSD $(\mathrm{mg} / 1)$

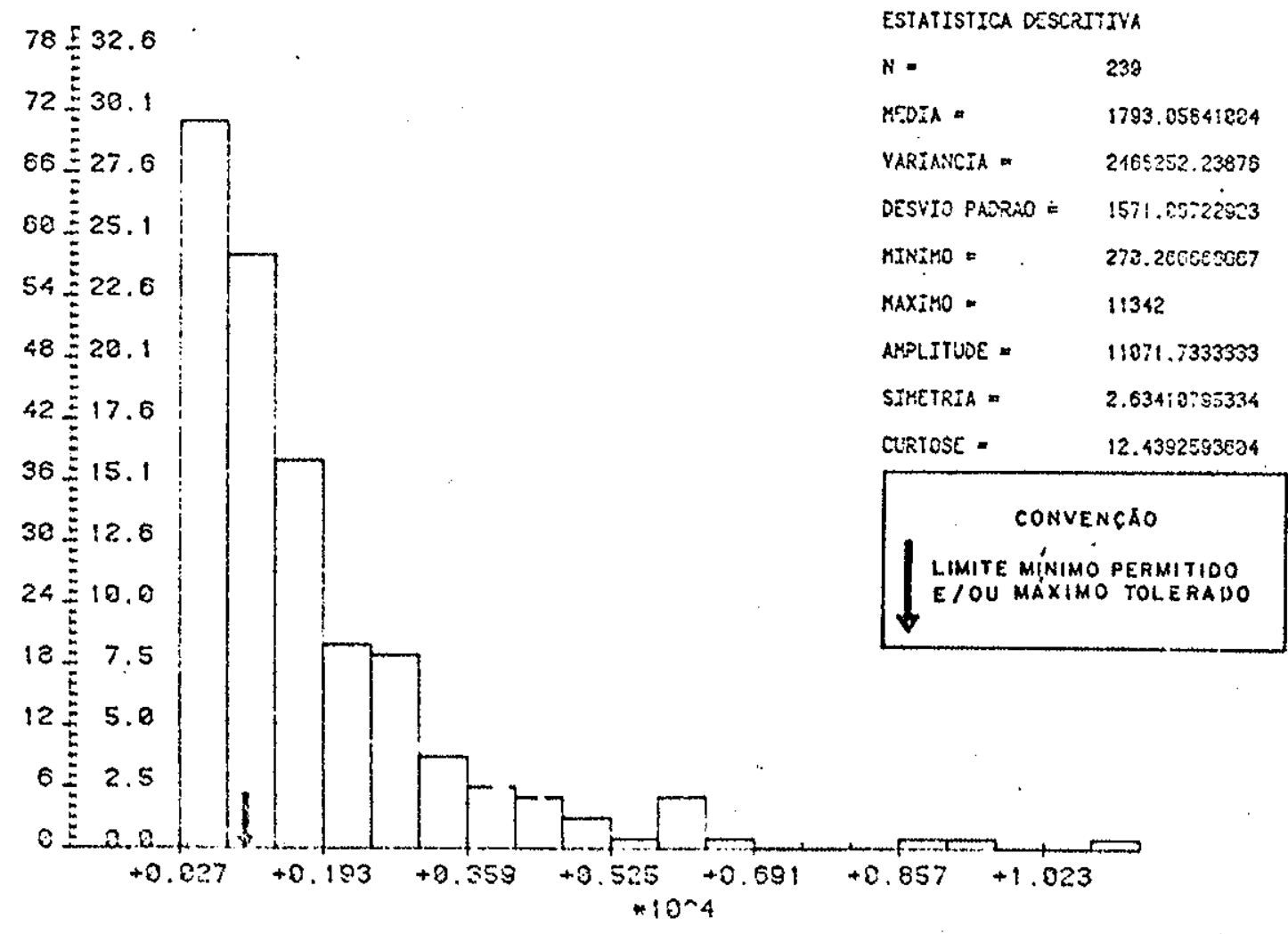

FIGURA 310 - Frequência dos valores de TSD (mg/1). 


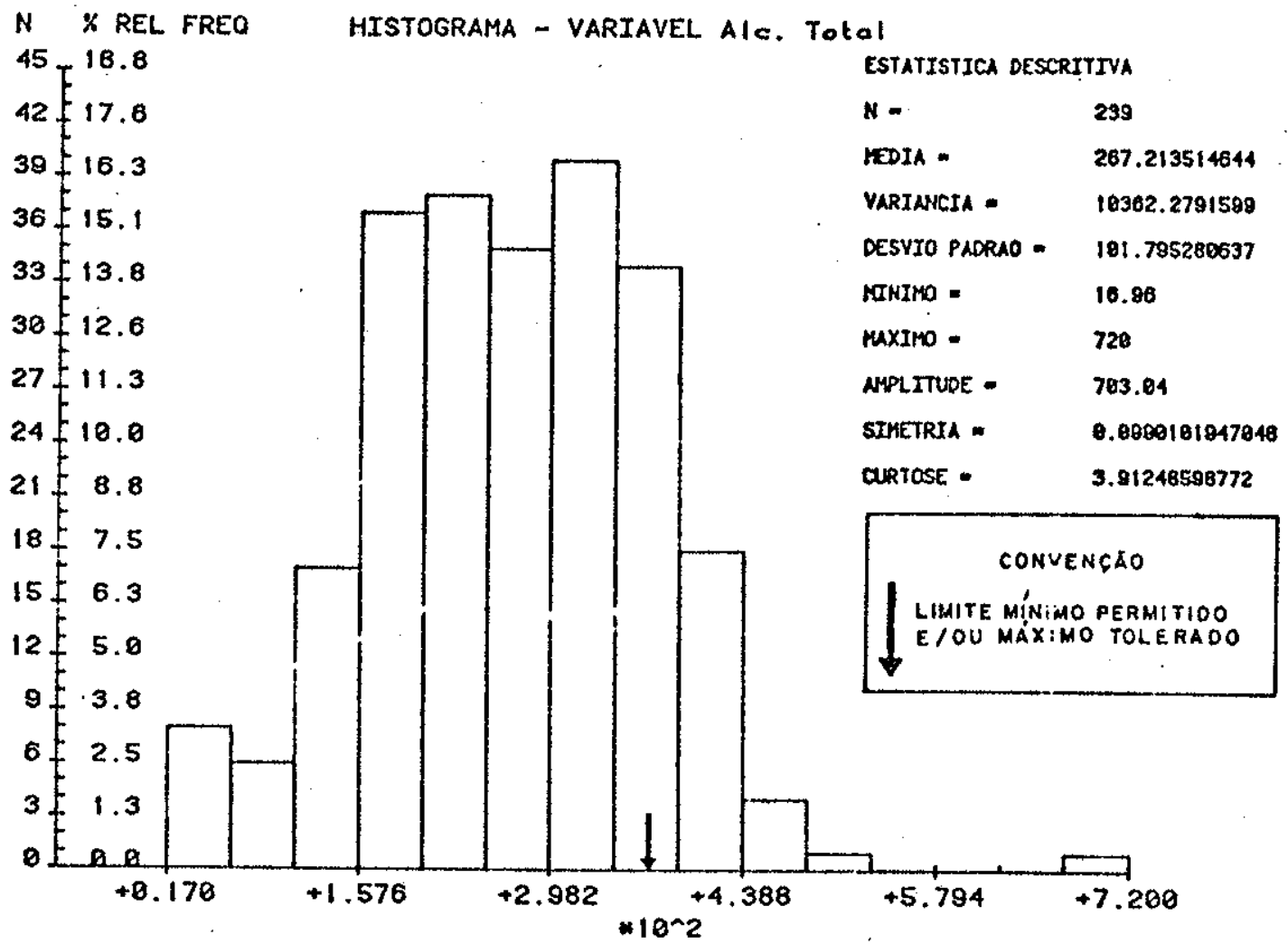

FIGURA 3lp - Frequência dos valores de Alcalinidade total (mg/1 $\mathrm{CaCO}_{3}$ equivalente).

$N$ X REL FREO hItOgDANA - VAPIAVEL Alc. Porfiol

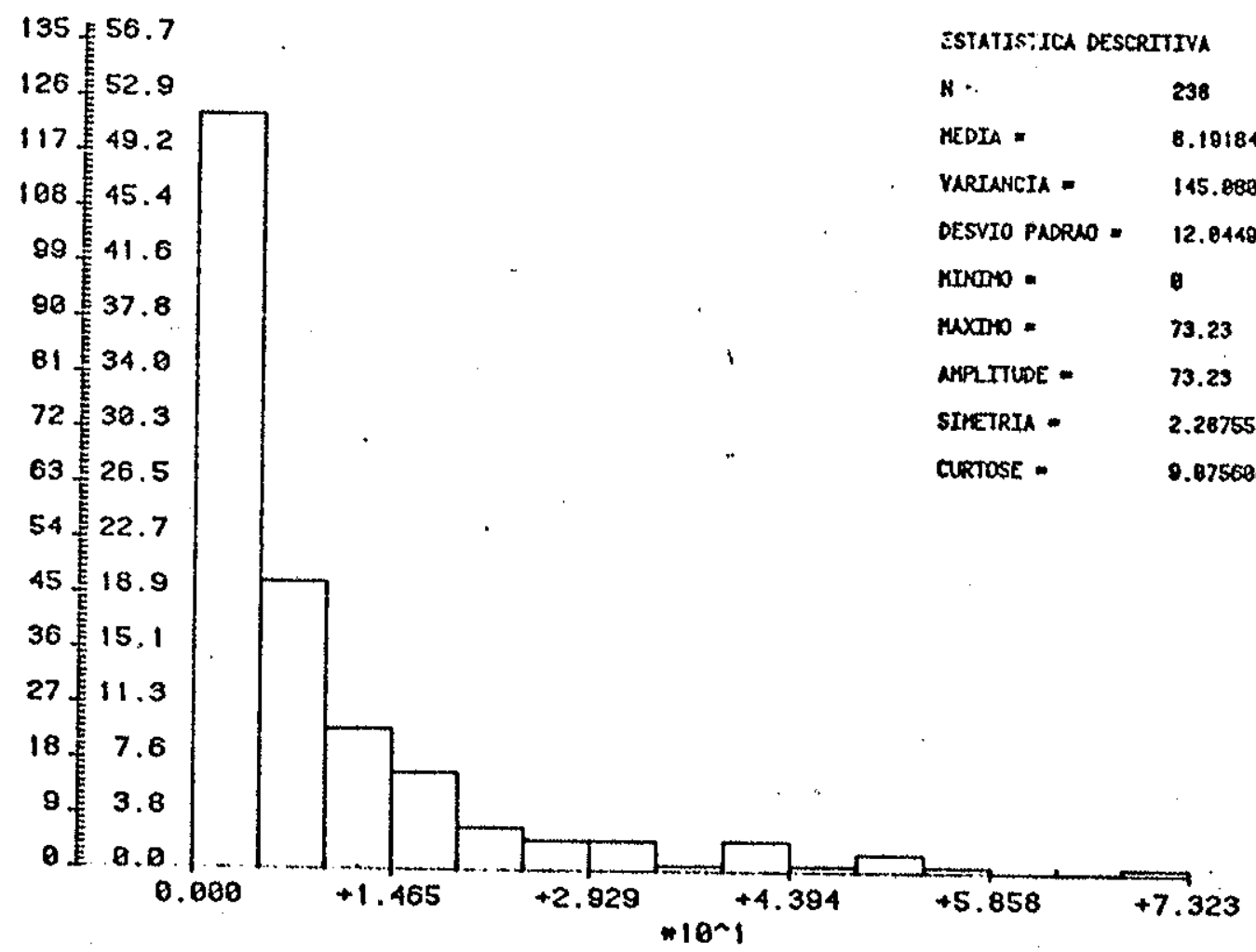

FIGURA $31 q$ - Frequência dos valores de Alcalinidade parcial (mg/1 $\mathrm{CaCO}_{3}$ equivalente). 
$\mathrm{C}_{1}$ - Condutividade elëtrica (CE) e Residuo seco (RS)

Somente 95 laudos de anälises apresentavam valores de RS medidos em laboratório. Com esses dados foi então avaliada a re lação com a condutividade elētrica representada na FIGURA 32 .

Da anälise de regressão efetuada obteve-se a seguinte equa Ção para expressar a relação entre a condutividade elétrica (CE) a $25^{\circ} \mathrm{C}$ e o residuo seco (RS) a $105^{\circ} \mathrm{C}: \mathrm{CE}=3,04$ RS.

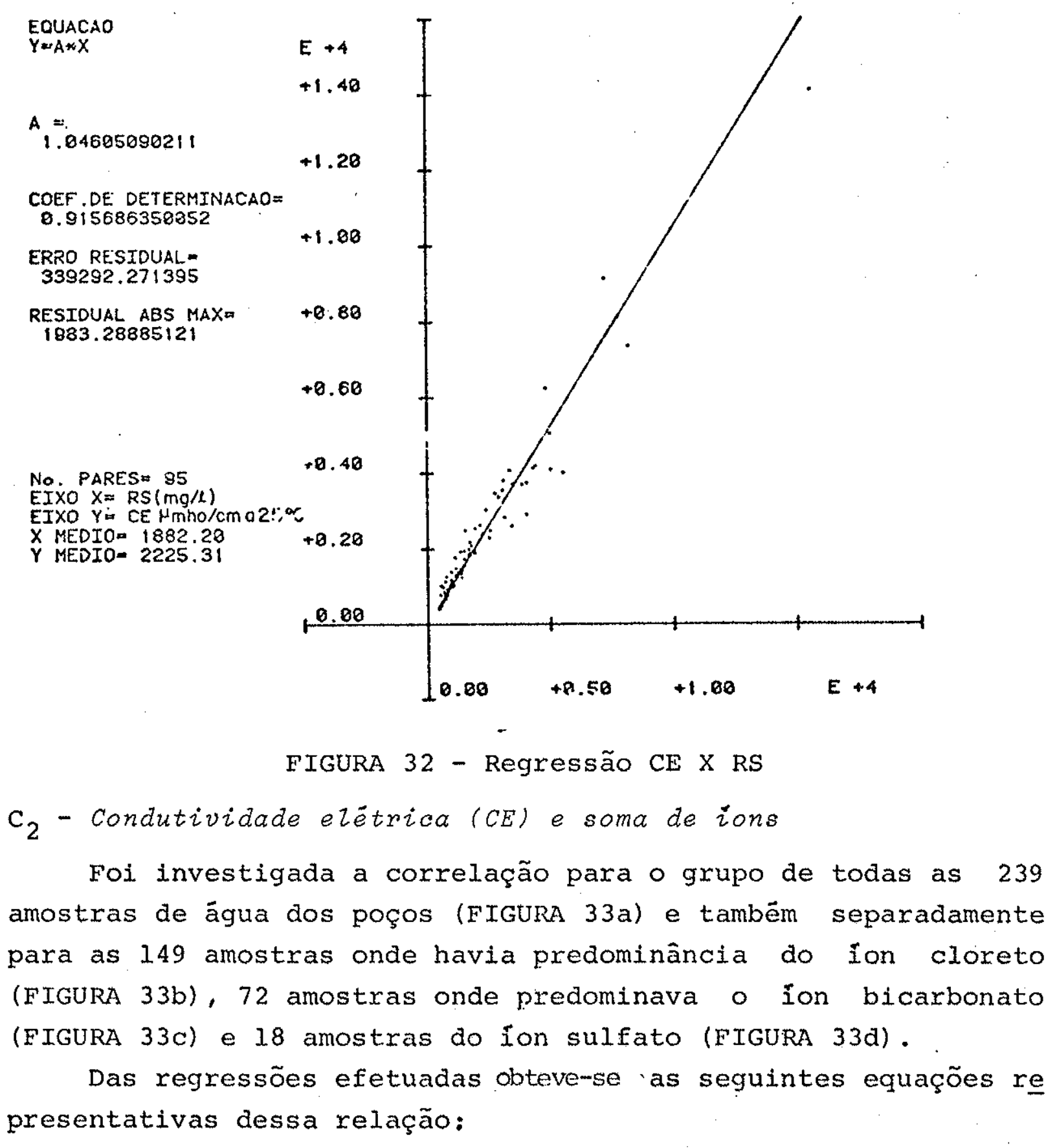




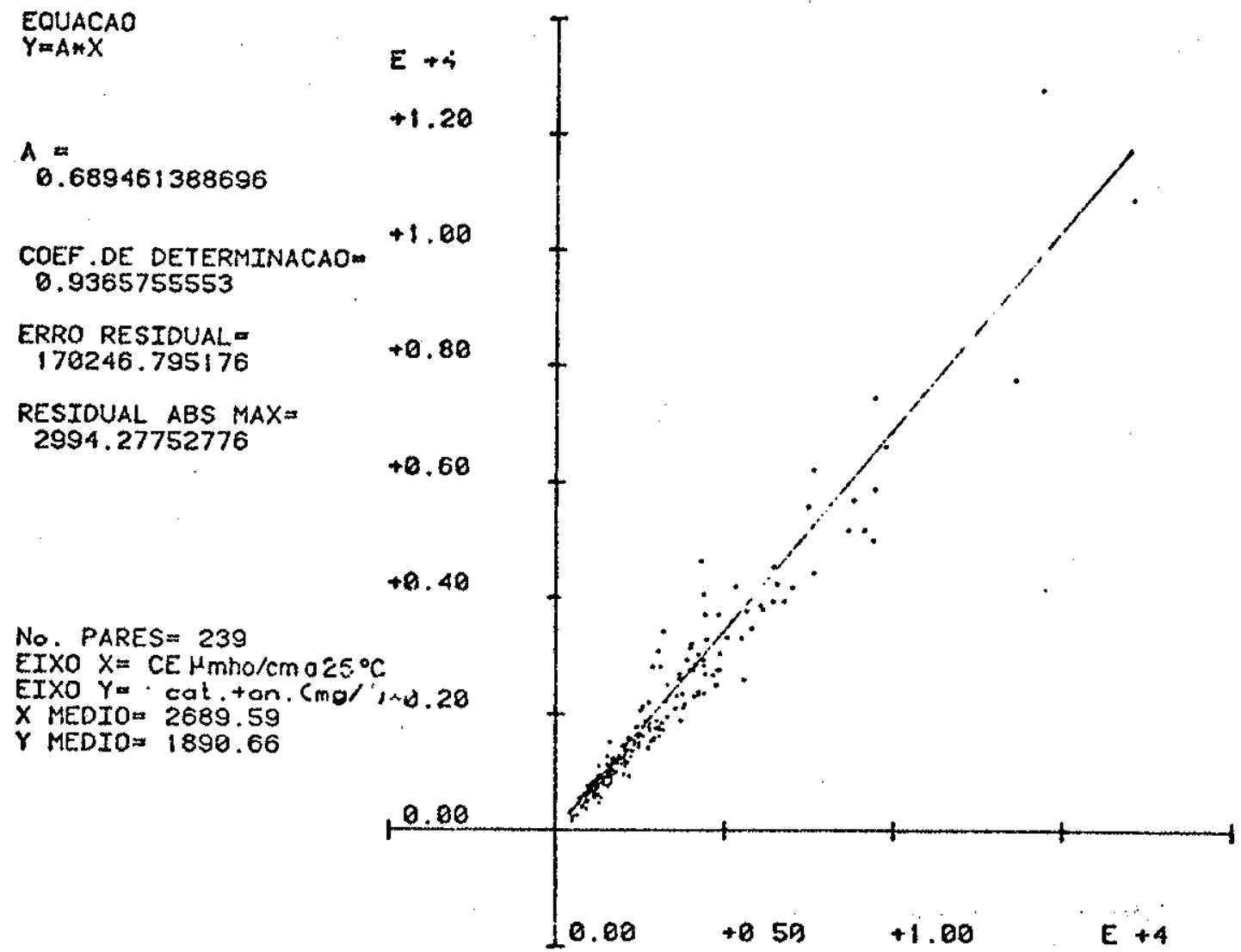

FIGURA 33a - Regressão: CE x Soma de Eons para o conjunto das. 239 amostras.

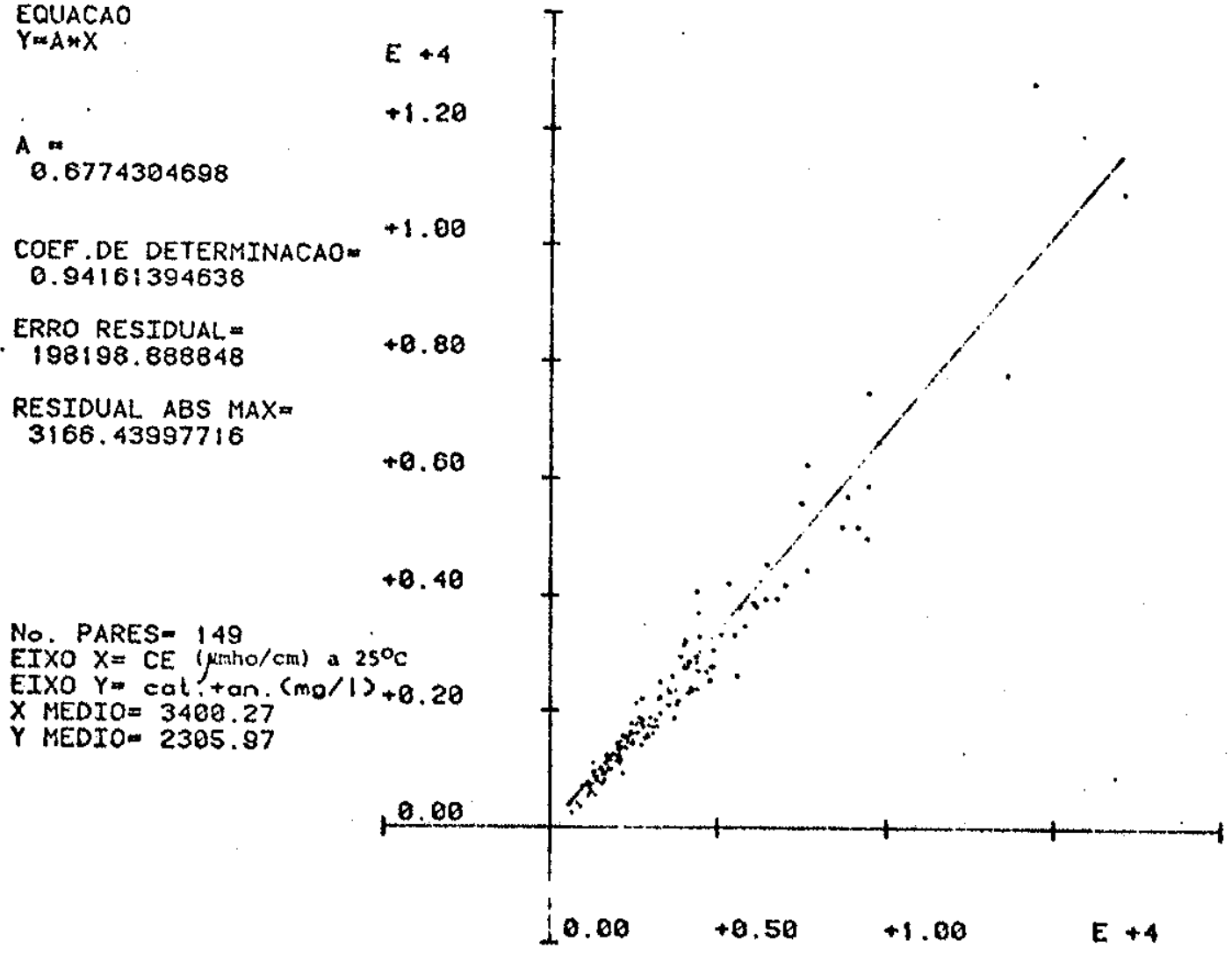

FIGURA 33b - Regressão: CE $x$ Soma de ions para äguas com dominância de cloretos. 


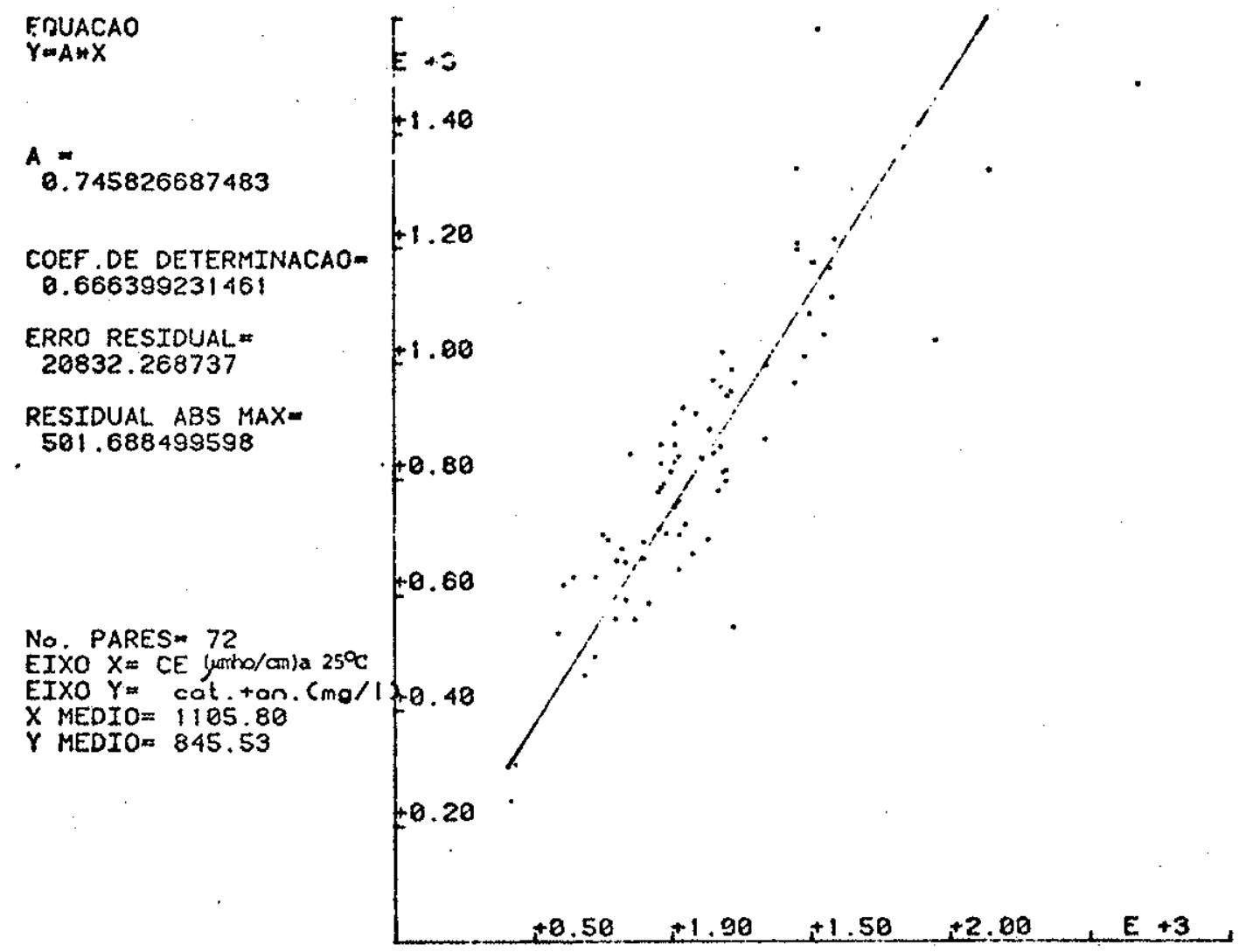

FIGURA 33c - Regressão: CE x Soma de ĩons para ãguas com dominância de bicarbonatos.

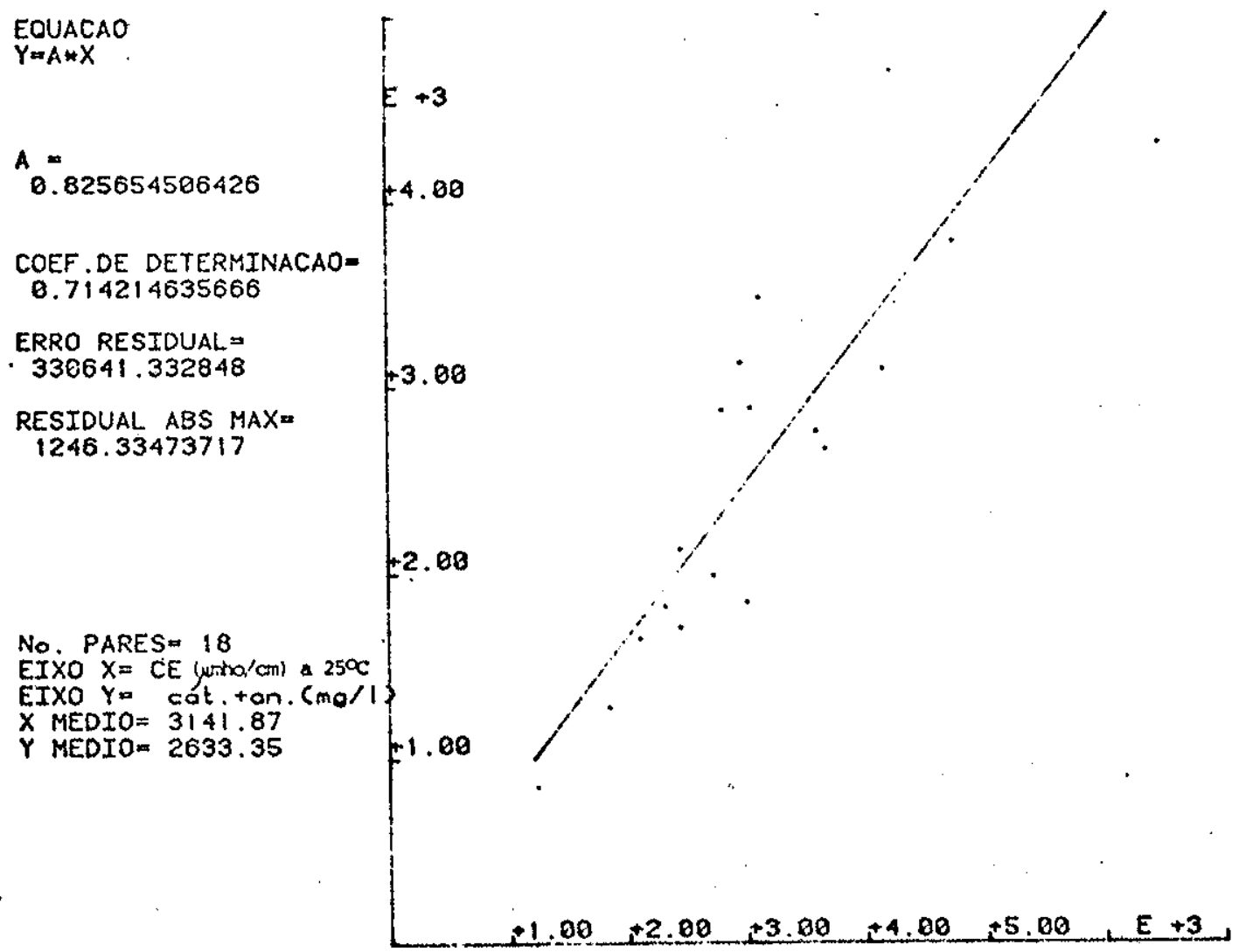

FIGURA 33d - Regressão: CE x Soma de Ĩons para âguas com dominância de sulfatos. 


$$
\begin{aligned}
& C E=0,68 \times(\Sigma \text { cátions +ânions }) \text { - para todo o grupo } \\
& C E=0,67 \times(\Sigma \text { cátions +ânions })-\text { para as águas"cloretadas" } \\
& C E=0,74 \times(\Sigma \text { cátions +ânions })-\begin{array}{l}
\text { para as águas "bicarbona- } \\
\text { tadas" }
\end{array} \\
& C E=0,82 \times(\Sigma \text { cátions +ânions }) \text { - para as águas sulfatadas, }
\end{aligned}
$$

\section{$c_{3}$ - Condutividade elétrica e Vazão específica}

A relação entre a condutividade elétrica e a vazão especí fica é apresentada na FIGURA 34.

pode-se verificar, pelo baixo valor do coeficiente de de terminação que praticamente não há dependência entre as variä veis, a não ser para valores bastante baixos de $Q / s$.

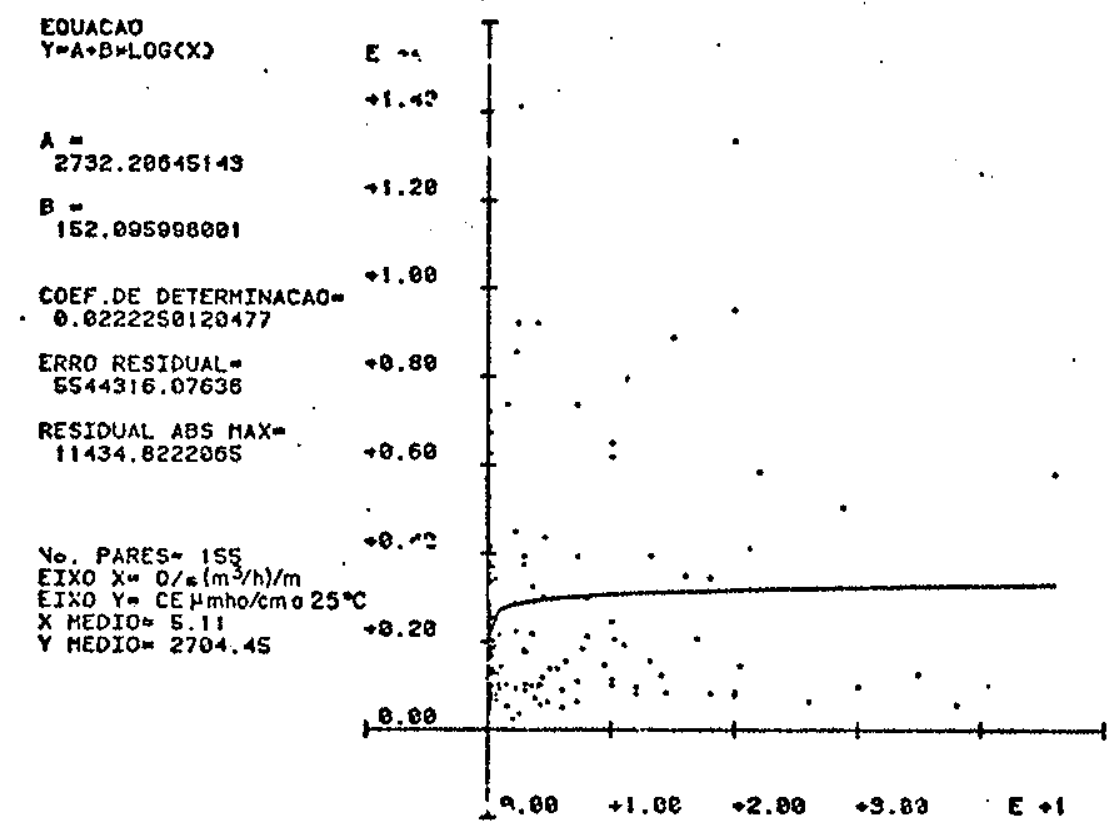

FIGURA 34 - Regressão; CE $\times$ Q/s

$c_{4}$ - Condutividade elétrica e transmissividade

A FIGURA 35 representa a curva de melhor ajuste entre $C E$ e T.

pode-se notar pela curva de melhor ajuste e pelo baixo va Ior do coeficiente de determinação que, a menos da correspondên cia para valores bastante baixos de $T$, inexiste relação entre esses parâmetros 


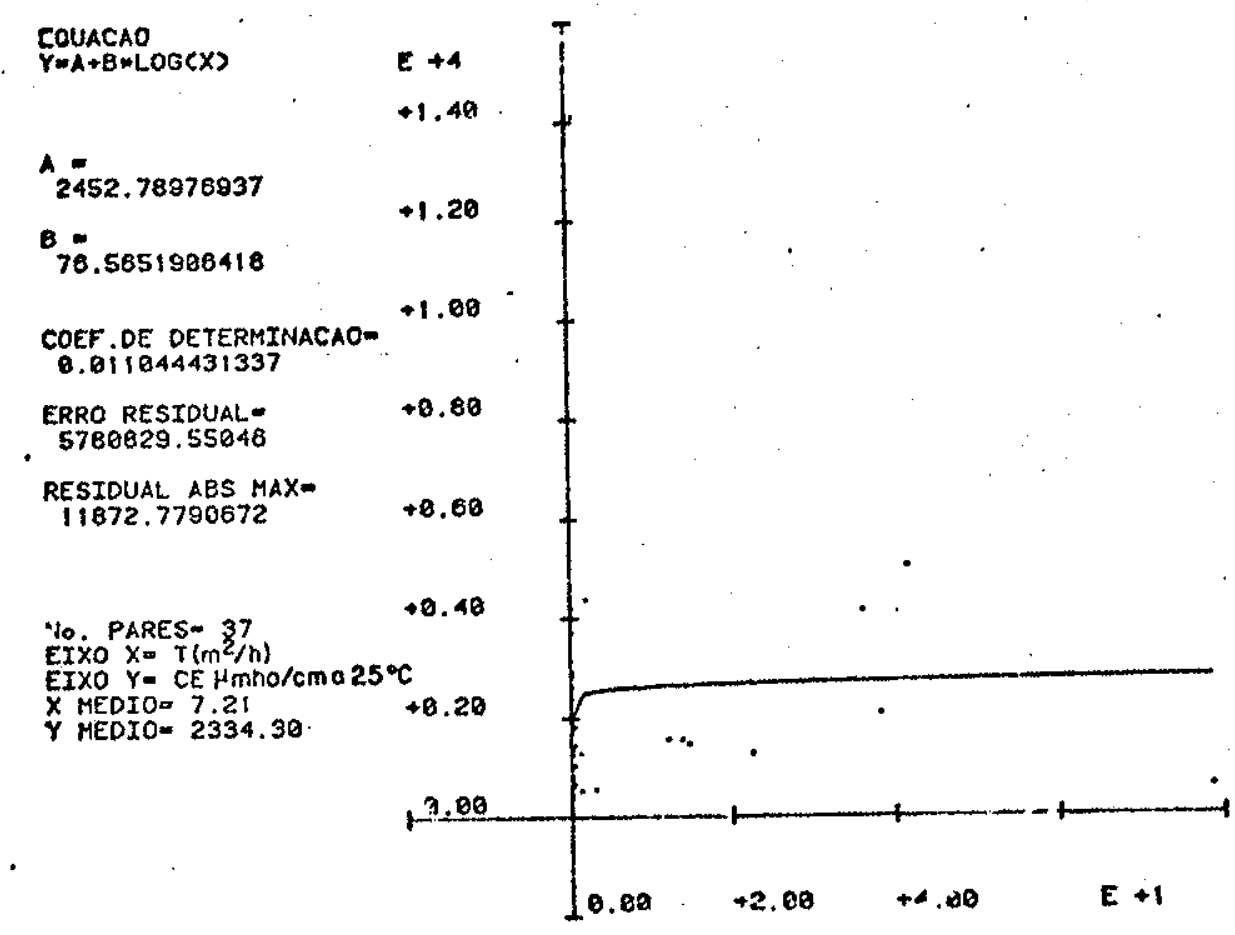

FIGURA 35 - Regressão: CE X T

$c_{5}$ - Condutividade elétrica (CE) e profundidade do nîvel estät co $(N E)$.

Na FIGURA 36 está representada a regressão linear, baseada na curva de melhor ajuste para os valores de $C E$ e NE.

pode-se verificar, pelo baixo valor do coeficiente de de terminação que praticamente inexiste uma relação estreita entre esses parâmetros, a menos de uma branda redução da condutivida de com o aprofundamento dos níveis d'água.

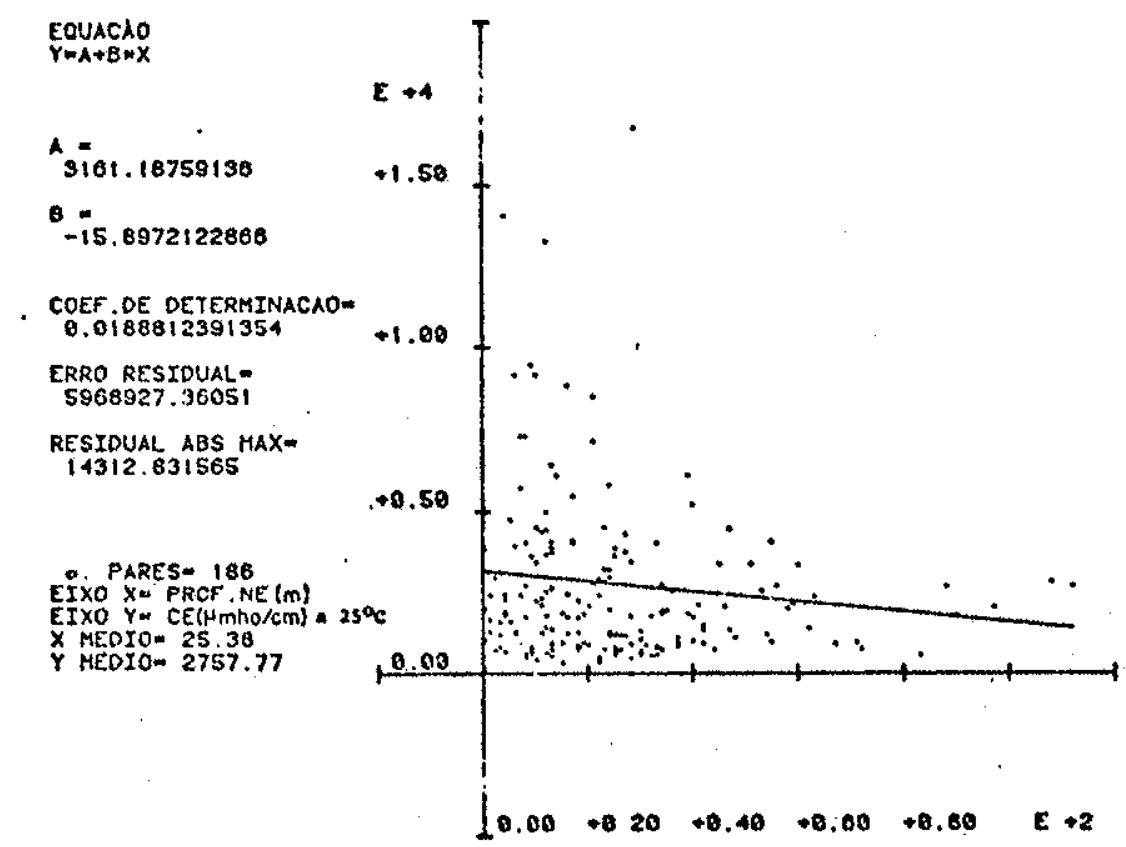

FIGURA 36 - Regressão: CE $x$ prof NE 
$\mathbf{c}_{6}$ - Condutividade elétrica (CE) e espessura da cobertura

Com o objetivo de avaliar a influência das águas armazena das nos sedimentos de cobertura (Sistema Dunas-Barreiras) sobre a salinidade das āguas do aquífero Jandaíra nessas áreas, foi investigada a relação citada, apresentada na FIGURA 37.

Pelo reduzido valor do coeficiente de determinação pode-se verificar que praticamente inexiste dependênciaientre essas va riáveis, a menos de uma incipiente redução da condutividade elé trica com o aumento das espessuras dos sedimentos de cobertura.

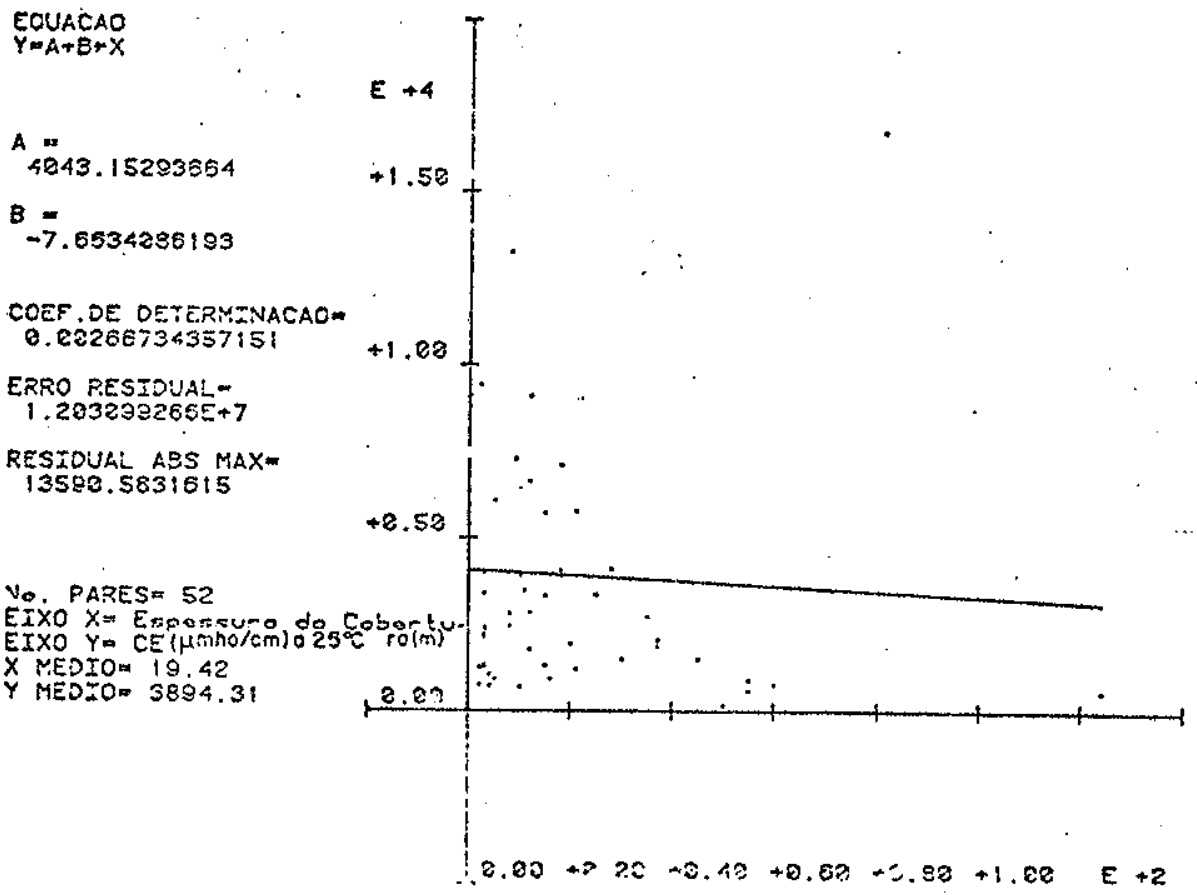

FIGURA 37 - Regressão: CE x espessura dos sedimentos de cobertu ra dos calcärios.

$c_{7}$ - Soma de ions e cloretos

Na FIGURA 38 está representada a reta correspondente à re lação de dependência entre o total de cátions e ânions, expres sos em $\mathrm{mg} / 1$, e os teores de cloretos.

Pode-se notar pelo elevado coeficiente de determinação a estreita interdependência entre essas variáveis, onde a partici pação dos cloretos é crescente com a soma de ânions, numa rela ção direta, portanto com a salinidade das águas. 


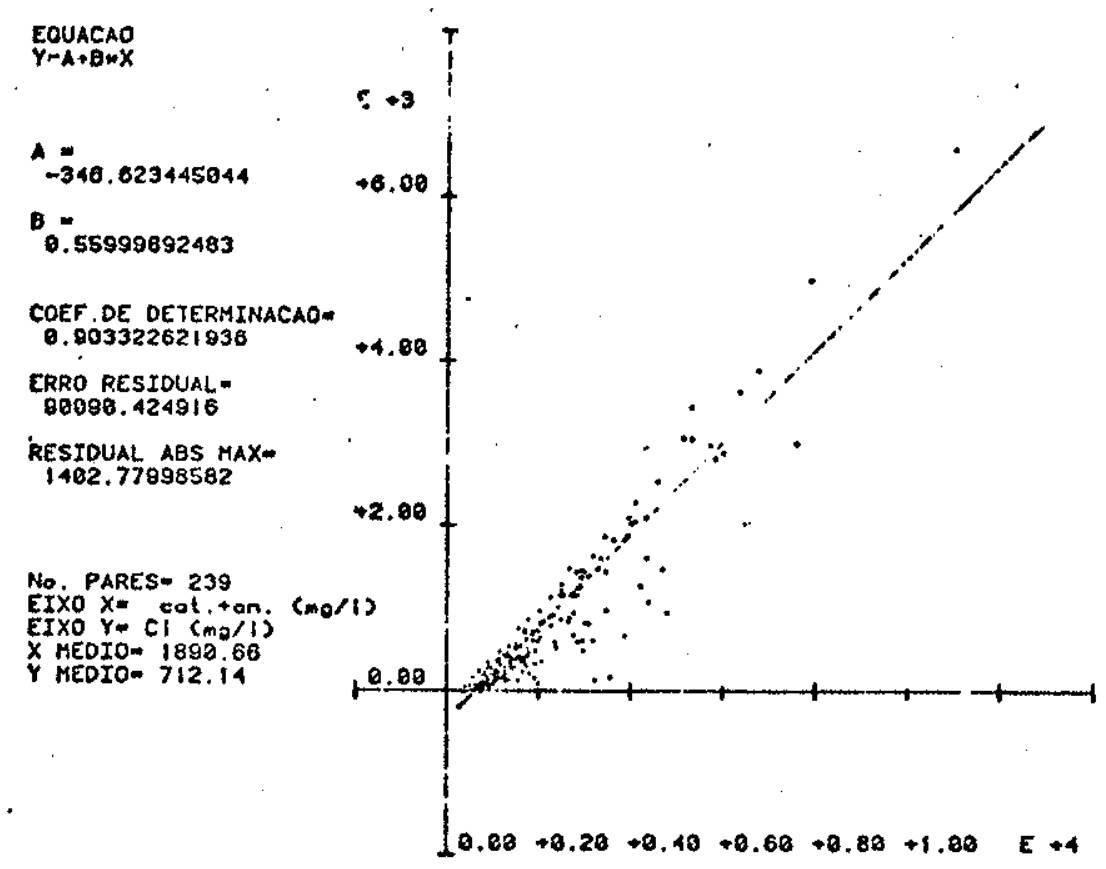

FIGURA 38 - Regressão: soma de ions $x$ cloretos.

$c_{8}$ - Soma de ions e bicarbonatos

A regressão entre a soma de cátions e ânions e os bicarbo natos é apresentada na FIGURA 39 , podendo-se notar que praticá mente inexiste relação entre as variáveis evidenciando um leve decréscimo nos teores de bicarbonatos à medida que aumenta a so ma de ions denotando a pequena influência dos bicarbonatos na salinidade das águas. Nota-se também que hã limitações para os teores máximos de bicarbonatos em função da soma de ions.

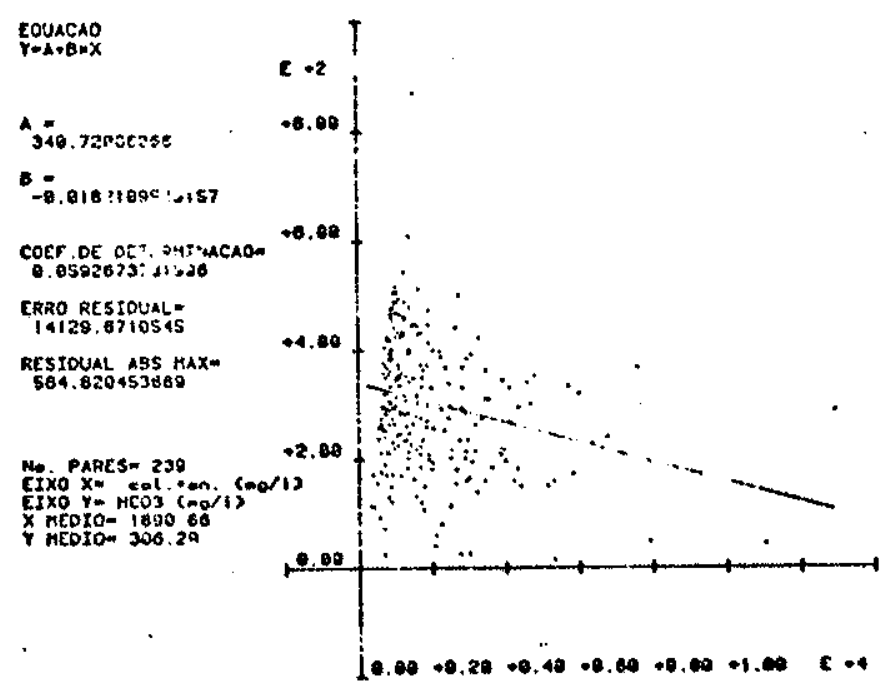

FIGURA 39 - Regressão: soma de Ions $x$ bicarbonatos 
$\mathrm{c}_{9}$ - Soma de ions e sulfatos

Na FTGURA 40 estä representada a regressão de melhor ajus te para esta relação, podendo-se notar, pelo baixo coeficiente de determinação, a fraca influência dos sulfatos sobre a soma de cātions e ânions. Nota-se que há porém um limite para os teo res māximos de sulfatos em função da soma de Ions.

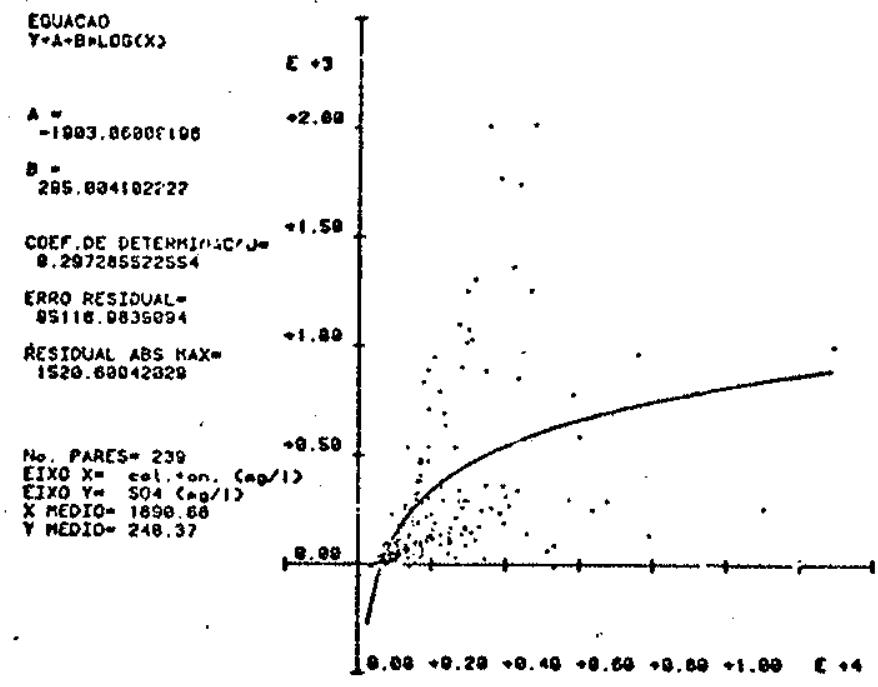

FIGURA 40 - Regressão: soma de íons $x$ sulfatos.

$\mathrm{c}_{10}$ - Soma de ions e sódio

A curva de melhor ajuste que expressa a relação entre as somatórias de cätions e ânions e os teores de sódio é apresenta da na FIGURA 4l. Verifica-se pelo elevado coeficiente de deter minação a estreita relação entre essas variáveis, com os teores de sódio crescendo diretamente com a soma de Ions.

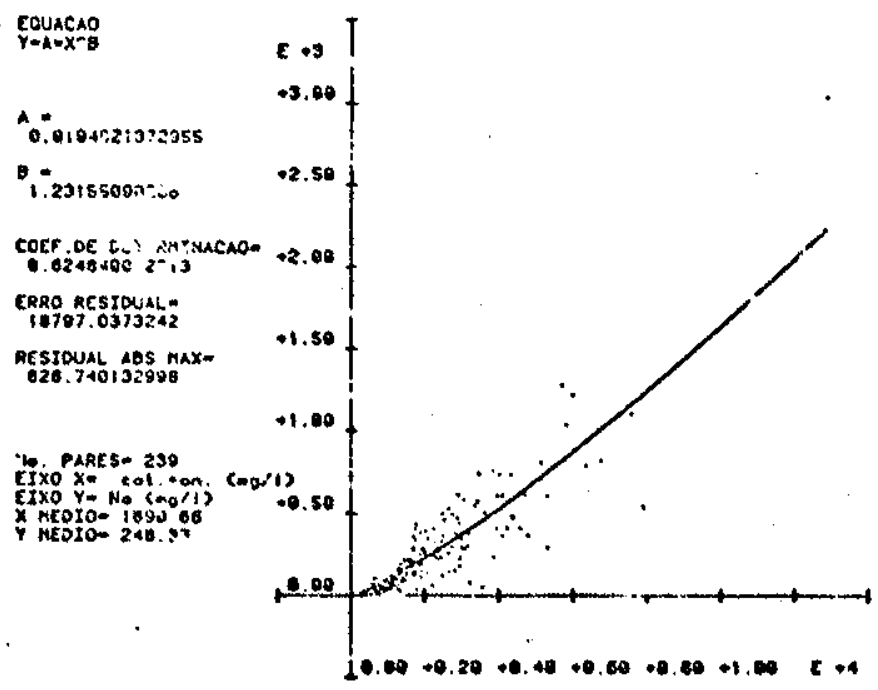

FIGURA 41 - Regressão: soma de íons $x$ södio 
$c_{11}$ - Profundidade dos posos e cloretos

Verificados os altos teores em cloretos e a sua relação com outros constituintes e parâmetros, procurou-se investigar o seu significado em āguas de captação mais profundas. A FIGURA 42 apresenta a curva de melhor ajuste para expressar a relação entre essas variáveis.

Pode-se notar, pelo baixo coeficiente de correlação que praticamente inexiste influência da profundidade do poço no teor em cloretos das águas, embora haja um reduzido decréscimo dos seus teores com o aumento da profundidade.

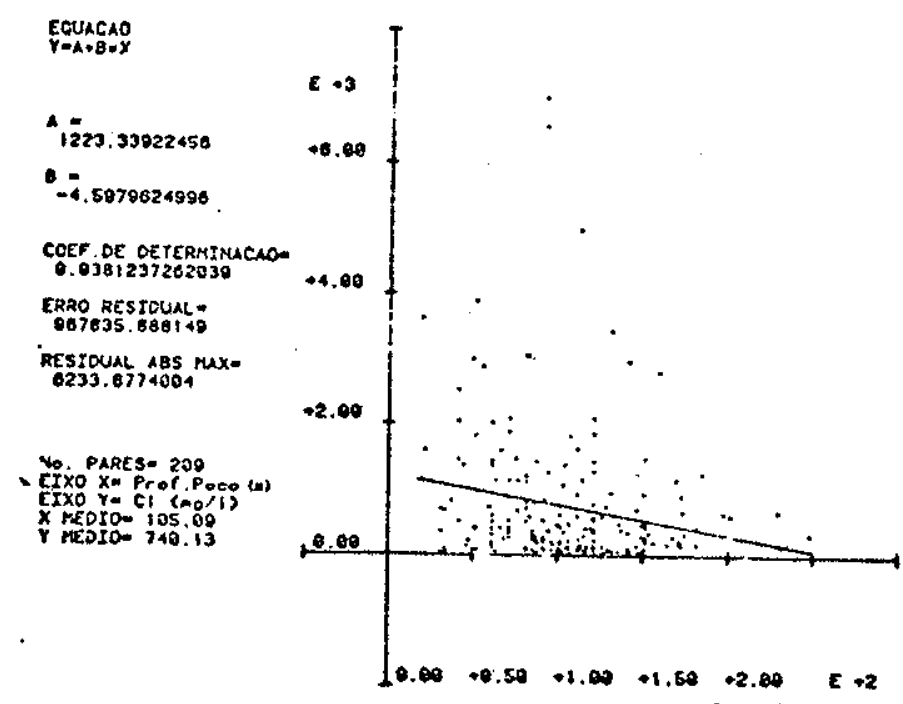

FIGURA 42 - Regressão: profundidade dos poços $x$ cloretos.

d) Relagão entre Residuo seco e Pluviosidade

objetivando investigar as relações entre fenômenos meteo rológicos e a salinidade das águas, foi elaborado o gráfico a presentado na FIGURA 43, que relaciona a pluviometria e a varia ção do conteưdo salino, expresso em Residuo seco a $110^{\circ} \mathrm{C}$, nas $\underline{\bar{a}}$ guas de alguns poços e cacimbas no domínio dos calcários Janda ra. Os dados utilizados são apresentados na TABELA 20, ANEXO B. A pequena quantidade de dados de RS e a descontinuidade temporal da amostragem não permitiu uma análise detalhada dos fenômenos envolvidos.

Inversamente ao que se poderia esperar, nota-se um aumento da salinidade das ăguas do aquifero com a pluviosidade, variável 


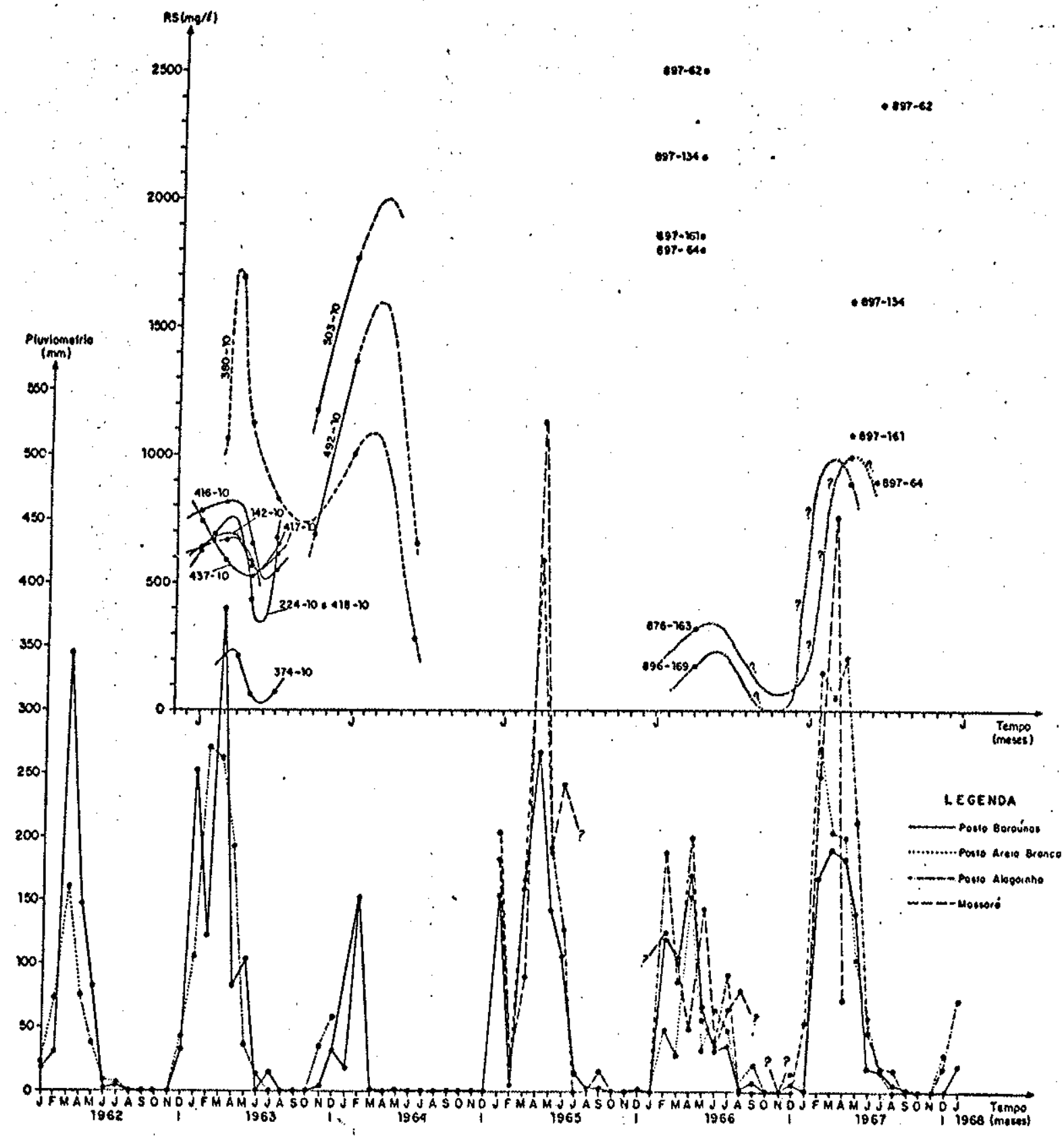

FIGURA 43 - Correlação entre RS em águas de poços e cacimbas e a pluviometria. 
porëm de local para local, e em intervalo de tempo relativamente curto. Esse fato deve estar representando a influẽncia dos solos sobre a composição química das ăguas subterrāneas onde as águas de chuva promoveriam uma grande atividade iônica no meio não saturado e se enriqueceriam em sais antes de aportar na camada aquifera.

A cacimba no 437-10, com comportamento inverso, segundo o inventário da SUDENE (MANOEL FILHO, 1970) capta água do aquífero Açu e portanto deve estar refletindo fenômeno diverso do ocor rente no aquifero Jandaira, pois os solos mais arenosos sobre postos ao aquifero Açu tendo composição diferente dos solos cal cārios promoveriam menor salinização.

\section{e) Grupamento das Aguas do Aquifero Jandaira}

Com o objetivo de identificar grupos de águas que apresen tassem parentesco nos parâmetros físico-químicos e químicos pes quisados foram efetuadas diversas análises de agrupamento. Pa ra essas anälises foi verificada a significação dos agrupa mentos. São apresentados os resultados da anälise em que se utilizou como variáveis os seguintes parâmetros e relações iô nicas: $\mathrm{pH}, \mathrm{CE}\left(\mu \mathrm{mho} / \mathrm{cm}\right.$ a $\left.25^{\circ} \mathrm{C}\right), x \mathrm{Mg} / \mathrm{rCa}, r \mathrm{k} / \mathrm{rNa}, r \mathrm{Na} / \mathrm{rCa}, r(\mathrm{Na}+$ K) $/ x(\mathrm{Ca}+\mathrm{Mg}), \quad r \mathrm{Cl} / \mathrm{rHCO}_{3}, r \mathrm{Cl} / \mathrm{rSO}_{4}, r \mathrm{Cl} / \mathrm{rCa}, \mathrm{rCl} / \mathrm{rMg}, \quad r \mathrm{Cl} / \mathrm{r}(\mathrm{Ca}+$ $\mathrm{Mg}), \mathrm{rCl} / \mathrm{r}(\mathrm{Na}+\mathrm{K})$.

Obteve-se assim 7 grupos de äguas cujas amostras componen tes de cada grupo são apresentadas na TABELA 21, ANEXO B.

No MAPA 16 é apresentada a distribuição espacial dos gru pos encontrados, onde podem ser notados os seguintes comporta mentos:

- as ãguas do Grupo l dominam a porção ocidental da bacia, qua se desaparecendo na porção central, voltando a aparecer na zo na mediana e no extremo leste da porção oriental da mesma;

- as ăguas do Grupo 2 ocorrem mais frequentemente a norte de Mossoro, dominando em uma faixa compreendida entre o rio Açu e o riacho da Mutuca, cedendo então lugar às äguas do Gru po 1, até o riacho do Cabelo, voltando a reaparecer na região de Parazinho;

- as äguas do Grupo 3 geralmente estão bordejando as áreas de dominio das äguas do Grupo 2; 
- as āguas dos Grupos 4, 5, 6 e 7 são águas com teores salinos e de cloro bastante elevados, crescentes no sentido dos últimos grupos (ver tambëm MAPAs 17 e 19 ).

Comparando-se o agrupamento obtido com a frequência das a nomalias nos parâmetros físicos e quimicos (QUADRO 14 item 8.2. a) pode-se notar que os resultados são bastante coinciden tes reunindo em um mesmo conjunto, poços com a mesma frequência de anomalias.

Ainda comparando-se o zoneamento dos grupos de águas com as áreas de dominância dos calcărios de alta pureza (MENOR et alii, 1980) apresentadas na FIGURA 10 (item 5.3.6), pode-se no tar uma grande coincidência entre a área de dominnio das águas do Grupo 2 com a de dominio daqueles calcärios.

\subsection{Classificação das Aguas do Aquifero Jandaira}

Com o objetivo de fornecer informações de caräter global sobre a composição quimica das āguas do aquífero Jandaíra, fo ram as mesmas classificadas em relação ao Residuo seco, à Dure za Total e aos Ions dominantes, conforme a seguir apresentado.

a) Classificasão pelo Resíduo Seco (RS)

Como os valores de Resíduo seco são bastante pröximos do Total de Sais Dissolvidos (TSD), para esta classificação foram utilizados estes dados, constantes da TABELA 10 (ANEXO B), cal culados através da equação:

$$
C E=A \cdot T S D, \text { onde }
$$

$\mathrm{CE}=$ condutividade elétrica (umho/cm) a $25^{\circ} \mathrm{C}$.

$\mathrm{A}=$ coeficiente de proporcionalidade, adotado 1,5, genericamen te para todas as amostras; e

TSD $=$ total de sólidos dissolvidos (mg/l).

Utilizando-se a classificação proposta por custödo (in \& LLAMAS, 1976, p. 1058) para os dados constantes na TABELA 10 (ANEXO B), obteve-se os resultados apresentados no QUADRO 16 a seguir. 


\begin{tabular}{|c|c|c|c|c|c|c|}
\hline \multirow{3}{*}{$\frac{\text { Tipos de Água }}{\text { Doce }}$} & \multirow{2}{*}{\multicolumn{4}{|c|}{$\begin{array}{l}\text { Limites de RS } \\
(\mathrm{mg} / 1)\end{array}$}} & \multicolumn{2}{|c|}{ Frequência } \\
\hline & & & & & $\begin{array}{l}\text { Quant.de } \\
\text { amostras }\end{array}$ & 8 \\
\hline & & & -2 & 000 & 171 & 71,2 \\
\hline Salobra & 2 & 000 & -5 & 000 & 56 & 23,3 \\
\hline Salgada & & 000 & -40 & 000 & 12 & 5,0 \\
\hline
\end{tabular}

QUADRO 16 - Classificação das äguas pelo RS (Baseada em CUSTODIO in \& LIAMAS, 1976).

Apesar da maioria das äguas ser classificada como āgua do ce segundo esses limites, pode-se notar porēm a alta frequência de àguas salobras e salgadas.

Observando-se o histograma de frequência dos valores de TSD na FIGURA 310 e QUADRO 15 (item 8.2.b) nota-se que 758 das a mostras possuem TSD compreendido entre 270,00 e $2500,00 \mathrm{mg} / \mathrm{I}$.

b) Classificacão pela Dureza Total

Com os dados constantes na TABELA 10 (ANEXO B), as águas do aquifero Jandaira, foram classificadas, segundo a Dureza Total como apresentado no QUADRO 17 a seguir:

\begin{tabular}{|c|c|c|c|}
\hline \multirow[b]{2}{*}{$\begin{array}{l}\text { Classes de } \\
\text { Ãguas }\end{array}$} & \multirow[b]{2}{*}{$\begin{array}{c}\text { Limites de Dureza Total } \\
\left(\mathrm{mg} / \mathrm{l} \text { de } \mathrm{CaCO}_{3}\right)\end{array}$} & \multicolumn{2}{|c|}{ Frequência } \\
\hline & & $\begin{array}{l}\text { Quant.de } \\
\text { amostras }\end{array}$ & 8 \\
\hline Branda & $0-50($ ou 60$)$ & 0 & 0 \\
\hline Algo Dura & $50-100$ (ou 120$)$ & 1 & 0,4 \\
\hline Dura & $100-200$ (ou 250) & 7 & 2,9 \\
\hline Muito Dura & 200 - até a saturação & 231 & 96,2 \\
\hline
\end{tabular}

QUADRO 17 - Classificação das ãguas pela Dureza Total (baseada em CUSTODIO in \& LLAMAS, 1976).

Nota-se, portanto que a quase totalidade das àguas do aqui fero Jandaira $(96,28)$ se enquadra na categoria de águas "muito duras". Como pode ser visto n a TABELA 18 (item 8.2.a), os valores variam de 85,00 até $6186,90 \mathrm{mg} / 1$ de $\mathrm{CaCO}_{3}$, com média de 989,13 
$\mathrm{mg} / 1$ de $\mathrm{CaCO}_{3}$. Estes são valores bastante altos quando compara dos aos encontrados nas äguas subterrâneas em geral (entre 10 e $300 \mathrm{mg} / 1$ de $\mathrm{CaCO}_{3}$, "apud" CUSTOdio \& LLAMAS, 1967, p. 212).

Observando-se ainda o histograma dos valores de Dureza To tal (FIGURA 3Im e QUADRO 15 item 8.2.b), pode-se notar que $75 \%$ das amostras apresentam dureza total compreendida compreen dida entre 85,00 e $1300,00 \mathrm{mg} / 1$ de $\mathrm{CaCO}_{3}$ equivalente.

c) Classificąão das äguas pelos ions dominantes

Nas TABELAS 15 e 16 (ANEXO B) são apresentadas as porcenta gens relativas e dominância dos cātions e dos ânions das amos tras analisadas. Com base nesses valores foi feita a classifica Ção das águas pelos ions dominantes, pelo sistema de SCHOELLER (SCHOELLER, 1962, "apud" CUSTOdiO \& LLAMAS, 1976).

o sistema de classificação se baseia na sobrepujança de de terminados ions sobre outros; a āgua é denominada pelo ânion (ou cátion) cuja concentração, expressa em miliequivalentes por litro, ultrapassar em $50 \%$ as suas respectivas somas. Se nenhum deles ultrapassar os 50\%, se denomina a água pelos dois ânions (ou cātions) mais abundantes. Estas últimas são denominadas "á guas mistas".

A classificação das äguas do aquỉfero Jandaỉra feita por essa sistemātica é apresentada na TABELA 22 .

A representação dessas ãguas no Diagrama de Piper pode ser vista na FIGURA $44^{\circ}$ e a sua distribuição espacial é apresentada no mapa de diagramas de stiff (MAPA 23), cuja descrição é fei ta no item (8.4.7.).

são feitas a seguir, algumas considerações relativas às di ferentes classes de ăguas.

\section{c.1) Aguas cloretadas $\left(r \mathrm{Cl}>\mathrm{rHCO}_{3} \gtrless r \mathrm{SO}_{4}\right)$}

Entre as 239 amostras analisadas, 149 delas $(62,3 \%)$ são ăguas com predominância de cloretos. Entre estas, 125 amostras $(52,3 \%)$ são àguas cloretadas e 24 amostras $(10,0 \%)$ são águas mistas, relativamente aos ânions presentes.

No que diz respeito aos cátions, entre as águas cloretadas são encontradas 23 amostras $(9,68)$ onde $r \mathrm{Na}>\mathrm{rMg} \gtrless \mathrm{rCa}, 4$ amos tras $(1,78)$ onde $\mathrm{rMg}>\mathrm{rNa} \gtrless \mathrm{rCa}, 1$ amostra $(0,48)$ onde $\mathrm{rCa}>\mathrm{rMg}$ 
TABELA 22: Classificação das ãguas pelos ions dominantes

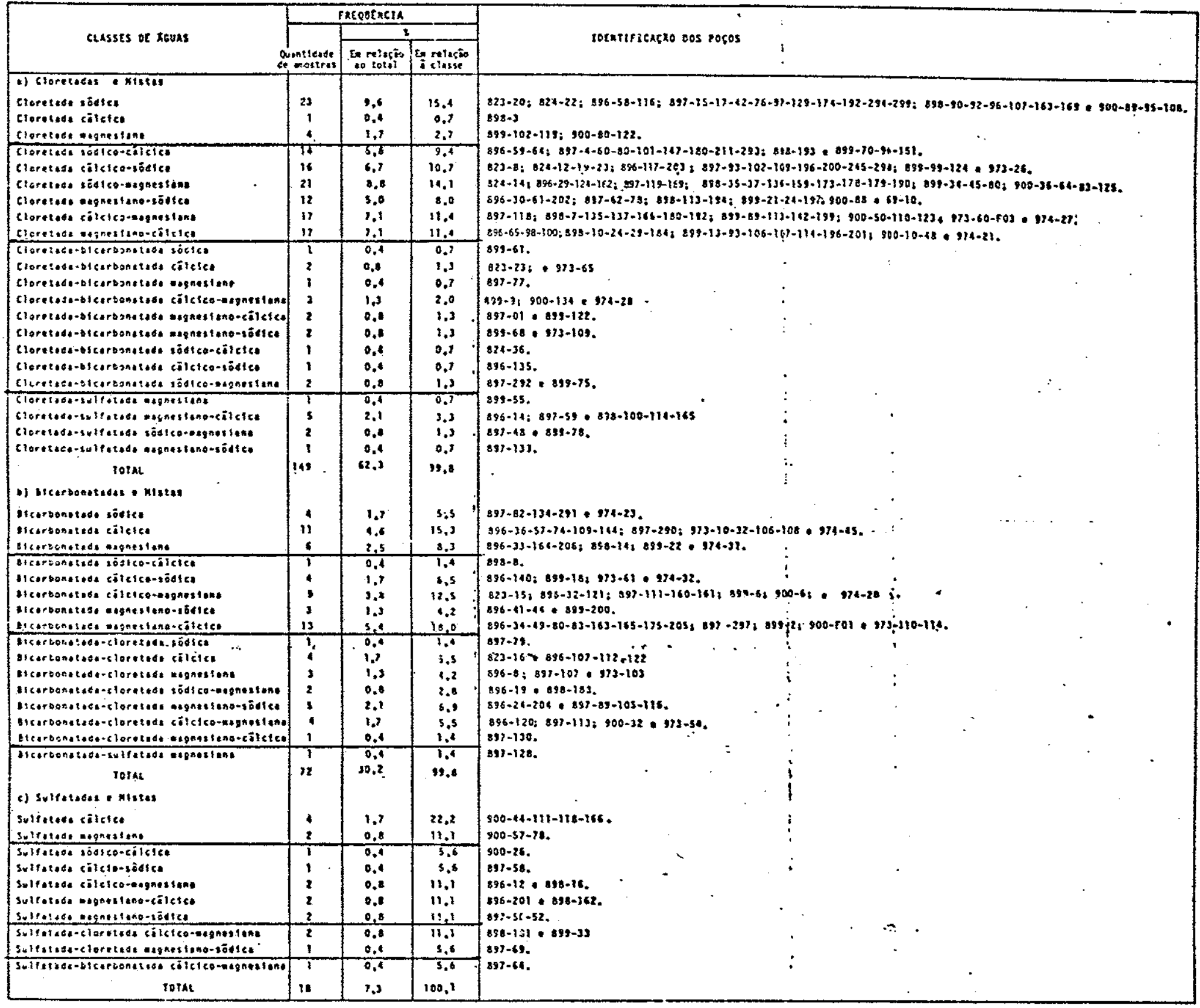


DIAGRAMA DE PIPER

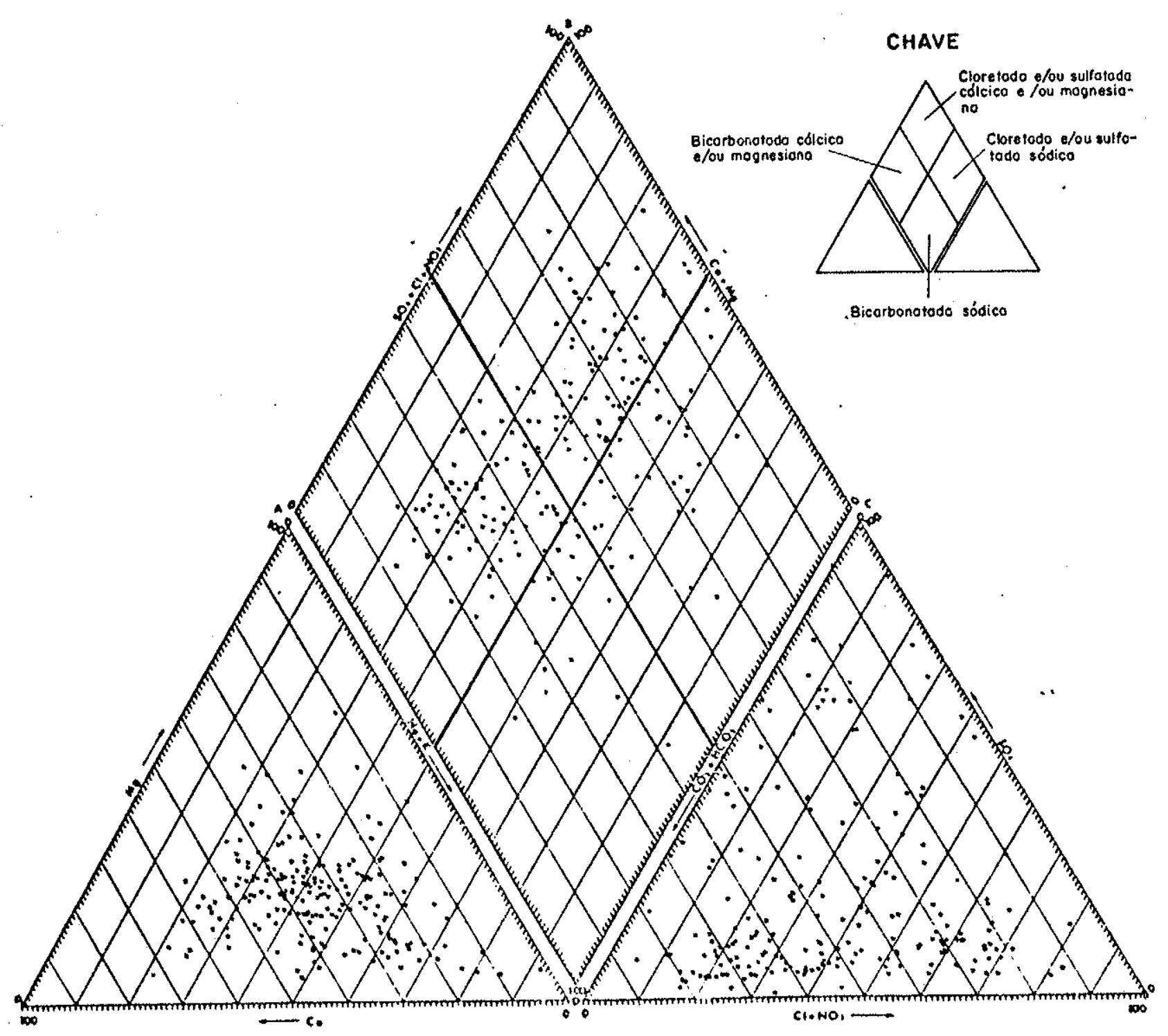

FIGURA 44 - Classificação das äguas do Aquífero Jandaíra segundo o Diagrama de Piper (teores em o meq/l. 
₹ rNa e 97 amostras $(40,5 \%)$ sem predominância de cātion especí fico, ou seja, são mistas em relação aos cátions, e podem ser representadas pela expressão genërica: $\mathrm{rNa} \gtrless \mathrm{rMg} \gtrless \mathrm{rCa}$.

c. 2) Aguas bicarbonatadas $\left(\mathrm{rHCO}_{3}>\mathrm{rCl} \gtrless \mathrm{rSO} \mathrm{S}_{4}\right)$

Entre as 239 amostras analisadas, 72 delas $(30,2 \%)$ apresen tam predominância de Íon bicarbonato; dentre estas, 51 amostras $(21,3 \%)$ são bicarbonatadas e 21 amostras $(8,8 \%)$ são ãguas mis tas em relação aos ânions.

Relativamente aos cátions presentes nas águas bicarbonata das, temos 11 amostras $(4,6 \%)$ onde $r \mathrm{Ca}>\mathrm{rNa} \gtrless \mathrm{rMg}, 6$ amostras $(2,5 \%)$ onde $\mathrm{rMg}>\mathrm{rCa} \ \mathrm{rNa}, 4$ amostras $(1,7 \%)$ onde $\mathrm{rNa}>\mathrm{rMg} \gtreqless \mathrm{rCa}$ e 30 amostras $(12,5 \%$ são mistas em relação aos cátions, ou se ja, não há predominância de cátion específico.

c. 3) Aguas sulfatadas - $\left(\mathrm{rSO}_{4}>\mathrm{rCl} \gtrless \mathrm{rHCO}_{3}\right)$

Entre as 239 amostras de águas analisadas, em 18 delas (7,3\%) há predominância do ion sulfato; dentre estas, 14 amostras $(5,8 \%)$ são sulfatadas e 4 amostras $(1,7 \%)$ são ãguas mistas relativamen te aos ânions. Deve-se notar a ausência de águas sōdicas entre as sulfatadas.

Relativamente aos cátions, entre as àguas sulfatadas temos 4 amostras $(1,7 \%)$ onde $r \mathrm{Ca}>\mathrm{rMg} \gtrless \mathrm{rNa}, 2$ amostras $(0,8 \%)$ : onde $r M g>r C a \gtrless r N a$, e 12 amostras $(5,0 \%)$ sem predominância de cátion especifico, ou seja, são mistas com relação aos cátions.

c. 4) Aguas mistas - $\left(r \mathrm{Cl} \gtrless \mathrm{rHCO}_{3} \gtrless \mathrm{rSO}_{4}\right)$

Como exposto anteriormente, são classificadas como mistas as águas em que a concentração de nenhum dos ânions, expressa em meg/1, ultrapassa em $50 \%$ a concentração dos outros ânions, apresentando portanto grande variedade de relações iônicas.

Entre as ãguas analisadas, 49 amostras $(20,58)$ são ãguas mistas em relação aos ânions, apresentando as seguintes compo sições iônicas:

- 15 amostras $(6,38)$ - cloretadas-bicarbonatadas;

- 9 amostras $(3,88)$ - cloretadas-sulfatadas;

- 20 amostras $(8,4 \%)$ - bicarbonatadas-cloretadas; 
- 1 amostra $(0,48)$ - bicarbonatada-sulfatada;

- 3 amostras $(1,28)$ - sulfatadas-cloretadas;

- I amostra $(0,4 \%)$ - sulfatada-bicarbonatada.

Na TABELA 23 estão relacionados os parâmetros estatisticos dos dados físico-quimicos, dos constituintes químicos e rela ções iônicas das águas do aquífero Jandaỉra, separados de acor do com a dominância relativa dos ânions. Através da observação dessa tabela ficam evidentes os seguintes comportamentos:

- as águas cloretadas têm os menores valores de $\mathrm{pH}$ apresentan do tanto caráter ácido como básico, ao passo que as águas bi carbonatadas e sulfatadas têm carāter básico;

- os teores salinos mais elevados correspondem às águas cloreta das, embora em termos de média de TSD as äguas sulfatadas se aproximem bastante das cloretadas;

- as águas sulfatadas apresentam os maiores valores da média de dureza total, seguidas das āguas cloretadas e bicarbonatadas, podendo-se notar que se trata essencialmente de dureza de não carbonatos;

- as médias mais elevadas de Mg e Ca são as das äguas cloretadas e sulfatadas que apresentam também praticamente os mesmos vâ lores mëdios da relação $r \mathrm{Mg} / \mathrm{rCa}$, havendo portanto equilỉbrio na participação desses íons; as ãguas bicarbonatadas, ao con trário, apesar de possuírem as menores médias de $\mathrm{Mg}$ e $\mathrm{Ca}$, a presentam maior valor médio da relação $\mathrm{rMg} / \mathrm{rCa}$, denotando pre dominio dos ions $\mathrm{Mg}$ sobre os Ions Ca nessas āguas;

- a relação $\mathrm{rK} / \mathrm{rNa}$ revela a participação praticamente equitati va desses ions em todas as äguas;

- a relação entre elementos alcalinos e alcalinos terrosos é le vemente maior nas äguas cloretadas, decrescendo para as bicar bonatadas e sulfatadas;

- nas äguas cloretadas $\mathrm{rCl} / \mathrm{xHCO}_{3}$ è exagexadamente elevada, com a mëdia atingindo 11,59 (usualmente varia entre 0,1 e 5,0).

As relações $\mathrm{rCa} / \mathrm{rCl}$, $\mathrm{rMg} / \mathrm{rCl}$ e $\mathrm{rCa}+\mathrm{rMg} / \mathrm{rCl}$, revelam, como se poderia esperar, a dominância dos Ions $\mathrm{Ca}$ e Mg nas águas sul fatadas e bicarbonatadas relativamente às cloretadas, onde domi na o Ion $\mathrm{Na}$. 

nicas para os diferentes tipos de ägua.

\begin{tabular}{|c|c|c|c|c|c|c|c|c|c|}
\hline \multirow{3}{*}{ Parâmetros } & \multicolumn{8}{|c|}{ TIXUS DF SGUA } & \multirow[b]{3}{*}{ Nedia } \\
\hline & \multicolumn{3}{|c|}{ CLORETADAS } & \multicolumn{3}{|c|}{ BICARBONATADAS } & \multicolumn{2}{|c|}{ SUIFATADAS } & \\
\hline & Mnimo & Naximo & Média & Minimo & Mäximo & Média & Mnimo & MEximo & \\
\hline 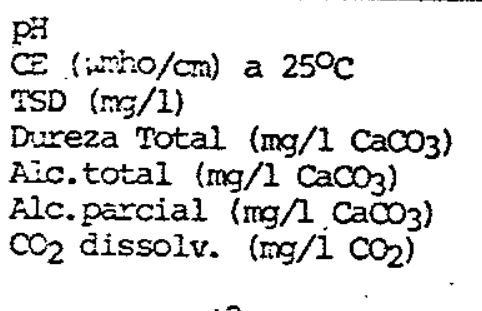 & $\begin{array}{r}6.5 \\
556.50 \\
371.00 \\
170.00 \\
16.95 \\
0.00 \\
0.37\end{array}$ & $\begin{array}{r}8.89 \\
17013.00 \\
11342.00 \\
6165.89 \\
416.00 \\
40.00 \\
58.57\end{array}$ & $\begin{array}{r}7.92 \\
3400.26 \\
2266.84 \\
1161.36 \\
237.07 \\
6.47 \\
7.74\end{array}$ & $\begin{array}{r}7.00 \\
405.39 \\
270.26 \\
35.00 \\
112.20 \\
0.00 \\
0.39\end{array}$ & $\begin{array}{r}8.89 \\
2670.89 \\
1780.59 \\
816.00 \\
720.00 \\
73.22 \\
75.64\end{array}$ & $\begin{array}{r}8.03 \\
1105.80 \\
737.20 \\
451.89 \\
343.21 \\
12.72 \\
10.46\end{array}$ & $\begin{array}{r}7.19 \\
1209.39 \\
-806.26 \\
244.00 \\
25.94 \\
0.00 \\
1.08\end{array}$ & $\begin{array}{c}8.5 \\
6451.59 \\
4301.06 \\
2952.79 \\
345.45 \\
21.53 \\
37.71\end{array}$ & $\begin{array}{r}7.76 \\
3141.86 \\
2094.57 \\
1501.54 \\
212.67 \\
4.55 \\
9.30\end{array}$ \\
\hline $\begin{array}{l}\mathrm{N}\left(\mathrm{mg} / 1 \mathrm{Mq}^{+2}\right) \\
\mathrm{Ca}(\mathrm{mg} / 1 \mathrm{Ca}+2) \\
\mathrm{Na}(\mathrm{mg} / 1 \mathrm{Na}+1) \\
\mathrm{K}\left(\mathrm{mg} / \mathrm{K} \mathrm{K}^{+?}\right) \\
\mathrm{Fe}(\mathrm{mg} / \mathrm{I} \mathrm{Fe})\end{array}$ & $\begin{array}{r}18.82 \\
22.39 \\
30.21 \\
0.97 \\
0.00\end{array}$ & $\begin{array}{r}708.50 \\
1315.19 \\
3060.29 \\
81.13 \\
3.19\end{array}$ & $\begin{array}{r}144.46 \\
237.14 \\
338.90 \\
16.44 \\
0.29\end{array}$ & $\begin{array}{r}11.00 \\
7.60 \\
19.19 \\
0.90 \\
0.00\end{array}$ & $\begin{array}{r}168.50 \\
169.02 \\
235.00 \\
124.00 \\
3.00\end{array}$ & $\begin{array}{r}56.72 \\
86.94 \\
71.03 \\
9.41 \\
0.37\end{array}$ & $\begin{array}{r}42.75 \\
112.26 \\
44.79 \\
6.00 \\
0.00\end{array}$ & $\begin{array}{r}418.17 \\
596.18 \\
500.00 \\
78.80 \\
1.44\end{array}$ & $\begin{array}{r}191.12 \\
330.97 \\
207.75 \\
27.82 \\
0.31\end{array}$ \\
\hline $\begin{array}{l}\mathrm{F}\left(\mathrm{mg} / 1 \mathrm{~F}^{-1}\right) \\
\mathrm{Cl}\left(\mathrm{mg} / 1 \mathrm{Cl}^{-1}\right) \\
\mathrm{HCO}_{3}\left(\mathrm{mg} / 1 \mathrm{HCO}_{3}{ }^{-1}\right) \\
\mathrm{SO}_{4}\left(\mathrm{mg} / 1 \mathrm{SO}_{4}^{-2}\right) \\
\mathrm{NO}_{3}\left(\mathrm{mg} / 1 \mathrm{NO}_{3}^{-1}\right) \\
\mathrm{CO}_{3}^{-2}\left(\mathrm{mg} / 2 \mathrm{CO}_{3}^{-2}\right)\end{array}$ & $\begin{array}{c}0.00 \\
106.55 \\
20.68 \\
2.1 \\
0.00 \\
0.00\end{array}$ & $\begin{array}{r}2.00 \\
7043.39 \\
507.51 \\
1380.59 \\
730.28 \\
64.25\end{array}$ & $\begin{array}{r}0.44 \\
1018.84 \\
272.20 \\
227.11 \\
37.93 \\
8.37\end{array}$ & $\begin{array}{r}0.00 \\
27.86 \\
121.65 \\
4.80 \\
0.00 \\
0.00\end{array}$ & $\begin{array}{r}3.00 \\
321.08 \\
878.39 \\
344.44 \\
143.86 \\
87.87\end{array}$ & $\begin{array}{r}0.56 \\
139.91 \\
390.77 \\
66.01 \\
14.78 \\
14.05\end{array}$ & $\begin{array}{r}0.00 \\
41.76 \\
31.65 \\
244.08 \\
0.00 \\
0.00\end{array}$ & $\begin{array}{r}0.25 \\
1130.00 \\
421.45 \\
2032.39 \\
301.53 \\
27.06\end{array}$ & $\begin{array}{r}0.03 \\
462.29 \\
250.48 \\
1153.76 \\
46.59 \\
4.40\end{array}$ \\
\hline 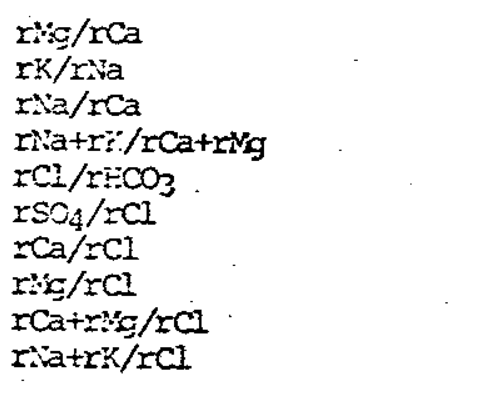 & $\begin{array}{l}0.17 \\
0.00 \\
0.25 \\
0.16 \\
1.00 \\
0.00 \\
0.16 \\
0.11 \\
0.39 \\
0.14\end{array}$ & $\begin{array}{r}4.05 \\
0.25 \\
6.78 \\
3.86 \\
289.84 \\
0.73 \\
1.45 \\
1.23 \\
2.34 \\
1.53\end{array}$ & $\begin{array}{r}1.14 \\
0.04 \\
1.39 \\
0.69 \\
11.59 \\
0.23 \\
0.49 \\
0.51 \\
1.01 \\
0.59\end{array}$ & $\begin{array}{l}0.13 \\
0.01 \\
0.21 \\
0.13 \\
0.11 \\
0.21 \\
0.07 \\
0.28 \\
0.36 \\
0.43\end{array}$ & $\begin{array}{r}8.89 \\
0.61 \\
14.78 \\
4.90 \\
1.29 \\
1.28 \\
4.90 \\
6.05 \\
9.78 \\
2.63\end{array}$ & $\begin{array}{l}1.42 \\
0.07 \\
1.06 \\
0.46 \\
0.63 \\
0.35 \\
1.29 \\
1.30 \\
2.60 \\
0.89\end{array}$ & $\begin{array}{l}0.34 \\
0.04 \\
0.10 \\
0.07 \\
0.17 \\
1.04 \\
0.56 \\
0.61 \\
1.40 \\
0.33\end{array}$ & $\begin{array}{r}2.49 \\
0.20 \\
1.32 \\
0.64 \\
39.51 \\
12.87 \\
10.63 \\
7.28 \\
17.91 \\
11.55\end{array}$ & $\begin{array}{l}1.07 \\
0.08 \\
0.60 \\
0.31 \\
5.85 \\
2.96 \\
2.16 \\
1.81 \\
3.98 \\
1.29\end{array}$ \\
\hline
\end{tabular}


8.4 Comportamento Espacial das Caracteristicas Quimicas e Fi sico-Quimicas das Aguas do Aguifero Jandaira

Com o objetivo de se proceder à análise do comportamento es pacial de alguns constituintes quimicos e indices hidrogeoquí micos das águas do aquífero Jandaỉra foram elaborados diversos mapas que são apresentados no VOLUME 2 e que, para facilidade de acesso foram relacionados sequencialmente no QUADRO 18 a se guir.

\begin{tabular}{|c|c|c|c|}
\hline Item & Título do Mapa & $\begin{array}{c}\text { Linhas de Isovalores } \\
\text { (nümeros) }\end{array}$ & $\begin{array}{l}\text { No do } \\
\text { MAPA }\end{array}$ \\
\hline 8.2.e & $\begin{array}{l}\text { Grupos de águas obtidos por } \\
\text { anālise de agrupamento }\end{array}$ & & 16 \\
\hline 8.4 .1 & $\begin{array}{l}\text { Total de sōlidos dissolvidos } \\
\text { (TSD) (mg/l) }\end{array}$ & $500,1000, \ldots, 11000$ & 17 \\
\hline 8.4 .2 & Dureza Total (mg/I de $\mathrm{CaCO}_{3}$ ) & $500,1000, \ldots, 6000$ & 18 \\
\hline 8.4 .3 & Cloretos (mg/l de $\mathrm{Cl}^{-1}$ ) & $250, \quad 500, \ldots, 6000$ & 19 \\
\hline 8.4 .4 & Sulfatos (mg/1 de $\mathrm{SO}_{4}^{-2}$ ) & $250, \quad 500, \ldots, 2000$ & 20 \\
\hline 8.4 .5 & Indices de troca de bases (ITB) & $-0,5,-0,4, \ldots, 0, \ldots, 0,8$ & 21 \\
\hline 8.4 .6 & $\begin{array}{l}\text { Capacidade de ataque qui } \\
\text { mico (Indice de Estabili } \\
\text { dade de Ryznar) }\end{array}$ & $5,0,5,5, \ldots, 8,0$ & 22 \\
\hline 8.4 .7 & Mapa com diagramas de Stiff & (diagramas) & 23 \\
\hline 8.5 .3 & $\begin{array}{l}\text { Qualidade da ăgua para ir } \\
\text { rigação }\end{array}$ & (classes) & 24 \\
\hline
\end{tabular}

QUADRO 18 - Dados gexais dos mapas hidroquímicos.

A seleção dos intervalos para o traçado das linhas de iso valores se baseou nos valores minimos e māximos de cada variá vel e na escala dos mapas apresentados. A variação espacial brus ca de alguns parâmetros no entanto motivou a distribuição bas tante irregular das isolinhas, fazendo surgir áreas de estrei tamento exagerado entre as mesmas, refletindo a heterogeneidade na composição química das äguas do aquifero.

Os mapas elaborados permitiram uma caracterização global bastante confiävel do comportamento espacial das propriedades a nalisadas. 
Algumas áreas porēm, pela ausência de poços que captam â guas no aquifero Jandaira, não puderam ser hidrogeoquimicamente caracterizadas, como é o caso, por exemplo, da área das serras do Carmo e do Mel e da área contigua às mesmas, em sua parte sudeste.

A análise dos mapas elaborados é apresentada a seguir.

\subsubsection{Mapa de total de sólidos dissolvidos (TSD)}

Existem dois aspectos a serem analisados quanto ao compor tamento das concentrações de sais no aquífero Jandaíra: a aná lise da área como um todo e a análise de parcelas dessa área que apresentam caracteristicas peculiares, cuja salinidade é de terminada por fatores locais.

Assim, analisado sob o ponto de vista global (MAPA 17) no ta-se um aumento de concentração salina em direção aos vales dos principais rios (Mossoró e Açu) e em direção ao mar. Esse comportamento, em comparando-se com o mapa piezométrico (MAPA 14) é perfeitamente concordante com a tendência natural de au mento da salinidade, de montante para jusante do fluxo subter râneo.

OS teores de TSD variam de um minimo de $270,27 \mathrm{mg} / 1$ até um mạximo de $11342,0 \mathrm{mg} / 1$ com média de $1793,0 \mathrm{mg} / 1$. Os menores teores são encontrados tanto junto às zonas de recarga do aquí fero como tambëm junto aos afloramentos do Grupo Barreiras, po rém sempre em āreas onde os gradientes hidrăulicos são mais a centuados; os maiores teores são encontrados junto à orla atlân tica, onde surgem os teores mäximos e tambēm junto ao baixo va le dos principais rios.

Dentro desse comportamento geral, algumas äreas de concen tração relativamente anômalas merecem destaque sendo descritas a seguir.

- Āreas com teores relativamente mais baixos

a) Porsão ocidental da bacia

- noroeste de Mossoró: Doço 897-291 com $386 \mathrm{mg} / 1$ e 823-16 com $539 \mathrm{mg} / \mathrm{I}$;

- sul de Maxixe: poço 896-206 com $398 \mathrm{mg} / 1$ e 896-205 com $424 \mathrm{mg} / 1$; 
- noroeste de Apodi: poço 972-106 com $496 \mathrm{mg} / 1$;

- sudeste de Gov. Dix-Sept. Rosado: poço 973-23 com $475 \mathrm{mg} / 1$.

b) Porgão central da bacia

- flanco oeste das serras do Carmo e do Mel: poço 897-64 com $806 \mathrm{mg} / \mathrm{l}$;

- flanco sul das serras do Carmo e do Mel: poço 898-113 com $980 \mathrm{mg} / \mathrm{l}$;

- vale do rio Mulungu: poço $898-8 \mathrm{com} 524 \mathrm{mg} / 1,898-183 . \mathrm{com}$ $636 \mathrm{mg} / \mathrm{l}$ e $898-14 \mathrm{com} 694 \mathrm{mg} / \mathrm{l}$.

c) Porgão oriental da bacia

- nordeste de Pureza: poço 900-6 com $281 \mathrm{mg} / 1,900-10$ com $371 \mathrm{mg} / 1$ e fonte $900 \mathrm{~F}-1 \mathrm{com} 280 \mathrm{mg} / \mathrm{l}$.

A maior parte desses núcleos está relacionàda com a presen ça de sedimentos do Grupo Barreiras. Assim por exemplo, para os poços citados que se localizam na porção oriental da bacia, a redução dos teores poderia ser explicada pela mistura com águas do aquífero Barreiras cujo teor médio de TSD em suas à guas è de $115,33 \mathrm{mg} / 1$ (QUADRO 13, item 8.2-a), associando-se o fato de que há aumento de pluviosidade à medida que nos aproxí mamos da costa leste (média de $700 \mathrm{~mm} / \mathrm{a}$ a noroeste de Pureza).

Na ārea das serras do Carmo e do Mel, embora sejam poucos os poços anômalos e possuam teores relativamente mais elevados quando comparados aos da porção oriental, foram considerados co mo tal, comparativamente aos teores dos poços circunvizinhos. O sistema aquifero Dunas-Barreiras com seu dominio parcialmente firmado sobre essas serras estaria garantindo assim uma dilui ção das águas do aquífero Jandaỉra a ele sotoposto (item 7.5.3).

Comparando-se o padrão das isolinhas com o dos outros má pas, as linhas de isovalores de TSD nessa área sugerem uma dis posição aproximadamente concêntrica, com valores crescentes ì medida que se afastam do cume dessas serras.

- Areas com teores relativamente mais elevados

a) Nücleos litorầneos

Na faixa litorânea, onde os teores normalmente já se apre 
sentam elevados por se encontrarem próximos à zona de descarga do aquifero, surgem alguns núcleos que registram teores relati vamente ainda mais elevados e que são citados a seguir:

- a sul e sudoeste da cidade de Tibau: poço 824-12 com 4224 $\mathrm{mg} / \mathrm{l} ; 824-14 \mathrm{com} 5836 \mathrm{mg} / \mathrm{l} ; 824-19 \mathrm{com} 2862 \mathrm{mg} / \mathrm{l} ; \quad 824-22$ com $11342 \mathrm{mg} / 1$ e 824-23 com $6042 \mathrm{mg} / 1$, localizados nas pro ximidades de grandes falhamentos e de lagoa intermitente interligada com o oceano;

- sudeste de Macau: poço 898-135 com $6466 \mathrm{mg} / 1$; 898-192 com $5035 \mathrm{mg} / 1$ e 898-3 com $5729 \mathrm{mg} / 1$, próximos a áreas inundá veis contíguas a salinas;

- sul de Guamaré: poço $899-89 \mathrm{com} 9010 \mathrm{mg} / 1$, junto a grande falhamento no flanco sudeste da Serra do Mangue Seco;

- a sudoeste de São Bento do Norte: poço 898-119 com $5035 \mathrm{mg} / \mathrm{l}$;

- sudeste de são Bento do Norte: poço 900-95 com $6254 \mathrm{mg} / 1$, próximo à Lagoa Cutiá;

- sudeste de Pedra Grande: poço $900-83 \mathrm{com} 4028 \mathrm{mg} / \mathrm{l}$, nas proxi midades da Lagoa Canto da Ilha de Cima, intermitente, em comunicação com o oceano.

Comparando-se este mapa com os mapas geológico (MAPA 3) piee zométrico (MAPA 14) e de contorno estrutural da base da cober tura (MAPA 11) pode-se notar que se trata de áreas assinaladas por grandes falhamentos, onde o topo dos calcários estão a co tas bastante reduzidas e as cargas piezométricas são baixas, da ordem de apenas 1 metro. Além disso, pode-se notar, observando a TABELA 13 (ANEXO B) que a relação $\mathrm{rCl} / \mathrm{rHCO}_{3}$ das águas desses poços è em geral superior a 25. Assim analisado é provável que os teores elevados de TSD estejam refletindo um processo de con taminação por água marinha que durante as marés mais altas (de cerca de $3 \mathrm{~m}$ nessa ărea) avançaria para o interior da bacia a travês de condutos de carstificação mais desenvolvidos na orla atlântica, principalmente nas zonas de intenso fraturamento (í tem 7.4.a). Observando-se o mapa poder-se-ia dizer que a iso linha de $2000 \mathrm{mg} / 1$ estaria limitando grosseiramente a zona de influência marinha. 


\section{b) Nücleos interiores}

Mais para o interior da bacia surgem também alguns núcleos de teores relativamente elevados, entre os quais se destacam:

b. a) Porcão ocidental da bacia

- em Mossoró: poço 897-15 com $4829 \mathrm{mg} / 1$;

- a noroeste de Mossoró: poço 896-162 com $6225 \mathrm{mg} / 1$, loca lizado em área com alto grau de fraturamento e correspon dente a uma das zonas preferenciais de recarga mais notó rias do aquifero, situada nas cabeceiras do Riacho Gran de, na região da Serra de Mossoró.

- oeste de Mossoró: poço 896-203 com $2597 \mathrm{mg} / 1$;

- noroeste de Gov. Dix-Sept. Rosado: poço 896-64 com 4240 $\mathrm{mg} / 1$, poço 896-12 com $3153 \mathrm{mg} / \mathrm{I}$ e 896-59 com $2670 \mathrm{mg} / 1$. Esse núcleo se localiza nas cabeceiras do riacho do Ta puio;

- a noroeste de Felipe Guerra: poço 896-30 com $3657 \mathrm{mg} / \mathrm{l}$, situado nas cabeceiras do Riacho da Forquilha.

b.b) Porgão central da bacia

- a noroeste de Carnaubais: poço 898-114 com $2534 \mathrm{mg} / \mathrm{l}$;

- a sudoeste de Carnaubais: poço 897-211 com $3816 \mathrm{mg} / 1$ e 898-96 com $3100 \mathrm{mg} / 1$, nas cabeceiras de afluente da max gem direita do riacho umbuzeiro, sobre um divisor de āguas subterrâneas pouco expressivo;

- em Carnaubais: poço 898-107 com $3333 \mathrm{mg} / \mathrm{I}$;

- sul de Alto do Rodrigues: poço 898-169 com $9540 \mathrm{mg} / 1$ e 898-162 com $2809 \mathrm{mg} / 1$;

- noroeste de Afonso Bezerra: poço 898-24 com $3710 \mathrm{mg} / 1$, nas cabeceiras do riacho da Oiticiea, e poço 898-184 com $3498 \mathrm{mg} / 1$.

b.c) Porção oriental da bacia

- norte de Afonso Bezerra: poço $899-99 \mathrm{com} 2862 \mathrm{mg} / 1$ no di. visor de águas superficiais do rio Mulungu e rio Baixa do Tamanduã;

- norte de Pedro Avelino: poço $899-70 \mathrm{com} 6254 \mathrm{mg} / 1$, cor 
respondendo ao mais elevado teor dos núcleos interiores, localizado nas cabeceiras do riacho Santa Maria;

- a sudeste de Parazinho, em Cruzamento: poço 900-36 com $4611 \mathrm{mg} / 1$, nas cabeceiras do riacho do Angico.

Comparando-se o mapa de TSD (MAPA 17) com o mapa geológico (MAPA 3) pode-se notar que os poços 897-15 da cidade de Mossoró, 898-107 em Carnaubais e 898-169 a sul de Alto do Rodrigues, con siderada a semelhança do contexto hidrogeológico, devem possuir alto teor salino por estarem nas proximidades dos aluviões dos rios Mossoró e Açu respectivamente, em äreas que devem sofrer influência marinha. Durante as marés altas a āgua do mar avança ria para o interior do continente através dos vales dos princi pais rios (MANOEL FILHO, 1970).

Analisando-se o comportamento geral das curvas de isovalo res na porção central da bacia (MAPA 17) e considerando-se as feições estruturais e topográficas da área (MAPAs 3 e 1), po der-se-ia dizer que os altos valores de TSD ao longo do vale do rio Açu, comparativamente aos do vale do rio Mulungu que só a presenta valores elevados em seu baixo curso, na região da Bai xa dos Afonsos, poderia ser explicado também como influência de āguas marinhas que, como suposto anteriormente, teriam aden trado através daquele vale, permanecendo incólumes o médio e alto vales do rio Mulungu por se encontrarema maiores altitudes. Comparando-se agora a distribuição dos nūcleos interiores (MAPA 17) com as curvas isopiezométricas (MAPA 14) e ainda com as linhas de drenagem (MAPA 2) nota-se que a maioria desses nú cleos se situa em divisores de àguas superficiais e subterrâneas e em áreas de fracos gradientes hidráulicos subterrâneos (2 x $\left.10^{-3}\right)$, portanto áreas de baixas velocidades de circulação de àguas.

Considerando-se ainda que os niveis desses poços são rela tivamente profundos (superiores a $10 \mathrm{~m}$ ) descarta-se a possibi lidade de enriquecimento em sais por evaporação da ãgua subter rânea em superfície (WHITE, 1932 "apud" TODD, 1952) e, pelo ex posto no item 8.2. d, é lỉcito então supor que as āguas de infil tração ao aportarem na porção saturada já estariam com concen trações salinas elevadas. Comparando-se o mapa de TSD (MAPA 17) 
com o mapa de solos do DNPEA (1971) nota-se que os poços de nū cleos com teores anormalmente elevados no interior da bacia es tão geralmente situados em āreas de associações de solos sali nos (poços 896-30 e 64;897-76 e 898-24), ou então em linha de đrenagem tambēm com associações de solos salinos a montante (po ç० 897-21.1).

Assim exposto, pode-se supor que devido à percolação pelos solos salinos as águas pluviais se enriqueceriam em sais, cujos teores, jā no aquifero seriam ainda aumentados devido à bai xa velocidade de circulação (baixos gradientes hidrāulicos) nes sas āreas, uma vez que os canais de circulação somente estariam em carga na época das chuvas.

Como são frequentes os indícios de formas endocārsticas e também tendo sido detectado poços secos que promovem sopro continuo e relativamente forte de vento, poder-se-ia supor ain da que a circulação de grandes volumes de ar seco e quente pe los dutos de carstificação pudessem causar uma taxa de evapora ção significativa a médias profundidades, que estariam assim corroborando com o aumento de concentração de sais em áreas de carstificação mais intensa. Não hã porém nenhum controle de pa rânetros que possa confirmar tal hipötese.

\subsubsection{Mapa de Dureza Total}

A composição quỉmica das ãguas subterrâneas è um reflexo da constituição mineralógica das rochas por onde elas percolam. - mapa de Dureza Total (MAPA 18), não foge à regra geral, refle tindo sem dúvida a natureza calcária e dolomítica das rochas da Formação Jandaĩra.

As äguas subterrâneas do aquífero Jandaỉra são predominan temente "muito duras" (item 8.3.b), apresentando valores de dü reza que variam entre um mínimo de $85,0 \mathrm{mg} / 1$, até um máximo de $6186,9 \mathrm{mg} / 1$ de $\mathrm{CaCO}_{3}$. equivalente, com média de $989,1 \mathrm{mg} / \mathrm{l}$.

A partir dos dados constantes da TABELA 10 (ANEXO B) po de-se notar que a dureza é devida principalmente a não-carbona tos.

Observa-se que a distribuição da Dureza Total (MAPA 18) se faz então geralmente com teores crescentes concordantes com o 
sentido de fluxo, ou seja, em direção aos vales dos grandes rios (Mossoró, Açu e Mulungu) e genericamente em direção ao litoral. Os valores mais baixos são encontrados no extremo leste da área, nas proximidades do contacto com os sedimentos do Grupo Bar reiras.

Dentro desse comportamento geral destacam-se alguns nücleos com teores anômalos que, como se pode notar, correspondem às mes mas āreas e geralmente tambëm aos mesmos poços notörios no mapa de TSD (MAPA 17) e de cloretos (MAPA 19). Entre essas āreas tan to na orla como no interior da bacia as mais importantes são desta cadas a seguir.

\section{- Areas com teores relativamente mais baixos}

a) Porsão ocidental da bacia

- noroeste de Mossoró: poço 897-291 com $114 \mathrm{mg} / 1$ e 897-192 com $170 \mathrm{mg} / 1$;

- oeste de Mossoró: poço 897-129 com $172 \mathrm{mg} / 1$;

b) Porcão central da bacia

- sudeste de Gov. Dix-Sept. Rosado: poço 973-23 com $150 \mathrm{mg} / 1$;

- norte de Volta: poço $897-79 \mathrm{com} 85 \mathrm{mg} / 1$;

- flanco oeste das Serras do Carmo e do Mel: poço 897-64 com $498 \mathrm{mg} / 1$;

- flanco sul das serras do Carmo e do Mel: poço 898-113 com $470 \mathrm{mg} / 1$;

- vale do rio Mulungu: poço $898-8 \mathrm{com} 194 \mathrm{mg} / 1$ :

c) Porcão oriental da bacia

- noroeste de Pureza: poço 899-6 com $166 \mathrm{mg} / 1$, poço 900-10 com $188 \mathrm{mg} / 1$ e fonte $900-01 \mathrm{com} 136 \mathrm{mg} / 1$.

Da mesma maneira que os teores de TSD, os teores de dureza parecem estar refletindo nessas áreas a influência da mistura das águas do aquífero Jandaira com as águas menos duras do aquí fero Barreiras a ele sobreposto, que apresentam Dureza Total mé dia de $43,20 \mathrm{mg} / 1$ (OUADRO 13, item $8.2-a$ ), pois esses poços se localizam nas proximidades do contato entre as formações JandaI ra e Barreiras. 
Outro fato observado é que alguns desses nücleos menos elevados coincidem com àreas de recarga do aquífero, denotando assim um processo de "endurecimento" dessas āguas no sentido do fluxo.

\section{- Areas com teores relativamente mais elevados}

a) Nücleos litorâneos

- sul e sudeste de Tibau: poço 824-22, com $4116 \mathrm{mg} / 1$, 824-23 com $3224 \mathrm{mg} / 1,824-14 \mathrm{com} 2644 \mathrm{mg} / 1$ e $824-12 \mathrm{com} 21.41 \mathrm{mg} / \mathrm{l}$;

- sudeste de Macau: poço $898-3 . \mathrm{com} 4158 \mathrm{mg} / 1,898-135$ com $4177 \mathrm{mg} / \mathrm{l}, 898-192 \mathrm{com} 3995 \mathrm{mg} / 1$ e 898-135 com $4177 \mathrm{mg} / \mathrm{l}$;

- sul de Guamaré: poço $899-89 \mathrm{com} 6187 \mathrm{mg} / \mathrm{I}$;

- sudoeste de são Bento do Norte: poço $899-119 \mathrm{com} 3244 \mathrm{mg} / \mathrm{l}$;

- sudeste de são Bento do Norte: poço 900-95 com $2552 \mathrm{mg} / 1$;

- sudeste de Pedra Grande: poço 900-83 com $2083 \mathrm{mg} / 1$.

o aumento de dureza total identificado nos poços da orla marítima pode ser explicado tambëm pela mistura de āguas mari nhas com as äguas do aquífero, através de condutos abertos pé los processos de carstificação, provavelmente desenvolvidos ao longo das zonas de falha mapeadas.

A isolinha de $1000 \mathrm{mg} / \mathrm{l}$ estaria limitando grosseiramente a ārea de influência marinha.

b) Núcleos interiores

b.a) Porsão ocidental da bacia

- a noroeste de Mossoró: poço 896-162 com $2682 \mathrm{mg} / 1$;

- Mossoró: poço 897-18 com $2004 \mathrm{mg} / 1$;

- a noroeste de Dix-Sept. Rosado: poço 896-64 com $2374 \mathrm{mg} / 1$ e 896-12 com $2371 \mathrm{mg} / 1$.

b.b) Porsão central da bacia

- Alto do Rodrigues: poço 898-162 com $2962 \mathrm{mg} / 1$ e 898-169 com $4586 \mathrm{mg} / \mathrm{l}$;

- a noroeste de Afonso Bezerra: poço 898-24 com $2431 \mathrm{mg} / 1$;

- vale do rio Mulungu: poço $898-184 \mathrm{com} 2432 \mathrm{mg} / \mathrm{l}$; 
b.c) Porgão oriental da bacia

- a norte de Pedro Avelino: poço $899-70 \mathrm{com} 3677 \mathrm{mg} / \mathrm{l}$;

- a sudeste de Parazinho: poço 900-166 com $2522 \mathrm{mg} / 1,900-44$ com $2236 \mathrm{mg} / 1,900-36 \mathrm{com} 2162 \mathrm{mg} / 1$ e 900-26 com 1056 $\mathrm{mg} / 1$.

Como já explanado anteriormente, esses poços apresentam também altos teores de cloretos, com valores da relação $\mathrm{rCl} /$ $\mathrm{rHCO}_{3}$ anormalmente elevados, evidenciando um aumento exagerado na concentração salina que parece estar ligada, à reduzida velo cidade de circulação das águas subterrâneas, associada aos tî pos de solos pelos quais percolam as águas meteöricas antes de aportarem no aquífero. Nessa passagem pelo solo, se enriquece riam em $\mathrm{Mg}$ e cederiam iNa e K (BAZILEVICH, 1965).

Pode-se notar ainda a correspondência entre os altos teo res de Dureza total e a mineralogia dos calcārios, em comparan do-se estes resultados com os mapas de distribuição de cao é Mgo (FIGURA 9 , item 5.3 .6 ) e mapa de áreas com dominância de calcários aflorantes de alta pureza (FIGURA 10, item 5.3.6). Ve rifica-se assim que os teores mais elevados de Dureza total es tão sobre āreas de dominância de rochas carbonáticomagnesianas, com $\mathrm{MgO} \geqslant 2 \%$ e os valores menos elevados, nas áreas onde $\mathrm{CaO}>$ 53 응 $\mathrm{MgO}<2$ 용.

\subsubsection{Mapa de cloretos}

Analisando-se a área como um todo (MAPA 19), observa-se que genericamente ocorre enriquecimento em cloretos de montante pa ra jusante do fluxo subterrâneo, semelhantemente ao que ocorre com a tendência de enriquecimento em sais (MAPA 17). Essa rela

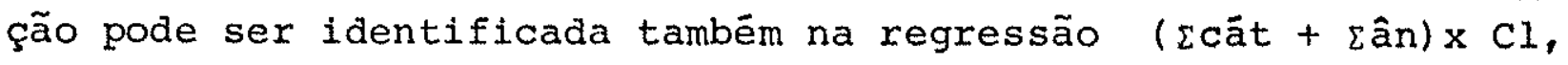
apresentada na FIGURA 38 (item 8.3.c). Assim, pode-se notar que os poços que geraram núcleos com concentrações relativamente anômalas no mapa de TSD são os mesmos dos nūcleos anômalos do mapa de cloretos.

Os teores de cloretos variam de um mínimo de $27,8 \mathrm{mg} / 1$ até um mâximo de $7043,4 \mathrm{mg} / 1$, com média de $712,1 \mathrm{mg} / 1$.

Semelhantemente ao mapa de TSD, os menores teores são en 
contrados de uma maneira geral junto às zonas de recarga do a quifero e junto aos afloramentos dos sedimentos do Grupo Bar reiras; os maiores teores se encontrando junto à orla atlântica que apresenta os teores máximos e também junto ao baixo vale dos principais rios, alēm de núcleos isolađos dispersos no do minio.

As āreas anômalas são a seguir analisadas.

\section{- Areas com teores relativamente mais baixos}

a) Porção ocidental da bacia

- a sudeste de Maxixe: poço: $896-33 \mathrm{com} 27 \mathrm{mg} / \mathrm{l}, 896-206$ com $49 \mathrm{mg} / 1,896-205 \mathrm{com} 53 \mathrm{mg} / 1$ e 896-80 com $63 \mathrm{mg} / 1$;

- a noroeste de Apodi: poço $973-32 \mathrm{com} 40 \mathrm{mg} / 1$ e 973-106 com $68 \mathrm{mg} / 1$;

- a sudeste de Gov. Dix-Sept Rosado: poço 974-23 com $48 \mathrm{mg} / 1$;

- a nordeste de Gov. Dix-Sept Rosado: poço 897-111 com $\mathrm{mg} / \mathrm{I}$;

b) Porsão central da bacia

- flanco oeste das serras do Carmo e do Mel: poço 897-64 com $130 \mathrm{mg} / 1$;

- flanco sul. das serras do Carmo e do Mel: poço 898-113 com $382 \mathrm{mg} / 1$;

- vale do río Mulungu: poço $898-14 \mathrm{com} 85 \mathrm{mg} / 1,898-8$ com $91 \mathrm{mg} / 1$.

c) Porgão oriental da bacia

- noroeste de Pureza: poço 900-6 com $36 \mathrm{mg} / 1,900-21 \mathrm{com} 41$ $\mathrm{mg} / 1$ e 900-10 com $106 \mathrm{mg} / 1$ e 900-Fl (Fonte de Pureza) com $47 \mathrm{mg} / 1$.

Quanto às provãveis causas da redução dos teores de clore tos nesses nücleos pode-se dizer que os poços das serras do Car mo e do Mel, os da porção extremo oriental da bacia e o de nor deste de Gov. Dix-Sept Rosado estariam sendo influenciados pela mistura de äguas do aquifero Barreiras superposto, que têm con centrações de cloretos menos elevadas que as do aquífero Jandaí. ra (QUADRO 13, item 8.2 a), ao passo que os poços restantes prova velmente estejam em âreas de solos relativamente menos salinos. 


\section{- Areas com teores relativamente mais altos}

a) Nücleos litorâneos

- sul e sudoeste de Tibau: poço $824-12 \mathrm{com} 2334 \mathrm{mg} / \mathrm{l}, 824-14$ com $2865 \mathrm{mg} / 1,824-22 \mathrm{com} 6613 \mathrm{mg} / 1$ e $824-23$ com $3094 \mathrm{mg} / \mathrm{l}$;

- sudeste de Macau: poço 898-135 com $3491 \mathrm{mg} / 1,898-192 \mathrm{com}$ $3675 \mathrm{mg} / \mathrm{l}$ e $898-3 \mathrm{com} 3485 \mathrm{mg} / \mathrm{l}$;

- sul de Guamaré: poço 899-89 com $5097 \mathrm{mg} / \mathrm{l}$;

- Sudoeste de São Bento do Norte: poço 899-119 com $2583 \mathrm{mg} / \mathrm{l}_{\text {; }}$

- sudeste de São Bento do Norte: poço 900-95 com $2932 \mathrm{mg} / \mathrm{l}_{\text {; e }}$

- sudeste de Pedra Grande: poço 900-83 com $2151 \mathrm{mg} / \mathrm{l}$.

b) Nücleos interiores

b. a) Poręão ocidental da bacia

- noroeste de Mossoró: poço $896-162 \mathrm{com} 3117 \mathrm{mg} / \mathrm{l}$;

- oeste de Mossoró: poço 896-203 com $1527 \mathrm{mg} / \mathrm{l}$;

- em Mossoró: poço 897-15 com $3020 \mathrm{mg} / \mathrm{I}$;

- noroeste de Gov. Dix-Sept Rosado: poço 896-64 com 1521 $\mathrm{mg} / 1$ e 896-59 com $1300 \mathrm{mg} / 1$.

b.b) Por\&ão central da bacia

- sudoeste de Carnaubais: poço 897-211 com $1876 \mathrm{mg} / 1$;

- Alto do Rodrigues: poço 898-169 com $7043 \mathrm{mg} / \mathrm{l}$; e

- noroeste de Afonso Bezerra: poço 898-24 com $1930 \mathrm{mg} / 1$.

b.c) Porção oriental da bacia

- norte de Afonso Bezerra: 899-99 com $1484 \mathrm{mg} / 1$;

- norte de Pedro Avelino: 899-70 com $3049 \mathrm{mg} / \mathrm{l}$; e

- sudeste de Parazinho: 900-36 com $2151 \mathrm{mg} / 1$.

Quanto às causas dos pontos anômalos com altos teores de cloretos poder-se-á supor as mesmas causas da existência de teo res anômalos de sais, ou seja, na orla atlântica, pelo aumento do teor de cloretos segundo o sentido do fluxo subterrâneo e também por influência de contaminação por água marinha, que por ocasião das marés altas, adentrariam no continente tanto atra vës dos vales dos grandes rios como através dos dutos de carstí ficação, desenvolvidos mais extraordinariamente junto às zonas 
fraturadas. Observando-se o mapa pode-se dizer que a isolinha de $500 \mathrm{mg} / 1$ estaria limitando grosseiramente a zona de influên cia marinha.

Os nácleos interiores, tambēm da mesma forma que no mapa de TSD, podem ser explicados pelos baixos gradientes hiaráulicos, vinculados a associações de solos salinos da cobertura dos cal cários nessas äreas.

\subsubsection{Mapa de sulfatos}

Os teores de sulfatos nas águas do aquífero Jandaira variam de $2,4 \mathrm{mg} / 1$ até $2032,40 \mathrm{mg} / 1$, com média de $250,79 \mathrm{mg} / \mathrm{I}$.

A distribuição dos teores é regular por toda a área de do minio do aquifero (MAPA 20), havendo porém alguns núcleos com teores anormalmente elevados que se destacam nesse contexto, a saber:

a) Porsão ocidental da bacia

- sudoeste de Tibau: poço $824-14 \mathrm{com} 797 \mathrm{mg} / 1$;

- noroeste de Gov. Dix-Sept Rosado: poços $896-12 \mathrm{com} 1786 \mathrm{mg} / \mathrm{l}$, 896-64 com $1271 \mathrm{mg} / 1$ e 896-201 com $1268 \mathrm{mg} / 1$; e

- flanco oeste das serras do Carmo e do Mel: poços 897-58 com: $1758 \mathrm{mg} / 1,897-52 \mathrm{com} 1320 \mathrm{mg} / 1,897-245 \mathrm{com} 1052 \mathrm{mg} / \mathrm{l}$ e 897-50 com $1115 \mathrm{mg} / 1$ :

b) Porgão central da bacia

- noroeste de Carnaubais: poço $898-114 \mathrm{com} 1047 \mathrm{mg} / 1$;

- Alto do Rodrigues: poço 898-169 com $1013 \mathrm{mg} / 1$ e 897-162 com $2032 \mathrm{mg} / 1$;

- sudeste de Pendências: poço 898-16 com $968 \mathrm{mg} / 1$, 898-181. com $1032 \mathrm{mg} / 1$ e 898-184 com $869 \mathrm{mg} / 1$.

c) Porqão oxiental da bacia

- norte de Pedro Avelino: poço $899-70$ oom $980 \mathrm{mg} / 1$;

- sudoeste de Parazinho: poço 900-111 com $854 \mathrm{mg} / 1$ e 900-118 com $807 \mathrm{mg} / 1$;

- sudeste de Parazinho: poço. 900-166 com $2025 \mathrm{mg} / \mathrm{I}, 900-78$ com $907 \mathrm{mg} / 1,900-44 \mathrm{com} 1963 \mathrm{mg} / 1$ e 900-26 com $728 \mathrm{mg} / 1$. 
A localização do nūcleo com teores elevados a noroeste de Gov. Dix-Sept Rosado deve estar associada à presença de evapo ritos (gipsita) descritos nas proximidades daquela cidade (item 5.3.6) podendo-se presumir também essa correspondência a oeste da serra do Carmo e na porção oriental da bacia, a sul de para zinho. Os teores elevados na porção central da bacia a oeste do rio Mulungu talvez sejam provocados pela presença de intrusivas básicas da Formação Macau.

Comparando-se o mapa de sulfatos (MAPA 20) com o mapa de dureza total (MAPA 18) pode-se notar uma correspondência entre os núcleos com teores elevados indicando a associação dos sul fatos com $\circ \mathrm{Mg}$.

\subsubsection{Mapa de Indices de troca de bases (ITB)}

Para a elaboração do mapa de intercâmbio iônico foi utili zado o Indice de desequilíbrio (ID) entre elementos : alcalinos e alcalinos terrosos, tambëm denominado "Indice de Troca de Ba ses - ITB", calculado de acordo com as seguintes equações:

$$
\begin{aligned}
& \operatorname{ITB}(+)=\frac{r \mathrm{Cl}-r(\mathrm{Na}+\mathrm{K})}{r \mathrm{Cl}} \\
& \operatorname{ITB}(-)=\frac{r \mathrm{Cl}-r(\mathrm{Na}+\mathrm{K})}{r\left(\mathrm{SO}_{4}+\mathrm{HCO}_{3}+\mathrm{NO}_{3}\right)}
\end{aligned}
$$

onde $\underline{r}$ significa que os teores são tomados em miliequivalentes por litro (meq/l).

Os valores assim calculados são apresentados na TABELA 14 (ANEXO B), onde os valores de ITB $(+)$ e ITB (-) foram represen tados por $I_{1}$ e $I D_{2}$, respectivamente.

A observação dos mapas de ITB (MAPA 21) e piezométrico (MA $P A$ 14) e da TABELA 14 (ANEXO B), revela que de uma maneira ge ral os valores de ITB aumentam no mesmo sentido do fluxo, por tanto em direção à costa e aos vales dos principais rios e ou tros exutörios,., enquanto que a relação $r(\mathrm{Na}+\mathrm{K}) / r(\mathrm{Mg}+\mathrm{Ca}) \mathrm{di}$ minui acentuadamente. Pode-se notar que há uma faixa continua ao longo da costa, com valores de ITB maiores do que 0,5 , que na região a oeste de Pedra Grande e Parazinho avança para o inte 
rior da bacia, que corresponde a uma das áreas de dominância de dolomitos (FIGURA 11, item 5.3.6).

Parece evidente portanto um processo de troca de bases de endurecimento das águas, ou seja, troca de elementos alcalinos ( $\mathrm{Na}$ e K) da água, por alcalinos terrosos (Ca e Mg) da rocha.Tal fato é concordante com o comportamento da dureza total (MAPA 18) que como visto, é crescente de montante para jusante do fluxo.

Valores negativos ou tendendo a zero podem ser observados ora nas proximidades de vales, ora em āreas de recarga, porēm sempre em áreas onde o gradiente hidráulico é fraco, o que pro vavelmente esteja evidenciando mudanças litológicas do meio aquí fero (maior teor de terrigenos junto aos vales).

Na parte leste da área, é visível a influência das àguas do aquifero Barreiras, conforme mostra a tendência dos valores das isolinhas, ao se tornarem mais negativos à medida que se aproximam do contato entre a Formação Barreiras e a Formação Jan daİa, evidenciando um procesșo de abrandamento das ãguas.

\subsubsection{Mapa de Indices de estabilidade do carbonato de cálcio $\underline{(I E)}$}

A capacidade de ataque químico de uma água, ou seja, o seu caráter incrustante ou agressivo (corrosivo), è um importante fator a ser considerado quando do manejo dos recursos hídricos. o grau de incrustação ou agressividade da āgua pode inviabilí zar a implantação de projetos ou aumentar sensivelmente os seus custos face à necessidade de adequá-la ao uso a que se destina, pois os processos e tecnologias de tratamento de água ou de pro teção contra a corrosão são em geral onerosos.

No presente trabalho, as águas subterrâneas do aquífero Jandaira foram classificadas de acordo com a sua tendência de ataque químico, através do Indice de Estabilidade do Carbonato de Cälcio, conforme definido por RYZNAR (1944), como expresso pela seguinte equação (ver tambēm item 8.5.4)

$$
\mathrm{IE}=2 \mathrm{pHs}-\mathrm{pH}
$$

onde:

$I E=$ Indice estabilidade do $\mathrm{CaCO}_{3}$

$\mathrm{pH}=$ Potencial hidrogeniônico da ăgua 
pHs $=\mathrm{pH}$ de saturação do $\mathrm{CaCO}_{3}$

Segundo esse autor, de uma maneira geral as äguas com indi ce (IE) maior do que 7,0 são consideradas agressivas; com valo res entre 6,0 e 7,0 têm caráter duvidoso e com valores menores do que 6,0 são incrustantes, ou seja, precipitam o carbonato de cálcio.

Assim, com base nos dados contidos na TABELA 14 (ANEXO B) foi elaborado o mapa de valores do Indice de estabilidade do carbonato de cálcio segundo RYZNAR (MAPA 22).

pode-se notar que de uma maneira geral as águas têm carā ter francamente incrustante na maior parte da área de dominio do aquifero e, conforme mostram as linhas de isovalores, geral mente estes são decrescentes no sentido do fluxo, evidenciando assim que o carāter incrustante aumenta no mesmo sentido do flu xo. Os menores valores estão localizados na porção ocidental e central da bacia, ao lado mesmo dos maiores valores.

Comparando-se o mapa piezométrico (MAPA 14) com o mapa de IE (MAPA 22) pode-se notar que genericamente os núcleos de valo res mais elevados de IE estão localizados em áreas preferenciais de recarga, havendo porēm exceções, como por exemplo a noroeste de Mossoró. Esses poços estão geralmente localizados em äreas de fracos gradientes hidráulicos e provavelmente estejam refle tindo a baixa velocidade de circulação das āguas nessas áreas. Deve-se esperar portanto, maior intensidade nos processos de carstificação nessas regiões devido ao carāter agressivo das āguas.

Nota-se também uma tendência geral de aumento de agressivi dade (IE mais elevado) à medida que os poços estejam mais próxi. mos do contacto com os sedimentos do Grupo Barreiras, como ocor re, por exemplo, nos poços 896-100, 897-50 e 60 e 898-3 e 14 nas porções ocidental e central da bacia e também nos poços 900-6 10-32 e 80, no extremo leste do dominio.

Nos poços da porção ocidental e central da bacia, o aumen to de IE é motivado pelos baixos valores da alcalinidade total, e nos poços do extremo oriental, pela redução da salinidade(TSD). (ver tambëm item $8.5,4$ ). 


\subsubsection{Mapa de diagramas de Stiff}

A análise do mapa de diagramas de stiff (MAPA 23), elabo rado com base nos dados contidos nas TABELAS 11 e 12 (ANEXO B) evidencia os seguintes aspectos:

- as águas cloretadas que representam a grande maioria, distri buem-se regularmente por toda a ärea porém, aquelas relativa mente mais concentradas em cloretos, via de regra se locali zam junto aos vales dos principais rios; no extremo noroeste da ârea estão junto à costa atlântica e na porção oriental da bacia estão preferencialmente próximas a āreas estruturalmen te falhadas;

- as águas bicarbonatadas ocorrem com distribuição regular na porção oeste da Bacia, até o vale do rio do Carmo; na porção central, surgem somente no vale do rio Mulungu e na porção 은 riental, nos arredores da cidade de Jandaira. Para leste, sua ocorrência se restringe à região da Serra verde (ărea da ser ra dos Macacos). A comparação dessas observações com o mapa litológico elaborado por MENOR et alii (1980) (FIGURA 8 ) le va a admitir que as águas bicarbonatadas estão associadas,prin cipalmente às ocorrências de calcários lajeados e compactos;

- as ocorrências de águas sulfatadas são bastante restritas, sen do encontradas em pontos đispersos na área estudada. Em a guns locais, como por exemplo, a noroeste da cidade de Gov. Dix-Sept Rosado, esse tipo de água estaria ligado à presença de evaporitos (item 5.3.6). Nesse sentido é mister destacar ainda as ocorrências de águas sulfatadas a oeste da serra do Carmo, a sudeste de Alto do Rodrigues e na área que se esten de de sudoeste a sudeste da cidade de Parazinho. 


\subsection{Qualidade das äguas do aquífero Jandaira}

\subsubsection{Introdução}

o estudo da adequação das ăguas do aquífero Jandaira tem um caráter genērico e visa, fundamentalmente, a fornecer algu mas informações para eventuais e futuros planos de aproveitamen to desses recursos para consumos básicos gerais, não se tratan do de caracterizações especificas.

Os aspectos de qualidade da água aqui analisados se refe rem às principais características químicas e físicas da àgua desse aquífero, que definem a sua adequação ao consumo humano, e aqueles considerados mais importantes, quando se pretende uti lizā-la em atividades agropecuārias e industriais.

Os aspectos de qualidade da água do aquífero Jandaíra so mente puderam ser analisados sob o ponto de vista dos paráme tros químicos e alguns parâmetros físicos das äguas amostradas, uma vez que a pesquisa de pesticidas, anālises bacteriológicas e radioativas dessas ãguas não foram solicitadas pelas entida des executoras dos estudos hidrogeológicos citados no item 8.1 .

\subsubsection{Adequação para Consumo Humano}

As caracteristicas físicas e quimicas de ãguas para consu mo humano são regulamentadas, em diversos países, através de le gislação especifica, onde geralmente são estabelecidos limites máximos desejäveis e admissiveis para cada propriedade ou cons tituinte quimico. Em geral as regulamentações são modificadas e aperfeiçoadas à međida em que as técnicas analíticas permitam que sejam estabelecidas formas mais precisas de controle de qua lidade e de determinação dos parâmetros, indices e teores dos constituintes químicos da àgua.

Para a anālise da adequação das ăguas do aquífero Jandaîra destinada ao consumo humano foram adotadas as especificações da legislação abaixo discriminada.

- Associação Brasileira de Normas Tëcnicas - ABNT: PB-19/1959;

- Resolução 25/1976 - Ministério da Saūde - CNNPA-Comissão Na cional de Normas e Padrões para Alimentos (Aguas Minerais);

- Decreto 79367 de 09/03/77. Portaria 56 BSB de 13/03/77, e 
- Organização Mundial de Saúde - OMS. 1963.

Os teores dos diferentes ions ou propriedades foram compa rados com os teores recomendados na legislação brasileira e nos casos em que a mesma se revelou deficiente foram comparados com os padrões da OMS.

Feitas essas considerações, observa-se então, com base nos dados contidos nas TABELAS 10 a 13 (ANEXO B) e nos histogramas hidro químicos (item 8.2.2) os seguintes aspectos:

- total de sais dissolvidos (TSD) - (Portaria 56 BSB de 13/3/77: valor mäximo permissivel $1000 \mathrm{mg} / \mathrm{ll}$.

Os valores de TSD foram calculados a partir da condutivida de elétrica medida em laboratório, atravēs da equação geral:

$$
\mathrm{CE}(\mu \mathrm{mho} / \mathrm{cm}) \cong 1,5 \mathrm{TSD} \text {. }
$$

Pode-se notar que das 239 amostras, 148 delas (698) ultrapassam - valor máximo permissivel de salinidade.

Deve-se salientar contudo que os teores observados em águas consumidas pela população do nordeste brasileiro são às vezes muito mais elevados que aqueles prescritos na legislação fede ral. Considerando-se a situação de carência de água nas áreas de dominio do aquífero Jandaira, nas quais a população local já está inclusive habituada ao consumo de águas de salinidade su perior a $1000 \mathrm{mg} / \mathrm{l}$ e muitas vezes a $1500 \mathrm{mg} / \mathrm{l}$, poder-se-ia ado tar este último valor como teor măximo tolerável.

- $p H$ (Resol. 25/1976: 4,0 - 9,0)

Como podemos verificar, todos os valores de $\mathrm{pH}$ (239 amos tras) estão dentro dos padrões de potabilidade admissíveis.

- Dureza Total (ABNT: máx. tolerado $200 \mathrm{mg} / 1 \mathrm{em}$ equivalen te de $\left.\mathrm{CaCo}_{3}\right)$.

Das 239 amostras analisadas, 228 delas, ou seja, 958 apre sentam dureza acima do teor máximo tolerado.

- Alcalinidade Total (OMS: permitido ate $370 \mathrm{mg} / \mathrm{l} \mathrm{em}$ equi valente $\mathrm{CaCO}_{3}$ ).

Entre as 239 amostras analisadas, 202 (848) apresentam teo res de alcalinidade inferiores ao teor permitido. 


\section{- Södio}

Embora não existam recomendações de teor máximo para sódio, esse teor fica indiretamente limitado pelo conteüdo total de só lidos dissolvidos (TSD), pois segundo o COMMTTTEE ON WATER QUA LITY CRITERIA (1972), pessoas que sofrem de hipertensão, no ca so de dietas rígidas devem consumir āguas com um māximo de 20 $\mathrm{mg} / 1$ de sódio e no caso de dietas moderadas, até no māximo 270 $\mathrm{mg} / 1$ de södio; porém, águas com teores superiores têm valor de TSD bastante elevado não sendo considerađas ãguas potäveis.

Considerando-se então a concentração máxima permitida de $270 \mathrm{mg} / 1$, de $\mathrm{Na}^{+1}$, pode-se notar que apenas 71 (30\%) das 239 amostras são insatisfatórias para consumo humano por excederem ao teor tolerävel.

- Magnésio (OMS: permitido até $50 \mathrm{mg} / 1$; excessivo $150 \mathrm{mg} / 1$ de $\mathrm{Mg}^{+2}$ ).

Nota-se que apenas 54 (23\%) das 239 amostras apresentam teo res inferiores ao permitido e 56 amostras (23\%) superiores ao teor excessivo estando portanto a maioria delas, 129 amostras (54\%) com teores entre o permitido e o excessivo.

- Cálcio (OMS: permitido até $75 \mathrm{mg} / \mathrm{l}$; excessivo $200 \mathrm{mg} / \mathrm{l}$ de $\mathrm{Ca}^{+2}$ )

Nota-se que apenas 46 (19\%) das 239 amostras apresentam teo res inferiores ao permitido e 74 amostras (31\%) superiores ao teor excessivo. A maioria delas, 119 amostras (50\%) portanto, tem teo res entre o valor permitido e o excessivo.

- Ferro total (Portaria $56 \mathrm{BSB}$ de 13/03/77: mäximo permis sivel $1,00 \mathrm{mg} / 1$ de $\mathrm{Fe}$ ).

Analisando-se os dados pode-se notar que apenas 15 (9\%) das 160 amostras apresentam teores superiores ao valor māximo permi. tido.

- Fluoretos (Portaria 56 BSB de 13/03/77: intervalo tolera do $0,6-0,8 \mathrm{mg} / 1$ de $\mathrm{F}^{-}$)

o teor recomendado de flúor em āguas para consumo humano é dependente da média das temperaturas māximas diārias do ar da região. Tendo em vista as caracteristicas climäticas da ärea 
estudada (item 4.3), pode-se admitir um teor mínimo recomenda do de $0,6 \mathrm{mg} / 1$ e mäximo de $0,8 \mathrm{mg} / 1$ (ótimo $0,7 \mathrm{mg} / 1$ ) com base na correspondência estabelecida por aquela portaria (para 26, 4 $\left.<t{ }^{\circ} \mathrm{C}<32,5\right)$. Assim posto, verifica-se então, que das 98 amos tras, 75 delas (77\%) possuem teores inferiores ao mínimo reco mendado e 19 amostras (19\%) apresentam teores superiores ao re comendado. Apenas 4 amostras (4\%) se situam dentro do intervalo desejado para teores de Flüor.

- Cloretos (Portaria 56 BSB de 13/03/77: mäximo desejável $200 \mathrm{mg} / 1$; máximo permissível $600 \mathrm{mg} / 1$ ).

Pela análise dos dados pode-se notar que apenas 71 (30\%)

das 239 amostras apresentam teores inferiores ao valor máximo desejävel; 80 amostras (33\%) apresentam teores superiores ao má ximo permissivel e $88^{\prime}$ amostras (37\%) naquele intervalo.

- Sulfato (ABNT: máximo tolerado $250 \mathrm{mg} / 1$ ).

Quanto aos sulfatos, observa-se que das 226 amostras, 62 delas (27\%) apresentam teores superiores ao teor máximo tolera do.

- Bicarbonato (OMS: permitido $300 \mathrm{mg} / 1$ de $\mathrm{HCO}_{3}^{-1}$ )

o valor de bicarbonatos permitido pela oms foi calculado a partir da alcalinidade de bicarbonatos, cujo teor permitido é de $250 \mathrm{mg} / \mathrm{l}$.

Nota-se que 123 (51\%) das 239 amostras apresentam teores de bicarbonatos superiores ao permitido.

- Carbonatos (OMS: permitido $70 \mathrm{mg} / 1$ ).

o valor de carbonatos permitido pela OMS foi calculado a partir da alcalinidade de carbonatos, cujo teor permitido é de $120 \mathrm{mg} / 1$.

Das 238 amostras apenas $1(0,4 \%)$ apresenta teor de carbo nato superior ao permitido.

- Nitratos (Portaria $56 \mathrm{BSB}$ de 13/03/77: máximo permissí vel $45 \mathrm{mg} / \mathrm{l}$ de $\mathrm{NO}_{3}^{-1}$ ).

Entre as 218 amostras analisadas, 41 delas (198) apresen tam teores supexiores ao máximo permissível, e portanto impró prias ao consumo humano. 
Teores elevados de nitrato geralmente revelam processo de poluição das águas por substâncias orgânicas nitrogenadas. Na região estudada os teores elevados de nitrato estão presentes em áreas restritas, não se tratando portanto de processo gene ralizado de poluição.

Embora alguns poços situados em centros urbanos apresentem teores de nitratos relativamente elevados, todas as amostras que excedem ao máximo permissivel correspondem a poços localizados na zona rural, nos campos de pastagem ou nas proximidades de currais. A anālise das instalações, dos perfis litológicos e dos revestimentos desses poços leva a supor os seguintes meca nismos de poluição:

- ausência de guarnecimento por tampa na boca do poço, permitin do o acesso direto às águas subterrâneas, de material orgâni co (restos vegetais, insetos e pequenos mamiferos);

- em muitos casos a boca do poço se situa no mesmo nível ou mes mo abaixo da superficie do terreno, o que permite o escoamen to de águas de superfície eventualmente ricas em matéria orgânica, para o interior do poço;

- a frequente ausência de cimentação de proteção do espaço anu lar entre a parede do furo e o revestimento de boca, favore cendo a infiltração de āguas superficiais;

- como os calcários muitas vezes permitem instalações de bombea mento em furos sem total revestimento, como se trata de meio fissurado, pode permitir o acesso rápido de águas de superfí cie eventualmente poluídas, ao nível freätico, principalmente quando estes são rasos, sem haver a desejävel eliminação natŭ ral do poluente;

- a combinação dos diferentes fatores acima citados, aliada à rápida circulação atravēs de zonas carstificadas, propiciam condições favoráveis à poluição do aquífero;

o resumo das considerações sobre a potabilidade das äguas do aquífero Jandaira considerando-se apenas os padrões extremos de potabilidade nas diferentes normas são apresentados no QUA DRO 19 a seguir. 


\begin{tabular}{|c|c|c|c|c|c|}
\hline \multirow[t]{2}{*}{ Parâmetros Considerados } & \multirow{2}{*}{$\begin{array}{l}\text { No de } \\
\text { obs. }\end{array}$} & \multicolumn{2}{|c|}{$\begin{array}{c}\text { Teores Considerados } \\
(\mathrm{mg} / \mathrm{l}) \\
\end{array}$} & \multicolumn{2}{|c|}{$\begin{array}{c}\text { Freqtência das amostras } \\
\text { em relação aos padrōes } \\
\text { (f) }\end{array}$} \\
\hline & & Mínimo Desejävel & Máximo Tolerado & Satisf. & Insatisf. \\
\hline pH & 239 & 4,0 & 9,0 & 100 & 0,0 \\
\hline Dureza Total (mg/1 de $\mathrm{CaCO}_{3}$ ) & 239 & - & 200 & 5 & 95 \\
\hline Alcalinidade Total (mg/1 de $\mathrm{CaCO}_{3}$ ) & 239 & - & 370 & 84 & 16 \\
\hline $\mathrm{Na}\left(\mathrm{mg} / 1\right.$ de $\left.\mathrm{Na}^{+1}\right)$ & 239 & - & 270 & 70 & 30 \\
\hline Magnēsio (mg/1 de $\mathrm{Mg}^{+2}$ ) & 239 & - & 150 & 77 & 23 \\
\hline Cálcio (mg/l de $\mathrm{Ca}^{+2}$ ) & 239 & - & 200 & 50 & 50 \\
\hline Ferro Total (mg/1 de Fe) & 160 & - & 1,0 & 91 & 9 \\
\hline Fluoretos (mg/l de $\left.\mathrm{F}^{-1}\right)$ & 98 & 0,6 & 0,8 & 4 & 96 * \\
\hline Cloretos $\left(\mathrm{mg} / 1\right.$ de $\left.\mathrm{Cl}^{-1}\right)$ & 239 & - & 600 & 67 & 33 \\
\hline Sulfatos (mg/1 de $\left.\mathrm{so}_{4}^{-2}\right)$ & 226 & - & 250 & 73 & 27 \\
\hline Nitratos $\left(\mathrm{mg} / 1\right.$ de $\left.\mathrm{NO}_{3}^{-\frac{1}{3}}\right)$ & 218 & - & 45 & 81 & 19 \\
\hline Bicarbonatos (mg/l de $\left.\mathrm{HCO}_{3}^{-1}\right)$ & 239 & - & 300 & 49 & 51 \\
\hline Carbonatos (mg/1 de $\mathrm{Co}_{3}^{-2}$ ) & 238 & - & 70 & 99 & 0,4 \\
\hline $\mathrm{TSD}(\mathrm{mg} / \mathrm{l})$ & 239 & - & 1000 & 38 & 62 \\
\hline
\end{tabular}

QUADRO 19 - Frequência das amostras em relação aos padrões de potabilidade. 
Pode-se facilmente notar então que, em se baseando apenas na Dureza total, onde 958 das amostras excedem ao teor tolerado, as äguas do aquífero Jandaỉra, sem tratamento prēvio, são Imprō prias ao consumo humano. Para tornä-las adequadas, seria neces särio tratamento para abrandamento das mesmas. Ainda, sob o pon to de vista das concentrações de Flũor, onde $77 \%$ das amostras apresentam teores inferiores e $19 \%$ superiores ao intervalo re comendado, seria conveniente se proceder a um controle do seu teor e efetuar tratamento para atingir o intervalo desejāvel pa ra a região, ou seja, entre 0,6 e $0,8 \mathrm{mg} / \mathrm{l}$ de $\mathrm{F}^{-1}$.

\subsubsection{Adequação para consumo agropecuärio}

\subsubsection{Adequação para consumo agrícola}

A adequação das ãguas para irrigação é determinada pela concentração de determinados constituintes especifícos tais co mo os boratos, sulfatos e cloretos e tambēm dos sais aissolví dos, correlacionáveis à condutividade elētrica, que terä seus efeitos sobre os vegetais e sobre os solos, merecendo portanto estudos detalhados inerentes a cada espécie de planta no que diz respeito à sua tolerância aos sais, ao seu ciclo de viaa, etc. , devendo-se levar tambẻm em consideração as caracteristicas cli māticas e do próprio solo, tais como a constituição mineralög ca, permeabilidade, textura, topografia e aeração.

Quase todos os tipos de ăguas que têm sido mundialmente utilizadas para irrigação, têm sua condutividade elêtrica menor do que $2250 \mu \mathrm{mho} / \mathrm{cm}$. Ocasionalmente foram usadas āguas de maior condutividade, mas salvo raras exceções, as colheitas obtidas não foram satisfatōrias. Aguas cuja condutividade elétrica vạ ria entre 750 e $2250 \mu \mathrm{mho} / \mathrm{cm}$ são comumente utilizadas obtendo-se com elas crescimento adequado das plantas, sempre que haja um bom manejo da terra e uma drenagem eficiente; no entanto as condições de salinização aparecerão se a lavagem e a drenagem dos terrenos não forem adequadas.

Em geral, äguas cuja condutividade elétrica é menor do que $750 \mu \mathrm{mho} / \mathrm{cm}$ são satisfatōxias para irrigação no que diz respei to aos sais dissolvidos, embora algumas culturas sensíveis pos sam ser afetadas adversamente mesmo quando se utilizam äguas com condutividade eletrica variando entre 250 e $750 \mu \mathrm{mho} / \mathrm{cm}$. 
No presente trabalho, para a classificação das ãguas para fins de irrigação, foi empregado o método do United States sa linity Laboratory (USSL). Esse mētodo leva em consideração a condutividade elētrica da água e a Relação de Adsorção de sōaio (RAS) .

A condutividade elétrica è dependente da concentração to tal de sais dissolvidos (item 8.3 ) e foi medida em laborató rio (TABELA 10, ANEXO B); e a RAS é calculada através da equa ção: RAS $=r N a /[r(\mathrm{Ca}+\mathrm{Mg}) / 2]^{1 / 2}$ (TABELA 14, ANEXO B).

Assim, segundo os critērios do USSL, as āguas do aquífero Jandaira foram classificadas conforme mostrado no QUADRO 20 a seguir:

\begin{tabular}{|l|c|c|}
\hline \multirow{2}{*}{ Classe } & \multicolumn{2}{|c|}{ Frequência } \\
\cline { 2 - 3 } & $\begin{array}{c}\text { Quantidade } \\
\text { de amostras }\end{array}$ \\
\hline $\mathrm{C}_{3} \mathrm{~S}_{1}$ & 124 & 52 \\
$\mathrm{C}_{4} \mathrm{~S}_{2}$ & 57 & 24 \\
$\mathrm{C}_{4} \mathrm{~S}_{1}$ & 26 & 11 \\
$\mathrm{C}_{4} \mathrm{~S}_{3}$ & 15 & 6 \\
$\mathrm{C}_{2} \mathrm{~S}_{1}$ & 12 & 5 \\
$\mathrm{C}_{4} \mathrm{~S}_{4}$ & 3 & 1 \\
$\mathrm{C}_{3} \mathrm{~S}_{2}$ & 2 & 1 \\
\hline
\end{tabular}

QUADRO 20 - Freqtência das classes de ãgua para fins de irriga
çâ.

Da observação dos valores desse quadro, pode-se verificar que a maioria das amostras (528) pertence à categoria $\mathrm{C}_{3} \mathrm{~S}_{1}$, re presentando āguas com alto risco de salinizaça e baixo risco de sódio, seguindo-se ainda um grupo expressivo (24\%) na categoria $\mathrm{C}_{4} \mathrm{~S}_{2}$, que representa riscos muito altos de salinização e risco mëdio de södio.

O QUADRO 21 , a seguir apresenta as frequências das amos tras quando considerados separadamente os riscos de salinização, avaliados atravēs dos valores de condutividade elëtrica, e dos riscos de Södio, avaliados através da Razão de Adsorção de sōdio (RAS). 


\begin{tabular}{|c|c|c|}
\hline \multirow{2}{*}{ Categorias } & \multicolumn{2}{|c|}{ Frequência } \\
\hline & $\begin{array}{l}\text { Quantidade } \\
\text { de amostras }\end{array}$ & 8 \\
\hline Salinidade & ' & \\
\hline $\mathrm{C}_{2}$ & 12 & 5 \\
\hline$C_{3}$ & 126 & 53 \\
\hline$C_{4}$ & 101 & 42 \\
\hline RAS & & \\
\hline$S_{1}$ & 162 & 68 \\
\hline $\mathbf{S}_{2}$ & 59 & 25 \\
\hline $\mathbf{S}_{3}$ & 15 & 6 \\
\hline $\mathrm{S}_{4}$ & 3 & 1 \\
\hline
\end{tabular}
QUADRO 21 - Frequência das amostras por categorias ce salinida
de e de RAS.

Observando-se os dados constantes desse quadro pode-se no tar que:

- quanto à significância das categorias da salinidade, a maio ria das äguas (53\%) se encontra dentro da categoria $\mathrm{C}_{3}$, que representa äguas de salinidade alta, podendo ser aplicadas so mente em culturas muito tolerantes aos sais e em solos com boa drenagem, devendo-se efetuar o controle de salinidade dos solos, mesmo naqueles com drenagem adequada. Segue-se a clas se $\mathrm{C}_{4}(42 \%)$ que representa äguas de salinidade muito alta, não sendo adequadas para irrigação comum. O seu uso somente ẽ aconselhável em culturas tolerantes aos sais e em solos de al ta permeabilidade e boa drenagem, devendo contudo ser utiliza da ãgua em excesso a fim de promover a lixiviação dos mesmos;

- quanto à significância das categorias de risco de sôdio,a maio ria das äguas (68\%) estä na categoria $s_{1}$, ou seja, são äguas que possuem baixa RAS, com poucas possibilidades de alcançar concentrações elevadas de södio intercambiável, podendo ser utilizadas para irrigação em quase todos os tipos de solos, atendidas porëm a sensibilidade de determinadas culturas ao 
Sódio. Segue-se depois um menor grupo $(25 \%)$ na categoria $\mathrm{S}_{2}$, que representam águas com valores mëdios de RAS, podendo apre sentar perigo quando em condiçöes deficientes de lixiviação em solos de textura fina com alta capacidade de troca de cá tions.

Assim sendo, a utilização das ãguas do aquifero Jandaíra para irrigação fica limitada, na maioria dos casos, pela cate goria de salinidade, exigindo bastante cautela na sua utili zação, devendo-se levar em consideração principalmente a re sistência das culturas aos sais, a constituição, textura e arenagem dos solos, além dos grandes volumes de ägua que de vem ser utilizados para acelerar a lixiviação. Nota-se, por outro lado, que todas as amostras apresentam valores de car bonato de sódio residual (CSR) negativos (TABELA 14, ANEXO B), indicativos da não existência de condições favoräveis à formação do carbonato de sódio, altamente prejudicial à estru tura e textura dos solos e também aos cultivos.

A distribuição espacial das classes de ãgua do aquífero Jandaíra para irrigação, conforme classificação do USSL, está representada no MAPA 24.

Da observação desse mapá pode-se depreender que:

- há nitidamente um zoneamento das áreas das classes menos sa linas para as mais salinas, crescente em direção ao mar, a partir do contacto da Formação Jandaíra com a Formação Açu, refletindo o enriquecimento em sais no sentido do fluxo sub terrâneo;

- a área de domínio das águas da classe $\mathrm{C}_{3} \mathrm{~S}_{1}$ è praticamente con tínua em todo o domínio do aquífero, com núcleos de classes de salinidade mais alta dispersos no seu interior. Exceção a esse comportamento é feita na porção oriental da Bacia, onde ocorre uma grande faixa da classe $\mathrm{C}_{4} \mathrm{~S}_{1}$ de direção NW-SE, des de sul de são Bento do Norte atē norte de. João Câmara, quebran do a continuidade da faixa $C_{3} S_{3}$ que se reinicia depois na ärea de Parazinho.

- as águas da classe $\mathrm{C}_{2} \mathrm{~S}_{1}$, menos salinas e com baixo risco de Södio se localizam no extremo oriente do dominio aa ărea es tudada, junto ao contato dos calcários Jandaíra com os sedi 
mentos do grupo Barreiras, cujas condicionantes devem ser a influência de mistura de ăguas dos dois aquíferos e indice plu u viométrico mais elevado nessa ärea (item 4.2);

- além de núcleos isolados de ăguas de classes com maior risco de salinidade e riscos de södio no interior $\left(\mathrm{C}_{4} \mathrm{~S}_{3}\right)$ e no lito ral $\left(\mathrm{C}_{4} \mathrm{~S}_{4}\right)$ nota-se um núcleo de aumento de risco em sódio $\left(\mathrm{C}_{4} \mathrm{~S}_{3}\right)$ a norte de Pedra Grande (poços 900-95 e 900-108) com alto teor em sódio, talvez por influência de águas marinhas, uma vez que a relação $r \mathrm{Cl} / \mathrm{rHCO}_{3}$ e ê relativamente alta $(15$ e 8 ; respectiva mente). O mesmo fenōmeno pode ser suposto para explicar o au mento de risco em sơdio no núcleo de Pendências.

\subsubsection{Adequação para consumo animal}

o estabelecimento de critérios de qualidade da ãgua para consumo animal é bastante complexo, não havendo até o presente, pacrões que possam ser genericamente adotados uma vez que os mesmos são influenciados pelas espécies dos animais, suas varie dades, clima, regime alimentar, sexo, condicionamento físico, etc. Em muitos países as experiências ainda prosseguem com o objetivo de se determinar os "limites aceitāveis" dos consti tuintes quimicos das ăguas para dessedentação animal.

Segundo LOGAN (1965) de uma maneira geral o gado deve con sumir ägua com menos de $5000 \mathrm{mg} / 1$ de sais dissolvidos (TSD). Na falta de uma classificação universal das ăguas para consumo ani mal, foi utilizada a do Estado de Montana (EEUU) que parece ser apropriada para uso geral (LOGAN, op. cit.). Segundo esses pa arões as āguas do aquífero Jandaira são classificadas conforme consta no QUADRO 22 a seguir.

\begin{tabular}{|l|c|c|c|}
\hline \multirow{2}{*}{ Classe } & TSD (mgtl) & $\begin{array}{c}\text { Quantidade } \\
\text { de amostras }\end{array}$ & 8 \\
\hline Boa & & 179 & 75 \\
Satisfatōria & atē 2500 & 29 & 12 \\
Pobre & 2500 até 3500 & 16 & 7 \\
Insatisfatöria & 3500 até 4500 & 15 & 6 \\
\hline
\end{tabular}

QUADRO 22 - Classificação das äguas para consumo animal 
Observa-se assim que apesar dos elevados teores de TSD, a maioria das amostras (75\%) se classifica como boa para consumo animal e apenas uma pequena parcela delas (6\%) è insatisfatória.

Segundo LOGAN (1965) diz-se que o gado do nordeste do Bra sil bebe muito bem água com concentração de $42000 \mathrm{mg} / \mathrm{l}$ de sais. Segundo o COMMITEE ON WATER QUALITY CRITERIA (1972) há muitas Indicações de que o gado não se desenvolve a contento quando se dessedenta com ägua de alto teor salino. Assim sendo, mesmo as águas da classe "insatisfatória" poderiam ser apenas excepcional mente utilizadas para dessedentação animal.

\subsubsection{Adequação para consumo industrial}

A adequação das águas para fins industriais é bastante com plexa, uma vez que depende do tipo de indüstria e dos processos de industrialização utilizados. Esses fatores fazem com que se ja considerada uma variedade muito ampla de constituintes quí micos e aspectos físico-químicos da água para suprimento das indústrias. Por outro lado, tēcnicas modernas de tratamento de ăgua permitem que praticamente qualquer tipo de ăgua possa ser tratada para adquirir as características desejăveis para um de terminado uso. Os custos desse tratamento porém serão tanto mais elevados quanto maiores as diferenças entre as caracterís ticas da ăgua de suprimento e as recomendadas para utilização no processo industrial especifico. De uma maneira geral o cus to do tratamento das äguas representa apenas uma pequena parce la do custo final dos produtos, tornando-se geralmente viáveis mesmo os processos mais onerosos de tratamento.

Na TABELA 24 (ANEXO B) são apresentados diversos tipos de in dústrias $e$ os teores limites de alguns constituintes presentes nas äguas normalmente adotados pelas mesmas.

Da comparação dos teores constantes da TABELA 10, ANEXO B, com os teores-padrão constantes da TABELA 24 do mesmo anexo onde se destacam marcadamente os teores excessivos de TSD e de Dureza total, depreende-se que as äguas do aquifero Jandaira não podem ser utilizadas para fins industriais em seu estado na tural, exigindo para tanto, tratamentos prëvios.

Dentre as diversas propriedades que devem ser analisadas nas äguas que se destinam a fins industriais, encontra-se a capa 
cidade de ataque químico, que revela o seu caräter incrustante, neutro ou agressivo (corrosivo). Sob este aspecto a TABELA 14 , ANEXO B, apresenta os valores do indice de estabilidade do car bonato de cālcio, conforme definido por RYZNAR (1944) que forne ce indicações sobre a capacidade de ataque químico das äguas em condições naturais.

- Indice de estabilidade do carbonato de cālcio (IE) foi definido por Ryznar, pela expressão:

$$
I E=2 \mathrm{pHs}-\mathrm{pH} \text {, onde: }
$$

IE - Indice de estabilidade do carbonato de cālcio;

pH - potencial hidrogeniónico da ăgua em consideração;

pHs - potencial hidrogeniônico de saturação teōrica (pH de satu ração ou $\mathrm{pH}$ de equilíbrio do carbonato de cálcio).

- Indice de estabilidade do carbonato de cälcio conforme definido por Ryznar pode ainda ser calculado através da expres são: $I E=S-C-p H$, onde $S$ e $C$ são obtidos a partir de ábacos, pois $S$ é função da concentração total de sais dissolvidos (TSD) e $C$ é função da alcalinidade total e da concentração do íon cã cio.

No QUADRO 23 a seguir, são apresentadas as frequências das águas amostradas segundo o valor do IE, classificadas conforme proposição de Custódio (in __ \& LLAMAS, 1976 p. 1765), baseado em Ryznar, 1944).

\begin{tabular}{|c|c|c|c|c|}
\hline & & & Freqt & \\
\hline . & & & $\begin{array}{l}\text { Quantidade } \\
\text { de amostras }\end{array}$ & 8 \\
\hline 4,0 & $-5,0$ & muito incrustante & 7 & 3 \\
\hline 5,0 & $-6,0$ & $\begin{array}{l}\text { moderadamente in- } \\
\text { crustante }\end{array}$ & 96 & 40 \\
\hline 6,0 & $-7,0$ & $\begin{array}{l}\text { pouco incrustante } \\
\text { ou agressiva }\end{array}$ & 107 & 45 \\
\hline 7,0 & $-7,5$ & agressiva & 17 & 7 \\
\hline 7,5 & $-9,0$ & $\begin{array}{l}\text { francamente agressi } \\
\text { va }\end{array}$ & 11 & 4 \\
\hline$>$ & 9,0 & muito agressiva & 1 & 0,4 \\
\hline
\end{tabular}

QUADRO 23 - Frequência do carāter das ãguas em relação aos valores do Indice de estabilidade do carbonato de cálcio (IE). 
Como se pode observar, a maior parte das amostras (458), apresenta um. carāter anfōtero, ou seja, pode ser incrustante ou agressiva dependentemente das condições de utilização da mesma onde a temperatura ë uma variävel importante. Segue-se em impor tância, com a frequência de $40 \%$, a categoria "moderadamente in crustante". Nota-se assim que praticamente o caräter incrustan te, com uma porcentagem total de $88 \%$, sobrepuja o caráter agres sivo, com 11,48 .

Assim sendo, pode-se prever que as äguas do aquifero Jan daira, ao serem aduzidas por canalizações, possam provocar a precipitação de carbonato de cälcio e portanto cuidados espe ciais devem ser tomados quando da utilização dessas äguas, prin cipalmente no que concerne aos usos em caldeiras e produção de vapor.

o comportamento espacial das äguas do aquífero Jandairra no que se refere ao seu caráter incrustante ou agressivo pode ser observado no mapa de IE (MAPA 22), cuja descrição foi apresen tada no item 8.4.6.

Além desses aspectos, em ãguas para destinação industrial deve-se considerar ainda o conteúdo de sillica, fosfatos, gās sulfíarico, oxigênio dissolvido, manganês, etc. porēm, geralmen te tais constituintes somente são analisados dependentemente do interesse em um determinado uso da ăgua em processos indus triais especificos, não tendo sido pesquisados, conforme reve lam os laudos das análises utilizados nesta monografia. 


\section{SITUACÃO ATUAL DA CAPTACÃO NO AQUIFERO JANDAIRA}

\subsection{Introducão}

Para a avaliação da captação e explotação atual das ãguas do aquifero Jandaíra foram utilizados os dados constantes do In ventärio do IPT (IPT, 1982) por se tratar do mais recente ca dastramento realizado abrangendo a quase totalidade da área de dominio do aquifero.

A grande extensão de domínio do aquífero Jandaira e a faci lidade de acesso ao aquífero, por ser ele do tipo freātico e portanto acessivel atravēs de poços escavados (cacimbas) e po ços tubulares relativamente rasos, cuja perfuração pode ser fei ta por processo percussivo, proporcionam a existência de um gran de nümero de obras de captação das suas ãguas, quer seja aträ vés de poços tubulares, quer seja atravēs de cacimbas e fontes. Para a avaliação aqui apresentada porēm, foram utilizadas ape nas as informações sobre pơ̧os tubulares.

Dos 1300 poços tubulares no Estado do Rio Grande do Norte até 1979 cadastrados pelo IPT (IPT, 1982) contou-se com 853 poços $(65,68)$ construídos para captação de ăgua do aquífero Jandaíra (FIGURA 45). Infelizmente uma parcela razoável desses poços não dispõe de dados técnicos e informações completas, dificultando os levantamentos e anālises feitas e que são apresentados nos itens que se seguem.

\subsection{Evolução das Captacões no Aquífero Jandaíra}

Com o objetivo de avaliar a tendência de aproveitamento das águas do aquífero Jandaíra, procedeu-se a um levantamento da quantidade de poços tubulares anualmente construídos. Dos poços cadastrados, $70 \%$ possuíam informações sobre 0 ano da sua cons trução. A evolução das perfurações no periodo 1918 atẻ 1979 es tá representada na FIGURA 46 a seguir.

Pode-se observar que atë 1930 praticamente não houve acrēs cimos no ritmo das perfurações. Provavelmente tal fato tenha si do motivado tanto pela pequena demanda de ägua como pela falta de conhecimento hidrogeológico e estrutura inadequada das enti dades perfuradoras, pela deficiente organização técnico-administrativa e equipe tēcnica. De 1930 atē 1965 houve um pequeno in 


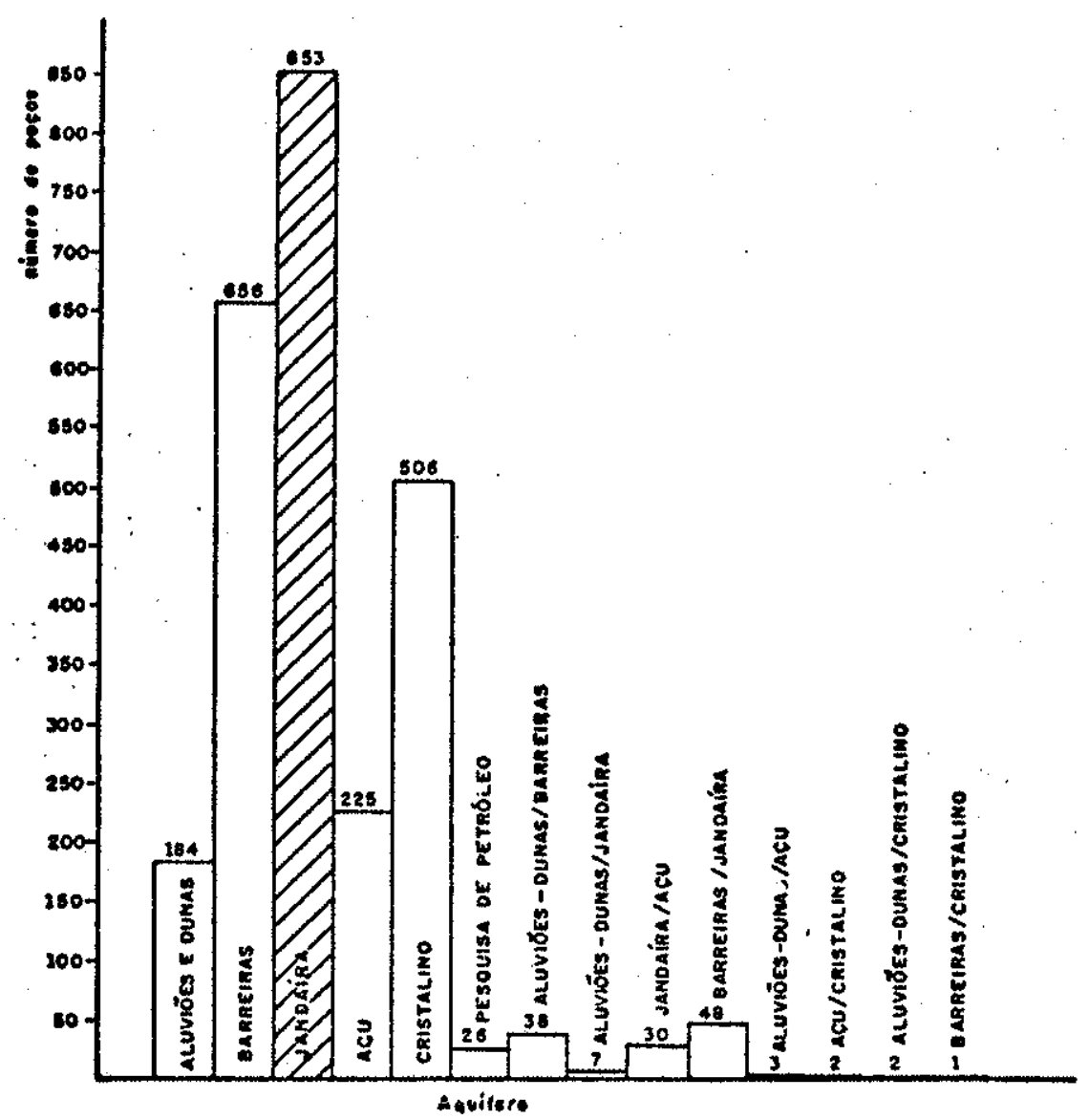

FIGURA 45 - Poços construídos no Estado do Rio Grande do Norte no período de 1918/79 segundo os aquíferos (IPT, 1982).

cremento, praticamente nitido apenas no aquifero Jandaira e que a partir de 1942 já é visivel para todos os aquíferos daquele Estado. A partir de 1964 porém se torna notório o grande aumen to no ritmo das perfurações que mantëm essa tendência até o fi nal do periodo analisado. Verifica-se também que a partix de 1970, com exceção do aquífero Açu, os aquíferos Jandaíra, Bar reiras e Cristalino apresentam praticamente a mesma taxa de au mento anual. Esse fenômeno talvez possa ser explicado pela ação de dois fatores essenciais: o aumento natural da demanda e os investimentos públicos (federais e estaduais) e privados no se tor, facilitados então pela atuação da SUDENE. Alēm desses fato res, presume-se que o avanço no conhecimento hidrogeológico da região e o aprimoramento das técnicas de perfuração tenham con tribuído tambēm para despertar maior interesse na utilização das águas subterrâneas. 


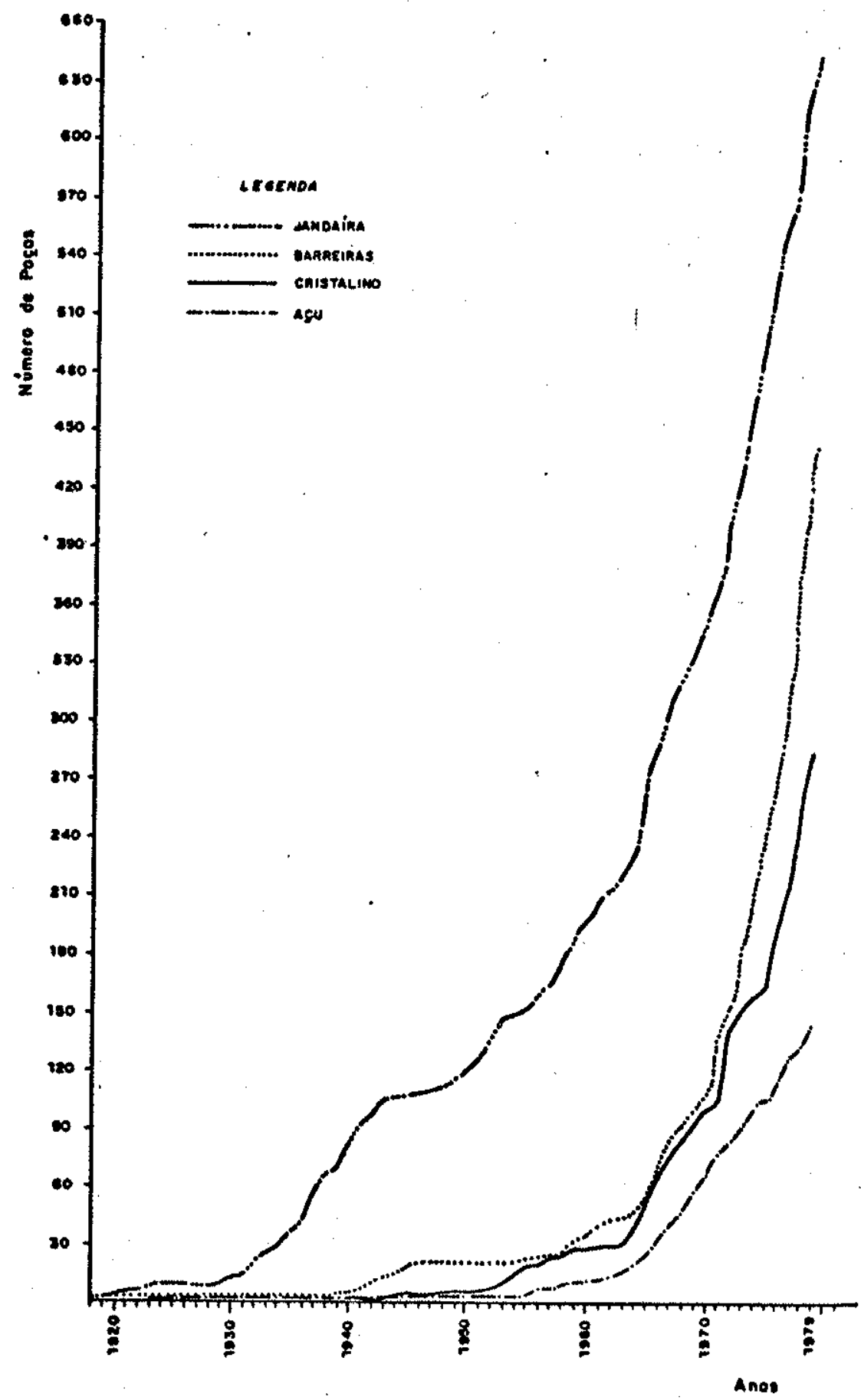

FIGURA 46 - Evolução da construção de poços tubulares no Estado do Rio Grande do Norte no período $1918 / 79$, segundo os aquiferos (IPT, 1982).

Observa-se ainda que esses impactos parecem atuar defasada mente segundo os aquíferos, pois nota-se na FIGURA 46 que o incremento surge primeiramente no aquífero Jandaíra, seguido 
ordenadamente pelos aquiferos Barreiras, Cristalino e Açu. Os fatores que causam essa antecedência do aquífero Jandaíra prova velmente sejam a sua extensa ārea, o clima semi-ärido em seu domínio com praticamente inexistência de outra alternativa de abastecimento, e a maior facilidade de construção de obras de captação. Tais fatores sobrepujam mesmo a alta densidade demo grāfica, no caso da ārea de domínio do aquífero Barreiras (a bai xa densidade demogräfica na área do aquífero cristalinol e as dificuldades técnicas e econômicas de acesso ao aquífero Açu.

Na FIGURA 47 a seguir estã representada a evolução da cons trução de poços conforme as iniciativas privada e püblica no pe ríodo 1918/1979 naquele Estado.

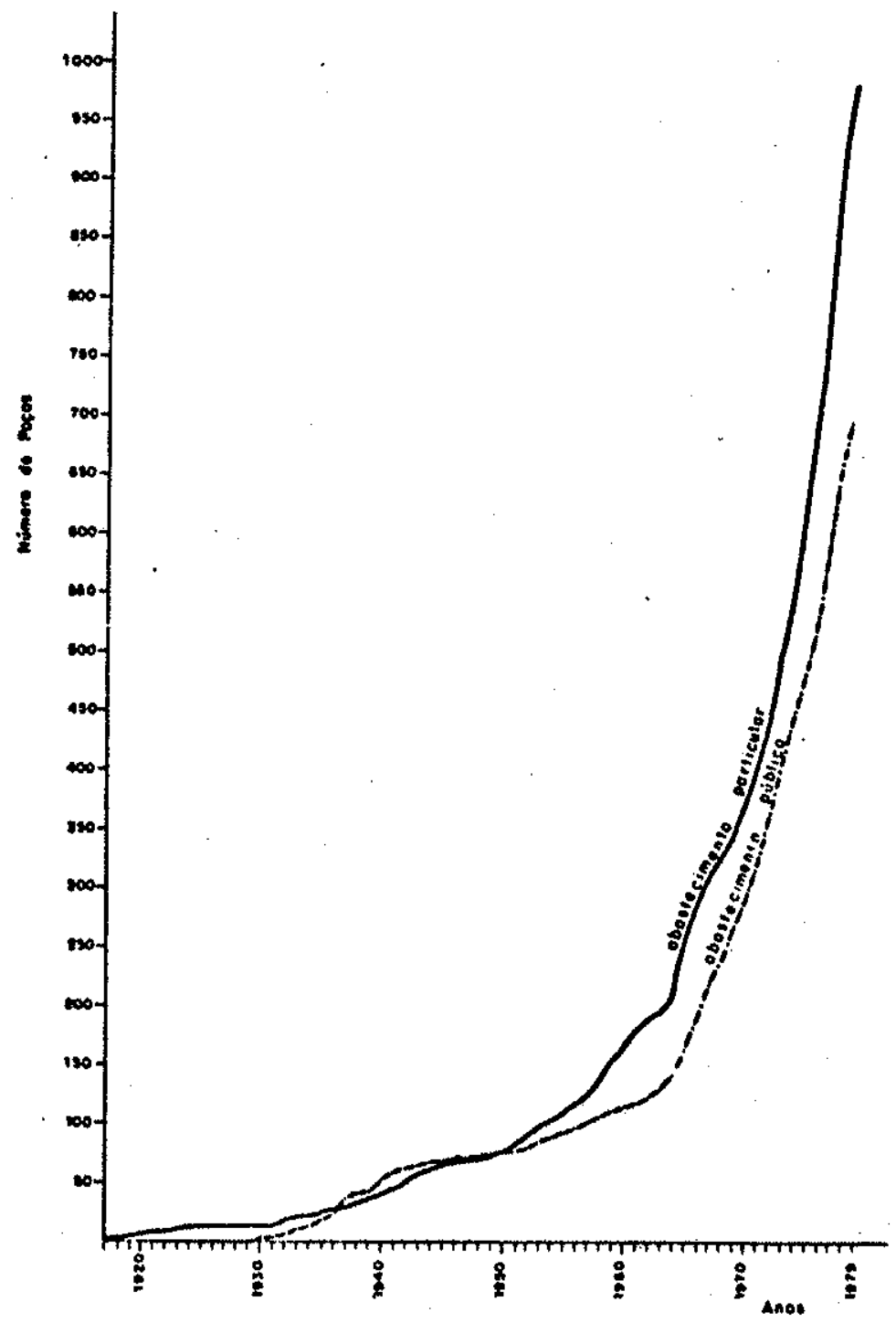

FIGURA 47 - Evolução da construção de poços tubulares no Estado do Rio Grande do Norte, no periodo 1918/79, conforme iniciativas particular ou püblica (IPT, 1982). 
Pode-se notar que a partir de 1970 praticamente ambas as iniciativas têm tido as mesmas taxas de incremento anual e que a iniciativa püblica sobrepujou a particular apenas no periodo 1935/50, correspondente provavelmente às medidas governamentais de combate à forte estiagem que se abateu sobre o nordeste no início da dëcada de 1930 .

Na FIGURA 48 estão representados ainda os poços construí dos até 1979 no Estado do Rio Grande do Norte, segundo o aquífe ro captado, conforme seja de iniciativa privada ou püblica.

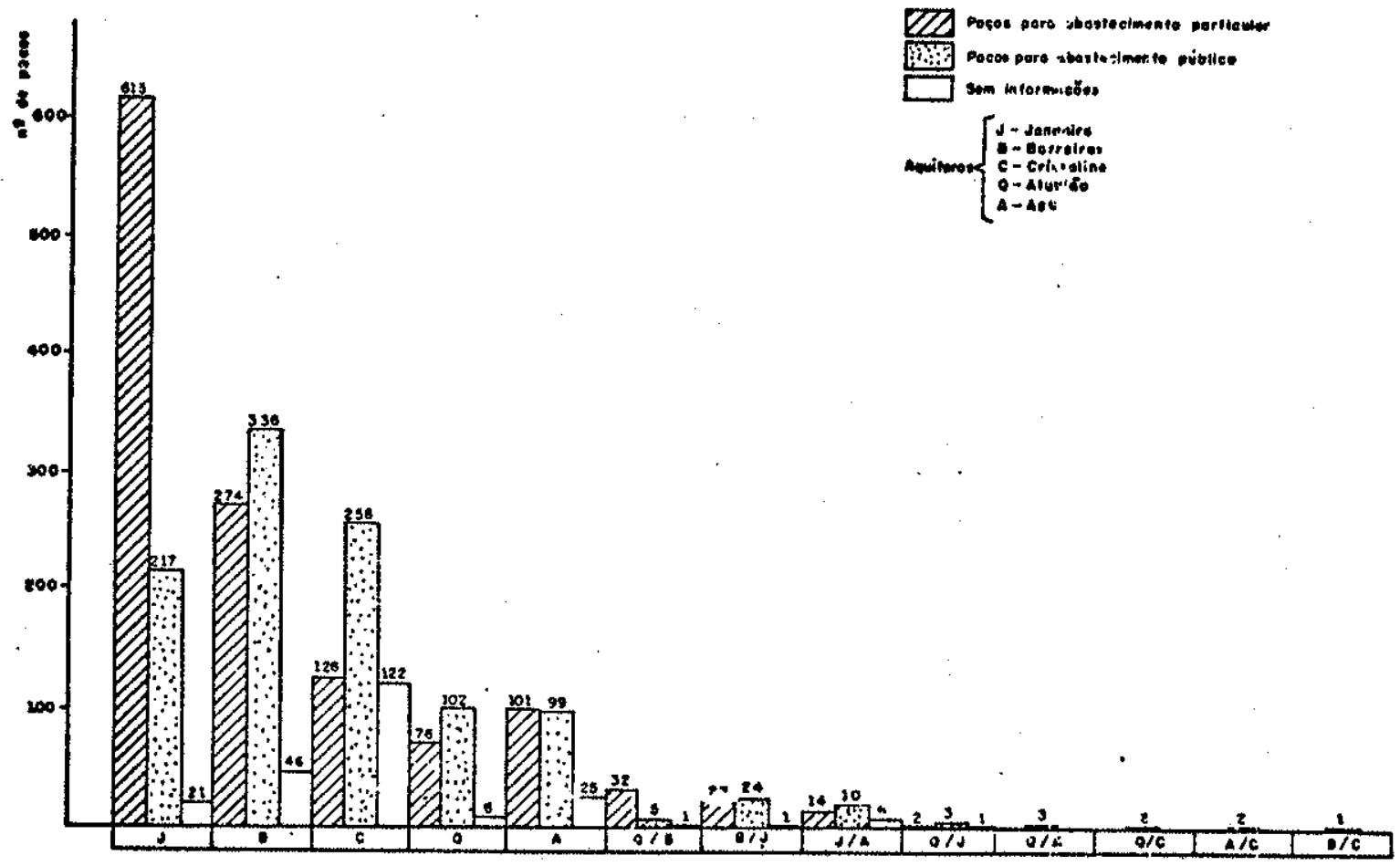

FIGURA 48 - Poços construídos atē 1979 no Estado do Rio Grande do Norte, por aquifero, segundo as iniciativas particular ou pública (IPT, 1982).

Verificamse que no caso do aquífero Jandaira, .615 poços (72\%) entre os cadastrados são de propriedade particular e que, apenas no caso deste aquífero ocorre uma predominância de poços para abastecimento particular; nos aquíferos Barreiras e Crista lino ocorre o inverso, e no aquífero Açu essas iniciativas se igualam. 


\subsection{Caracteristicas Construtivas dos Pocos Tubulares}

A quase totalidade dos poços para captação das ãguas. do aquífero Jandaíra apresenta diâmetro útil de 6 polegadas, são perfurados pelo sistema percussivo a cabo e recebem revestimen to de 6 polegadas muitas vezes apenas nos primeiros $10 \mathrm{~m}$ sendo despre vidos de revestimento nas porções inferiores. Conforme informa ções obtidas durante o cadastramento, uma das causas de abando no de poços reside no colapso de trechos das paredes não reves tidas.

Dos 853 poços que captam āgua no aquifero Jandaira no Estą do do Rio Grande do Norte 705 deles $(82,6 \%)$ possuíam dados de profundidade. A FIGURA 49 representa $\circ$ histograma de frequências das profundidades dos poços analisados.

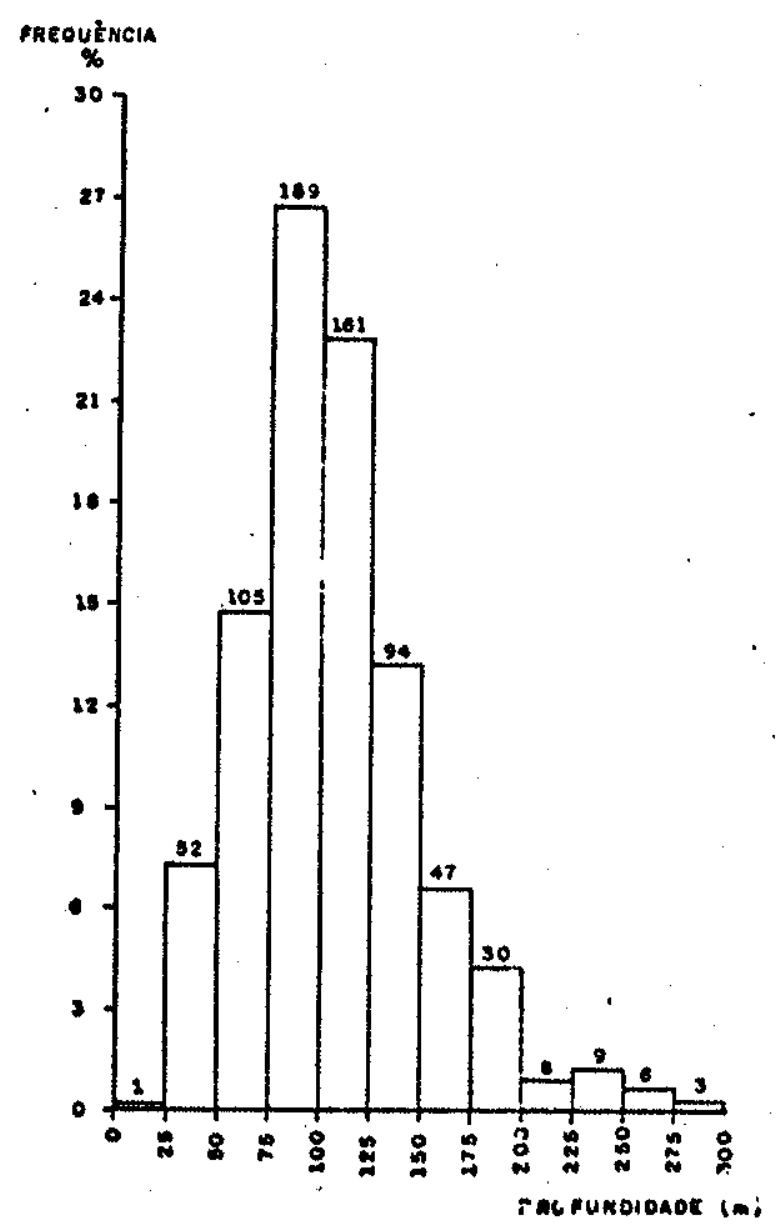

FIGURA 49 - Histograma de frequências das profundidades dos poços 
Observando-se o histograma pode-se notar que as profundida des variam de 25 atē 300 metros; a maior freqtência, 189 poços $(26,8 \%)$ é correspondente ao intervalo $75-100 \mathrm{~m}$; a grande maio ria porém $(77,8 \%)$ possui profundidades que variam entre 50-150 m.

\subsection{Equipamentos de Bombeamento}

Ainda com os dados obtidos no cadastramento efetuado pelo IPT foram levantadas informações sobre os equipamentos utiliza dos para explotação das ãguas do aquífero Jandaira, bem como ob tida a vazão mëdia de produção para cada tipo de equipamento. Nessa avaliação não foram consideradas as captações mistas. Dos 853 poços desse aquífero, 555 (65\%) estavam equipados na ocasião da quele cadastramento. O QUADRO 24 a seguir fornece as informa ções obtidas.

\begin{tabular}{|c|c|c|c|}
\hline \multirow{2}{*}{ Equipamento } & \multicolumn{2}{|c|}{ Frequência dos Poços } & \multirow{2}{*}{$\begin{array}{c}\text { Vazão Mëdia } \\
m^{3} / h\end{array}$} \\
\hline & Quant. & 8 & \\
\hline Catavento & 185 & $3.3 ; 3$ & 0,8 \\
\hline Compressor (sistema air lift) & 120 & 21,6 & 6,0 \\
\hline Bomba injetora & 95 & 17,1 & 6,0 \\
\hline Bomba pistão (tipo Itaūna) & 81 & 14,4 & 2,0 \\
\hline Bomba manual & 56 & 10,1 & 0,8 \\
\hline Bomba submersivel & 18 & 3,2 & 5,0 \\
\hline
\end{tabular}

QUADRO 24 - Equipamentos de bombeamento utilizados nos poços do aquífero Jandaíra.

Os sistemas de bombeamento mais utilizados para explotação consistem no catavento $(33,3 \%)$ e "air lift" $(21,6 \%)$, principal mente devido à falta de rede de distribuição de energia elētri ca na ārea de dominio do aquífero e mesmo devido à própria fina lidade de uso da àgua, onde a maioria dos poços destina-se à agropecuāria, sendo grande parte deles construidos no prōprio local de consumo, às vezes de difícil acesso e de elevado cus to para instalação de rede elëtrica.

\subsection{Estado Atual dos Pocos Tubulares}

Com o objetivo de avaliar a situação atual das captações 
em termos de potencialidade de explotação, foram tratadas ainda as informações levantadas durante a inventariação processada pe 10 IPT (IPT, 1982).

Nas FIGURAS $50 \mathrm{a}$ e b está representado o estado atual dos poços cadastrados. Pode-se verificar que, em 1979, sem conside rar as captações mistas, apenas 529 poços $(62,0 \%)$ se encontra vam em operação; 158 poços $(18,5 \%)$ foram abandonados; 77 poços (98) ainda não tinham recebido equipamentos de bombeamento na ocasião do cadastramento e 59 poços $(6,9 \%)$ haviam sido desativa dos, não obstante fossem utilizăveis.

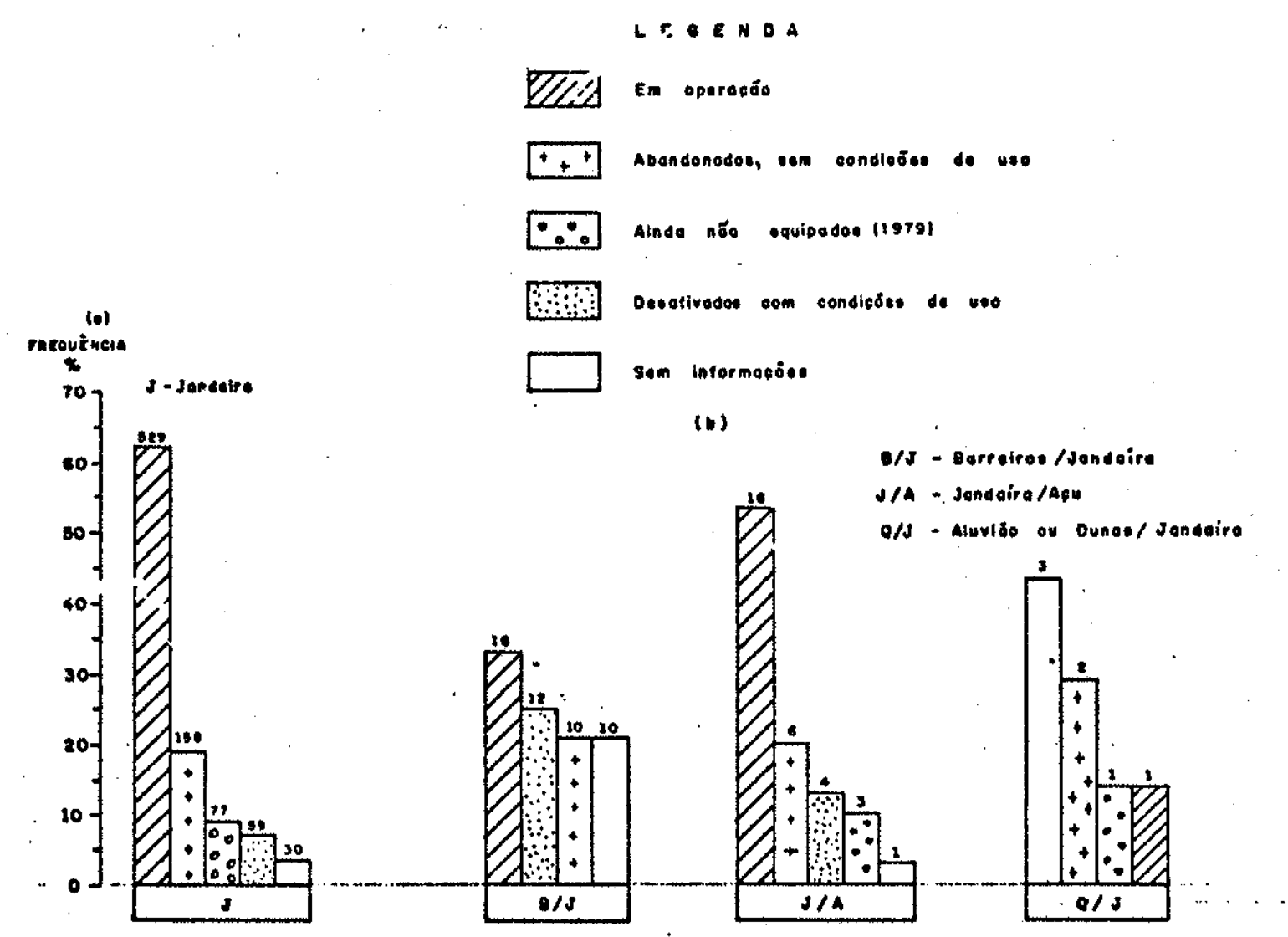

FIGURA 50 - Estado atual dos poços do aquifero Jandaíra (a) e mistos (b), no Estado do Rio Grande do Norte (IPT, 1982, modificado). 
No caso dos poços abandonados, as principais causas de abandono foram a baixa produção e os desmoronamentos das pare des do furo e menos frequentemente pelo alto teor salino das äguas produzidas. . Foram incluídos como "sem informações" , os poços onde, quando da execução do cadastramento "in situ", não foi possivel obter informações que permitissem prever a sua rea tivação ou seja, se a paralisação era temporária ou abandono definitivo. Estes, num total de 30 poços, atingem uma razão de $3,5 \%$.

9.6 Volume de Aguas Explotadas

Segundo o cadastramento efetuado, dos 853 poços que captam água no aquífero Jandaíra, $726(85,1 \%)$ possuíam dados de vazão. A FIGURA 51 apresenta a freqtência das vazões desses poços.

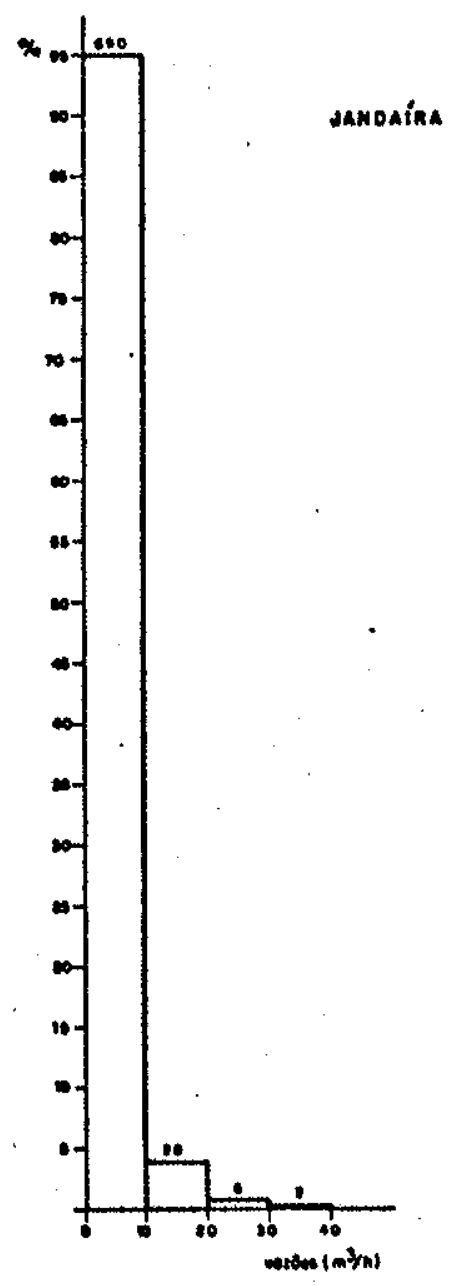

FIGURA 51 - Histograma de frequências dos valores de vazão 
Nota-se que as vazões variam de $\underline{0}$ até $40 \mathrm{~m}^{3} / \mathrm{h}$, pórém a grande maioria 690 poços (958) apresentam vazões que variam de o até $10 \mathrm{~m}^{3} / \mathrm{h}$.

Considerando-se as informações sobre o periodo de funciona mento dos poços em operação durante o ano de 1979 e as vazões de explotação medidas durante o cadastramento ou as vazões de ensaios de produção desses poços, foram calculados os volumes explotados em cada poço durante aquele ano, obtendo-se um volu me total de $3,6.10^{6} \mathrm{~m}^{3}$.

Não existem dados relativos ao volume de água explotado em anos anteriores, mas a evolução das perfurações referida ante riormente (FIGURA 46) deve se refletir tambēm no volume de āgua explotado. Assim sendo, é possivel concluir que houve um aumen to anual considerāvel na explotação de āgua subterrânea do aquí fero Jandaira nos ültimos 10 ou 15 anos e que essa tendência continuará de forma ainđa mais acentuada no futuro.

\subsection{Usos da Agua}

A destinação da ãgua explotada do aquífero Jandaíra foi ana Iisada tambēm a partir do levantamento efetuado pelo IPT.

Há muita dificuldade em definir a destinação específica das ăguas explotadas uma vez que em grande parte dos poços a ăgua è utilizada para os mais diversos fins, tendo sido despre zadas as suas limitações de adequação baseadas em parâmetros le gais; a pertinência da área ao polígono das secas e as dificul dades de obtenção de água de melhor qualidade premem sua utili zação para os mais diversos fins. O QUADRO 25 apresenta as fina lidades das perfurações e os volumes explotados, em termos de usos da àgua. 


\begin{tabular}{|c|c|c|c|c|}
\hline \multirow{2}{*}{ Usos } & \multicolumn{2}{|c|}{ Freqthência de poços } & \multicolumn{2}{|c|}{$\begin{array}{l}\text { Volumes explotados } \\
\left(\times 10^{3} \mathrm{~m}^{3} / \mathrm{a}\right) \\
\end{array}$} \\
\hline & Quant. & 8 & Quant. & 8 \\
\hline $\begin{array}{l}\text { PD-AN: Particular doméstico e } \\
\text { animal }\end{array}$ & 190 & 37,4 & 1304 & 36,64 \\
\hline AP: Abastecimento püblico & 128 & 25,2 & 820 & 23,05 \\
\hline AG: Agropecuārio & 120 & 23,6 & 814 & 22,87 \\
\hline PD: Particular doméstio & 60 & 11,8 & 488 & 13,72 \\
\hline $\begin{array}{l}\text { PD-IR: Particular domēstico e } \\
\text { irrigação }\end{array}$ & . 4 & 0,79 & 43 & 1,2 \\
\hline ID: Industrial & 4 & 0,79 & 55 & 1,5 \\
\hline $\mathrm{RE}:$ Recreação & 2 & 0,39 & 35 & 0,9 \\
\hline TOTAL & 508 & 99,97 & 3559 & 99,88 \\
\hline
\end{tabular}

QUADRO 25- Frequência dós poços e volumes explotados segundo os usos da água.

Verifica-se assim que a maioria dos poços construídos tem fins mültiplos, onde se sobressaem os usos doméstico. e animal, com 190 poços $(37,4 \%)$; os usos especificos sendo limitados a um reduzido número de poços. Quanto aos poços colocados na catego ria de abastecimento püblico deve-se ressaltar que têm tambēm usos mültiplos abrangendo praticamente todos os tipos de uso aqui considerados.

E notöria a grande quantidade de captações para fins agro pecuārios (dessedentação animal e irrigação), com 120 poços ... $(23,6$ 왕).

No que diz respeito à destinação dos volumes explotados po de-se verificar que mantêm as mesmas relações dos objetivos dos poços, ou seja, com a maior porcentagem referida ao uso particu lar domëstico e animal. A componente de consumo animal, conquan to não pudesse ser avaliada especificamente, deve ser bastante expressiva uma vez que participa das três categorias de maiores volumes apresentadas no QUADRO 25 . 


\subsection{Introdução}

o custo de produção de água subterrânea analisado em con junto com outros aspectos, tais como as reservas aquiferas e a qualidade quimica da água, complementa o quadro geral de diagnós tico da explotação atual dos recursos do aquifero Jandaira, for necendo ao usuârio os elementos básicos necessários a uma defí nição quanto ao seu aproveitamento. Cumpre ressaltar contudo, que os custos apresentados devem ser considerados dentro dos $1 \underline{1}$ mites das condições aqui impostas, constituindo-se portanto ape nas como simples referência quanđo da elaboração de programas e projetos de abastecimento devendo ser portanto, ajustados às con dições especificas de cada plano.

\subsection{Metodologia de Avaliacão}

Na avaliação dos custos de produção de ãgua devem ser con sideradas diferentes sistemáticas, de acordo com os fins a que se destinam as águas explotadas. Assim, por exemplo, as demandas de àgua para abastecimento público e dessedentação animal geral mente variam pouco no decorrer do ano, comparativamente às de mandas de ăgua para fins de irrigação, que oscilam bastante em função do tipo e estágio da cultura, da época do ano, tipo de solo, etc.

Além dos fatores de demanda, a estimativa do custo de pro dução do metro cúbico de água subterrânea requer inicialmente a definição das caracteristicas tēcnicas da obra de captação.

Para esta avaliação foram definidos os poços-padrão do aquífero Jandaira, para os quais consideram-se vālidos os cálcu los efetuados.Devido à grande heterogeneidade litológica e hi drodinâmica do aquifero, e conseqtentemente da impraticabilidade de se estabelecerem āreas típicas, os poços-padrão foram de finidos em função das caracteristicas geomētricas e hidrăulicas médias, estimadas ou calculadas estatisticamente (itens $7.3 \mathrm{e}$ 9.3), tendo então sido definidos três tipos de poços-padrão, cu jas características tēcnicas são apresentadas no QUADRO 26 a se guir. 


\begin{tabular}{|c|c|c|c|c|c|c|c|c|c|}
\hline \multirow{2}{*}{$\begin{array}{l}\text { Poço } \\
\text { TÍpo }\end{array}$} & \multicolumn{2}{|c|}{ Perfuração } & \multicolumn{2}{|c|}{ Revestimento } & \multirow{2}{*}{$\begin{array}{c}\text { Vazäo } \\
\text { especifica } \\
\left(\mathrm{m}^{3} / \mathrm{n} / \mathrm{l}\right)\end{array}$} & \multirow{2}{*}{$\begin{array}{l}\text { Vazäo de } \\
\text { Projeto } \\
\left(\mathrm{m}^{3} / \mathrm{h}\right)\end{array}$} & \multirow{2}{*}{$\begin{array}{c}\text { Nivel } \\
\text { Dinâmi oo } \\
\text { (m) }\end{array}$} & \multirow{2}{*}{$\begin{array}{l}\text { Rebal xam, } \\
\text { acumulado } \\
20 \text { anos } \\
\text { (m) }\end{array}$} & \multirow{2}{*}{$\begin{array}{c}\text { Altura } \\
\text { Mancoútrica } \\
\text { (H) } \\
\text { (m) }\end{array}$} \\
\hline & $\overbrace{(\text { polegadas) }}^{\varnothing}$ & $\begin{array}{l}\text { Profund. } \\
\text { (m) }\end{array}$ & $\begin{array}{c}\text { T'o P.V.S. } \\
\text { (pol.) }\end{array}$ & 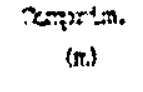 & & & & & \\
\hline \multirow{2}{*}{ PI } & 8 & $0-10$ & \multirow{2}{*}{6} & \multirow{2}{*}{$\begin{array}{c}102 \\
18 \mathrm{~m} \text { filtros }\end{array}$} & \multirow{2}{*}{0,5} & \multirow{2}{*}{5,0} & \multirow{2}{*}{50,0} & \multirow{2}{*}{18,0} & \multirow[b]{2}{*}{68,0} \\
\hline & 6 & $10-120$ & & & & & & & \\
\hline \multirow{2}{*}{ P2 } & 8 & $0-10$ & \multirow{2}{*}{6} & \multirow{2}{*}{$\begin{array}{c}102 \\
18 \mathrm{~m} \text { filtros }\end{array}$} & \multirow{2}{*}{2,5} & \multirow{2}{*}{10,0} & \multirow{2}{*}{30,0} & \multirow{2}{*}{$-3,0$} & \multirow{2}{*}{33,0} \\
\hline & 6 & $10=120$ & & & & & & & \\
\hline \multirow{2}{*}{23} & 8 & $0-10$ & \multirow{2}{*}{6} & \multirow{2}{*}{$\begin{array}{c}102 \\
18 \mathrm{~m} \text { filtro: }\end{array}$} & \multirow{2}{*}{5,0} & \multirow{2}{*}{30,0} & \multirow{2}{*}{20.0} & \multirow{2}{*}{2,0} & \multirow[b]{2}{*}{22,0} \\
\hline & 6 & $10-120$ & & & & & & & \\
\hline
\end{tabular}

QUADRO 26 - Características tēcnicas dos poços-padrão do aquífe ro Jandaíra.

\subsection{Estimativas de Custos}

Considerando-se que o maior volume das äguas explotadas do aquifero Jandaira se destina ao abastecimento humano e animal, foram avaliados apenas os custos de produção do metro cúbı̇co de àgua para esses fins.

Com base nas características tēcnicas dos poços-padrão fo ram calculados:

A - Despesas com construção do poço e casa de bombas;

B - Despesas com aquisição, transporte e instalação do equipa mento de bombeamento;

C - Despesas com operação e manutenção; e

D - Despesas com consumo de energia elētrica 


\section{A - Despesas com construção do poço e casa de bombas}

a) Despesas de construgäo do po\&o

Na avaliação dos gastos com construção do poço foram compu tados os seguintes custos parciais:

- elaboração do projeto e supervisão técnica da construção da obra;

- deslocamento e instalação da perfuratriz e acessórios;

- abertura do furo, tendo-se admitido perfuração pelo método per cussivo a cabo;

- acabamento da obra, tendo sido considerado revestimento em PVC de 6" e filtros tipo "Nold".

- operações de limpeza, cimentação e desinfecção;

- ensaios e análises, "tendo-se considerado a realização de um en saio de produção ( 18 de bombeamento e $24 \mathrm{~h}$ de recuperação) e ainda anālise física, química e bacteriolögica de uma amos tra de ägua.

o custo final de cada poço-padrão, ou seja, o custo do po co perfurado, revestido e testado, pronto para receber o equi pamento de bombeamento fol avaliado tomando-se os preços mé. dios de janeiro/84, tendo-se obtido o valor abaixo, uma vez que as características construtivas são as mesmas para os três po ços-padrão:

Valor orçado: $\operatorname{Cr} \$ 13300.000,00$

b) Despesas de construção da casa de bombas

Considerou-se a construção da casa de bombas para abrigo do quadro de comando e eventuais equipamentos e acessórios, em alvenaria, com área construída de $4 \mathrm{~m}^{2}$. Tomando-se o valor de Cr\$ $100000,00 / \mathrm{m}^{2}$ (janeiro/84), temos:

Valor orçado: Cr $\$ 400000,00$

Admite-se a vida ütil das obras como sendo de 20 anos.
B - Despesas com aquisição, transporte e instalação do equipa mento de bombeamento

Foram consideradas as despesas relativas à aquisição, trans 
porte e instalação do equipamento de bombeamento.

a) Aquisiqão

Os preços das bombas variam em função da vazão que se dese ja produzir e da altura de recalque (altura manométrica) cor respondente. Para a avaliação das despesas com equipamentos fo ram consideradas as características dos projetos constantes do QUADRO 26 e as condições a seguir relacionadas:

- utilização de bomba elétrica submersivel, selecionada em fun ção das alturas de recalque e das vazões a bombear;

- preço médio da bomba a partir de preços informados por dife rentes fornecedores para o conjunto motor-bomba, quadro de co mando, cabos elétricos e tubulação de descarga (janeiro/84);

Preço: $\operatorname{Cr} \$ 1000 \quad 000,00$

- a vida ütil do equipamento de bombeamento sendo de 7 anos e a vida útil da obra de 20 anos, pode-se prever aquisição de três equipamentos de bombeamento, que deverão ser adquiridos a ca da 7 anos.

Para a avaliação do custo de produção da àgua porēm, foi computado o montante das despesas em aquisição e instalação dos três equipamentos de bombeamento.

b) Transporte e instalação

Para a instalação, considerou-se energia elētrica disponi vel no local do poço e não necessidade de transformadores, ten do-se admitido então que as despesas com transporte e instala ção dos equipamentos sejam correspondentes a $25 \%$ do seu valor de compra.

Assim sendo, o capital dispendido para fazer frente às des pesas integrantes do item $B$, será:

Valor orçado: $\operatorname{Cr} \$ 1250000,00$

c - Despesas com operação e manutenção

a) operação

Para a estimativa das despesas anuais com mão-de-obra for am 
consideradas as seguintes condições:

- regime de bombeamento de $12 \mathrm{~h} / \mathrm{d} ; 30 \mathrm{~d} / \mathrm{mês} ; 12$ meses/ano:

- admitindo-se esse regime de bombeamento, serão necessários dois operadores do sistema, porēm, para reduzir os custos, con siderar-se-á que os dols operadores são responsāveis pela ope ração e manutenção de uma bateria de 5 poços;

- salārio mensal correspondente a dois salärios mínimos da re gião, ou seja: $\operatorname{Cr} \$ 100$ 000,00/mês (janeiro/1984). Este salạ rio deverá ser acrescido dos encargos sociais (INPS, FGTS e Seguro de Acidente de Trabalho) num montante de cerca de $35 \%$ e também do 13 s salärio.

b) Manutensão

Considerou-se, para a avaliação das despesas anuais com ma nutenção, que os gastos com reparos, reposição de peças, compra de lubrificantes (óleos e graxas), etc., como sendo anualmente da ordem de $5 \%$ do preço do equipamento de bombeamento.

D. - Despesas com consumo de energia elëtrica

a) Consumo

- consumo de energia elétrica è calculado com base no tra balho mecânico necessārio para elevar $1 \mathrm{~m}^{3}$ de água à altura de 1 metro. Assim teremos:

$$
C_{E}=0,002726 \times \frac{\mathrm{V} \cdot \mathrm{H}}{r_{\mathrm{mb}}}
$$

onde:

$\mathrm{C}_{\mathrm{E}}=$ consumo anual de energia (kWh);

$\mathrm{V}$ = volume anual de àgua bombeada;

$\mathrm{H}$ = altura manomētrica (altura de recalque) (m);

$r_{\mathrm{mb}}=$ rendimento do conjunto motor-bomba, admitido em 658 .

b) Despesa

$$
D_{E}=C_{E} \times p
$$

onde:

$D_{E}=$ despesa anual com energia elëtrica (Cr\$); 
$C_{E}=$ consumo anual de energia $(k W h) ;$

$\mathrm{p}$. = preço do $\mathrm{kWh}$ para companhias estatais de ägua e esgoto. Cr\$43,35 em janeiro/84.

Avaliação do custo de producão do $\mathrm{m}^{3}$ de âgua

Com o objetivo de tornar realista a avaliação do custo de produção converteu-se os valores de cruzeiros em oRTNs. Nestas condições, em qualquer cálculo efetuado, os valores jã estarão corrigidos monetariamente, o que dispensa cálculos do custo de financiamento para cobrir as despesas referentes aos itens A, B e $c$.

As despesas relativas aos itens $A$ e $B$ foram diluidas duran te a vida util mëdia das obras e equipamentos, com a finalidade de Iinearizar o custo nesse periodo.

são relacionados a seguir os valores das despesas envolvi das nos câlculos efetuados, conforme as condições admitidas.
A - a) Construção do poço:
Cr\$ $13300.000,00$
b) Construção da casa de bombas:
Cr $\$ \quad 400 \quad 000,00$

B - a) aquisição dos 3 equipamentos de bambeamento: Cr\$3000 000,00

b) transporte e instalação dos equipamentos de bombeamento.

Subtotal

$\frac{\operatorname{Cr} \$ \quad 750 \quad 000,00}{\operatorname{Cr} \$ 17 \quad 450.000,00}$

Valor correspondente à parcela anual do custo
(1/20 do subtotal) :
Cr $\$ 872.500,00$
c - a) operação: - mão-de-obra:
Cr\$ 691200,00
b) manutenção:
Cr\$ $\quad 62 \quad 500,00$
subtotal
Cr\$ $1626 \quad 200,00$

Valor anual de custo comum: Cr\$ $1626.200,00$

o custo de produção do $\mathrm{m}^{3}$ de água à boca do poço fol calcu lado atravēs da seguinte expressão:

$$
C_{p}=\frac{((A+B+C) / 20)+D}{V} \text {, onde: }
$$


$c_{p}$ - custo anual de produção do $\mathrm{m}^{3}$ de água (cr $\left.\$\right)$
A - despesas com construção do poço e casa de bombas; ·
B - despesas com aquisição, transporte e instalação do equipa- mento de bombeamento;
C ..- despesa anual de operação e manutenção do sistema;
D - despesa anual com energia elétrica;
$V$ - Volume anual de água explotada por poço, sendo de 21.600 $\mathrm{m}^{3} / \mathrm{a}, 43.200 \mathrm{~m}^{3} / \mathrm{a}$ e $129.600 \mathrm{~m}^{3} / \mathrm{a}$ para os poços padrão $\mathrm{P}_{1}$, $\mathrm{P}_{2}$ e $\mathrm{P}_{3}$, respectivamente.

Na TABELA 25 são apresentados resumidamente os valores envolví dos nos cálculos e os custos de produção do $\mathrm{m}^{3}$ de àgua em cada poço-padrão.

Comparando-se os valores dessa tabela pode-se notar que pa ra poços pouco produtivos (poço-padrão $P_{1}$ ) os custos são mais elevados.

Os custos de produção de água do aquifero Jandaira quando comparados com o dos aquíferos Açu e Barreiras (IPT, 1982) tam bém à boca do poço e nas situações mais desfavorãveis: poço-tí po $P_{2}$ do aquifero Açu $\left(0,0108\right.$ oRTNs) e poço-tipo $P_{6}$ do aquifero Barreiras $(0,0025$ ORTNs), fazem notar que a produção de ăgua do aquífero Jandaira è relativamente mais onerosa. 
TABELA 25 - Custo de produção do $\mathrm{m}^{3}$ de ãgua pelos poços-padrão

\begin{tabular}{|c|c|c|c|c|c|c|}
\hline \multirow{3}{*}{ Discriminação das despesas } & \multicolumn{4}{|c|}{ Custos de produção do $\mathrm{m}^{3}$ pelos } & poços padră & \\
\hline & \multicolumn{2}{|l|}{$\mathrm{P}_{1}$} & \multicolumn{2}{|c|}{$\mathrm{P}_{2}$} & \multicolumn{2}{|c|}{$\mathrm{P}_{3}$} \\
\hline & $\operatorname{cr} \$$ & ORTNS(0) & $\operatorname{Cr} \$$ & ORTNS & $\operatorname{cr} \$$ & ORTNS \\
\hline Valor anual de custo comum & 1626200,00 & 215,50 & $1626.200,00$ & 215,50 & $1626.200,00$ & 215,50 \\
\hline Despesas com energia & 267036,00 & 35,39 & 251343,00 & 33,31 & 518336,00 & 68,69 \\
\hline TOTAIS & $1893.236,00$ & 250,89 & $1877.543,00$ & 248,81 & $2144.536,00$ & 284,19 \\
\hline Custo do $\mathrm{m}^{3}$ de água & \multicolumn{2}{|c|}{$87,650,0116154$} & \multicolumn{2}{|c|}{$43,46 \quad 0,0057593$} & 16,55 & 0,0021932 \\
\hline
\end{tabular}

(a) Valor da ORTN de janeiro/84: $\operatorname{Cr} \$ 7545,98$ 


\section{CONCLUSÕES}

A presente monografia, tendo reunido os conhecimentos ad quiridos através dos diversos estudos hidrogeolögicos envolvendo - dominio do aquífero Jandaira da Bacia Potiguar, permitiu um melhor entendimento do funcionamento desse aquifero. A sua com plexidade limitou porém o desenvolvimento adequado das investi gações, impedindo que fosse atingido um grau de entendimento de sejävel de todos os fenômenos hidrogeológicos nele ocorrentes.

- Na evolução dos conhecimentos sobre o aquífero Jandaíra me recem destaque a participação dos estudos exploratōrios da. SUDENE, que a selecionou como Bacia Escola de Hidrogeologia, e o Governo do Estado do Rio Grande do Norte, com estudos regionais volta dos à avaliação dos recursos hídricos subterrâneos do Estado.

- Mapeamentos, sonḍagens mecānicas e geofísicas da PETROBRÁs e da SUDENE em muito vêm contribuindo para o conhecimento espa cial e estrutural dos vários estratos da Bacia potiguar em que pesem algumas dificuldades de interpretação de sondagens elétri cas verticais.

- As rochas carbonäticas da Formação Jandaira abrangem uma superficie de cerca de $17756 \mathrm{~km}^{2}$ estendendo-se desde a porção oriental do Estado do Ceará até o extremo leste do Estado do Rio Grande do Norte. A superfície de domínio do aquifero Jandaí ra foi considerada porẻm com $16278 \mathrm{~km}^{2}$, somente atë uma linha unindo as cidades de Touros e Pureza, no extremo nordeste da ba cia, devido ao desconhecimento geológico-estrutural a leste des sa linha e à supremacia do aquífero Barreiras sobre os aquífe ros Jandaíra e Açu nessa região. Seu domínio está inserido em região de clima semi-ārido do nordeste brasileiro, no denomina do Poligono das secas.

- Por toda a sua extensão, o aquífero Jandaira e limitado na base por uma camada pouco permeável, de espessura mäxima de $800 \mathrm{~m}$ na parte central da bacia, e que da base para o topo é consti tuida por arenitos, siltitos argilosos, argilitos, folhelhos., margas, calcarenitos e calcários compactos, pertencentes à por ção superior da Formação Açu e à porção inferior da. Formação Jandaira. Essa camada funciona hidraulicamente como aquitardo, atravēs do qual se faz a conexão hidrāulica entre os aquíferos Jandaira e Açu a ele sotoposto, responsāvel pelo aporte de 
$1,4 \times 10^{6} \mathrm{~m}^{3} / \mathrm{a}$ de äguas no aquifero Jandaira provenientes do aqui fero Açu, por drenança vertical ascendente, e pela transferência de $4,49 \times 10^{6} \mathrm{~m}^{3} / \mathrm{a}$ de äguas para o aquífero Açu, por drenança ver tical descendente.

- Junto à costa, com um paleo-relevo bastante irregular, a Formação Jandaira é recoberta por uma faixa de sedimentos ter ciários e quaternārios com largura e espessura bastante variá veis, onde se instala, de maneira descontinua, o sistema aquí fero Dunas-Barreiras. Esse sistema é limitado na base por uma camada pouco permeävel, constituída por leitos argilosos e às vezes margosos com espessura média de $15 \mathrm{~m}$ que o separa do aquí fero Jandaira, conferindo-lhe carāter de semi-confinamento em algumas áreas. Esse sistema constitui uma das fontes de recarga do aquifero Jandaira que, por drenança vertical descendente atra vês da camada semi-confinante, lhe transfere um volume de ãgua da ordem de $2,5 \times 10^{6} \mathrm{~m} / \mathrm{a}$, e que influencia tambēm a composição quimica das suas äguas.

- A recarga do aquifero Jandaira se processa essencialmente pela infiltração de ăguas pluviais em sua superficie livre, cujas äreas preferenciais se instalam em regiões topograficamen te elevadas, evidenciando-se notāvel coincidência entre a loca lização dessas äreas com as regiões de maior frequência e densí dade de fraturamento. Na porção ocidental da bacia as äreas pre ferenciais de recarga se localizam na região da Serra de Mosso ró, onde têm carga hidräulica māxima de $125 \mathrm{~m}$, e na região de Maxixe, localizada na porção central da Chapada do Apodi, com carga hiarâulica mäxima de $132 \mathrm{~m}$. No domínio central da bacia se situam na região de sombras Grandes na zona do interflúvio dos rios Apodi-Mossorö e Upanema-do Carmo, com carga hidräulica mäxima de $100 \mathrm{~m}$, e também na região de Volta-Trapiá entre os rios do Carmo e Piranhas-Açu, onde atinge $138 \mathrm{~m}$. Na porção oriental da bacia, as äreas preferenciais de recarga se localizam nas bordas do domínio, nas vizinhanças do contacto entre as forma ções Jandaira e Açu na região denominada genericamente de serra Verde de uma forma continua, desde sudoeste de Jandaira atë nor te de João Câmara, onde atinge a mais elevada carga hidráulica do aquífero, da ordem de $200 \mathrm{~m}$. No interior do domínio, pode ser citada a região da Serra dos Macacos, localizada a sul de Queimadas, com 179 m. Essas äreas deverão ser portanto preferen 
cialmente consideradas sob os aspectos de preservação ambiental e ocupação do solo em eventuais planos de aproveitamento dos recursos hídricos do aquifero Jandaira.

Secundariamente a recarga se processa com aportes por dre nança a partir dos aquíferos Açu e sistema Dunas-Barreiras.

Caracteristicamente livre, o aquifero Jandaira apresenta as profundidades dos níveis d'água em estreita relação com $\circ$ re levo, encontrando-se as maiores profundidades de nivel nos in terflúvios, nas āreas preferenciais de recarga do aquifero, co mo por exemplo na região da Serra de Mossoró onde atinge a pró fundidade de $71 \mathrm{~m}$; na região de Maxixe, com $40 \mathrm{~m}$; nas serras do Carmo e do Mel, com $170 \mathrm{~m}$ e na porção oriental da Bacia, atinge $134 \mathrm{~m}$ na região da Serra da Macambira e $138 \mathrm{~m}$ na Serra dos Maca cos. Os menores valores geralmente são encontrados nos seus exu tórios junto aos vales dos principais rios e orla atlântica. Dí ferenças bruscas de profundidades de nível a curtas distâncias, como as que ocorrem nas serras do Carmo e do Mel, sugerem a existência de aquiferos suspensos nessas ăreas. Inexistem medi ções periódicas de nível que possam fornecer a sua evolução no decorrer do tempo e a amplitude da variação anual. Medições efe tuadas no intervalo de 9 meses (abril/79 e janeiro/80) revela ram desde ausência de variacão atē redução de nivel, em média da ordem de $3 \mathrm{~m}$ nesse período. Como as chuvas na região se ini ciam em dezembro, é provável que na ocasião das últimas medi ções os niveis jã estivessem influenciados pela recarga do aquí fero.

- Consideradas a grande variação na constituição litológica tanto vertical como horizontal dos calcărios Jandaira, as des continuidades lineares, as evidências de carstificação e ainda a amplitude dos valores de vazão específica e de transmissivida de pode-se concluir que o meio aquifero se apresenta heterogê neo, descontínuo e hidraulicamente anisotröpico, promovendo cir culação tipicamente cărstica no seu interior, ou seja, se pro cessa essencialmente através de fendas e canais, além do que muitas vezes parte do fluxo se faz através de camadas arenosas presentes no interior da sequência carbonática, principalmente nas proximidades dos vales dos rios Mossoró, Açu e Mulungu.

- As direções de fluxo, quando consideradas em ăreas restrí tas geralmente coincidem com as direções de maior freqtência e 
com as direções de malores comprimentos relativos (em rela ção ao dominiol das descontinuidades.

De uma maneira geral, as equipotenciais condicionam o flu xo subterrâneo de sul para norte, em direção ao oceano, com grâ diente médio de $10^{-3}$, interiorizando as águas no domínio do aquí fero a partir das äreas de recarga; secundariamente o dirige pa ra os vales dos rios Apodi-Mossoró, Upanema-do Carmo, PiranhasAçu e Cabugi-Mulungu-Amargoso ou mesmo para o exterior do domí nio; para oeste, em direção ao vale do rio Jaguaribe, para leste, em direção à Iagoa do Boqueirão e vale do rio Maxaranguape.

A interceptação desse escoamento pela topografia permite o surgimento das fontes mais expressivas, tais como a fonte de Pu reza, no extremo leste e a de Olho d'Agua da Bica no. extremo oeste do domínio do aquífero.

Escoamento subterrâneo pouco expressivo se processa para sul, garantido por poucos e curtos feixes de linhas de fluxo em direção ao contacto entre as formações Jandaíra e Açu. Assim, na parte ocidental e central da bacia hã escoamentos em direção às cabeceiras do riacho da Barra, localizado a noroeste de Apo di, em direção ao riacho Baixa Grande, localizado a noroeste de Upanema e tambēm em direção às cabeceiras do rio Palheiro e La goa do Piatö, localizados a noroeste de Açu. Esses escoamentos são responsāveis pela manutenção de pequenas fontes e exudações da "cuesta" calcāria nessas regiões.

- A partir da interpretação de 74 ensaios de bombeamento fo ram obtidos valores de transmissividade (T) que variam de $1 \mathrm{x}$ $10^{-4}$ até $78,50 \mathrm{~m}^{2} / \mathrm{h}$; com média de $3,15 \mathrm{~m}^{2} / \mathrm{h}$, cuja amplitude re flete a heterogeneidade do meio aquífero. Valores de coeficien te de armazenamento não puderam ser calculados uma vez que não se dispunham de medidas de nível em poços de observação nas pró ximidades dos poços ensaiados.

A produtividade dos poços è bastante variävel pois as va zões específicas $(Q / \mathrm{s})$ variam de 0,01 atē $48,0\left(\mathrm{~m}^{3} / \mathrm{h}\right) / \mathrm{m}$, com mé dia de $4,69\left(\mathrm{~m}^{3} / \mathrm{h}\right) / \mathrm{m}$. Deve-se frizar porém, que 758 dos dados de vazão específica estão compreendidos entre 0,01 e $6,20\left(\mathrm{~m}^{3} / \mathrm{m}\right) / \mathrm{m}$, havenđo uma frequência ao redor de apenas $10 \%$ para vazões entre 0,5 e $12\left(\mathrm{~m}^{3} / \mathrm{h}\right) / \mathrm{m}$. As maiores vazões especificas estão compreen didas entre as profundidades de 20 a $140 \mathrm{~m}$, conforme revelou a 
curva representativa das mëdias acumuladas dos valores de vazão especifica para intervalos de $10 \mathrm{~m}$.

A anâlise do comportamento espacial das vazões específicas torna notōria a relação entre os seus altos valores e a presen ça de fraturamentos, permitindo supor que uma das formas de $x$ e duzir os insucessos de construção de poços pouco produtivos se ja a execução de estudos hidrogeológicos de detalhe nas áreas de interesse, levando-se em consideração principalmente os as pectos estruturais dos calcários.

A melhoria de produtividade dos poços pouco produtivos po deria ser obtida por processos artificiais de aumento da permea bilidade do reservatório nos arredores do poço pelo método de acidificação ou mesmo por detonações seguidas de acidificação.

Atravēs de anālise de regressão entre os valores de trans missividade e de vazão especifica dos poços ensaiados foi obti da a relação entre ambas, expressa pela equação:

$$
\log \mathrm{T}=-0,37+1,14 \log 2 / \mathrm{s}
$$

Assim foi posíivel a obtenção de um grande nümero de valo res de $T$ a partir dos dados de $\Omega / s$, que permitiu a compartimen tação bastante detalhada das frentes de descarga do aquífero pa ra a avaliação dos volumes escoados nos seus exutōrios naturais. - Tẻcnicas utilizando isótopos ambientais têm sido emprega das em investigações envolvendo as āguas subterrâneas do aquífe ro Jandaíra. Analisando-se dados de concentrações de $D$ e $\mathrm{O}^{18}$ pō de-se verificar que o coeficiente angular da reta representati va da relação entre $\delta D$ e $\delta 0^{18}$ para āguas dos aquíferos Jandaíra e Açu $\left(\delta D=0,55+5,6 \delta 0^{18}\right)$ quando comparado ao da equação de CRAIG (196I), "apud" SALATI et alii (1976), representativa das äguas meteōricas $\left(\delta \mathrm{D}=10+8,0 \delta 0^{18}\right)$ è relativamente baixo, aproximando-se do coeficiente angular da reta representativa das äguas de açude no Estado do Ceará $\left(\delta D=0,4+4,980^{18}\right)$, con forme SANTIAGO (1972). Tal fato permite concluir que as äguas armazenadas nesses aquiferos sofreram intenso processo de evapo ração antes de aportarem nos respectivos aquiferos. Essa evapo ração estaria contribuindo portanto para o processo de concen tração de sais nas porções superficiais dos terrenos.

A anālise do comportamento de algumas medidas de salinida de expressas pelo Residuo seco (RS a $110^{\circ} \mathrm{C}$ ) das äguas de poços 
e cacimbas, comparativamente à pluviosidade medida em estações próximas ãqueles, revelou uma estreita relação entre ambas: a salinidade das äguas aumentando paralelamente à pluviosidade. A menos de uma pequena defasagem no tempo haveria correspondên cia, entre os mäximos valores da pluviosidade e os valores de Residuo seco. Embora sejam bastante reduzidos o número de pon tos d'ägua analisados e os periodos pode-se, aceitando-se a exis têncla de tal fato, admitir que seja esse o mecanismo pelo qual se processa a salinização das āguas subterrâneas do aquífero Jandaira. Assim, as äguas pluviais dissolvendo sais existentes na camada não saturada, originados por processos pedogenēticos e concentrados por processos climăticos, seriam responsäveis pe la sua veiculação atẻ a porção saturada do aquifero nas épocas de maior pluviosidade e recarga do mesmo.

A caracterização hidroquímica do aquífero Jandaíra permi tiu verificar que as äguas de armazenamento são essencialmente bäsicas, com pH variando de 6,5 até 8,9 e apresentam salinidade bastante elevada, com TSD (total de sais dissolvidos) variando de 270,27 atē $11342,00 \mathrm{mg} / 1$, com mëdia de $1793,06 \mathrm{mg} / 1$. Em $75 \%$ das amostras os valores de TSD variam de $270,27 \mathrm{mg} / 1$ atẻ $2500,00 \mathrm{mg} / 1$ havendo estreita relação entre a salinidade das ãguas e teor de cloretos. Embora, segundo a classificação proposta por CUSTODIO (1976), $71 \%$ das amostras estejam colocadas na categoria de água doce, tem-se $23 \%$ das amostras na categoria de ägua salobra e 5 ơ na categoria de ägua salgada.

No que se refere ao comportamento espacial da salinidade, expressa em valores de TSD, notou-se que de una maneira geral hã aumento de concentração salina em direção aos vales dos prin cipais rios tais como o rio Mossoró e Açu e em direção ao mar, ou seja, em direção aos exutörios do aquifero, portanto com ten dência natural de aumento da concentração salina de montante pa ra jusante do fluxo subterrâneo. São notörios porēm núcleos com salinidade relativamente elevada, tanto junto ao litoral como no interior do domínio. Zonas com salinidade relativamente redu zida foram tambēm identificadas ora junto às ăreas preferen ciais de recarga, ora em äreas próximas aos sedimentos do Grupo Barreiras e ainda em āreas de maior pluviometria, no "extremo oriente do dominio. 
Os núcleos litorâneos com concentrações de TSD anormalmen te elevadas: que tambēm se destacaram nos mapas de Dureza e de cloretos, têm provavelmente suas origens na influência das āguas marinhas. Estas contaminariam as äguas do aquifero pelo:. seu avanço para o interior, tanto atravës dos vales dos principais rios por ocasião das marés altas, como através das ređes do sís tema cārstico que, como soe acontecer, são extraordinariamente desenvolvidas junto ao mar, pelo aumento da agressividade das águas provocado pela mistura que se processa nesses exutórios. os núcleos interiores com concentrações elevadas teriam sua orí gem na presença de solos salinos da cobertura, além do aumento natural de concentração de sais, jā no aquífero, devido à baixa velocidade de circulação das ãguas subterrâneas nessas äreas.

- Como a condutividade elëtrica (CE) reflete o teor salino das águas e sendo este de grande interesse para o estudo do aquí fero Jandaira, foram feitas diversas anālises de regressão en volvenđo esta variável, com o objetivo de avaliar as suas rela çöes de dependência com outros parämetros de interesse. Não fo ram encontrados no entanto bons níveis de interdependência en tre a condutividade elétrica, tanto com a vazão especifica ( $Q / s)$ como tambēm com a transmissividade (T). Embora seja bastante re duzido o coeficiente de correlação encontrado na anälise de re gressão entre esta e a profundidade do nível d'ägua e entre a espessura dos sedimentos sobrepostos do aquifero Jandaira, poder-se-ia dizer que a condutividade elētrica se reduz levemente para valores crescentes dessas duas variáveis.

$A$ anālise de regressão entre a condutividade elétrica $e$ o Residuo seco permitiu a obtenção da equação $\mathrm{CE}=1,04$ RS, ütil na determinação de Resíduo seco a partir de valores de conduti vidade elētrica. Da mesma forma foram obtidas as equações re presentativas da relação entre a condutividade elētrica(em $\mu$ mo/ $\mathrm{cm}$ a $25^{\circ} \mathrm{C}$ ) e a soma de Ions (em $\mathrm{mg} / \mathrm{l}$ ) para os diferentes grupos de ăguas, a saber:

$\mathrm{CE}=0,67$ (Soma de íons) - äguas com dominância de cloretos;

$\mathrm{CE}=0,74$ (Soma de Ions) - àguas com dominăncia de bicarbonatos e carbonatos;

$\mathrm{CE}=0,82$ (Soma de ions) - ãguas com dominância de sulfatos, e $C E=0,68$ (Soma de Ions) - para todo o conjunto. 
- A Dureza total das äguas do aquifero Jandaỉra è geralmente elevada, levando a quase totalidade das amostras (968) a serem classificadas na categoria de águas muito duras, segundo a clas sificação proposta por CUSTÓdIO \& LIAMAS (1976). Os valores vą riam de 85,00 até $6186,90 \mathrm{mg} / 1$, com mëdia de $898,13 \cdot \mathrm{mg} / 1$ : de $\mathrm{CaCO}_{3}$ equivalente e para $75 \%$ das amostras os valores de Dureza total estão compreendidos entre 85,00 e $1300,00 \mathrm{mg} / 1$ de $\mathrm{CaCO}_{3}$ equivalente, tratando-se essencialmente de dureza devida a nãocarbonatos.

- comportamento espacial da Dureza total, da mesma forma que $O$ TSD e os cloretos também se faz crescente no sentido do fluxo subterrâneo. Os nücleos de teores elevados correspondem às mesmas āreas encontradas nos mapas de TSD e de cloretos. E notória a correspondência entre os teores de Dureza total e a mineralogia dos calcários encontrando-se os altos valores de Du reza em āreas de dominância dos calcários aflorantes de alta pü reza, conforme distribuição configurada por MENOR et alii (1980), correspondentes às rochas carbonätico-magnesianas com $\mathrm{MgO}>28$; os valores menos elevados são encontrados em äreas onde $\mathrm{Ca}>53 \%$ e Mgo < 28, principalmente no extremo leste do domínio.

- Relativamente aos ânions maiores, segundo a classificação proposta por SCHOELLER, "apud" CUSTODIO \& LLAMAS (1976) as àguas do aquifero Jandaira são representadas por $52 \%$ de äguas cloreta das, $21 \%$ de äguas bicarbonatadas, $6 \%$ de äguas sulfatadas e 21 \% de āguas mistas. A distribuição dessas ăguas observada atravēs do mapa de diagramas de stiff, faz notar que as águas sulfata das da região localizada a noroeste da cidade de Gov. Dix-Sept Rosado estão associadas a evaporitos presentes naquela região. Nesse sentido é importante destacar tambēm a ocorrência de äguas sulfatadas a oeste da serra do Carmo, a sudeste de Alto do Rodrigues e na área que se estende desde sudoeste atē sudes te de Parazinho, que podem estar revelando a presença de evapo ritos tambëm nessas äreas.

A dominäncia dos cloretos se efetiva em 628 das amostras, com teores que vão de 27,87 até $7043,40 \mathrm{mg} / 1$. Para $75 \%$ das amostras os teores de cloretos são bastante elevados, vàriando entre o teor minimo e $950,00 \mathrm{mg} / \mathrm{l}$.

- Com uma espessura mëdia saturada de $150 \mathrm{~m}$ e porosidade efi caz de $5 \times 10^{-2}$ estima-se que as reservas permanentes do aquife 
ro Jandaira sejam da ordem de $122 \times 10^{9} \mathrm{~m}^{3}$; as reservas reguladoras, for am avaliadas como sendo da ordem de $56,6 \times 10^{6} \mathrm{~m}^{3} / \mathrm{a}$, garantidos por infiltração eficaz de $0,9 \%$. Consequentemente fica fixado o coficiente de realimentação anual como sendo da ordem de 0,058 .

No que concerne à qualidade das reservas de ãgua do aquífe ro Jandaira pode-se concluir que:

- quanto à adequação para consumo humano suas ăguas podem ser consideradas insatisfatörias quando se comparam os teores de alguns de seus constituintes ou valores de parâmetros físicoquímicos com os padrões estabelecidos em legislação específi ca. Assim, a salinidade das āguas expressa em TSD, ultrapassa - valor mäximo permissivel em 69 o das amostras; a Dureza to tal è superior ao máximo tolerado em $95 \%$ das amostras; o teor de Magnésio é superior ao permitido em 778 das amostras;. o teor de flūor em $96 \%$ das amostras se situa fora do intervalo recomendado para a região $\left(6,0-8,0 \mathrm{mg} / 1\right.$ de $\left.\mathrm{F}^{-1}\right)$, e o teor de bicarbonato é superior ao mäximo permissivel em $51 \%$ das amostras;

Teores elevados de nitrato revelam processo de poluição das águas por substâncias orgânicas. Em $20 \%$ das amostras : 0 teor de nitrato é superior ao mäximo permissivel de $45 \mathrm{mg} / 1$ de $\mathrm{ni}$ trato (em $\mathrm{mg} / \mathrm{l}$ de $\mathrm{NO}_{3}^{-l}$ ). Essas amostras correspondem a poços da zona rural, localizados nos campos de pastagem ou nas pro ximidades de currais. A análise desses poços leva a supor os seguintes mecanismos de poluição: ausência: de quarnecimento de tampa na boca dos poços, boca do poço situada abaixo da super fície do terreno e ausência de cimentação de proteção na parte superior do poço. Tais situações permitiriam o acesso de ăguas poluídas diretamente, pelo interior do poço, ou indire tamente, pelo furo não cimentado, às äguas do aquífero. Cuida dos especiais deveräo portanto ser tomados quando do revesti mento do furo, cimentações e da instalação dos equipamentos de bombeamento alēm do estabelecimento efetivo de perímetro de proteção da captação para garantir a preservação da quali dade das āguas extraídas.

- no que diz respeito à utilização para fins de irrigação pode -se constatar que, de acordo com a classificação do united States Salinity Laboratory (USSL), 518 das amostras de ăguas 
do aquifero Jandaíra se enquadram na classe $C_{3} S_{1}$, seguindo-se a classe $\mathrm{C}_{4} \mathrm{~S}_{2}$ com $25 \%$. Isto significa que a máioria das äguas apresenta alta salinidade e relativamente baixo risco em sō dio, podendo ser aplicadas somente em culturas com alta tole rância aos sais e em solos de alta permeabilidade e boa dre nagem, devendo-se utilizar ägua em excesso para promover a 1 i xiviação dos mesmos. A aplicação, portanto, das āguas do aquí fero Jandaíra para irrigação deverá ser precedida de estudos pedolögicos de detalhe da área a ser irrigada, e

- para consumo industrial, as ãguas do aquífero Jandaíra não são recomendadas sem que se as submeta a tratamento prēvio, devido principalmente ao seu carāter incrustante evidenciado pelos baixos valores do índice de estabilidade do carbonato de cálcio (IE) aqui, calculado segundo RYZNAR (1944), que va riam de 4,68 até 9,57 , com um valor médio de 7,69 , revelando que a maioria das äguas tem carāter francamente incrustante.

Para adequä-las ao uso industrial seria necessário tratamento prévio específico segundo o tipo de indústria ou processo in dustrial utilizado.

Com base nos mapas hidroquímicos elaborados neste estudo, é possivel o conhecimento apriorístico da composição química aproximada e das características físico-quimicas das ăguas de novos poços a serem construídos, tornando-se assim possĩvel a previsão da qualidade das ãguas a serem explotadas. Tal conheci mento prëvio será ütil no planejamento do aproveitamento dos re cursos hídricos subterrâneos do aquífero Jandaira e mesmo no planejamento do uso e ocupação do solo, adequando, quando ne cessārio, as atividades e ocupações humanas à qualidade das ăguas disponíveis.

- No que se refere à explotação das äguas do aquífero Jandaí ra, no seu domínio pertencente ao Estado do Rio Grande do Nor te, correspondente a $90 \%$ da sua superfície, foram cadastrados 853 poços tubulares que captam suas äguas, construídos atē 1979, equivalentes a 658 dos poços construidos naquele estado. Entre os poços cadastrados, 728 (615 poços) são de iniciativa particu lar e $25 \%$ (217 poços) são poços püblicos, sendo que $62 \%$ poços) se encontram em operação e $19 \%$ (158 poços) foram abando 
nados. As principais causas de abandono foram a reduzida vazão de produção, ocasionais desmoronamentos das paredes do furo quando não revestidos e, menos frequentemente, a alta salini dade das äguas produzidas.

Os poços tubulares são geralmente construídos pelo sistema percussivo a cabo tendorse registrado profundidade máxima de $300 \mathrm{~m}$. O maior valor encontrado para as vazões foi de $40 \mathrm{~m}^{3} / \mathrm{h}$. , porēm em $95 \%$ dos poços a vazão não ultrapassa $10 \mathrm{~m}^{3} / \mathrm{h}$. Os níveis estāticos estão à profundidade máxima de $45 \mathrm{~m}$ para $75 \%$ dos poços.

- Como equipamento de bombeamento são utilizados cataventos em $33 \%$ dos poços, seguindo-se o sistema "air lift" em 228 e bom bas injetoras em 17\% dos poços; bombas submersiveis são instala das em apenas $3 \%$ dos poços construidos.

Nessas condições o volume de äguas anualmente explotadas ē da ordem de $3,6 \times 10^{6} \mathrm{~m}^{3}$ (em 1979).

- A pertinência da ärea ao polígono das secas e as dificuldą des da obtenção de ãgua de melhor qualidade premem que se as utilize para os mais diversos fins, tendo sido desprezadas as limitações de uso baseadas en parâmetros legais.

Hä bastante dificuldades em definir a destinação específi $c a$, em termos de volumes explotados, uma vez que em uma grande quantidade de poços a ăgua é utilizada para fins mültiplos sem contudo haver controle de elementos que possam permitir o cálcu lo dos volumes de cada destinação. As informações levantadas, no entanto, permitiram identificar alguns usos, tendo-se $37 \%$ do vo lume explotado com destinação para uso domēstico e animal, 23 \& para uso agropecuário e $13 \%$ para uso exclusivamente domēstico, entre outros. Deve-se ressaltar no entanto, que é expressivo o volume destinado ao uso na pecuária uma vez que as āguas explo tadas atravês dos poços para abastecimento püblico e que repre sentam 238 dos volumes, têm fins mültiplos, incluindo-se portan to também aqui o uso na pecuária. 


\section{REFERENCIAS BIBLIOGRAFICAS}

ALBUQUERQUE, J.P.T. 1970. Inventärio hidrogeolögico bäsico do Nordeste: folha 15, Jaguaribe - SE. Recife, SUDENE. (SUDENE. Hidrogeologia, 32).

ALMEIDA, F.F.M. de. 1969. Diferenciação tectōnica da plataforma brasileira. In: CONGRESSO BRASILEIRO DE GEOLOGIA, 23, Salva dor, 1969. Anais... Salvador, SBG. p.29-46.

ARAOJO, J.M. de C. \& RODIS, H.G. 1967. Recursos d'ägua subter rânea da ärea do Vale Açu. Recife, SUDENE. 41 p.il. (SUDENE, Hidrogeologia, 12).

ARAOJO, M.B.; GOMES, J.B.; SOUZA, S.M. 1978. Bacia Potiguar; as pectos gerais e perspectivas petroliferas. (Offshore Brasil, OB-78-02: 1-11. RJ) .

ASMUS, H.E. 1975. Controle estrutural da deposição mesozóica nas Bacias da margem continental brasileira. Rev. Bras. Geoc. são Paulo, 5 (3): 160-175.

ASNUS, H.E. 1981. Geologia das bacias marginais mesozöicas-ceno zöicas do Brasil. Buenos Aires, Comité Sudamericano del Ju rásico y Cretäcico, Cuencas Sedimentarias del Jurásico y Cre täcico de America del Sur. v.1, p.127-155.

ASMUS, H.E. 1981. Relacionamento genëtico e feições geológicas da margem continental suđeste brasileira e da ārea conti nental emersa adjacente. In: SIMPOSIO REGIONAL DE GEOLOGIA, 3, Curitiba, 1981. Atas... São Paulo, SBG, v.1, p.252-261.

ASMUS, H.E. \& PORTO, R. 1972. Classificação das Bacias sedimen tares brasileiras segundo a tectōnica de placas. In: CONGRES SO BRASILEIRO DE GEOLOGIA, 26, Belëm, 1972. Anais... Belēm, SBG. v. 2, p. 67-90.i1.

BARBOSA, A.J. \& BRAGA, A. de P.G. 1974. Projeto leste da Parai ba e Rio Grande do Norte; relatörio integrado. Recife, DNPM/ CPRM. v. 3 . 
BAZILEVICH, N.I. 1965. The geochemistry of soda soils; Moscou, V.A. Kovda. Traduzido por Israel Program for Scientific Trans lations, 1970, Jerusalèm, R. Amoils. 392p.il.

BELTRÃO, A.E. de A. 1974. Aspectos hidrogeológicos do Territó rlo Federal de Fernando de Noronha. Recife, SUDENE. 52p.il. (SUDENE, Hidrogeologia, 49).

BEURLEN, K. 1961. O Turontano marinho no nordeste do Brasil.Bol. Soc. Bras. Geol., São Paulo, 10 (2):39-52.

BEURLEN, K. 1964. Novas observações sobre o Cretäceo do Rio Grande do Norte. Bol. Paranaense de Geografia, (10-15):173178.

BEURLEN, K. 1967. Geologia da região de Mossorō. Rio de Janeiró, Pongetti. 173p. (Coleção Mossoroense: Série C, v.18).

BEZERRA, M.A. 1978. Avaliação da capacidade de produção dos po cos do sistema de abastecimento d'água de Natal, RN. Recife. 134p.11. (Dissertação apres. UFPE. Grau de Mestre. Area de concentração em Hidrogeologia).

BLANKENAGEL, R.K. 1962. Geological Sumary and Ground Water Po tential of the Potiguar Basin in Rio Grande do Norte. Rio de Janeiro, PETROBRAS/DEPEX. 22p. (inëdito).

BRASIL. Ministērio de Minas e Energia. Secretaria Geral. 1981. Projeto RADAMBRASIL; Folhas SB 24/25. Jaguaribe/Natal; geo logia, geomorfologia, pedologia, vegetação e uso potencial da terra. Rio de Janeiro. 744p.il. (Levantamento de Recursos Naturais, 23).

CAMPos, M. de et alii. 1979. Projeto Rio Jaguaribe, Estados do Cearā, Rio Grande do Norte e Paraỉba; relatório final de geo logia. Brasilia, DNPM. 149p. (DNPM. Séxie Geologia, 4, Seção Geologia Bāsica, 1).

CAMPOS, \& SILVA, A. 1968. O Grupo Barreiras e unidades correla tas no Rio Grande do Noxte. In: SIMPOSIO DE GEOLOGIA DO NOR DESTE, 4, Recife, 1968. Resumo das comunicações... Recife, SBG. p. 21-22. 
CAMPOS, \& SILVA, A. 1965. O Grupo Barrelras na região de Natal. Natal, Univ. Fed. Rio Grande do Norte, Inst. Antropol. 4p. (Relatório comum, geol. 1).

CAMPOS, \& SILVA, A.; MABESOONE, J.M. \& BEURLEN, K. 1971. Estra tigrafia do Grupo Barreiras nos Estados do Rio Grande do Nor te, Paraiba e Pernambuco. Rev. Bras. Geol., Recife, I (2): $1-13$.

CLIMATOLOGIA, geologia e recursos hidricos s.d. s.1., Consórcio TAHAL-SONDOTECNICA. CaP. 3 .

COMMITTEE ON WATER QUALITY CRITERIA. 1972. Water guality crite ria, 1972. Washington, Environmental Protection Agency.

COMPANHIA DE ĂGUAS E ESGOTOS DO RIO GRANDE DO NORTE - CAERN. 1970. Estudo hidrogeológico de Natal, RN. Recife, Consulto ria Técnica de Geologia e Engenharia. 224p.il.

COMPANHIA DE PESQUISAS DE RECURSOS MINERAIS - CPRM. 1978. Mapa geológico preliminar do Rio Grande do Norte; escala 1:500 000. Recife.

COMPANHIA NORDESTINA DE SONDAGENS E PERFURAÇÕES - CONESP. 1965/ 66. Perfis litológicos de 20 pocos rasos, perfurados para āgua na Bacia Potiguar. São Paulo. (inédito).

CRANDALI, R. 1910. Geografia, Geologia, suprimento d'ägua, trans portes e acudagem nos Estados orientais do Norte do Brasil: Ceară, Rio Grande do Norte, Paraîba, Rio de Janeiro, Minis tërio de Viação e Obras püblicas, Inspetoria de Obras Contra Secas. 132p.il. (Publicação IFocs no 4). (Série I.D.E. Hidro geologia, Geologia, Assuntos Gerais).

CRUZ, W.B. da. 1967. Alguns aspectos de circulação e saliniza ção de ãguas subterrâneas em rochas cristalinas no nordeste do Brasil. Recife, SUDENE. 20p.il. (SUDENE, Hidrogeologia, 8). CRUZ, N.B. da \& FRANÇA, H.P.M. 1970. Inventärio hidrogeológico bá sico do Nordeste: folha no 14, Jaguaribe-So. Recife, SUDENE. (SUDENE, Hidrogeologia, 31). 
CRUZ, W.B. da \& MELLO, F. de A.F. de. 1974, Estudo geoquímico preliminar das águas subterrâneas do nordeste do Brasil. Re cife, SUDENE. 128p.il. (SUDENE, Hidrogeologia, 19).

CUSTODIO, E. \& ILAMAS, M.R. 1976. Hidrologia Subterrânea. Barce lona, Omega.

CYPRIANO, J.L. \& NUNES, A.B. 1968. Geologia da Bacia Potiguar. Maceió, PETROBRAS, DEXPRO/DIVEX/RPNE. 74p. (Relatório inter no, 3088).

DANTAS, J.R.A. 1974. Carta geolögica do Brasil ao milionésimo: folha Natal, SB-25, folha Recife, SC-25. Brasilia, DNPM. 21p.

DEPARTAMENTO NACIONAL DE OBRAS CONTRA AS SECAS - DNOCS. 1976. Relatörio dos estudos hidrogeolögicos; Baixo Açu. Recife, SERETE.

DEPARTAMENTO NACIONAL DE OBRAS CONTRA AS SECAS - DNOCS. 1978. Plano diretor para o aproveitamento dos recursos de solo e ăgua no Vale do Apodi, Rio Grande do Norte. São Paulo, Hidro service. v. 2 e 3 .

DEPARTAMENTO NACIONAL DE OBRAS E SANEAMENTO - DNOS. 1969. Apro veitamento hidro-agrícola da Bacia do Rio Ceará-Mirim e da Lagoa de Extremoz. Rio de Janeiro, TAHAL/TEL-AVIV/SONDOTECNI CA. 3v.

DEPARTAMENTO NACIONAL DE PESQUISA AGROPECUARIA - DNPEA. Convê nio MA/DNPEA/SUDENE/DRN. 1971. Levantamento exploratörio - re conhecimento de solos do Estado do Rio Grande do Norte. Reci. fe. 53lp.il. (Série Pedologia no 9).

FEITOSA, E.C. 1978. Estudo geofísico por eletrorresistividade da porção ocidental da Bacia Potiguar, RN. São Paulo, IPT. (Rela törio interno).

GAMA, C.D. da. 1982. Computação gráfica interativa de dados geo lógicos vetoriais. In: SIMPOSIO BRASILEIRO DE SENSORIAMENTO REMOTO, Brasilia, 1982. Anais... Brasilia, CNPq/INPE. v.1, p.17-24.i1. 
HARGREAVES, G.H. 1965. Evapotranspiração e sua relação com a re carga de àgua subterrânea; traduzido por Luiz Tasso de Brito Dantas. Igua Subterrânea, 1 (2):32-41, mar/maio.

INSTITUTO DE PESQUISAS ENERGETICAS E NUCLEARES - IPEN. 1981. Avaliação dos recursos hĩaricos com aplicação de isōtopos no Rio Grande do Norte. São Paulo. (3 relatórios técnicos par ciais e um relatório têcnico final elaborado pelo IPEN/CARRED).

INSTITUTO DE PESQUISAS TECNOLOGICAS DO ESTADO DE SÃO PAULO-IPT.

1981. Reconhecimento hidrogeolögico e estudo sobre a quali dade atual das āguas subterrâneas da Grande Natal. São Paulo. 2 v. (IPT. Relatôrio, 14 813).

INSTITUTO DE PESQUISAS TECNOLOGICAS DO ESTADO DE SÃO PAULO-IPT. 1981. Ensaios geofísicos (sondagens elétricas verticais) em apoio ao estudo hidrogeológico regional detalhado do Estado do Rio Grande do Norte. São Paulo. (Relatório no 16 018).

- 1982. Estudo hidrogeológico regional detalhado do Estado do Rio Grande do Norte. São Paulo. 9 v. (IPT, Relatório no 15 795).

KEGEL, W. 1957. Contribuição ao estudo da bacia costeira do Rio Grande do Norte. Rio de Janeiro, DNPM. 52p. (DNPM. Boletim, 170).

LEAL, J.M. et alii. 1974. Caracterização de āguas do Nordeste Brasileiro com isótopos ambientais. Recife, SUDENE, Div. Do cumentação. 32p. (SUDENE, Hidrogeologia, 47).

LOGAN, J. 1965. Interpretação de anālises quỉmicas de água; trä duzido por Araknea Martins de Lemos. Recife, s.c.p. 74p.il.

MABESOONE, J.M. 1967. Sedimentologia da faixa costeira RecifeJoão Pessoa. Bol. Soc. Bras. Geol., 16 (1) :57-72.

MABESOONE, J.M.; CAMPOS e SILVA, A.; BEURLEN, K. 1972. Estratigrafia e origem do Grupo Barreiras em Pernambuco, Paraiba e Rio Grande do Norte. Rev. Bras. Geoc., 2:173. 
MAIOR, J.S. 1969. Ground water in northeastern Brazil. Recife, SUDENE. 82p.il. (SUDENE, Hidrogeologia, 21).

MANOEL FILHO, J. 1970. Inventärio hidrogeológico básico do nor deste; folha no 10: Jaguaribe-NE. Recife, SUDENE. (SUDENE, Hidrogeologia, 30).

MANOEL FILHO, J. 1972. Elementos de hidrogeologia prática. 2.ed. Recife, SUDENE. 353p.il. (SUDENE, Hidrogeologia, 13).

MANOEL FILHO, J. 1973. Reconhecimento hidrogeolögico da planí cie aluvial do Apodi, $\mathrm{RN}$; definição preliminar de viabilida de para irrigação. Recife, SUDENE. 84p.il. (SUDENE, Hidro geologia, 42).

MANOEL FILHO, J. et alii. 1969. Bacia Potiguar; estudo por ana logia elétrica das condições de exploração dàs āguas subter râneas do arenito Açu na região de Mossoró, RN. Recife, SU DENE. 78p.il. (SUDENE, Hidrogeologia, 23).

MELLO, Jr, J.L. 1965. Fosforita, calcārio, monazita e āgua sub terrânea nos Estados de Pernambuco, Paraỉba, Piauí, Maranhão e Rio Grande do Norte. s. L., DNPM.

MENOR et alii. 1980. Qualificação de rochas carbonáticas aflo rantes na Bacia do Apodi. In: CONGRESSO BRASILEIRO DE GEOLO GIA, 31, Balneārio Camboriú, SC. Anais.... Balneārio de Cam boriú, SC. SBG, v.3. p.1649-1663.

MERCADO, A. et alii. 1976. Utilização conjunta de dados hidro geológicos, hidroquímicos e isotópicos para avaliação do bạ lanço de āguas subterrâneas da Bacia Potiguar. Boletim de Recursos Naturais, Recife. SUDENE/DRN, $1 \underline{4}$ (1/2):33-61.

MINISTERIO DA AGRICULTURA. 1969. Atlas climatolögico do Brasil; redução de mapas selecionados. Rio de Janeiro, ECEPLAN, Es critório de Meteorologia, IBGE. 100p.il.

MINISTERIO DE MINAS E ENERGIA. Secretaria Geral. MME/SG. 1981. Projeto RADAMBRASIL; folhas SB-24/25, Jaguaribe/Natal; geolo gia, geomorfologia, pedologia, vegetação e uso potencial da 
terra. Rio de Janeiro. 744p.il. + Anexos. (Levantamento de Recursos Naturais, 23).

MIURA, K. \& BARBOSÄ, J.C. 1972. Geologia da plataforma continental do Maranhão, Piauí, Ceará e Rio Grande do Norte. In: CON GRESSO BRASILEIRO DE GEOLOGIA, 26, Belēm. Anais... Belém, SBG. v.2, p.57-66.

OJEDA, H.A.O. 1981. Estrutura, estratigrafia e evolução das bą cias marginais brasileiras. Rev. Bras. Geoc., 11, (4), dez. (no prelo).

OLIVEIRA, A.I. \& LEONARDOS, O.H. 1943. Geologia do Brasil. 2. ed. Rio de Janeiro. p.142-148.

PAIVA, G. de. 1937. Agua subterrânea: Estado do Rio Grande do Norte. Rio de Janeiro, DNPM/DFPM. p.142-148. (DNPM/DFPM, BOletim, 18).

PROJETO Rio Jaguaribe, relatōrio final. 1976. Recife,DNPM/CPRM. $15 \mathrm{v}$.

REBOUÇAS, A. da C. 1966. Faixa sedimentar costeira; Pernambuco, Paraíba, Rio Grande do Norte: aspectos hidrogeológicos. (Trab. apres. no Simpósio de Geologia do Nordeste, 2, Recife, 1966).

REBOUÇAS, A. da C. 1967. Estudo sedimentológico e paleontológi co de perfil das minas de gipsita. Mossoró. 22p. (Coleção Mossoroense. Série B, no 61).

REBOUÇAS, A. da C. 1968. Características hidrodinâmicas de al guns aquiferos do nordeste. In: SIMPOSIO DE GEOLOGIA DO NOR DESTE, 4, Recife, 1968. Resumo das comunicações... Recife, SBG/Nūcleo de Pernambuco. p.50-53il.

REBOUÇAS, A. da C. 1972. Hidrologia das secas. Nordeste do Bra sil. Recife, SUDENE. 126p.il. (SUDENE, Hidrogeologia, 47).

REBOUÇAS, A. da C. \& GASPARY, J. 1971. As āguas subterrâneas do Nordeste do Brasil: estimativas preliminares. 2.ed. Recife. SUDENE . (SUDENE, Hidrogeologia, 6). 
REBOUÇAS, A. da C.; MANOEL FILHO, J.; BENOIT, H. 1967. Bacia PO tiguar; estudo hidrogeolōgico. Recife, SUDENE. 2v.il. (SUDE NE, Hidrogeologia, 15).

RIJO, L. et alii. 1977. Interpretation of apparent resistivity data from Apodi Valley, Rio Grande do Norte, Brazil.Geophys. $\underline{42}$ (4):821-822.i1.

RYZNAR, J.W. 1944. A new index for determining amount of cal cium carbonate scale formed by a water. Journal American Wa ter Works Association, 36:472-486, Apr.

SALAMUNI, R. 1977. Geologia e geomorfologia entre Natal e Ponta Negra, RN; relatōrio técnico. Curitiba. (inédito).

SALATI, E.; LEAL, J.M.; CAMPOS, M.C. 1974. Environmental isoto pes used in a hydrogeological study of northearstern Brazil. In: ISOTOPE techniques in Groundwater hydrology. Vienna, In ternational Atomic Energy Agency. v.1, p.259-283.

SALATI, E. et alii. 1976. Estudo preliminar das concentrações de ol8 e D em águas do Nordeste brasileiro. Boletim de Recursos Naturais, SUDENE/DRN, $14(1 / 2): 63-92$.

SALIM, J.; LIMA, M. do S.; MABESOONE, J.M. 1973. FeiçÕes morfo lógicas do Rio Grande do Norte. In: CONGRESSO BRASILEIRO DE GEOLOGIA, 27, Aracaju, 1973. Anais... Aracaju, SBG. v.1, p. 421-426.

SAMPAIO, A.V. \& SCHALLER, H. 1968. Introdução à estratigrafia cretācea da Bacia Potiguar. Bol. Téc. Petr., Rio de Janeiro, 11, (1):19-44, jan/mar.

SANTOS, J.; COSTA, T.B. da; HAMZA, V.M. 1983. Projeto: determi nação do movimento de ägua subterrânea na Bacia Potiguar a partir de perfilagem de temperatura; relatörio final. Natal, Convênio SUDENE/UFRN. $101 \mathrm{p}$.

SANTOS, J.P. dos; AZEVEDO, S.G. de \& MISTRETTA, G. 1984. Novos aspectos da salinização das āguas subterrâneas do cristalino do Rio Grande do Norte. São Paulo, IPT. 40p. (Publicação IPT n8 1555 - Sêrie Comuniaação técnica, 314). 
SANTOS, M.A.V. dos. 1977. Estudo hidrogeolögico da planície alu vial do Apodi, RN; economicidade de poços para irrigação. Re cife, MINTER-SUDENE-DRN/MEC-UFPE-CT. Anexo 1, 2. (Convênio DRN-18/73).

SIAL, A.N. 1976. The post-paleozoic vulcanism of northeast Bra zil and its tectonic significance. In: INTERNATIONAL SYMPO SIUM on CONTINENTAL MARGINS of ATLANTIC TYPE, São Paulo,1975. Anais da Academia Brasileira de Ciências, 48 (suplemento):229311.

SOPPER, R.H. 1913. Geologia e suprimento d'água subterrânea do Rio Grande do Norte e Parahyba. s.L., IFOCS. (IFOCS. Boletim nọ 26. Série ID).

SOUTO MAIOR, J. 1969. Ground water in northeastern Brazil. Reci fe, SUDENE. 82p.il. (SUDENE. Hidrogeologia, 21).

SUPERINTENDENCIA DO DESENVOLVIMENTO DO NORDESTE - SUDENE. GrupO de Estudos do Vale do Jaguaribe. Convênio SUDENE/ASMIC. 1967. Estudo geral de base do Vale do Jaguaribe, Recife. 245p.il. (SUDENE. Hidrogeologia, 7). Association pour L'Organisation des Missions de Cooperation Technique - ASMIC.

SUPERINTENDENCIA DO DESENVOLVIMENTO DO NORDESTE. 1980. Plano de aproveitamento integrado dos recursos hỉdricos do nordeste do Brasil; fase 1. Recife.

- s.d. Estudos de reconhecimento e estudos hidrogeológicos para aproveitamento integrado; região centro-leste da Bacia Potiguar e bacias costeiras da Paraíba e Pernambuco - Área A. S.L., DRN/CONESP/OESA. V.5.

THRAILKILL, J. 1968. Chemical and Hydrologic factors in the ex cavation of limestone caves. Geological Society of America Buletin, 79:19-46, jan.

TODD, D.K. 1959. Hidrologia de āguas subterrâneas, trad. Araken Silveira e Evelyna Bloem Souto Silveira. São Paulo, Edgard Blthcher. 
VEGESACK, M. de. 1954. As āguas subterrâneas no Estado do Rio Grande do Norte. In: VAGELER et alii. Levantamento agrogeo Iögico do Estado. Natal, Depto. de Imprensa. p.103-118i1.

WARING, G.A. 1982. Suprimento d'ägua no nordeste do Brasil. 4ed. Mossoró, Centro de Estudos e Debates Presidente Café Filho/ Escola Superior de Agricultura Mossoró. (Coleção Mossoroense, 199). 